Mass Communication and Journalism in the Pacific Islands: A Bibliography

Compiled by

Jim Richstad and Michael McMillan 
THE EAST-WEST CENTER-officially known as the Center for Cultural and Technical Interchange Between East and West-is a national educational institution established in Hawaii by the U.S. Congress in 1960 to promote better relations and understanding between the United States and the nations of Asia and the Pacific through cooperative study, training, and research. The Center is administered by a public, nonprofit corporation whose international Board of Governors consists of distinguished scholars, business leaders, and public servants.

Each year more than 1,500 men and women from many nations and cultures participate in Center programs that seek cooperative solutions to problems of mutual consequence to East and West. Working with the Center's multidisciplinary and multicultural staff, participants include visiting scholars and researchers; leaders and professionals from the academic, government, and business communities; and graduate degree students, most of whom are enrolled at the University of Hawaii. For each Center participant from the United States, two participants are sought from the Asian and Pacific area.

Center programs are conducted by institutes addressing problems of communication, culture learning, environment and policy, population, and resource systems. A limited number of "open" grants are available to degree scholars and research fellows whose academic interests are not encompassed by institute programs.

The U.S. Congress provides basic funding for Center programs and a variety of awards to participants. Because of the cooperative nature of Center programs, financial support and cost-sharing are also provided by Asian and Pacific governments, regional agencies, private enterprise and foundations. The Center is on land adjacent to and provided by the University of Hawaii.

East-West Center Books are published by The University Press of Hawaii to further the Center's aims and programs. 


\section{Mass Communication and Journalism in the Pacific Islands: A Bibliography}





\title{
Mass Communication and Journalism in the Pacific Islands: A Bibliography
}

\author{
Compiled by \\ JIM RICHSTAD and MICHAEL MCMILLAN \\ with the assistance of \\ JACKIE BOWEN
}

₹ An East-West Center Book

from the East-West Communication Institute

Published for the East-West Center by

The University Press of Hawaii, Honolulu 
Copyright (c) 1978 by East-West Center

All rights reserved.

Manufactured in the United States of America

\section{Library of Congress Cataloging in Publication Data}

Richstad, Jim.

Mass communication and journalism in the Pacific Islands: A bibliography

“An East-West Center book."

Includes index.

1. Mass media-Islands of the Pacific-Bibliography.

2. Press-Islands of the Pacific-Bibliography.

I. McMillan, Michael, joint author. II. Title.

P92.I78R5 016.30116'1 77-20695

ISBN 0-8248-0497-X 


\section{CONTENTS}

INTRODUCTION

xiii

Some Trends in the Bibliography

The Development of the Bibliography

xix

Organization of the Volume

Island Groups Included in the Bibliography

xxiii

Structure/Outline of Each Island Group's Chapter

Sources of Entries

List of Abbreviations

xxxii

Acknowledgments

xxxiii

Pacific Islands General

Indexes, Guides, Reference Works

Newspapers, Periodicals

Biographies

Cinema

Communication Research

Education and Training of Communicators

Educational Media

Freedom of the Press/Broadcasting

Government Information Activities

News Agencies

The Press

Press/Broadcasting Organizations

Printing

Radio Broadcasting

Satellite Communication 
$\begin{array}{ll}\text { American Samoa } & 28\end{array}$

Newspapers, Periodicals $\quad 28$

Government and International Agency Reports $\quad 29$

Communication Research $\quad 30$

Education and Training of Communicators $\quad 30$

$\begin{array}{ll}\text { Educational Media } & 30\end{array}$

Freedom of the Press/Broadcasting $\quad 35$

Government Information Activities $\quad 36$

$\begin{array}{ll}\text { Legal Issues } & 37\end{array}$

$\begin{array}{ll}\text { The Press } & 38\end{array}$

Radio Broadcasting $\quad 41$

Satellite Communication $\quad 41$

$\begin{array}{ll}\text { Television } & 42\end{array}$

$\begin{array}{ll}\text { CoOK IsLaNDS } & 43\end{array}$

Indexes, Guides, Reference Works $\quad 43$

Newspapers, Periodicals $\quad 43$

Government and International Agency Reports $\quad 43$

Education and Training of Communicators $\quad 44$

Educational Media $\quad 44$

The Press $\quad 44$

Radio Broadcasting $\quad 46$

Satellite Communication $\quad 47$

$\begin{array}{ll}\text { Television } & 47\end{array}$

$\begin{array}{ll}\text { EASTER ISLAND } & 48\end{array}$

$\begin{array}{ll}\text { Television } & 48\end{array}$

FIJI $\quad 49$

Indexes, Guides, Reference Works

Newspapers, Periodicals $\quad 50$

Government and International Agency Reports 53

Cinema $\quad 53$

Communication Research $\quad 53$

Education and Training of Communicators 54

Educational Media $\quad 55$

Freedom of the Press/Broadcasting 55

Government Information Activities $\quad 56$

Legal Issues $\quad 56$

News Agencies $\quad 57$

The Press $\quad 57$

$\begin{array}{ll}\text { Press/Broadcasting Organizations } & 63\end{array}$

$\begin{array}{ll}\text { Printing } & 63\end{array}$

Radio Broadcasting $\quad 63$

$\begin{array}{ll}\text { Satellite Communication } & 69\end{array}$

$\begin{array}{ll}\text { Television } & 70\end{array}$ 
French Polynesia

Indexes, Guides, Reference Works $\quad 72$

Newspapers, Periodicals $\quad 72$

$\begin{array}{ll}\text { Cinema } & 77\end{array}$

Education and Training of Communicators $\quad 77$

Freedom of the Press/Broadcasting $\quad 77$

$\begin{array}{ll}\text { The Press } & 77\end{array}$

Printing $\quad 79$

$\begin{array}{ll}\text { Radio Broadcasting } & 79\end{array}$

Satellite Communication $\quad 80$

$\begin{array}{ll}\text { Television } & 80\end{array}$

$\begin{array}{ll}\text { GILBERT ISLANDS } & 81\end{array}$

Newspapers, Periodicals $\quad 81$

Government and International Agency Reports 82

$\begin{array}{ll}\text { Cinema } & 82\end{array}$

Education and Training of Communicators $\quad 82$

Government Information Activities $\quad 82$

The Press $\quad 83$

Radio Broadcasting $\quad 83$

Satellite Communication $\quad 83$

GuAM $\quad 84$

Indexes, Guides, Reference Works $\quad 84$

Newspapers, Periodicals $\quad 84$

Cinema $\quad 86$

Education and Training of Communicators $\quad 86$

$\begin{array}{ll}\text { Educational Media } & 87\end{array}$

Freedom of the Press/Broadcasting $\quad 87$

$\begin{array}{ll}\text { The Press } & 87\end{array}$

Printing $\quad 92$

Radio Broadcasting $\quad 92$

Satellite Communication $\quad 93$

Television $\quad 94$

HawaII $\quad 95$

Indexes, Guides, Reference Works 95

Newspapers, Periodicals $\quad 97$

$\begin{array}{ll}\text { Biographies } & 110\end{array}$

Cinema $\quad 111$

Communication Research $\quad 112$

Education and Training of Communicators $\quad 114$

Educational Media $\quad 115$

Freedom of the Press/Broadcasting 120

Labor Relations $\quad 124$

Legal Issues $\quad 127$ 
$\begin{array}{ll}\text { News Agencies } & 130\end{array}$

The Press 130

$\begin{array}{lr}\text { Press/Broadcasting Organizations } & 159\end{array}$

Printing $\quad 162$

Radio Broadcasting 166

$\begin{array}{ll}\text { Satellite Communication } & 174\end{array}$

$\begin{array}{ll}\text { Television } & 178\end{array}$

JOHNSTON ISLAND 192

Newspapers 192

Radio Broadcasting $\quad 192$

MidWay IsLaNd 193

Television 193

NAURU 194

Newspapers, Periodicals $\quad 194$

Freedom of the Press/Broadcasting 194

The Press 194

Radio Broadcasting 195

New Caledonia 196

Indexes, Guides, Reference Works 196

Newspapers, Periodicals $\quad 196$

$\begin{array}{ll}\text { Cinema } & 198\end{array}$

Legal Issues $\quad 198$

The Press 198

Radio Broadcasting 199

Satellite Communication $\quad 199$

Television 200

New Hebrides 201

Indexes, Guides, Reference Works 201

Newspapers, Periodicals 201

Government and International Agency Reports 202

Cinema 202

The Press 203

Printing 203

Radio Broadcasting 203

Satellite Communication 204

NIUE 205

Newspapers, Periodicals 205

Cinema 205

Communication Research 205

Educational Media 206

Government Information Activities 206 
Radio Broadcasting 206

Satellite Communication $\quad 206$

Television 206

NORFOLK ISLAND 207

Newspapers, Periodicals $\quad 207$

The Press 208

Radio Broadcasting 208

Satellite Communication $\quad 209$

$\begin{array}{ll}\text { Television } & 209\end{array}$

OCEAN IsLAND $\quad 210$

Newspapers, Periodicals $\quad 210$

The Press 210

Papua New Guinea $\quad 211$

Indexes, Guides, Reference Works 211

Biographies 211

Newspapers, Periodicals 211

Government and International Agency Reports 215

$\begin{array}{ll}\text { Cinema } & 216\end{array}$

Communication Research 217

Education and Training of Communicators $\quad 219$

Educational Media $\quad 220$

Freedom of the Press/Broadcasting 221

Government Information Activities 223

The Press 224

Press/Broadcasting Organizations $\quad 233$

Printing 234

Radio Broadcasting $\quad 234$

Satellite Communication $\quad 241$

Television 242

PItCAIRN $\quad 243$

Newspapers, Periodicals 243

The Press 243

Radio Broadcasting 243

SOLOMON ISLANDS $\quad 244$

Indexes, Guides, Reference Works $\quad 244$

Newspapers, Periodicals $\quad 244$

Government and International Agency Reports 245

Cinema $\quad 245$

Communication Research 245

Education and Training of Communicators $\quad 245$

Educational Media $\quad 246$ 
Freedom of the Press/Broadcasting 246

The Press $\quad 246$

Printing 247

Radio Broadcasting 247

TONGA $\quad 249$

Newspapers, Periodicals $\quad 249$

Cinema $\quad 250$

Communication Research 250

Education and Training of Communicators 250

Educational Media $\quad 250$

Freedom of the Press/Broadcasting 250

Legal Issues $\quad 251$

The Press 251

Radio Broadcasting 253

Satellite Communication 255

Television 255

Trust Territory OF THe Pacific Islands (Micronesia) 256

Indexes, Guides, Reference Works 256

Newspapers, Periodicals 257

Government and International Agency Reports $\quad 260$

Cinema 260

Communication Research 260

Education and Training of Communicators 261

Educational Media $\quad 261$

Freedom of the Press/Broadcasting 262

Government Information Activities $\quad 262$

News Agencies $\quad 262$

The Press 263

Press/Broadcasting Organizations $\quad 266$

Printing 266

Radio Broadcasting 266

Satellite Communication $\quad 268$

$\begin{array}{ll}\text { Television } & 269\end{array}$

$\begin{array}{ll}\text { Tuvalu } & 270\end{array}$

Newspapers, Periodicals $\quad 270$

Government and International Agency Reports 271

Education and Training of Communicators 271

Government Information Activities 271

Radio Broadcasting 271

Satellite Communication $\quad 272$

WALLIS AND FUTUNA ISLANDS $\quad 273$

Newspapers, Periodicals $\quad 273$ 
Printing

Radio Broadcasting 273

WESTERN SAMOA $\quad 274$

Newspapers, Periodicals $\quad 274$

Government and International Agency Reports 275

$\begin{array}{ll}\text { Cinema } & 275\end{array}$

Communication Research 276

Education and Training of Communicators 276

$\begin{array}{ll}\text { Educational Media } & 277\end{array}$

Freedom of the Press/Broadcasting 278

$\begin{array}{ll}\text { Legal Issues } & 279\end{array}$

$\begin{array}{ll}\text { The Press } & 279\end{array}$

Printing $\quad 282$

Radio Broadcasting 283

Television 284

$\begin{array}{ll}\text { INDEX } & 285\end{array}$ 



\section{INTRODUCTION}

The history of mass communication and journalism in the Pacific Islands is yet to be written. Parts of the story are scattered more widely than the Pacific Ocean itself, in hundreds of journals, newspapers, reports, magazines and books. Other parts exist in the memories of the still active pioneers in Pacific mass communication and journalism.

In beginning to look for the story, one is faced with a formidable task of searching out the published materials. To make that task easier, and to show the wide range of materials available on Pacific communication, the East-West Communication Institute undertook this bibliographic project. The project was undertaken when, in the course of our research and training work at the Communication Institute, we discovered the lack of even preliminary bibliographic work. It was readily apparent that a bibliography was urgently needed, and the project was undertaken to meet our needs and aid the work of others. It has been a slow and tedious task, as bibliographers will understand. And it is not complete-there are perhaps many other citations that could be added to this collection. In looking through Mass Communication and Journalism in the Pacific Islands: $A$ Bibliography, one has a strong sense of dynamism and change in communication in the islands. The history exists in skeletal form, in the numerous entries of this bibliography-for here are recorded the beginnings of publications, of radio broadcasts, of newspapers, of television, of film, of underwater cables, and of communication satellites. It remains for students and scholars and others to assemble the "bones" as best they can. This bibliography was developed to encourage the individual exploration of mass communication and journalism in the Pacific and at least to begin to write the history. 



\section{SOME TRENDS IN THE BIBLIOGRAPHY}

The bibliography covers the period from 1854 to the end of 1975 , with readily available entries collected into most of 1976. As we see it, one of the values of this collection is that it identifies many of the gaps in our knowledge of communication and journalism in the Pacific. These gaps are evident even in a cursory glance through the citations.

The bibliography clearly indicates that this is a time for a bringing together, a synthesis, of many areas. Libel, for example, is the topic in a few entries here and there in the bibliography but nowhere is there a thoughtful, serious and comprehensive article on libel and other legal issues involving the mass media. There is no article that places the practical experiences of the press and other mass media within the broader perspective of the different legal systems that have shaped such legal issues as libel, defamation of character and obscenity. And finally, there is nothing written on how these legal issues have been adapted to the Pacific way of doing things. There is obviously a great deal of interest and a real need for such a study; the bibliography both points up that need and provides the important first references for such an article. There are many other examples where important work is obviously needed.

One striking factor apparent in the citations is the extent of television development in the Pacific Islands. Television is often talked about as something yet "to come" to the Pacific, and not something that is already there (with the exceptions of the American and French areas). Television was introduced in Hawaii and Guam in the mid-1950s, in New Caledonia, Tahiti and American Samoa in the mid-1960s, and in Micronesia in the early 1970s. While it is true that those are the places where television is established, there are numerous references to television going back many years, with the first bibliography entry in 1932. Not long ago, for example, broadcast television was introduced to Easter Island. Experimental or closedcircuit television is being or has been used in Papua New Guinea and Fiji. Video tape recorders (VTRs) are in use in several areas where broadcast television itself is not 
present. A television station started on Midway, the bibliography notes. Both Tonga and Niue recently had proposals for cable television. Western Samoa regularly receives television broadcasts from American Samoa, and different places in the Pacific get in on freakish television reception from distant areas, due to weather idiosyncrasies.

Consideration was given in early 1976 to offering complete television stations, made idle under cutbacks in programming in American Samoa, to other countries in the Pacific, such as Western Samoa and Tonga. Note that Western Samoa, without a television station of its own, has more television receivers than does American Samoa, where the television station is located. In 1976, a monthly newsletter from the Wallis and Futuna islands was seriously presenting the possibility of satellite television but noted the cost was too high for the small islands. Ian Johnstone, a long-time figure in broadcasting in the Pacific Islands and New Zealand, proposed in 1973 the introduction of VTRs before open broadcasting is introduced, so that Pacific Islanders could get experience in such areas as program content, equipment and technical skills before the advent of open television broadcasting. Television, with its expenses, problems and promises, is likely to increase in importance, with Pacific Islanders studying its possibilities and deciding what should and can be done.

The Pacific Islands, then, can no longer be thought of as relatively "unspoiled" by television. Television has become a factor in the mass communication and journalism picture of the Pacific Islands, yet there is not a comprehensive account of this development.

One area of television that has received detailed attention in reports and articles has been the educational television programming in American Samoa that began in 1962. This ETV experience can be a valuable lesson to other Pacific Islands that are considering the introduction of educational television or even general television. The many citations on the American Samoan experience readily illustrate the differences of opinion between political leaders and educators, and among educators themselves, on the value of such a television system. There are many excellent accounts and analyses of the development, as noted in the bibliography, with a comprehensive evaluation under preparation in 1977 by Dr. Wilbur Schramm and others.

Another modern medium-the communication satellite-is also making its mark rapidly on the Pacific Islands. In six years since its initiation in Hawaii in 1971, the PEACESAT radio system has pioneered in low-cost, two-way, interactive satellite communication; in 1974 the University of the South Pacific began its international extension service, utilizing the same ATS-1 satellite and some of the same terminals. In just a few years, the satellite, with its capacity to transmit over great distance, has given 14 nations and territories in the Pacific Islands instantaneous communication. ATS-1 has the capacity to cover the entire Pacific Ocean and most of the U.S. Mainland and Alaska. The wide range of uses of the two overlapping satellite systems is described in the reports, articles, and other publications just beginning to appear in significant numbers, as the bibliography testifies. There are, of course, many more developments ahead for satellite communication in the Pacific, and more analyses and evaluations coming for PEACESAT and the USP Satellite Extension 
program. The potential for satellite communication in the Pacific is tremendous, but the costs involved to the individual countries for conventional or established satellite service are great without some kind of subsidy and united action. In early 1977, a demonstration project for ATS-6, the television satellite, was under consideration for the South Pacific. The novel aspect of the PEACESAT system, significant far beyond the Pacific area it services, is that it shows the way for low-cost, user-control of one of the most modern means of communication, which in other contexts is a highly centralized, heavy-user controlled, high-cost medium. Hundreds of people each year are routinely talking to each other over PEACESAT across thousands of miles of ocean, utilizing the satellite for a wide range of social purposes. It is an experience without parallel in the rest of the world, and there is a good deal more to learn about it.

Another important finding from this bibliographic study is the relative absence of articles, studies or reports dealing with cinema in the Pacific Islands, either currently or historically. The impact of "the movies" on the Islands has been great. Movies were the first mass medium in the Islands, and still the only visual medium in most areas. And it continues strong in both pre-television and television societies. Yet the few references to cinema deal largely with such things as censorship of sex and violence, with little attention given to the broader sociological implications of the introduction of foreign cultural styles into the traditional cultures of the Pacific. Cinema in the Pacific has a long history but has yet to receive the kind of serious and sustained attention it deserves. Many Pacific Islanders today are rightly concerned about the introduction of television and satellite communication into their cultures, yet we have an unexamined historical record to study on the introduction of a similar medium, cinema. Such a study could provide some insights on the effects of the introduction of television.*

Theoretical studies and reports of systematic research on communication in the Pacific Islands are scarce, although there is increasing activity in such places as Papua New Guinea and in Hawaii.

Another serious gap in the literature is a lack of a comprehensive account of the development of the newspaper press in the Pacific Islands. There is no history of the press in print, although at least one manuscript has been written. And the same is true for broadcasting in the Pacific-there is no comprehensive account on broadcasting development, although it is recognized that radio broadcasting is the only true mass medium in the Pacific. Ian Johnstone's 1976 overview of broadcasting (see Communication in the Pacific, Lerner and Richstad, editors) is the best of what's available but more lengthy treatment is needed. There is almost a complete absence of serious biography of the leaders of Pacific mass communication and journalism,

\footnotetext{
*As a beginning to broader cinema studies, Floyd $\mathrm{K}$. Takeuchi of the East-West Communication Institute undertook in 1976 a five-month study of the flow of movies in the Pacific, censorship policies and activities, seating capacities and theater-owners' views on audience preferences. His findings were not ready in time for inclusion in this bibliography but they should be an important milestone in the study of cinema in the Pacific. The citation is "A Status Study of Commercial Cinema in the Pacific Islands," M.A. thesis, University of Hawaii, 1977.
} 
with the exception of Hawaii. Without perceptive studies of the newspaper men and women who have set the basic foundations of the press and broadcasting, it will be difficult to trace how the Pacific Islanders took the European traditions and practices of journalism and moved them toward a still-evolving "Pacific style" of journalism.

Some developments over the past several years promise to add significantly to our knowledge of mass communication and journalism. The East-West Communication Institute, established at the East-West Center in Honolulu in 1970, specializes in mass communication in the Pacific Islands, among its several interests. The first meeting of South Pacific newspaper editors was held in 1972 in Suva, Fiji, and a broader meeting that included broadcasting and government information officers was held in 1974, also in Suva. At the second meeting, the Pacific Islands News Association (PINA), the first Pacific-wide professional mass communication organization, was founded to promote training and to advance the profession of journalism. The ATS-1 system developed during this period.

Unesco inaugurated a broadcast training center in Apia, Western Samoa in 1975, and in the same year training and study programs in journalism and communication were begun at the University of Papua New Guinea and the University of Guam. (The University of Hawaii was until then the only Pacific Island university with programs in journalism and communication.) 


\section{THE DEVELOPMENT OF THE BIBLIOGRAPHY}

One of the difficulties of bibliographic work in mass communication and journalism in the Pacific Islands is that not much of substance has been written specifically on the subject. There has been little research on mass communication and journalism until recently. There have been a few "histories of the press" in various parts of the Pacific, and there is at least one finished manuscript of Pacific-wide press history.

In searching the various standard bibliographies and other reference books, and the professional and research journals, one is struck by how very little attention has been paid to mass communication and journalism developments in the Pacific Islands, yet it is an area that has both a colorful and an important communication story to tell.

This general lack of materials of all kinds concerning mass communication and the press affected the approach of the compilers. There is a great reliance on newspapers and general circulation periodicals, for example. While most bibliographies would carry only selective and critically needed newspaper citations, we found it was essential to include a great deal of this type of material to present a full bibliographic story-or at least as full as now seems possible.

By far the most faithful chronicler of mass communication and journalism in the Pacific, and most other subjects concerning the Pacific Islands, has been PIM (the Pacific Islands Monthly). Consequently, the most important single source for this bibliography has been PIM. In recent years, the Pacific Islands Communication Newsletter (PICN), coming out quarterly, has been adding further information to what we know. The East-West Center's Communication Institute founded and published PICN from 1970 to mid-1975; since then, the publication has been a joint undertaking of PINA, the Social Sciences and Linguistics Institute of the University of Hawaii and the E-W Communication Institute. Most of the other sources of information on the Pacific either show an occasional interest or a specialized interest. The Asia-Pacific Broadcasting Union, through its $A B U$ Newsletter, systematically 
treats the various broadcasting services in the Pacific that are affiliated with it. The South Pacific Bulletin is a regular supplier of articles about communication, among many other topics. This bulletin is published by the South Pacific Commission, which has for years maintained an active communication training program out of Suva.

This bibliography is the second "foundation" document in mass communication and journalism under the Communication Institute's Pacific Islands communication research program. The first is The Pacific Islands Press: A Directory, an East-West Center book published by The University Press of Hawaii in 1973. It is the first full listing of the newspapers of the Pacific Islands, giving details on staff, frequency of publication, circulation, advertising rates, equipment, and other matters. An expansion and updating of the Directory, to include broadcasting and cinema, was begun in mid-1976. There have been other reports, papers, and materials relating to Pacific communication that have been produced at the Communication Institute over the years. Several communication training programs were conducted there from 1970 to 1973, and conferences on "Users of PEACESAT" and "Communication in the Pacific" were held in 1975, with a resulting publication, Communication in the Pacific, in 1976. A "Flow of News" study of Pacific Island newspapers was underway in late 1976. 


\section{ORGANIZATION OF THE VOLUME}

The general arrangement of the bibliography is simple, partly because of the nature of the materials themselves. The volume is arranged alphabetically by island groupings or more accurately, by national and territorial groupings; each group has alphabetically arranged subject headings within it; within each subject heading items are arranged chronologically. There are a few exceptions to this organizationalphabetical listings by author or title (where available) are used in each national grouping for Indexes, Guides, Reference Works; Newspapers, Periodicals; Biographies; and Government and International Agency Reports. In these entries, particular reference materials can be found more easily with alphabetical presentation. The use of chronological listings for all other sections provides a quick reference to major events in each Pacific area's mass communication history-the story as it developed. Thus, one can see where the first entries on, say, television, occur in relation to other mass communication developments, or when satellite communication is first discussed, and so on. Reading the chronological entries in itself gives a good impression of the development of mass communication, its problems, and leading figures, and provides handy references for comparisons between island groups.

General entries that cover all or most of the Pacific are found in the Pacific Islands General section, and, unless one is of particular importance to an island grouping, it is not repeated in more specific sections. 



\section{ISLAND GROUPS INCLUDED IN THE BIBLIOGRAPHY}

Some administrative or national boundaries have changed during the time this bibliography was being developed. The Ellice Islands, for example, separated from the Gilberts in October 1975 and became Tuvalu, with full separation in January 1976. All early reference materials that included information on both the Gilbert \& Ellice Islands have been included in each group's chapter. All information concerning the different districts in Micronesia has remained together, however, despite ongoing political changes.

Pacific Islands General
American Samoa
Cook Islands
Easter Island
Fiji
French Polynesia
Gilbert Islands
Guam
Hawaii
Johnston Island
Midway Island
Nauru
New Caledonia

Pacific Islands General

American Samoa

Easter Island

Fiji

Gilbert Islands

Johnston Island

Midway Island

Nauru

New Caledonia

\author{
New Hebrides \\ Niue \\ Norfolk Island \\ Ocean Island \\ Papua New Guinea \\ Pitcairn Island \\ Solomon Islands \\ Tonga \\ Trust Territory of the \\ Pacific Islands (Micronesia) \\ Tuvalu \\ Wallis \& Futuna Islands \\ Western Samoa
}





\title{
STRUCTURE/OUTLINE OF EACH ISLAND GROUP'S CHAPTER
}

The categories chosen for this bibliography do not have distinct margins. For example, the categories Freedom of the Press/Broadcasting and Legal Issues are closely related. For this bibliography, the category Legal Issues includes libel actions, punitive damage cases and other suits before the legal authorities. The category Freedom of the Press/Broadcasting includes more generalized issues, such as constitutional definitions of freedom of the press, access to news media, freedom of information issues, and a more recently emerging issue-the right to communicate.

Hawaii's chapter includes citations in all categories, due mainly to a fully developed mass media system and easier access to relevant reference sources. For some island groups, full information was not available to us, while for other island groups many of the categories were not relevant.

Citations in the first four categories listed below were arranged alphabetically since many reports or reference works are updated periodically. This has been noted in the original citation alone. The remaining categories have citations listed chronologically so that the reader may gauge historical events easily.

\author{
INDEXES, GUIDES, REFERENCE WORKS \\ NEWSPAPERS, PERIODICALS \\ BIOGRAPHIES \\ GOVERNMENT \& INTERNATIONAL AGENCY REPORTS \\ CINEMA \\ COMMUNICATION RESEARCH \\ EDUCATION AND TRAINING OF COMMUNICATORS \\ EDUCATIONAL MEDIA \\ Newspapers \\ Radio
}




\section{Television}

Documents, Studies, Reports

Journal Articles

Newspaper and Magazine Articles

FREEDOM OF THE PRESS/BROADCASTING

GOVERNMENT INFORMATION ACTIVITIES

LABOR RELATIONS

LEGAL ISSUES

NEWS AGENCIES

THE PRESS

General

Specific Newspaper or Journal (alphabetically ordered)

PRESS/BROADCASTING ORGANIZATIONS

PRESS COUNCILS

PRINTING

RADIO BROADCASTING

General

Foreign-Language Broadcasting

Specific Radio Station Call Letters (alphabetically ordered) SATELLITE COMMUNICATION

TELEVISION

General

Cable

Foreign-Language Broadcasting

Specific Television Station Call Letters (alphabetically ordered) 


\section{SOURCES OF ENTRIES}

In searching entries, the compilers relied primarily on materials presently available in Hawaii, particularly in the libraries of the University of Hawaii, which specializes in the Pacific Islands generally, and in the Resource Materials Collection of the EastWest Communication Institute at the East-West Center. The Communication Institute, as noted, is active in study and research in Pacific Islands communication, and the Resource Materials Collection houses the papers, reports, and other materials gathered for and generated by those activities. Significant material was obtained through travels, visitors, and correspondence. Further entries were provided by several "in-country" reviewers, who also helped clear up inconsistencies, eliminated duplications, and greatly increased the accuracy and relevance of the entries. Opportunities arose for quick examination of the Library of Congress and British Museum catalogs and printouts. The Pacific Islands collection at the University of California, Santa Cruz, also was examined.

In addition to library catalogs and published bibliographies and the Micronesian Area Research Files, the following periodicals and journals, except for some issues that were not available, were examined for citations:

\author{
ABU Newsletter \\ Amerika Samoa \\ Audiovisual Instruction \\ Australian External Territories \\ (formerly Australian Territories) \\ Business Periodicals Index \\ Columbia Journalism Review \\ Communication Research \\ Editor \& Publisher
}

Educational and Industrial Television (formerly Educational Television)

Educational Broadcasting International (formerly Educational Television International)

Educational Broadcasting Review

Gazette

Glimpses of Guam

Guam Recorder 
Hawaii Bar News

Hawaii Journalism Review

Hawaiian Historical Review

Hawaiian Journal of History

Honolulu Advertiser

Honolulu Star-Bulletin

Impulse

Journal de la Societé des

Océanistes

Journal of Broadcasting

Journal of Communication

Journal of Pacific History

Journal of the Communication

Association of the Pacific

Journal of the Polynesian Society

Journalism Quarterly

Micronesian Reporter

NAEB Journal
New Guinea, Australia, the Pacific and Southeast Asia

New York Times

Overseas Education

Pacific Islands Communication

Newsletter

PIM (Pacific Islands Monthly)

Pacific Perspective

Pacific Profile

Pacific Viewpoint

Papua and New Guinea Society

Public Telecommunication Review

The Quill

South Pacific

South Pacific Bulletin

South Pacific Commission Quarterly News of Activities

Transmitter

The basic bibliographies used were:

Allen, W. J., and I. G. Basset, comp. "A Bibliography of the Cook Islands." Department of Geography, Massey University, 1968.

Allied Forces Southwest Pacific Area. An Annotated Bibliography of the Southwest Pacific and Adjacent Areas, 4 vols. 1945.

"Annotated List of Selected Publications on Papua and New Guinea," Australian Territories, 4, no. 3 (1964): 30-40.

Australia. National Library. The Territory of New Guinea as a Trust Territory. Select Bibliographies, Australian Series no. 4. Canberra: The Library, 1953.

Australian National University. An Ethnographic Bibliography of New Guinea, 3 vols. Canberra: Australian National University Press, 1968.

"Bibliographie de l'Océanie," Journal de la Societé des Océanistes. Annually since 1945.

Cammack, Floyd M., and Shiro Saito. Pacific Island Bibliography. New York: Scarecrow Press, 1962.

Cools, Amerigo. "Additions a la 'Bibliographie de Tahiti' publiee en 1968," Journal de la Societé des Océanistes, 25 (December 1969): 316-20.

Coppell, W. G. "Bibliographies of the Kermadec Islands, Niue, Swains Islands, and the Tokelau Islands." Working Papers no. 2. Honolulu: Pacific Islands Program, University of Hawaii, 1975.

. "Micronesia: A Catalogue of Theses and Dissertations About the Region and Its Constituent Countries and Territories." Unpublished Paper, Mac. quarie University, North Ryde, N.S.W. May 1976. 
Corey, Vickey, comp. Guam. Agana: Nieves M. Flores Memorial Library, 1964.

Draper, Benjamin, ed. Pacific Nations Broadcasting III and Bibliography. San Francisco: Broadcast Industry Conference, San Francisco State University, 1974.

Duprat, Gabrielle, Ksenia Liutova, and Marie-Louise Bossuat. Bibliographie des repertoires nationaux de periodiques en cours. Paris: Federation internationale des associates de bibliothecaires (IFLA-FIIAB)/UNESCO, 1969.

Ferguson, John A. A Bibliography of the New Hebrides and a History of the Mission Press, 3 vols. Sydney: privately printed, 1917, 1918, 1943.

Gardner, Arthur L. The Koreans in Hawaii: An Annotated Bibliography. Honolulu: Social Science Research Institute, 1970.

Griffin, A.P.C., comp. List of Books Relating to Hawaii, Including References to Collected Works and Periodicals. Washington: Government Printing Office, 1898.

Gwyther-Jones, Roy E. Literature for a New Nation (Ol Buk Bilong Papua Nu Gini). Ukarumpa, Papua New Guinea: Summer Institute of Linguistics, 1972.

Hawaii Library Association. Hawaiiana Section, comp. Official Publications of the Territory of Hawaii, 1900-1954. Honolulu: Public Archives, Department of Accounting and General Services, State of Hawaii, 1962. 250 pp.

Hunnewell, James. Bibliography of the Hawaiian Islands. Boston: A.A. Kingman, 1869.

Kunz, E. F., comp. An Annotated Bibliography of the Languages of the Gilbert Islands, Ellice Islands, and Nauru. Sydney: Trustees of the Public Library of New South Wales, 1959.

Leeson, Ida. A Bibliography of Bibliographies of the South Pacific. London: Oxford University Press, 1954.

Lichty, Lawrence C., comp. World and International Broadcasting: A Bibliography. Washington: Association for Professional Broadcasting Education, 1970.

Lowe, C. H. (Lo Ch'uan-hua). The Chinese in Hawaii: A Bibliographic Survey. Taipei: China Printing Co., 1972. 148 pp.

Historical sketch, chronology, and selected and annotated bibliography.

Matsuda, Mitsugu. The Japanese in Hawaii, 1868-1967: A Bibliograpy of the First Hundred Years. Honolulu: Social Science Research Institute, 1968.

The Japanese in Hawaii: An Annotated Bibliography of Japanese Americans. Hawaii Series no. 5. Revised by Dennis W. Ogawa with Jerry Y. Fujioka. Honolulu: Social Science Research Institute, 1975.

McGrath, William A. New Guineana or Books of New Guinea 1942-1965: A Bibliography of Books Printed Between 1942-1964 Relating to the Territory of Papua and New Guinea. Sydney: Margaret Woodhouse Bookshop, 1965.

Morris, Nancy, Verna Young, Kehau Kahapea, and Velda Yamanaka, comp. "Preliminary Bibliography of Hawaiian Language Materials at the University of Hawaii, Manoa Campus." May 1973.

New York (City). Emergency Relief Bureau. American Samoa. 193 ? 
O'Reilly, Patrick, and Édouard Reitman. Bibliographie de Tahiti et de la Polynésie Française. Publications de la Societé des Océanistes, no. 14. Paris: Musée de l'Homme, 1967.

O'Reilly, Patrick, and Hugh Laracy. "Bibliographie des Presses de la Mission Mariste des Iles Salomon du Nord," Journal de la Societé des Océanistes, 27 (December 1971): 367-86.

O'Reilly, Patrick. "Bibliographie des Presses de la Mission Mariste des Iles Salomon Méridionales," Journal de la Societé des Océanistes, 25 (December 1969): 257-92.

Bibliographie des Nouvelles Hébrides. Publications de la Societé des Océanistes, no. 8. Paris: Musée de l'Homme, 1958.

Bibliographie Méthodique, Analytique et Critique de la NouvelleCalédonie. Publications de la Societé des Océanistes, no. 4. Paris: Musée de l'Homme, 1955.

Bibliographie Méthodique, Analytique et Critique des Iles Wallis et Futuna. Publications de la Societé des Océanistes no. 13. Paris: Musée de l'Homme, 1965. Also appears in Journal de la Societé des Océanistes, 20 (1963): 229-96.

Imprints of the Fiji Catholic Mission including the Loreto Press, 1864-1954. London: Francis Edwards, Ltd., 1958.

Petit essai bibliographique des ouvrages exécutés à Nouméa et à St. Louis et sortis des presses de l'Imprimerie Catholique de la Mission de NouvelleCalédonie, 1885-1939. Paris: Chez l'Auteur, 1951.

“Pacific Bibliography, 1960-1965," Pacific Travel News, 2 (1966): 116-38.

Pacific Islands and Trust Territories: A Select Bibliography. Washington: Department of the Army, 1971.

Papua New Guinea. University. Library. New Guinea Bibliography: A Subject List of Books Published in the New Guinea Area and Books Dealing Wholly or Partially with a New Guinea Subject, Published Overseas. Port Moresby. Annually since 1967.

New Guinea Periodical Index: Guide to Current Periodical Literature About New Guinea. 1968-. First published quarterly, now annually.

Polansky, Patricia. Russian Writings on the South Pacific Area. Honolulu: Pacific Islands Program, University of Hawaii, 1974.

Reeves, Susan C., and May Dudley. "New Guinea Social Science Field Research and Publications," New Guinea Research Bulletin, no. 32. Canberra: New Guinea Research Unit, Australian National University, 1969.

Detailed bibliography listed by district and subject.

Reid, Charles F., comp. Bibliography of the Island of Guam. New York: H. W. Wilson Co., 1939.

Roth, H. O. South Pacific Government Serials: A Select List. Bibliographical Bulletin no. 9. Auckland: Auckland University Library, 1973.

Snow, Philip A. A Bibliography of Fiji, Tonga, and Rotuma, Preliminary Working Edition. Coral Gables: University of Miami Press, 1969. 
Taylor, Clyde R. H. A Pacific Bibliography: Printed Matter Relating to the Native Peoples of Polynesia, Melanesia and Micronesia, 2nd ed. Oxford: Clarendon Press, 1965.

Utinomi, Huzio (Uchinomi, Fujio), comp. Bibliography of Micronesia (Bibliographia Micronesia, Scientiae naturalis et cultus,) Ed. and rev. O. A. Bushnell. Trans. Matsuno Fukuda, et al. Honolulu: University of Hawaii Press, 1952. Originally published in Tokyo, 1944.

United Nations. Trusteeship Council. Select Bibliography and Catalogue of Publications and Maps Relating to Trust Territory in the Pacific. 1952.

United States. Works Projects Administration. New York (City). Classified Bibliography of American Samoa. 1942.

University of Hawaii Pacific Urban Studies and Planning Program, comp. Asia and Pacific Planning Bibliography, vol. 1-5 (January 1971-March 1974). Montecello, Illinois: Council of Planning Librarians.

Vickery, William. "Bibliography of Palau." Honolulu, 1960. Typescript in the Pacific Collection, University of Hawaii Library. 4 pp.

Wedgewood, Camilla H. Education in the Pacific Islands: A Selective Bibliography. Technical Paper no. 99. Noumea: South Pacific Commission, 1956.

Wright, Gordon. A Bibliography of Reports, Surveys, and Studies Prepared By, For, or About the Trust Territory of the Pacific Islands. Union Catalogue Project. Saipan: Department of Education, Trust Territory of the Pacific Islands, 1969.

Young, Nancy F. The Chinese in Hawaii: An Annotated Bibliography. Hawaii Series no. 4. Honolulu: Social Science Research Institute, 1973. 


\title{
ABBREVIATIONS OF FREQUENTLY CITED NEWSPAPERS, JOURNALS OR PERIODICALS
}

\author{
ABU $A B U$ Newsletter \\ ADV Honolulu Advertiser \\ GR Guam Recorder \\ NYT New York Times \\ PICN Pacific Islands Communication \\ Newsletter \\ PIM Pacific Islands Monthly \\ S-B Honolulu Star-Bulletin \\ SBA Sunday Star-Bulletin \& Advertiser \\ SPB South Pacific Bulletin
}




\section{ACKNOWLEDGMENTS}

This project was developed over four years-1972 to 1976-with many persons contributing significantly. Graduate students who assisted in gathering entries include EWC grantees Sandra Carney-Rowan and Floyd Takeuchi. Mary Geilfuss, a student at the University of Hawaii, also assisted. Monica MacLeod did some important final searching and contributed her particular knowledge of Pacific Islands sources.

Renée Heyum, Pacific Curator, Hawaii Pacific Collection, University of Hawaii, reviewed the entire manuscript (except Hawaii) on two occasions and made numerous valuable contributions on form and citations. W. G. Coppell of Macquarie University also reviewed the entire manuscript and made helpful additions. David J. Kittelson, Hawaiian Curator at the University of Hawaii, reviewed the Hawaiian section twice, and Patrick O'Reilly, noted Pacific bibliographer, examined the French Polynesia and New Caledonia parts.

Valuable "in-country" reviews of sections were made by Timai Tekaai of the then Gilbert \& Ellice Islands; Elias H. Thomas, George Callison, Dan Peacock, and Bonifacio Basilius of the government of the Trust Territory of the Pacific Islands (Micronesia); Emilie G. Johnston, Curator, Pacific Collection, University of Guam, Micronesian Area Research Center; Mildred Council, Librarian, Library of American Samoa; Peter B. Orbeton, Gifts and Exchanges Librarian, Library of the University of the South Pacific, Suva, Fiji; G. W. Stevens, Senior Research Officer, Broadcasting Department, British Residency, Vila, New Hebrides; S. T. Fusimalohi, Tonga Broadcasting Commission Manager, and Sione Fonua, TBC program supervisor; R. G. Spooner, Education Officer, Education Department, Government of Niue; Tom Lloyd, Editor-Publisher, Norfolk Islander, Norfolk Island; L. G. Usher, former editor, Fiji Times; Catherine Wallace, New Guinea Collection, Library of the University of Papua New Guinea; Sally M. Edridge, Library Advisor, Ministry of Education and Cultural Affairs, Honiara, Solomon Islands. The reviews were made at various stages of the compilations. 
Sumiye Konoshima, Resource Material Specialist at the E-W Communication Institute, provided valuable guidance on all aspects of the project. Kay Garrett, Publications Officer, saw the manuscript through publication. Phyllis Watanabe prepared the typescript. Special thanks go to Michio Nagai and to Wilbur Schramm, directors of the Communication Institute during the compilation of the bibliography, and to its present Director, Jack Lyle, for seeing the work to publication.

Numerous other people helped-with ideas, citations, suggestions, and encouragement. Any errors or omissions are, of course, the responsibility of the compilers. 


\section{Pacific Islands General}

\section{INDEXES, GUIDES, REFERENCE WORKS}

1 Australian National Commission for Unesco. Source Materials related to Research in the Pacific Area. Canberra: Australian Government Publishing Service, $1973.98 \mathrm{pp}$.

A collection of nine articles dealing with the collection and preservation of Pacific resource materials, some describing specific collections.

2 Cleland, Lindsay. "Australian Archives, Canberra: Some Records relating to the Pacific," Journal of Pacific History, 9 (1974): 164-71.

Descriptive list of some important holdings of the Australian Archives concerning various Pacific Islands areas.

3 Coppell, W. G. "Micronesia: A Catalogue of Theses and Dissertations About the Region and Its Constituent Countries and Territories." Unpublished paper. Macquarie University, North Ryde, N.S.W. May 1976. 21 pp.

Includes works on the U.S. Trust Territory of the Pacific Islands, Caroline Islands, Mariana Islands, Marshall Islands, Guam, Japanese League of Nations mandate, Gilbert and Ellice Islands, and Nauru.

4 Dickson, Diane, and Carol Dossor, comp. World Catalog of Theses on the Pacific Islands. Honolulu: University of Hawaii Press, 1970. $123 \mathrm{pp.}$

Lists theses written prior to June 30, 1968.

5 "A Directory of Libraries and Information Services in Hawaii and the Pacific Islands," Hawaii Library Association Journal, 27, no. 2 (1970). 96 pp. Index.

6 Dornbusch, Charles E., comp. Yank, The Army Weekly. Gordon Lester Ford Memorial Study no. 2. New York: New York Public Library, 1950. 10 pp.

A checklist of files of Yank magazine with an introduction covering background of the publication; some editions were published in Honolulu and later in Saipan for distribution to military forces in the Pacific during World War II. 
7 East-West Communication Institute. Documents Accessions List. Bimonthly since May 1971; published by the resource materials collection of the East-West Communication Institute, East-West Center, Honolulu.

8 "Films and Filmstrip Library: List of Films," SPB, 2, no. 4 (October 1952): 33-36.

Films on the Pacific maintained at the South Pacific Commission Literature Bureau.

9 Foreign Broadcast Information Service. Broadcasting Stations of the World. Washington: Government Printing Office. Published annually since 1946; covers $\mathrm{AM}$ and $\mathrm{FM}$ radio stations and television stations.

10 Great Britain. Colonial Office. Handbook on Broadcasting in the Colonies, 8th ed. London, 1956.

11 Henderson, John W., et al. Area Handbook for Oceania. Washington: Government Printing Office, 1971.

12 Hewitt, Arthur R. Union List of Commonwealth Newspapers in London, $O x$ ford and Cambridge. London: University of London, 1960. $101 \mathrm{pp}$.

13 Index to the Honolulu Advertiser and Honolulu Star-Bulletin. Honolulu: State of Hawaii Department of Education, Office of Library Services, 1929-67 in five volumes; 1968-69 supplement; then annually.

14 Jenkins, D. L. Union List of Theses of the University of New Zealand, 1910-1954. Wellington: New Zealand Library Association, 1956. $282 \mathrm{pp}$.

15 Livesey, Cris, and Owen O'Connor. "List of Pacific Newspapers and Periodicals,"' Spacific: Newsletter of the South Pacific Action Network (SPAN) and the NZusa So. Pacific Officers, 2, no. 2(1972): 5, 6.

Includes Papua New Guinea, Fiji, British Solomon Islands, New Hebrides, Tonga, and the U.S. Trust

Territory of the Pacific Islands.

16 Mander-Jones, Phyllis, ed. Manuscripts in the British Isles Relating to Australia, New Zealand, and the Pacific. Canberra: Australian National University Press, 1972. 697 pp.

17 Marshall, M. J., ed. Union List of Higher Degree Theses in Australian Universities Libraries. Hobart: University of Tasmania Library, 1959. 237 pp. Supplements.

18 Maude, H. E. "Searching for Sources," Journal of Pacific History, 3 (1968): 210-22.

Guide to reference materials for Pacific Islands studies.

19 Mitchell Library. Catalogue of Manuscripts of Australasia and the Pacific in the Mitchell Library, Sydney. Series A. Manuscripts catalogued between 1945 and 1963. Sydney, 1967. 283 pp. Series B. Manuscripts catalogued between 1963 and 1967. Sydney, 1969. 500 pp.

20 Newspapers in Australian Libraries: A Union List, 2nd ed. Canberra: National Library of Australia, 1967. 479 pp. 
21 Pacific Manuscripts Bureau. Guide to Microfilms Supplied by the Pacific Manuscripts Bureau. Canberra: Research School of Pacific Studies, Australian National University, 1968-.

Annotated guide in looseleaf form to the PMB and PMB Document series of manuscripts available from the Pacific Manuscripts Bureau; lists location of original, access conditions, secondary crossreferences, assistance notes.

22 Prakke, Henk, Winfried B. Lerg, and Michael Schmolke. Handbuch der Weltpresse, 2 vols. Koln, Opladen: West-deutscher Verlag, 1970.

Data on press, radio, television, and cinema facilities of various countries with information on press history and press freedom in each.

23 Richstad, Jim, Michael McMillan, and Ralph Barney. The Pacific Islands Press: A Directory. Honolulu: University Press of Hawaii, 1973. 81 pp.

An introductory section describing the state of the press and a list of publications appearing in 1973, with data on facilities and staffs.

24 South Pacific Commission. Index of Social Science Research Theses on the South Pacific. Technical paper no. 102. Noumea: South Pacific Commission, 1957. $79 \mathrm{pp}$.

25 Accessions List. Bimonthly since 1967 by the SPC library. Films and Filmstrip Catalog, rev. ed. Technical paper no. 112. Noumea: South Pacific Commission, 1958.

Catalog of 16-mm and 35-mm films about the South Pacific region; a revision of technical paper no. 71.

27 Service d'appréciation des films et films fixes. Catalogue. Sydney: Social Development Section, South Pacific Commission, 1952. 243 pp.

Films listed by continent; several pages related to the South Pacific.

28 . Literature Bureau. Publications Index: A Guide to the Publications Produced by the Bureau in Cooperation with the Territories in the Region. Noumea: South Pacific Commission, 1963. $28 \mathrm{pp}$.

29 Television Factbook. Washington: Television Digest, Inc. Annually since 1930; title and publisher varied in earlier years.

Contains some information about television stations in the Pacific Islands: ownership; beginning of operations; sales; technical information.

30 Tudor, Judy, ed. Pacific Islands Yearbook, 11 th ed. Sydney: Pacific Publications, 1972. $542 \mathrm{pp}$.

Compilation of economic and social data on all island areas of the Pacific; includes descriptions of mass media in each.

31 Turnbull, Phyllis. Pacific-related Audiovisual Materials for Secondary Schools. Honolulu: Pacific Islands Program, University of Hawaii, 1974. 37 pp.

Lists films, slides, audio tapes related to the Pacific, including material produced by Pacific governments; indicates locations.

32 Unesco. The Daily Press: A Survey of the World Situation in 1952. Reports and Papers on Mass Communication no. 7. Paris: Unesco, 1953. 43 pp. 

Premier Catalogue Sélectif International de Films Ethnographiques sur la Région du Pacifique. Paris: Unesco, 1970. 342 pp.

34 Statistics of Newspapers and Other Periodicals. Statistical Reports and Studies. Paris: Unesco, 1959. 70 pp.

35 . Statistics on Radio and Television. 1959-1960. Paris: Unesco, 1963. $87 \mathrm{pp}$.

36 World Film Directory: Agencies Concerned with Educational, Scientific and Cultural Films. Reports and Papers on Mass Communication no. 35. Paris: Unesco, 1962. $66 \mathrm{pp}$.

37 World Press: Newspapers and News Agencies. Paris: Unesco, 1964. $159 \mathrm{pp}$.

38 World Radio and Television. Paris: Unesco, 1965. 159 pp.

39 World Communications: A 200-Country Survey of Press, Radio, Television, Film. 5th ed. New York: Unipub Press, 1975. 533 pp.

40 United States. Library of Congress. Foreign Newspaper and Gazette Report. Three times a year since 1973 .

Contains information about foreign newspaper acquisitions, microfilming projects, newly available titles, and cooperative microfilming projects.

Newspapers Currently Received \& Permanently Retained in the Library of Congress, rev. ed. Washington: Government Printing Office, 1970. 20 pp.

42

Newspapers in Microform: Foreign Countries, 1948-1972. Washington: Government Printing Office, 1973. $269 \mathrm{pp}$.

43 Newspapers on Microfilm, 6th ed. Washington: Government Printing Office, $1967.487 \mathrm{pp}$.

44 Postwar Foreign Newspapers: A Union List. Washington: Government Printing Office, 1953. $231 \mathrm{pp}$.

45 University of Hawaii. Library. Pacific Collection and Bernice P. Bishop Museum. Acquisition List. Irregularly since 1974.

46 University of the South Pacific. Pacific Collection Accession List. Quarterly since March 1975; supersedes Legal Deposit Accessions.

47 Wolf, G., ed. Encyclopedia Cinematographica, 1952-1972. Gottingen: Institut fur den Wissenschaftlichen Film, 1972. 208 pp. Supplements.

Lists scientific films, mainly German and Swiss with most annotations in English.

48 World Radio-TV Handbook. New York: Billboard Publications. Annually since 1946.

Lists radio and television stations in all countries; brief information on languages used and types of programming. 
NEWSPAPERS, PERIODICALS

49 ABU NEWSLETTER. Sydney. 1965-. Published monthly by Asia-Pacific Broadcasting Union (previously Asian Broadcasting Union).

Regularly carries information on radio and television broadcasting in the Pacific region.

50 ABU TECHNICAL REVIEW. Kuala Lumpur. 1965-. Published monthly by Asia-Pacific Broadcasting Union.

Articles on technical aspects of broadcasting; occasional pieces on the Pacific.

51 HOSTING AND PURCHASING. See South Pacific Islands Business News.

52 NEW GUINEA AND AUSTRALIA, THE PACIFIC AND SOUTH-EAST ASIA. Sydney. March 1965-. Quarterly.

53 PACIFIC ISLANDS COMMUNICATION NEWSLETTER. Honolulu and Suva. 1970-. Irregular, then quarterly. Published by the East-West Communication Institute, Social Sciences and Linguistics Institute, and Pacific Islands News Association.

54 PIM (PACIFIC ISLANDS MONTHLY). Sydney. August 1930-.

55 PACIFIC ISLANDS TRADE NEWS. Auckland, 1969-71; Sydney, 1971-74?

Business news and political articles.

56 PACIFIC TRAVEL NEWS. San Francisco. 1957-. Monthly. Published by Pacific Travel Association.

57 QUARTERLY BULLETIN. See South Pacific Bulletin.

58 RONGO. Wanganui, New Zealand. January 1974-? Only one or two issues, irregularly issued. Published in English and various Pacific Island languages, such as Maori, Samoan, Tongan and Rarotongan.

59 SOUTH PACIFIC. Mosman. 1947-60. Published twice monthly by the Australian School of Pacific Administration.

60 SOUTH PACIFIC ISLANDS BUSINESS NEWS. Suva. August 1975-. Monthly. Supersedes Hosting and Purchasing (May 1973-July 1975), monthly.

61 SOUTH PACIFIC BULLETIN. Noumea. 1951-. Published quarterly by the South Pacific Commission. Originally titled Quarterly Bulletin (1951-1959).

62 SPACIFIC: NEWSLETTER OF THE SOUTH PACIFIC ACTION NETWORK. Wellington, N.Z. 1973-. Monthly. Title varies.

\section{BIOGRAPHIES}

63 O'Reilly, Patrick. "Robert Gibbings (1889-1958) Graveur Anglais et Illustrateur des Livres Polynésiens," Journal de la Société des Océanistes, XIV (1958): 9-21. 


\section{CINEMA}

64 O'Reilly, Patrick. "Le Documentaire ethnographique en Océanie," Journal de la Société des Océanistes. 5 (1949): 117-44.

Analysis and critique of 25 films produced between 1908 and 1948.

65 Halliday, Lex. "How Our Films Can Influence Native Communities," PIM, 20, no. 7 (February 1950): 79, 81-82.

Deals with the introduction of motion pictures into the Pacific Islands for entertainment and education.

66 “Organisation to Supply Pacific with Films," PIM, 21, no. 9 (April 1951): 78.

Reports plans of Metro-Goldwyn-Mayer to create a department to distribute motion pictures in the Pacific region.

67 "Problems of Film Censorship and Radio Broadcasting," PIM, 31, no. 7 (February 1961): 80.

Discusses film censorship and radio broadcasts for native populations.

68 Schmitt, Robert C. "South Sea Movies, 1913-1943," Hawaiian Historical Review, 2, no. 11 (April 1968): 433-52.

Analysis of themes in 132 motion pictures about Hawaii, Melanesia, Micronesia, and Polynesia released in the United States before July 1, 1943.

\section{COMMUNICATION RESEARCH}

69 Mead, Margaret. "Some Cultural Approaches to Communication Problems," Mass Communication, 2nd ed., Wilbur Schramm, ed. Urbana: University of Illinois Press, 1960, pp. 329-345.

First published in 1948, this article reviews three South Pacific Island cultures with different communication systems to illustrate the difficulty of cross-cultural communication and analyzes the problem of debasement of value-symbols in a culture.

70 Lerner, Daniel. "Communication in the Pacific, Prospects for Research." Honolulu: East-West Center, Communication Institute, 1970.

An informal seminar presentation.

71 Barney, Ralph D. "The Mass Media, Their Environment and Prospects in Western Polynesia.” Ph.D. diss., University of Missouri, 1971. 447 pp.

Assesses the capacity for development of Fiji, Tonga, American Samoa, and Western Samoa on the basis of the level and capabilities of development of their mass communication media.

72 "Broadcasting as a Force in Pacific Island Modernization: An Evaluation." Paper prepared for the Conference on International Communication Symposium: Broadcasting in the Pacific, San Francisco State College, San Francisco, April 1972. 13 pp.

Reviews history of broadcasting in Fiji, Tonga, American Samoa, and Western Samoa; stresses importance of broadcasting in the modernization process.

73 "The Press in the Pacific Islands." Paper prepared for the South Pacific Editors' Conference, Suva, July 30-August 5, 1972. Honolulu: East-West Center, Communication Institute, 1972.19 pp.

Deals with the importance of the press in assisting modernization, with statistics from newspapers in four Pacific Islands areas. 
74 Lerner, Daniel, and Jim Richstad. Communication in the Pacific. Honolulu: East-West Center, Communication Institute, $1976.86 \mathrm{pp}$.

Collection of papers from Communication in the Pacific Conference, held in Honolulu in May 1975, focusing on communication and change in the Pacific; organized in three sections: traditional communication modes (Intertribal Communication in Pre-European Times; Music is Communication; Dance in Tonga), changing Pacific profiles (Pacific Politics and Communication; Changing Profile of Population; Changing Language Profiles), and the modern media (Overview of the Pacific Islands Press; News Communication in the Pacific; Broadcasting in the Pacific; PEACESAT: Sharing by Satellite).

\section{EDUCATION AND TRAINING OF COMMUNICATORS}

75 Thompson, R. Educational Aspects of Community Development, Technical Paper no. 74. Noumea: South Pacific Commission, 1955. 98 pp.

A survey of fundamental education in community development as taken from journal articles and other documents; includes a short section on use of films and radio in development.

76 "Communications Training Program," PICN, 2, no. 1 (February 1971): 3.

Information on East-West Center six-week training program in radio journalism and education offered to Pacific Islands broadcasters.

77 Levi, Lavea. "Pacific Island Broadcasters Get Practical Training in Honolulu," $A B U$, no. 74 (June 1971): 28-29.

Report on a six-week radio development seminar; information on the training and participants.

78 “'Broadcast Training Program," PICN, 2, no. 2 (August 1971): 9-11.

Information on training agenda, participants, goals of East-West Center radio broadcasting training for Pacific islanders.

79 “'Open Communication Is Vital," PICN, 3, no. 1 (July 1972): 3.

Needs and methods of communication for agricultural officers.

80 "Editor Talks Direct to Islands," The Dominion (Wellington, New Zealand), May 17, 1973, p. 2.

Reviews satellite conference held by journalists on subject of training program for island journalists. Participants from many Pacific Islands utilized the PEACESAT system.

81 “Agricultural Information and Communication Workshop Planned," PICN, 4, no. 1 (August 1973): 5.

Includes program agenda, objectives, and preliminary list of participants for conference at East-West Center.

82 "Survey on Training for Pacific Island Newspapermen," PICN, 4, no. 1 (August 1973): 1-2.

Results of questionnaires sent to Pacific Islands editors on areas of training, regionalism, shop operations, etc.

83 "Agricultural Information Officers Urge Training," PICN, 4, no. 2 (December 1973): 5.

Article on objectives, training, participants, and results of East-West Center agricultural information and communication workshop.

84 "Radio, TV News Training Discussed on PEACESAT," $P I C N, 4$, no. 2 (December 1973): 5-6.

Deals with training discussions by satellite among parties in New Zealand, Micronesia, Fiji, and Hawaii. 
85 McBain, Norman. "Training in the Pacific,"' $A B U$, no. 100 (January 1974): 27-28.

Report on broadcast training courses sponsored by Unesco and the South Pacific Commission conducted in Fiji and other South Pacific locations in 1973.

86 Cole, Allan V. "Aid for Training." Paper prepared for Pacific Islands News Association Conference, Suva, Fiji. June 27, 1974. 4 pp.

Surveys New Zealand activities in the training of Pacific Islands journalists.

87 “Pacific Journalism Trainees Get Practical Experience," PICN, 4, no. 4 (September 1974): 7.

Discusses journalism education program designed and used by Wellington (N.Z.) Polytechnic Institute and New Zealand Broadcasting Corporation to train broadcast journalism students from the Pacific.

88 “"Training Guidelines Set Up by PINA," PICN, 4, no. 4 (September 1974): 4.

Outline of twelve-point program designed by Pacific Islands News Association for journalism development.

89 “ABU Publishes Training Manual,” PICN, 5, no. 2 (June 1975): 5.

Asian Broadcasting Union published Broadcaster's Reference Manual for use in areas lacking basic training; originally done for Papua New Guinea National Broadcasting Commission.

\section{EDUCATIONAL MEDIA}

90 Williams, J. Grenfell. Radio in Fundamental Education in Underdeveloped Areas. Paris: Unesco, 1950. 152 pp.

Describes how radio fits into the aims of fundamental education; broadcasting techniques and the audience; organization of a broadcasting service; bibliography. Two Pacific Island nations are used as examples of radio development.

91 Goodwin, W. P. "Mass Education in the South Pacific," Oversea Education, 23, no. 1 (October 1951): 186-88.

Describes establishment and early activities of South Pacific Commission with emphasis on publishing of educational materials and some references to study of educational broadcasting.

92 Buick-Constable, L. M. "The History and Use of Radio Education in The Pacific Area," Transactions and Proceedings of The Fiji Society, 8 (1960): 142-44.

Reviews types and benefits of radio techniques in education.

93 South Pacific Commission. Regional Training Seminar on Educational Broadcasting: Report and Recommendations. Noumea: South Pacific Commission, 1970. 105 pp.

Report on a conference at Suva, May 20-June 2, 1970; includes discussion of status of educational broadcasting, recommendations regarding authority and operations, language teaching, use in schools, teacher training, and community education; summarizes papers based on experience in Papua New Guinea, Fiji, and the Cook Islands.

94 De Young, John E. "South Pacific Seminar on Educational Broadcasting," $A B U$, no. 72 (April 1971): 28-30.

Report on a seminar attended by representatives of eight Pacific areas; includes major points and recommendations of the seminar and participant list. 
95 "SPC Workshop Plans for the Teaching of English,"' $A B U$, no. 92 (February 1973): 32.

Report on a January 1973 South Pacific Commission workshop on use of broadcast tapes in teaching English as a second language.

96 Friedman, Bruno, "Satellite is Hub of Pacific-wide Classroom," Unesco Features, no. 657 (1974): 11-13.

Reviews history of PEACESAT project and other educational programs.

97 "Genie in the Sky Links the Pacific," Education News (New Zealand), 2 (March 1976): 11.

Reviews PEACESAT system and its use in education.

\section{FREEDOM OF THE PRESS/BROADCASTING}

98 “Censorship Exchange," PICN, 5, no. 2 (June 1975): 3.

Exchange of letters to editor of Pacific Islands Monthly discusses relation of censorship to community interests.

\section{GOVERNMENT INFORMATION ACTIVITIES}

99 "They Want a Better Press," PIM, 30, no. 4 (November 1959): 53.

Deals with efforts of South Pacific territories to get better publicity, including organization of public relations offices.

100 Fonua, Siosiua H. "Never on Sunday: Advantages and Constraints of Official Media." The Pacific Way: Social Issues in National Development, ed. Siona Tupouniua, et al. Suva: South Pacific Social Sciences Association, 1975, pp. 202-203.

The writer asserts that newspapers must bear the main burden of disseminating cultural and public informational material in the Pacific and that government newspapers must facilitate public participation in development planning by presenting developmental information.

\section{NEWS AGENCIES}

101 Unesco. News Agencies, Their Structure and Operation. Paris: Unesco, 1953; reprinted, New York: Greenwood Press, 1969. 208 pp.

Historical review of news agencies; description and legal organization; telecommunication and transmission of news; international regulations; agencies and radio broadcasting; how the public in various countries receive news. Maps show coverage and facilities in Pacific region.

\section{THE PRESS \\ General}

102 Mills, J. Saxon. The Press and Communications of the Empire. The British Empire, vol. 6. New York: Henry Holt, 1924.

103 "Save This List of Newspapers of South Seas!" $S$ - $B$, February 20, 1937, II-10:1.

Lists, with comments, six newspapers published in Pacific Islands.

104 "Publications About the Pacific," PIM, 17, no. 1 (August 1946): 53.

List of 17 publications issued in Pacific Islands and Australia or frequently containing articles about the islands. 
105 "Press Panic Over Rabaul Earthquake: Legislative Council Censures 'Misleading and Inaccurate' Reports," PIM, 23, no. 10 (May 1953): 20, 117-18.

Story on earthquake at Rabaul contains criticism of newspaper and radio coverage of the situation.

106 "Steady Increase in Pacific Periodicals," SPB, 5, no. 2 (1955): 14, 35.

Notes need for and increase in numbers of local publications; cites several successful publications.

107 Lee, John. "The Expatriate Press: A Survey of English-Language Newspapers Around the World." M.S.J. thesis, West Virginia University, 1965.

108 MacDonald, N. R. "The Daily Press and the Cook Islands, 1945-63." M.A. thesis, Victoria University of Wellington, 1966.

Examines the performance of the New Zealand press, as represented by the New Zealand Herald and the Auckland Journal, in regard to coverage of the Cook Islands; finds their performance unsatisfactory.

109 Grimes, Paul. "Reporting from Abroad." Paper prepared for the South Pacific Editors' Conference, Suva, Fiji, July 30-August 5, 1972. Honolulu: EastWest Center, Communication Institute, 1972.9 pp.

Reviews problem of poor Pacific Islands news coverage in a mainland newspaper, such as The Philadelphia Evening and Sunday Bulletin, on which the author is Director of Foreign News.

110 “Rural Journalism \& Free Press Described," PICN, 3, no. 1 (July 1972): 5.

Emphasizes community needs in Pacific Islands journalism.

111 "Up Front with the Editor," PIM, 45, no. 1 (January 1974): 3.

Professional biography and tribute to departing New York Times Pacific correspondent Robert Trumbull.

112 Toganivalu, Ratu David. "The Press in a Developing Country." Paper prepared for Pacific Islands News Association Conference, Suva, Fiji, June 27, 1974. $9 \mathrm{pp}$.

Essay on importance of understanding between journalists and the government in a developing country, by implication Fiji, where about $\mathbf{4 0}$ per cent of journalists are expatriates, raising the problem of maladjustment to island conditions. The writer asserts press should offer constructive criticism rather than potentially inflammatory statements. He cites need for more organized journalism training.

113 Richstad, Jim, and Michael McMillan. "The Pacific Islands Press," Journalism Quarterly, 51, no. 3 (Autumn 1974): 740-77.

Reviews importance of the press in Pacific Islands development, based on statistics and information developed for larger publication, The Pacific Islands Press: A Directory, by Jim Richstad, Michael McMillan and Ralph D. Barney. Since radio or television, by their nature and historical development, are usually government operations in the South Pacific, or closely related to the government, the newspapers have the responsibility for providing a means of public debate, challenges to government and presentation of strategic alternatives, according to the authors. Statistics of the press in the Pacific, recent trends of the media, and specific characteristics and problems are illustrated.

114 Usher, Leonard G. "The Toddling Newspapers of the Pacific," Media, 1, no. 2 (December 1974): 19, 20.

Article reviews problem of newness of newspaper service in most Pacific Islands and individual newspapers.

115 Wright, Glen. "A Shout of Joy and A Cry of Pain: The Press in the South Pacific," Index on Censorship, 5, no. 4 (Winter 1976): 49-53.

Briefly reviews history of first newspapers published on many Pacific Islands and some of the problems in developing a free press system. 


\section{Australian Territories}

116 “Territories Magazine Is Interesting,” PIM, 31, no. 9 (April 1961): 87.

Review of new monthly magazine, Australian Territories, published by the Department of Territories, Canberra.

\section{Missionary Review}

117 “Jubilee of Missionary Review," PIM, 11, no. 11(June 1941): 64.

Reviews a paper published by Methodist Church of Australasia for over 50 years; paper contains general news of Pacific region as well as religious news.

\section{Oceania}

118 Elkin, A. P. The Journal Oceania: 1930-1970. The Oceania Monographs no. 16. Sydney: University of Sydney, 1970. $39 \mathrm{pp}$.

History of the journal, started in 1929, containing social and cultural anthropology articles.

\section{Pacific American}

119 “New Paper for South Pacific," PICN, 4, no. 1 (August 1973): 3.

Reports plans of Honolulu Star-Bulletin to publish a weekly newspaper, the Pacific American, aimed at North American tourists in the Pacific; includes interview with publisher; information on distribution and editorial policy.

120 "Pacific American Weekly Postponed Until June: To Include Asia Travellers," PICN, 4, no. 2 (December 1973): 3.

Notes proposed circulation, market audience, editorial policy, and printing arrangements for new newspaper.

\section{Pacific Islands Communication Newsletter}

121 “Editorial Introduction," PICN, 1, no. 1 (July 1970): 1-2.

Editorial objectives and purposes of newsletter.

122 “Editor's Notes," PICN, 1, no. 2 (September 1970): 5.

Notes on newsletter's purpose, founding, circulation.

123 “Editor's Note," PICN, 2, no. 1 (February 1971): 8.

Information on publication, objectives, name change of newsletter.

124 “New Home for PICN?” PICN, 4, no. 1 (August 1973): 16.

Newsletter publisher seeks new organization to take over.

125 “Editor's Notes," PICN, 4, no. 4 (September 1974): 3.

Reviews four years of publication of newsletter; change in Pacific Islands communication system.

126 “EWCI Putting Out its Final PICN,” PICN, 5, no. 2 (June 1975): 5.

Final issue of PICN published at the East-West Communication Institute; talks continuing on new publisher.

127 "University Research Institute New PICN Publisher," PICN, 5, no. 3 (September 1975): 2, 3.

Social Sciences and Linguistics Institute, University of Hawaii, agrees to publish PICN for two years in cooperation with East-West Communication Institute and Pacific Islands News Association. 


\section{Pacific Islands Monthly}

128 “PIM Celebrates 17th Birthday,” PIM, 17, no. 12 (July 1947): 8.

Brief background of the growth of the magazine and announcement of plans for regional editions.

129 Robson, R. W. "The Pacific Islands Monthly and its Readers: Editor Discusses the Events of the Last 21 Years," PIM, 21, no. 12 (July 1951): 107-109, 111.

Lengthy comment on the life and times of the magazine, with most emphasis on events.

130 “Four Faces," PIM, 25, no. 12 (July 1955): 5, 7.

Illustrated feature showing the different makeup styles used by Pacific Islands Monthly during its lifetime.

131 Robson, R. W. "Why and How I Established The Pacific Islands Monthly," PIM, 25, no. 12 (July 1955): 4, 38-39.

Describes the origin of the idea for the magazine and the problems associated with its publication through the years; emphasis on business aspects.

132 "Editorship of Pacific Islands Monthly," PIM, 26, no. 8 (March 1956): 18.

Founder and editor of Pacific Islands Monthly, R. W. Robson, spent time in Fiji concerning reorganization of The Fiji Times.

133 “'Stuart Inder Joins Editorial Staff," PIM, 28, no. 2 (September 1957): 18.

Short sketch of Inder's professional background.

134 “They Love Us (Mostly) But Their Gripes Are Keen-Edged," PIM, 40, no. 3 (March 1969): 47, 49, 51.

Results of a reader survey.

135 “'Wilke Buys Into 'PIM' and 'The Fiji Times' Group," PIM, 41, no. 7 (July 1970): 20, 127-28.

Announces purchase by Wilke and Co., Ltd., Sydney, of 40 percent of ordinary shares of Pacific Publications Printing Ltd., Sydney; short histories of both companies and information on value of stock.

136 Inder, Stuart. "Like the South Seas, We've Widened Our Horizons," PIM, 41, no. 8 (August 1970): 83, 85 .

Information on the operation and management of Pacific Islands Monthly by its editor.

137 Robson, R. W. "PIM Was Born So Islanders Could Exchange The News," PIM, 41, no. 8 (August 1970): 67-68.

Background on the early years of the magazine by its founder and first editor.

138 Tudor, Judy. "We Only Just Survived the Pacific War," PIM, 41, no. 8 (August 1970): 69, 71, 73.

Magazine's second editor reminisces about difficulties of publication during World War II.

139 “'Up Front with the Publisher,” PIM, 46, no. 11 (November 1975): 3.

Reviews editorial changes in PIM; Stuart Inder, longtime editor became publisher; John Carter became editor. 


\section{Rongo}

140 “Paper Aims to Help Polynesians," Tonga Chronicle, January 31, 1974, 7:2.

Reviews Rongo, newspaper first published in Wanganui, New Zealand, in January 1974. Article reports 23,000 copies printed; newspaper articles written in Rarotongan, Maori, Samoan, Tongan languages (60\%) and in English (40\%); newspaper's aim: to help unite Polynesian and Pacific Island people.

\section{South Pacific Islands Business News}

141 “New Title for Business Publication," PICN, 5, no. 3 (September 1975): 2.

Two-year old business journal, Hosting and Purchasing, changed title to South Pacific Islands Business News; published in Suva, Fiji.

\section{PRESS/BROADCASTING ORGANIZATIONS Asia-Pacific Broadcasting Union (formerly Asian Broadcasting Union)}

142 Sherman, Charles E. "The Asian Broadcasting Union," Journal of Broadcasting, 13, no. 4 (Fall 1969): 397-414.

ABU history, organization, and activities.

\section{Pacific Islands News Association}

143 “Pacific Press Association Aid Sought," PICN, 4, no. 3 (May 1974): 1.

Details planning of Pacific Islands News Association meeting; individuals and organizations involved with establishment of meeting.

144 “Pacific Editors To Meet in Suva," Atoll Pioneer, June 13, 1974.

Meeting to be held in Suva to help support Pacific Islands Press Association.

145 “'Pacific Press Association Aid Sought," Tonga Chronicle, June 20, 1974, 3:1; 7:4-5.

Notes Pacific Islands News Association meeting to be held in Suva, Fiji, in late June, 1974.

146 Richstad, Jim. "Working Paper on Organization of Pacific Islands Press Foundation," Pacific Islands News Association Conference, Suva, Fiji. June 24-28, 1974. 4 pp.

Reviews developments since 1972 South Pacific Editors Conference, when the participants stressed the need for training, exchanges, newsletter and other professional concerns. Brief review of functions of the Foundation, with financing considerations and a mock budget listed for discussion.

147 Pacific Islands News Association. "Recommendations of Organising Committee."' Suva, Fiji. June 27, 1974. 8 pp.

Outlines guidelines for Pacific Islands News Association (PINA), listing professional standards and protection, training, information exchange, clearing house services, advisory services. Various administrative details explained. Appendixes include: A) Possible funding sources; B) Possible scholarship sources and training centers; C) Dummy budget.

148 Tekaai, Timai. “News People Form Association,"' Atoll Pioneer, July 11, 1974, p. 2.

Reviews Pacific Islands News Association meeting; organizational structure and aims. 
149 "PINA Gets Underway, Names Usher Director," PICN, 4, no. 4 (September 1974): 1.

Describes aims, membership of new journalism association.

150 "PINA's Organizing Guidelines; Training Focus," PICN, 4, no. 4 (September 1974): $2,3$.

Outline of association's original goals in training, information exchange, advisory services, membership.

151 "Chairman Outlines PINA Needs in Europe and North America" PICN, 5, no. 1 (February 1975): 2.

Leota Pita Alailima, chairman of PINA organizing committee, explains the organization's needs. Article lists highlights of 77-day world tour.

152 "PINA Gains Members, Expands Activities," PICN, 5, no. 1 (February 1975): $1,19$.

Pacific Islands News Association has temporary home in the Media Center of the University of the South Pacific, Suva. Article reviews developments in organization and information about chairman of organizing committee, Leota Pita Alailima.

153 Usher, L. G. "News Communication in the Pacific," Paper prepared for the Users of PEACESAT Conference at the East-West Center, Honolulu, April 30, $1975.11 \mathrm{pp}$.

Formation of Pacific Islands News Association is briefly reviewed in the context of other Pacific Island communication innovations. Development of newspapers in the Pacific region is summarized in order to stress the need for developing policy guidelines for effective news dissemination. Priorities of organization reviewed.

154 “PINA Committee Meets in Honolulu," PICN, 5, no. 2 (June 1975): 6.

Organizing members of PINA meet in Honolulu for the first time since the committee was formed in Suva in 1974; article reviews meeting.

155 “PINA News Circulated," PICN, 5, no. 2 (June 1975): 6.

PINA News, an experimental bulletin, is put out by L. G. Usher.

156 "Leota Pita Alailima Resigns as PINA Chairman; Cites New Responsibilities," PICN, 5, no. 3 (September 1975): 1.

Managing director of the weekly South Seas Star in Apia resigns as chairman of PINA organizing committee.

157 "PINA postpones October meeting on constitution," PICN, 5, no. 3 (September 1975): 7.

L. G. Usher announced PINA meeting was postponed; draft constitution for the organization was "well ahead,"

\section{8 “PINA," PICN, 6, no. 2 (June 1976): 12.}

Pacific Islands News Association developing a journalism training program in Suva; will concentrate on basic principles of journalism presented in short, concentrated intervals for class of about 25 trainees. 


\section{Press Congress of the World}

159 "Pacific Communications Come to the Fore," Editor \& Publisher, 20, no. 54 (December 17, 1921): 7.

Pan-Pacific press conference delegates reassemble in Washington to urge continuance of naval radio service and improved facilities.

160 Pan-Pacific Union. First Pan-Pacific Press Conference: A Regional Section of the Press Congress of the World-Program and Proceedings. Honolulu: Honolulu Star-Bulletin, $1921.95 \mathrm{pp}$.

161 "Press Congress Convention" in Thos. G. Thrum, comp., Hawaiian Almanac and Annual, 48th ed. Honolulu: Thos. G. Thrum, Publisher, 1921, pp. 139-51.

Addresses, aims, list of delegates to Press Congress of the World in Honolulu, 1921.

162 Williams, Walter, ed. The Press Congress of the World in Hawaii. Columbia, Mo.: E. W. Stephens Publishing Co., 1922. 605 pp.

Proceedings and papers from congress held in Honolulu in October and November 1921.

\section{PRINTING}

163 Grey, George, and William H. I. Bleek. The Library of His Excellency Sir George Grey, Philology, vol. II. London: Trubner, 1858-59.

Lists many early printed works from Pacific Islands presses.

164 Darlow, T. H., and H. F. Moule. Historical Catalogue of the Printed Editions of Holy Scripture in the Library of the British and Foreign Bible Society. London: The Bible House, 1903.

165 "Linotypes in the South Pacific Islands," PIM, 32, no. 6 (January 1962): 114.

Short article says there have been linotypes in Papua New Guinea and Fiji for 30 or 40 years.

166 Lingenfelter, Richard E. Presses of the Pacific Islands, 1817-1867: A History of Printing in the Pacific Islands. Los Angeles: Plantin Press, 1967. 129 pp.

Chronological listing of presses and printers in major island groups.

\section{RADIO BROADCASTING}

167 “Australia Hears Concert Over KDKA," NYT, October 8, 1926, 3:2.

Shortwave broadcast from Pittsburgh, Pennsylvania, station heard in Fiji, New Zealand, and Australia.

168 “Australian Waves Reach West Coast," NYT, January 30, 1927, VIII, 18:3.

Station 3LO, Melbourne, heard in Pacific Islands, New Zealand, and U.S. west coast.

169 "Radio in the Islands," PIM, 1, no. 11 (June 1931): 4.

On the increasing popularity of radio; includes a few figures on receiver sales.

170 "Broadcasts for Islands: New A.W.A. Service," PIM, 2, no. 2 (September 1931): 16 .

Reports beginning of worldwide shortwave service by Amalgamated Wireless (Australasia), Ltd.

171 "New Broadcast at Townsville with Pacific Radius," PIM, 2, no. 4 (November 1931): 10.

Notes opening of station 4TO, Townsville, Queensland, to serve the South Pacific. 
172 Schutrumpf, E. D. Broadcast Advertising in Asia, Africa, Australia, and Oceania. Bureau of Foreign and Domestic Commerce, U.S. Department of Commerce, Trade Information Bulletin no. 799. Washington: Government Printing Office, 1932.

173 "Growing Use of Radio Receivers in the Pacific Islands," PIM, 3, no. 3 (October 1932): 40-41.

174 "Radio in the Colonial Empire," Crown Colonist, 11, no. 110 (January 1933): 51.

175 Union Internationale de Radio-Diffusion. Broadcasting Abroad, with a supplemental memorandum on radio broadcasting in the Far East and Southern Pacific by the American Council, Institute of Pacific Relations, rev. ed. Chicago: University of Chicago Press, 1934.

176 "Islands Radio: Special Broadcast from Townsville," PIM, 4, no. 9 (April 1934): 38.

Reports official discussion of increased use of radio for news and entertainment.

177 "Townsville Radio Station: Special Broadcast for Islands," PIM, 4, no. 10 (May 1934): 12.

Official statement of plans for improved service.

178 “Outrageous Radio Fees Imposed on Pacific Listeners," PIM, 5, no. 8 (March 1935): 63.

Criticizes the levying of license fees on radio receivers.

179 "Broadcasting Developments," Crown Colonist, 6, no. 61 (December 1936): 564.

180 “Mad Morse Signals: Japanese Interference with Pacific Radio," PIM, 9, no. 11 (June 1939): 34-35.

Describes interference with reception of Australian radio stations in the Pacific, with particular reference to a Japanese transmitter.

181 “'Gives Radio Service to Men 'Down Under,' "' NYT, June 22, 1942, 17:5.

General Electric Co. station in Schenectedy, N.Y., plans two-hour daily shortwave program beamed to southwest Pacific.

182 Lader, Lawrence. "Island Programs: Notes on the Army-Operated Network in the Pacific Battle Zones," NYT, December 17, 1944, II, 9:3.

Programming and operations of American forces stations in the Solomon Islands, New Caledonia, New Hebrides, and New Zealand.

183 “NZ Installs Short-Wave Radio for Islands," PIM, 17, no. 1 (August 1946): 12.

New transmitter planned for Wellington to improve service to islands.

184 "Broadcasting to the Pacific: BBC Asks Residents for Reception Reports," PIM, 17, no. 3 (October 1946): 51.

Reprints remarks broadcast by head of BBC Overseas Engineering Department describing difficulties of improving service to the Pacific from Great Britain. 
185 “'Radio New Zealand Popular in Islands," PIM, 20, no. 8 (March 1950): 74. New Zealand government shortwave station said to have large audience after two years of operation.

186 “Gospel by Radio Planned for Islands Natives," PIM, 22, no. 4 (November 1951): 81 .

Reports plans of Christian Radio Missionary Fellowship to set up international missionary broadcasting station at Darwin and to distribute radio receivers.

187 “Island Radio Broadcasts,” PIM, 22, no. 4 (November 1951): 112.

Broadcast schedules of stations in New Zealand, French Polynesia, Western Samoa, and New Guinea.

188 "Australian Radio Transmissions to South Pacific Islands," PIM, 24, no. 3 (October 1953): 71.

Radio Australia adds two daily transmissions for Pacific Islands.

189 “'Radio NZ Daytime Service," PIM, 24, no. 4 (November 1953): 61.

Notes initiation of a daytime news broadcast with items of interest to islanders.

190 “'Radio NZ Gives Poor Service,” PIM, 27, no. 1 (August 1956): 20.

Programs intended for islands poorly received; low budgets and low power; improved news programs needed.

191 “'Broadcasting in the Pacific," $S P B, 6$, no. 4 (October 1956): 41-45, 56.

Describes broadcasting facilities in various Pacific Island areas.

192 “Clearing House Service for Pacific Broadcast Recordings," SPB, 7, no. 2 (April 1957): 41-42.

Describes an exchange program operated by South Pacific Commission.

193 Crozier, Mary. Broadcasting (Sound and Television). London: Oxford University Press, 1958. 236 pp.

History of British broadcasting with some review of broadcasting in British colonies in Pacific.

194 Codding, George A., Jr. Broadcasting Without Barriers. Paris: Unesco, 1959.

Examines development and activities of the world's broadcasting systems; scattered references to Pacific Island areas.

195 “'New Zealand 'Calls the Cooks,'” PIM, 30, no. 5 (December 1959): 43.

Notes a Radio New Zealand program conducted in the Maori language.

196 “Now They Can Learn Japanese By Radio," PIM, 30, no. 9 (April 1960): 126-27.

Notes Radio Japan language lessons for English-speaking listeners in the South Pacific.

197 "Increased Interest in Pacific Broadcasting," PIM, 31, no. 2 (September 1960): 49.

Broadcasting improvements planned in Tonga, Fiji, and Western Samoa.

198 "Problems of Film Censorship and Radio Broadcasting," PIM, 31, no. 7 (February 1961): 80.

Papua New Guinea film censorship and broadcasting developments reviewed.

199 “'Pop Tunes Are Preferred," PIM, 31, no. 9 (April 1961): 47.

Letter to editor disputes information in article carried in February 1961 issue. 
200 “'Radio Australia Voted Tops," PIM, 32, no. 8 (March 1962): 71.

Results of poll conducted by International Short-Wave Club.

201 “Radio Entertainment and Advertising," PIM, 32, no. 10 (May 1962): 25.

Letter to editor criticizing radio license fees and advertising; editor's comments.

202 Briggs, Asa. The Golden Age of Wireless. The History of Broadcasting in the United Kingdom, vol. 2. London: Oxford University Press, 1965. 688 pp.

Chapter 5 treats British Broadcasting Corporation activities for overseas areas.

203 Emery, Walter B. National and International Systems of Broadcasting: Their History, Operation and Control. East Lansing: Michigan State University Press, 1969. $752 \mathrm{pp}$.

A few references to Pacific Island areas.

204 Erakrik, Judah. "Radio or TV," PICN, 3, no. 1 (August 1972): 8.

On the benefits of radio communications.

205 South Pacific Commission Radio Bureau. "Broadcasting Exchange in the Pacific," $A B U$, no. 89 (October 1972): 23-24.

Describes plans for a Suva-based program to exchange broadcast material which may be useful to other Pacific countries.

206 "NZBC Aims to Improve Radio Service to the South Pacific," Tonga Chronicle, September 13, 1973, 12:1.

Reports a study team coming to South Pacific islands to find out how many radio listeners actually hear New Zealand Broadcasting Commission programs, what kinds of programming will raise interest of listeners. Article reports that in a sample week of radio programming studied, out of $1361 / 2$ hours of broadcasting there was only 135 minutes of programs directed to a specific Pacific island or to the islands in general.

207 Moses, Sir Charles. "Broadcasting in Asia and the Pacific-An Overview," Media Asia, 1, no. 2 (1974): 9-13.

Reviews the importance of radio broadcasting as basic communication link in developing countries; need for increased training in broadcasting skills.

208 Johnstone, Ian. "The South Pacific Commission's Acitivities in Broadcasting," $S P B, 24$, no. 3 (1974): 31-33.

Johnstone, SPC Educational Broadcasting Officer, describes the training and program exchange activities of the Commission. He concludes that television rather than radio will be the broadcasting medium Pacific countries will stress in developing.

209 Vusoniwailala, Lasarusa. "The Disc Jockey and National Policy: The Role of Radio in the South Pacific," The Pacific Way: Social Issues in National Development, ed. Siona Tupouniua, et al. Suva: South Pacific Social Sciences Association, 1975.

Reviews importance of radio to South Pacific island residents; some examples of the problems of radio stations in plural societies; the need for another station in Fiji, perhaps using English language; and aspects of the introduction of television into the islands.

210 Johnstone, Ian. "The Widening Sphere of the SPC's Work and Influence," $A B U$, no. 91 (January 1975): 7-10.

Reviews developmental activities in health, economic, and social fields; radio broadcasting emphasized. 
211 MacKay, Ian K. "How Radio Came to The Islands," PIM, 46, no. 10 (October 1975): 58-59.

A short history of the beginnings of radio broadcasting in various Pacific islands.

212 “'SPC Educational Broadcasts Officer," $A B U$, no. 118 (December 1975): 4.

Career profile of Himalea Douglas, South Pacific Commission broadcasting staff member.

213 “They've Cut New Zealand's Vocal Cords," PIM, 47, no. 6 (June 1976): 18.

New Zealand administration stops Radio New Zealand's overseas services due to budgetary problems.

214 "Radio NZ To Commence External Service," Cook Islands News, June 3, 1976, p. 1.

Radio New Zealand overseas services to resume with rebroadcasts of the National Program rather than special programs.

215 Barney, Ralph D. "Pacific Islands Broadcasting," Broadcasting in Asia and the Pacific, ed. John Lent. Philadelphia: Temple University Press (forthcoming).

An overview of broadcasting in various Pacific islands.

\section{SATELLITE COMMUNICATION}

216 “NASA Invites State to Use Satellite," $S$ - $B$, September 10, 1970, C-3:1.

Reviews status of proposal by University of Hawaii to use ATS-1 (Applications Technology Satellite) for multi-national educational experiment.

217 "State Seeks School Link Via ATS-1," SBA, November 1, 1970, A-5.

Reviews application by State of Hawaii to use ATS-1 satellite for educational purposes in a project proposed by Dr. John Bystrom, University of Hawaii professor of speech-communication.

218 “Plans Crystallize for Hawaii Satellite," PICN, 2, no. 1 (February 1971): 1-2. Information on the early planning of PEACESAT project.

\section{9 “UH Gets New Space Role,” S-B, August 9, 1971, A-3.}

Reviews permission for NASA ATS-1 satellite to be used by University of Hawaii for programs in education, health services, cultural programs and other subjects.

220 Nose, Katashi. "Using the ATS-1 Weather Satellite for Communications," QST, 55, no. 12 (December 1971): 48-52.

Reviews more technical information about communications by satellite.

221 "A Satellite Link with Hawaii," The Gisborne Herald (N.Z.), December 14, $1971,20$.

Reviews Wellington Polytechnic satellite communication system hook-up with University of Hawaii. (Article reviewed by the Dunedin Star, December 12, 1971.)

222 Bystrom, John W. The PEACESAT (Pan-Pacific Education and Communication Experiments by Satellite) Project: A Report for the International Communication Association. Honolulu: University of Hawaii, Department of SpeechCommunication, 1972.

Describes the PEACESAT Project and its emphasis on educational services in the Pacific Basin via NASA's ATS-1. Covers administration, studies of needs, instruction, services, evaluation, and benefits. 
223 " "The PEACESAT Project: Telecommunications and International Development in Health and Education," Eurospace Conference, New York, 1972. $14 \mathrm{pp}$.

Reviews history and goals of PEACESAT Project, stressing its importance in meeting social needs; importance of two-way exchanges and how the PEACESAT network has built on this model for many kinds of educational or social programs is discussed, as well as cost comparisons between satellite and other types of communications.

224 Cutting, Alan, and David Berkowitz. "PEACESAT-A Report on the Progress of an Experiment in International Educational Communication." University of the South Pacific. 1972. 22 pp.

Reports University of South Pacific satellite system; includes information on communication exchanges with many Pacific Islands.

225 Bystrom, John, Katashi Nose, and Abelina Costa. Second interim report to the National Aeronautics and Space Administration from The University of Hawaii February 4, 1972. Pan Pacific Education and Communication Experiments by Satellite. $18 \mathrm{pp}$.

Report reviews the purposes and administration of PEACESAT, network development, user applications, a technical report, and future project needs.

226 Helton, William. "Satellite Brings People of Pacific Closer," New Zealand Herald, March 16, 1972, A-10.

Reviews start of satellite communications in New Zealand with opening of Wellington Polytechnic terminal.

227 "Satellite Link Between Polytechnic \& Hawaii Working Well," Evening Post (Wellington, N.Z.), March 18, 1972.

Review of PEACESAT Project activities.

228 “Discussion Through Satellite," British Newsletter, May 16, 1972, p. 4.

Reviews satellite link between students at University of the South Pacific and the University of Hawaii.

229 “Satellite to Unite Pacific Islands," PICN, 3, no. 1 (July 1972): 1.

Interview with director of PEACESAT project on future of satellite communication in the Pacific Basin.

230 "Wider Education Satellite Links," Evening Post, (Wellington, N.Z.), August 8, 1972.

Reviews talk on PEACESAT system by John Bystrom.

231 “'Le Projet 'Peacesat' et ses Applications," La Dépêche de Tahiti, August 11, 1972, p. 6.

Reviews PEACESAT Project.

232 “'Lessons Swap by Satellite," PIM, 43, no. 9 (September 1972): 26.

Reviews economics and programs of PEACESAT system.

233 Creamer, Beverly. "PEACESAT Has Been 'A Learning Experience'," $S-B$, October 10, 1972, A-15.

Reviews PEACESAT programs. 
234 "Satellite Link Between Polytechnic and Hawaii Working Well," Evening Post (Wellington, N.Z.), October 18, 1972.

Wellington Polytechnic granted one-year approval to experiment with satellite communication educational projects.

235 Engler, Nicholas A., Jerry D. Strange, and Gerald F. Hein. Compendium of Applications Technology Satellite User Experiments, 1967-1973. Final Report. University of Dayton Research Institute, Dayton, Ohio. Various pagings.

Report summarizes user experiments from 1967-1973 using ATS satellite series. Experiments include voice, teletype and facsimile transmissions. Particular emphasis given to Alaska and Hawaii experiments. Technical information such as operating characteristics and structure of the various ATS satellites, and use of ATS satellites for ranging and position fixing of ships and aircraft, reviewed. Appendices include keyword-accession number listing and bibliography.

236 Polcyn, Kenneth A. An Educator's Guide to Communication Satellite Technology. Washington: Information Center on Instructional Technology, Academy for Educational Development, 1973. 99 pp.

Briefly describes PEACESAT project.

237 Richstad, Jim, and L. S. Harms, eds. World Communication: Population Communication, Communication Technology, Communication in the Future. Honolulu: East-West Center, 1973. 96 pp.

Volume contains three articles on PEACESAT project. John Bystrom, "The PEACESAT Project: The Approach," discusses basic assumptions of project. Katashi Nose, "The PEACESAT Project: Ground Terminal Hardware." Paul C. Yuen, "The PEACESAT Project: Application of Communications Satellite Technology," discusses the capabilities of the ATS-1 satellite.

238 "Satellite Network Expands in Pacific Basin," American Libraries, 4, no. 4 (April 1973): 192-93.

General background on PEACESAT project.

239 "Saipan Joins University's Pan-Pacific Radio Network," $A D V$, April 18, 1973, F-12.

Reviews Micronesian satellite communication station's start of operations.

240 “The 'Dom' in Pacific Link-up," The Dominion, (Wellington, N.Z.), May 17, 1973 , p. 2.

Reviews satellite Press Conference of the Pacific.

241 Hanley, Anthony. "The Wellington Polytechnic Satellite Communication Programme," New Zealand Engineering, June 1973.

Paper reviews Wellington Polytechnic satellite communication program history, EDSAT and PEACESAT programs, technical details such as clarity of facsimile copy of skull X-ray and electrocardiograph signal sent over PEACESAT satellite communications network, signal strengths. Results summarized.

242 "The Serendipity of Synchronous Satellites," Vectors Magazine, 15 (Summer/Fall 1973): 26-29.

Describes several demonstration projects using the ATS-1 satellite, including the PEACESAT project.

243 “Editor's Conference Followup," PICN, 4, no. 1 (August 1973): 5.

Satellite discussion on areas of interest to Pacific editors, e.g., training, formation of press association, journalism courses. 
244 “Late News Bulletin: Peacesat Victim of Budget Cuts," PICN, 4, no. 1 (August 1973): 1.

Short notice of withdrawal of financial support from PEACESAT project by Hawaii Legislature.

245 "'Press Conference of the Pacific Gets Going," PICN, 4, no. 1 (August 1973): 1 .

Describes use of satellite project for press conference among Pacific Islands.

246 Benson, Bruce. “UH Satellite to be Stilled,” SBA, August 12, 1973, A-1:3.

Reviews imminent shutdown of PEACESAT project due to conflict over question of whether satellite system competes with domestic, private satellite communications companies.

247 "Search to Save UH's Satellite System," $A D V$, August 16, 1973,

A-15:1.

Reviews economic problems in funding PEACESAT project.

248 “'PEACESAT Problems," $A D V$, August 16, 1973, A-20:1.

Editorial stresses importance of PEACESAT system and hope for funding to continue program.

249 Benson, Bruce. “Mink Asks Satellite Reprieve,” SBA, September 2, 1973, A-11:2.

Rep. Patsy Mink asks NASA to reverse decision to stop PEACESAT project on question of whether PEACESAT competes with the domestic business of private communications companies.

250 Griffin, John. "Meet the Press: Viewing Tourism," $A D V$, September 22, 1973, A-11.

Reviews Press Conference of the Pacific using satellite; conference dealt with tourism.

251 “Radio, TV News Training Discussed on PEACESAT," PICN, 4, no. 2 (December 1973): 5-6.

Reviews subject-matter of three PEACESAT teleconferences, held in October and December.

252 White, Margaret. "USP to Add 8 Satellite Terminals," PICN, 4, no. 2 (December 1973): 1.

Describes plans and reviews University of South Pacific satellite extension services.

253 Hanley, Anthony. "Experimental Satellite Networks in the Pacific Hemisphere." New Zealand Electronics Conference, Auckland, New Zealand, 1974. $20 \mathrm{pp}$.

Reviews experiments in international conference telecommunications for social benefit, such as: Alaskan Medical Project; Alaskan Educational Project; PEACESAT Project; University of the South Pacific Project; the Micronesian Network Project; University of Hawaii ALOHA Project, PACNET, PEACENET; other satellite-linked network experiments, ATS-6 and CTS Projects. Experiences in the problems and potential uses of such networks are reviewed and current activity and future plans discussed.

254 Misko, Carol. “Exploration in Intercultural Exchange by Satellite." International Communication Association Conference, New Orleans, Louisiana, 1974. 5 pp.

Reviews present communication environment for less industrially advanced nations and how the PEACESAT Project was designed to help remedy disadvantages when communicating with the other nations in the satellite communication system. Examples of intercultural uses are presented, with suggestions for facilitating exchanges. 
255 Satellite: The PEACESAT Bulletin. Wellington, N.Z. 1974-. Weekly.

Bulletin of information and program schedules of Wellington Polytechnic satellite terminal.

256 “Peace-Sat is Instant Link for Islands," Fiji Times, January 24, 1974.

Reviews benefits and purposes of PEACESAT project and recent exchanges.

257 Friedman, Bruno. "Satellite Hub of Pacific Classroom," $A B U$, no. 102 (March 1974): 33-34.

Article condensed from Unesco Features; reviews PEACESAT project of linking nine educational centers in Pacific in early 1970s.

258 Bystrom, John. The PEACESAT Project (Pan-Pacific Education and Communication Experiments by Satellite), University of Hawaii. Testimony of John Bystrom, Project Director, Before the (Hawaii) House Committee on Higher Education, March 7, 1974. 7 pp.

Testimony in support of financial appropriation.

259 Seumahu, E. S. "Satellite Communication Project, October 1971-June 1974," Departmental Report R18/74, Papua New Guinea University of Technology, July 1974. 23 pp.

Report reviews project to assemble satellite station, join the PEACESAT project and begin regular exchanges with other institutions in the Pacific area on technical, educational, cultural, medical, and public relations matter, plus individual exchanges. Paper presents technical performance of the ground station, costs and funding, recommendations, bibliography.

260 “'Satellite Broadcast of Lectures," $A D V$, July 17, 1974, A-12.

Announces that Earth 2020 lecture series will be broadcast to many Pacific Islands via satellite in late July 1974; reviews topics of the lectures.

261 "Satellite," New Works: The Journal of the Combined Social Club of the Ministry of Works and Developing, 5, no. 1 (Autumn 1974): 35-37.

Reviews PEACESAT project.

262 Bystrom, John. "Satellite Communication Applied to the Needs of Developing Areas: The Peacesat Experiment." A paper presented at the Second International Conference on Computer Communication, Stockholm, August 12-14, 1974. $7 \mathrm{pp}$.

Reviews PEACESAT structure, activities, facilities, and efforts to apply satellite communication to the social requirements of remote areas.

263 "Peacesat Problems," $A D V$, August 16, 1974, A-20:1.

Editorial reviews financial problems and political considerations that may halt PEACESAT Project.

264 “News Exchange Experiment Utilizes ATS-1 Satellite," PICN, 4, no. 4 (September 1974): 7.

Report on regional news exchange program after three-month test period.

265 “'Satellite Terminal Set Up in Tarawa," Atoll Pioneer, September 10, 1974, pp. $1,2$.

Reviews establishment of Tarawa's satellite terminal. 
266 Bystrom, John. "Pan Pacific Education and Communication Experiments by Satellite 1971-74: The Application of International Interactive Service Support Communication." Paper prepared for a meeting of the Royal Society of London on the introduction of satellites into education systems, September 19-20, 1974. $34 \mathrm{pp}$. (Published in Proceedings of the Royal Society of London, 345 (1975): 493-510.)

Surveys the development and operations of the project with emphasis on use of satellites in support of educational and social services; contains many examples of satellite communication applications and suggestions for further experimentation.

267 "Increasing Intercultural Communication: The PEACESAT Experiment, A Study in the Social Benefits of International Interactive Exchange by Communication Satellite, International and Intercultural Communication Annual, Speech Communication Association, 1 (December 1974): 39-43.

Paper reviews history, specifications, utilization, and impact of the PEACESAT Project.

268 Callison, George. "PEACESAT: Communication by Satellite for Micronesia," Micronesian Reporter, 22, no. 4 (1974): 38-42.

Reviews history of PEACESAT Project's activities in Micronesia.

269 Hanley, Anthony. "Small Earth Terminals for Satellite Communication Systems." New Zealand Electronics Conference, Wellington, New Zealand, 1975.

270 Misko, Carol. "The PEACESAT Project: International Cooperation and Exchange by Satellite." A Report on University Applications of Satellite/Cable Technology, University of Wisconsin. 1975. pp. 68-72.

Reviews goals of the PEACESAT Project when it started at University of Hawaii in 1969; phases project has been through; examples of projects.

271 PEACESAT News File 1970-1975. Honolulu: PEACESAT, University of Hawaii, $1975.78 \mathrm{pp}$.

A scrapbook of articles from a variety of newspapers illustrating wide use of PEACESAT programs in Pacific nations.

272 "EWC Conference to Discuss Uses of Satellite Communication," PICN, 5, no. 1 (February 1975): 20.

Users of the PEACESAT communication system in the Pacific Islands will be subject of a week-long conference at East-West Center in April 1975.

273 “'Satellite News Exchange Report," PICN, 5, no. 1 (February 1975): 3-5.

Review of early history of PEACESAT news exchange by Ian Johnstone, Education Broadcast Officer of the South Pacific Commission, who conducted a three-month experiment in 1974 to test system.

Report includes information on the system of exchange, reception, list of participants, and statements of the use of news.

274 Bystrom, John W. The PEACESAT Project: Pan Pacific Education and Communication by Satellite. Testimony presented to the Hawaii State House Committee on Higher Education. University of Hawaii, March 1975.8 pp. Appendices.

Documents the history and postulates the future of the PEACESAT experiment. Testimony includes purpose, facilities, activities, benefits, budget, selected viewpoints of users, and future possible applications. Chronological annotation of the experiment, conducted during 1970-75, and bibliography. 
275 "New Zealand Collaborates in International Communication Experiment," Management (New Zealand), 22, no. 1 (April 1975): 22.

Reviews PEACESAT system and its programs.

276 Blundell, Margaret. "PEACESAT and the Smaller Terminals: To Big Brother With Love." Paper prepared for the Users of PEACESAT, April 28-May 2, 1975. East-West Communication Institute, East-West Center, Honolulu, Hawaii. 3 pp.

Reviews problems in PEACESAT programming, especially concerning small-island users: e.g., shortness of timing for an exchange, speakers taking too much time. Author suggests late-evening conference on topics of great interest to many listeners.

277 Hanley, Anthony. "Satellite Communications Networks Experiments: A Review." Paper presented to the Users of PEACESAT Conference, April 28-May 2, 1975. East-West Communication Institute, East-West Center, Honolulu, Hawaii. $20 \mathrm{pp}$.

Review of the use of communication satellites for linking a large number of small earth terminals, each having the capacity to transmit and receive. Presents table of major satellites launched; when launched; if operation was successful, etc., for the period 1962-74. Discusses ATS-1 satellite and some of the projects using it.

278 Richstad, Jim. "Press Conference of the Pacific." Paper prepared for the Users of PEACESAT Conference, April 28-May 2, 1975. East-West Communication Institute, East-West Center, Honolulu, Hawaii. 5 pp.

Reviews concept of a press conference format over PEACESAT that developed in early 1973 at the East-West Communication Institute. Purpose was better exchange of news through a journalistic format.

279 Rosen, Leon. Untitled paper prepared for Users of PEACESAT Conference, April 28-May 2, 1975. East-West Communication Institute, East-West Center, Honolulu, Hawaii. 7 pp.

Paper reviews usefulness of satellite communications between isolated Pacific Islands for medical consultation.

280 Evinger, Jane. "Satellite, Computer Link Eyed," $A D V$, May 4, 1975, D-1.

Linking computers and satellites may be a way to help developing nations overcome shortages of trained workers, an Australian expert suggested at an international conference held at East-West Center. Article reviews some of the discussions on the PEACESAT projects from that conference.

281 “Hawaii \& Peacesat," SBA, May 4, 1975, H-2:1.

Editorial reviews recent conferences about PEACESAT system's value to illustrate near loss of program two years earlier due to short-sightedness.

282 “UH Course Will Go Far by Satellite," $A D V$, May 31, 1975, A-8:2.

Reviews start of communication course being offered through satellite to students in Pacific Islands.

283 "'Sixty Meet to Examine PEACESAT Communication in Pacific," PICN, 5, no. 2 (June 1975): $1,7$.

Reviews Users of PEACESAT Conference, held in conjunction with the Communication in the Pacific Conference, to bring together participants in the 11-territory satellite communication system. 
284 Usher, Len. "Satellite Over the Pacific: An Experiment in Public Service Communication." Pacific Islands News Association in Association with the Extension Services of the University of the South Pacific, June 1975. 7 pp.; map.

Reviews status of satellite projects in Pacific, mainly the PEACESAT project; organization and licensing of existing terminals reviewed; Pacific Regional News Exchange briefly explained. A resolution adopted at a Conference of the Users of PEACESAT, East-West Communication Institute, Honolulu, May 1, 1975, is given. Map of terminals.

285 “PEACESAT Expands," PICN, 5, no. 3 (September 1975): 2.

New terminal for PEACESAT communications system began operation in Port Vila, New Hebrides, July 14, 1975; South Pacific Commission also recently joined five other members in the PEACESAT consortium.

286 “Peacesat,” PICN, 5, no. 4 (December 1975): 10.

Review of Peacesat project reports, listing of terminals.

287 "PEACESAT Aids S. Pacific Arts Festival." PICN, 5, no. 4 (December 1975): 18.

PEACESAT served as link in planning South Pacific Festival of Arts.

288 “PEACESAT S.P. Games News," PICN, 5, no. 4 (December 1975): 12.

PEACESAT terminal on Saipan was only source of information for some participating countries in the South Pacific Games, held in August, 1975.

289 Negus, Christine. "Satellite Link Brings People of Pacific Closer," The Dominion (Wellington, N.Z.), January 14, 1976, 4:2.

Reviews early PEACESAT project history; start of New Zealand's participation.

290 Bystrom, John. "Satellite Communication for Social Development," Educational Broadcasting International, 9, no. 1 (March 1976): 35-39.

Article reviews PEACESAT project's emphasis on communication for social services in developing countries.

291 “PEACESAT Links 'Electric Pacific'," PICN, 6, no. 1 (March 1976): 2.

PEACESAT will provide program on importance of the electric age to ten Pacific Island nations on April 4, 1976. Program produced by Martin Hadlow will also be carried nation-wide on Radio New Zealand's Concert Program Network.

292 "Internal Communication Stressed on 'Electric Pacific' Program," PICN, 6, no. 2 (June 1976): 12.

Article reviews program held on April 4, for pan-Pacific conferencing including many islands as well as New Zealand stations.

293 Bystrom, John. "Peacesat Experiment General Description 1971-1976," Educational Broadcasting International, 9, no. 3 (September 1976): 103-107.

Reviews PEACESAT Project history and projects, with special emphasis on health and medical education exchanges.

294 “'Star-Bulletin Calls Peacesat 'Awesome,' Lauds Bystrom," PICN, 6, no. 4 (December 1976): 3.

Reprint of Honolulu Star-Bulletin editorial of December 6, 1976. 


\section{TELEVISION}

295 “'Radio or TV,” PICN, 3, no. 1 (August 1972): 8.

On the benefits of electronic communication.

296 Johnstone, Ian A. "From Closed to Open Television-A Long Term Project for the South Pacific." Presented at the Fifth Regional Education Seminar of the South Pacific Commission, Port Moresby, Papua New Guinea, February 12-16, 1973. 11 pp. Appendix. SPC/5RES/WP.2. February 7, 1973.
A need is seen for "cheap, simple, vernacular, rural-directed communications systems" in South Pacific countries. A proposal for such a program, using a "closed" television system rather than "open" transmission of programs from central stations to home receivers, is made, and cost and benefit figures are reviewed. Appendix lists basic equipment needed for such a system. Paper reviewed in PICN, 4, no. 2 (December 1973): 2.

297 Proceedings of The First Asian Pacific Television Conference, June 23-29, 1975, Taipei, Republic of China. Seoul: Cultural and Social Center for the Asian and Pacific Region. 117 pp.

Conference held to discuss clearing house for TV programs among countries in the Pacific Region; includes report from Guam cable TV organization on exchange program with Taiwan.

298 “Television for the Loyalties," PIM, 46, no. 11 (November 1975): 80.

Article reviews schedule for introduction of TV into various South Pacific islands. 


\section{American Samoa}

\section{NEWSPAPERS, PERIODICALS}

299 THE ADVERTISER. Pago Pago. June 1976-. Weekly in English. Published by Transpac Corporation. Superseded Samoan Sun (October 1974-March 26, 1976).

300 AMERIKA SAMOA. Pago Pago. June 1973-July 1974. Monthly in English. Published by Office of Samoan Information, Government of American Samoa. An illustrated magazine. Superseded Samoa Scene (December 1972-May 1973), generally semimonthly.

301 FA'ASAMOA PEA. Pago Pago. May 1974-. Quarterly in Samoan and English. Published by Community College of American Samoa.

302 O LE FA'ATONU O LE KOLONE O UNAITE SETETE, TUTUILA MA MANUA. Pago Pago. 1903-55. Official gazette in Samoan and English. Files in the Office of the Governor, American Samoa, and in the Library of Congress. Microfilm at University of Hawaii.

303 NEWS BULLETIN. Pago Pago. July 12, 1965-. Published five days weekly by Office of Samoan Information, Government of American Samoa.

304 NEWS AND VIEWS BULLETIN. Pago Pago. April 8, 1963-? Irregularly published by American Samoan Chamber of Commerce. Title varies: Public Opinion Bulletin.

305 PAGO BEACH PRESS. Pago Pago. September 1, 1972-. Monthly in English.

306 PUBLIC OPINION BULLETIN. See News and Views Bulletin.

307 SAMOA ISLANDS MONTHLY JOURNAL. Pago Pago. January 1974-? Monthly. 
308 SAMOA NEWS. Pago Pago. April 1963-66. Published in Apia, Western Samoa (April 1963-April 1964). Weekly in Samoan and English. Titled in Samoan: Tala Samoa.

309 SAMOA NEWS. n.s. Pago Pago. August 6, 1969-. Semiweekly in Samoan and English; frequency varies. (Different newspaper from original Samoa News [1963-66].)

\section{SAMOA SCENE. See Amerika Samoa.}

311 SAMOA TIMES. Apia, Western Samoa. June 23, 1964-. Weekly in Samoan and English. For a time had editorial offices in both American and Western Samoa. Absorbed Western Samoa's Samoa Bulletin with May 25, 1967 issue and issued in Western Samoa from then on. For a time from June 30, 1970 Western Samoa's edition of Samoa Times called Apia Edition.

312 SAMOAN SUN. Pago Pago. October 1974-March 26, 1976. Weekly in English. Superseded by The Honolulu Advertiser.

313 TALA SAMOAN. See Samoa News.

314 UNDERGROUND MONTHLY. Pago Pago. February 1975-April 1976. Monthly in English. Superseded Underground Press (May 3 to November 5, 1974), published monthly; frequency varied.

315 UNDERGROUND PRESS. See Underground Monthly.

\section{GOVERNMENT AND INTERNATIONAL AGENCY REPORTS}

316 American Samoa. Department of Education. Report of the Superintendent of Education to the Board of Education. Pago Pago. Annual. Education. Pago Pago. Annual.

318 American Samoa. Governor. Annual Report of the Governor of American Samoa to the Secretary of the Interior. Washington: Government Printing Office, $1951 / 52-$. Title varies.

319 United States. Department of State. American Samoa. Information on American Samoa Transmitted by the United States to the Secretary-General of the United Nations. Washington: Government Printing Office, 1947-. Title varies; prepared until $1950-51$ by the Navy Department.

320 United States. Senate. Committee on Interior and Insular Affairs. Information on the Government, Economy, Public Health, and Education of American (Eastern) Samoa. 86th Cong., 2d sess. Washington: Government Printing Office, $1960.62 \mathrm{pp}$.

A staff study; some references to government publications and broadcasting. 


\section{COMMUNICATION RESEARCH}

321 "Survey of Government Control of Media," PICN, 2, no. 2 (August 1971): $1-4$.

Summarizes findings of a survey of mass media and leadership attitudes in American Samoa and three other Pacific areas.

322 Barney, Ralph D. "Mass Media Roles in Development: A Descriptive Study from Four Developing Areas," Gazette, 19, no. 4 (1973): 222-38.

A study of the developmental news content of six newspapers, including the government News Bulletin of American Samoa; content analysis found little evidence of systematic inclusion of developmentoriented material in any of the six.

\section{EDUCATION AND TRAINING OF COMMUNICATORS}

\section{3 "Samoan Develops A Photo Finish," $A D V$, June 24, 1970, D-4:1.}

Fa'alepo Fa'alopo, Jr., assistant information officer of Office of Samoan Information, finished photojournalism course at East-West Center.

\section{EDUCATIONAL MEDIA}

\section{Radio}

324 Radio in American Samoa, PIM, 24, no. 4 (November 1953): 19.

Short item without caption reports that the Education Department assumed control of low-powered station WVUV, Pago Pago, for educational purposes.

\section{Television}

\section{Documents, Studies, Reports}

325 American Samoa. Department of Education. $A$ 'oa'oga fa'atelevise i Amerika Samoa; Educational Television in American Samoa. Pago Pago, 1965. 10 pp.

326 Berry, Paul C. Education by Television in American Samoa. Prepared for the U.S. Agency for International Development, Office of Technical Cooperation and Research, Division of Research and Analysis. Harmon-on-Hudson, N.Y.: Hudson Institute, $1965.96 \mathrm{pp}$.

327 Schramm, Wilbur. "Educational Television in American Samoa," in New Educational Media in Action: Case Studies for Planners, vol. 1. Paris: Unesco, International Institute for Educational Planning, 1967. pp. 11-57.

Covers the background, organizational framework, economics of the American Samoa educational television system and the lessons learned in the project; appendix includes a composite week schedule, supplementary instructional material, directions for teachers, and a list of principal equipment. Institute for Educational Planning, 1967. $175 \mathrm{pp}$.

Report on use, problems, effectiveness, and costs of instructional television, radio, and films; contains much material on educational television in American Samoa.

329 Griffin, John. “Coming of Age Via ETV.” New York: The Alicia Patterson Fund. $1968.9 \mathrm{pp}$.

One in a series of articles on Pacific Island life by a Honolulu Advertiser editor. While generally favorable on ETV in American Samoa, Griffin cites some dissenting views. 
330 Nelson, Lyle. Report of the Educational Television Task Force. Honolulu: University of Hawaii-American Samoa Contract, 1970. 88 pp.

A study of community-Department of Education interaction regarding educational television, the manner and extent to which television attained educational goals, and the adequacy of television facilities.

331 American Samoa. Department of Education. "Philosophy of the Department of Education."' Pago Pago, 1971. 59 pp.

Includes some policy statements on use of educational television.

332 Hawaii. University. Office of Foreign Contracts. University of Hawaii-American Samoa Contract; Reports on Educational Television. Honolulu, 1970-1972.

One volume combining four reports: (1) Report of the TV Manpower Survey Task Force, 1970; (2) Engineering Recommendations: American Samoa Educational Television System, 1970; (3) Report of the Redesign of Patterns of Use of Instructional Television in American Samoa Task Force, 1972; (4) Report of the Television Production Workshop, 1972.

333 DeMello, Milton. “The Role of ITV.' Pago Pago: American Samoa Department of Education, 1972.13 pp.

Memo from director of education outlining plans for implementation of recommendations of a committee on the role of instructional television.

334 Schramm, Wilbur. Big Media, Little Media: A Report to the Agency for International Development. Beverly Hills, California: Sage Publications, Inc., 1977. rev. ed.

A study of the uses of various instructional media in education; includes discussion of educational television in American Samoa. “ITV In American Samoa-After Nine Years."' Stanford: Institute for Communication Research, Stanford University. 1973. 55 pp.

Presents data from high school and elementary school experiences in language arts, math, and English-language proficiency tests, etc., on changes since the ITV project began. One general conclusion was that the longer the exposure to television, the better the student's English-language performance; however, at the same time, the attitude toward extensive TV-usage became more negative in both high school students and teachers. Costs of program reviewed.

\section{Journal Articles}

336 Wiegand, John A. "Teaching English on TV in Samoa," English Journal, 54, no. 2 (February 1965): 118-20.

Instructional methodology discussed by the educational television director, KVZK, American Samoa.

337 Rankin, R. F. "Educational TV Pulls American Samoa Enthusiastically into 20th Century," National Education (Wellington, N.Z.), 47 (May 1965): 158-61.

338 Zilen, Elizabeth, and William H. Thomas. "Teaching Language Arts in Samoa," Elementary English, 43 (November 1966): 730-31.

Analysis of the language arts program for grades one through eight developed for the first year (1964-65) of the American Samoa educational television project.

339 Fiedler, Martha L. "ETV Goes Way Out and Brings the World to Samoa," American Education, 3, no. 3 (March 1967): 14-17.

Background on the introduction of educational television. 
340 Stolz, Jack H. "Educational TV in a Pacific Paradise," CTA Journal, 63, no. 4 (October 1967): 18-22.

341 American Samoa. Department of Education. "ETV in American Samoa: A Co-operative System of Instruction, Making Use of Television," Educational Television International, 2, no. 1 (March 1968): $2 \mathrm{ff}$.

342 Bishop, Robert, and Carolyn Bishop. "Education Fa'a Samoa," Montana Education, 45 (November 1968): 11-12.

Reviews use of television in elementary school program. Team approach, using television teacher, research teacher and director, is outlined.

\section{3 “NAEB Declines ETV Option," Broadcasting, 76, no. 9 (March 3, 1969): 69.}

National Association of Educational Broadcasters declines to renew eight-year-old contract to advise American Samoa government; says governor consistently thwarted officials of association and local school system.

344 Skornia, H. J. "Some Lessons from Samoa," Audiovisual Instruction, 14 (March 1969): 55-58.

Generally favorable review of use of educational television by a former president of the National Association of Educational Broadcasters. Although he indicates some reservations, the writer says, "Virtually everything has proved to be teachable at virtually each age and grade level with the proper use of TV."

345 Hall, George. "Samoa: The Non-Conformist," Educational Screen \& AV Guide, 48, no. 5 (May 1969): 18, 23.

Examines the methodology and technology of teaching by television in American Samoa.

346 Masland, Lynne, and Grant Masland. "Some Cross-cultural Implications of Educational Television: The Samoan ETV Project," in Educational Television, ed. Robert F. Arnove. Stanford: Stanford University School of Education, 1973. pp. 383-416.

Reviews the ten-year history of educational television program to upgrade Samoan children's ability to speak English and other school skills. Problems of cultural bias in materials and rapid cultural changes are discussed. Article reviewed in Educational Broadcasting, 8, no. 2 (March-April 1975) and no. 3 (May-June 1975).

347 Cooney, Stuart. "American Samoa: In Our Own Image," Audiovisual Instruction, 18, no. 8 (October 1973): 26-7.

Examines the move to end dependence on educational TV in American Samoa. While supplying some data, he builds his essay on a number of questions, including: "television is said to have failed . . . is it we who have failed?"'

348 Hall, Roy J. D., Jr. "Paternalism, E.T.V. and Illiteracy," Samoa Islands Monthly Journal, 1, no. 2-3 (February-March 1974): 28-29.

Criticism of educational system, especially its use of television; asserts ETV "is an outrageously expensive and highly overrated mode of educating Samoans . . . a failure."

349 Van Til, William. "Looking From Abroad: American Samoa," Phi Delta Kappan, 55, no. 9 (May 1974): 633-34.

Author gives views about problems of ETV programming in American Samoan elementary schools after short visit. 


\section{Newspaper and Magazine Articles}

350 "American Samoa Has Hopes of TV Stations," PIM, 32, no. 7 (February 1962): 37.

Comments by the U.S. Secretary of the Interior about improvements in American Samoa school system; says television is the best means of educating the people.

351 "Education by TV to be Tried Out in Samoa," Hawaii Times, July 5, 1963, 6:1.

Gov. H. Rex Lee in San Francisco to recruit teachers for ETV system.

352 Kurrus, Ted. "Educational TV Will Help Solve Samoa's Problems, Governor Says," $S-B$, September 14, 1963, 2:3.

Gov. H. Rex Lee describes ETV system and other plans for American Samoa.

353 Altonn, Helen. "Samoans Will Be Taught by Television," S-B, May 11, 1964, 2:1.

Interview with Gov. H. Rex Lee; describes progress in construction of educational television system.

354 Chaplin, George. "Samoa's Bold Plan: TV Teaching," $A D V$, May 12, 1964, A-6:1

Background on reasons for introduction of educational television; facilities; budget. "Samoa to Develop TV Textbooks to 'Bring' World to South Seas," $A D V$, May 13, 1964, A-10:1.

Development of curriculum for educational television.

\section{6 "Pacific Areas Eye Samoa ETV," SBA, January 31, 1965, A-7:1.}

Gov. H. Rex Lee discusses ETV and other aspects of his administration.

357 Carib, Ralph. "Educational Television in American Samoa," SPB, 15, no. 2 (April 1965): 18-21.

How educational television was set up, including difficulties in establishing the system and information on the new school system.

\section{8 “'Doubts Over 'Total TV' Education,” PIM, 36, no. 6 (June 1965): 27.}

Discusses controversy over whether children should be taught entirely by television or whether television should be used as a teaching aid.

359 Kaser, Tom. "Samoan ETV Is Bold Corrective Move," $S$ - $B$, June 17, 1965, E-4:1.

Extensive review of beginning of educational television project.

360 "Classroom TV Comes to Samoa," Saturday Review, 48, no. 25 (June 19, 1965): 58-59, 72-73.

Background on the introduction, construction, and program content of educational television.

361 "ETV Doing Big Job in Samoa," ADV, April 14, 1966, A-38:2.

Gov. H. Rex Lee says in N.Y. speech that educational television is just beginning to realize its potential.

362 "Educators Laud Samoa's ETV Success," $A D V$, May 31, 1967, B-5:1.

Members of a group of American educators returning from a visit to American Samoa praise its educational television. 
363 "Educational TV Comes to Massacre Bay," PIM, 38, no. 10 (October 1967): 69.

Dedication of a new school where children will be taught by television in village of Asu.

364 “American Samoa: In Many Ways You've Got to Be Impressed," PIM, 39, no. 11 (November 1968): 60-67.

Article includes educational television system.

365 "Coming of (TV) Age in Samoa," Life, 65, no. 15 (November 15, 1968): $127-28$.

Photo essay; little text.

366 Kaser, Tom. "Samoa's No. 1 in TV Teaching," $A D V$, November 28, 1968, C-3:1.

Discusses American Samoa educational system with emphasis on use of television; concludes that evidence indicates the system is effective.

367 "Educational Television Rift in American Samoa," S-B, February 21, 1969, A-1:3.

Dispute with governor over ETV prompts National Association of Educational Broadcasters to terminate support contract with Government of American Samoa.

368 “Aspinall Issue Fraught With Dynamite," $S-B$, March 9, 1969, A-3:1.

A Washington Post article that includes details of the governor's dispute with the National Association of Educational Broadcasters, the group that operates the Samoan ETV system.

369 "Education in Samoa," $A D V$, March 18, 1969, B-3:3.

Letter from president of National Association of Educational Broadcasters explains termination of association contract with American Samoa.

370 "Behind the Shake-Up in American Samoa Television Education," PIM, 40, no. 5 (May 1969): 25.

Governor of American Samoa dissatisfied with management of ETV station run by National Association of Educational Broadcasters and turning operation over to the University of Southern California.

371 Lee, Rex. "ETV Can Aid Developing Nation," $A D V$, May 22, 1969, B-3:1.

Excerpts from speech by $\mathrm{H}$. Rex Lee, member Federal Communications Commission and former governor of American Samoa; examines overall question of using educational television with references to American Samoa experience.

372 Chase, Martyn. "UH to Study Samoa's Troubled ETV," $S-B$, December 10, 1969, B-10:1.

Approval of study to determine where television should fit into overall educational picture in view of disillusionment with heavy reliance on television.

373 Hewlett, Frank. "Television Teaching Called a Failure in Samoa," $S-B$, March 4, 1970, C-2:1.

Gov. John M. Haydon tells a Congressional committee in Washington that teaching by television is an "absolute failure"; reviews changes he wants in the ETV program.

374 "Education Lag in American Samoa Blamed on ETV," S-B, March 11, 1970, B-12:1.

Interview with Gov. John M. Haydon. 
375 “Instructional TV Termed Helpful in Samoa Schools,"' S-B, March 28, 1970, A-3:1.

Lark Daniel, director of Hawaii ETV system, reviews methods needed to upgrade Samoan ETV program.

376 “American Samoa's ETV Going Color," $A D V$, November 10, 1972, B-6:5.

Reviews reasons for changing to color television.

377 Lamb, David. “Television Teaching Fails to Pass Test in Pago Pago," Los Angeles Times, October 16, 1974, A-4:1.

Educational television now being de-emphasized in elementary school program. While a Samoan firstgrade student viewed TV $44 \%$ of his school time four years ago, he now watches TV $17 \%$ of his school day. TV now seen as a supplement to classroom teacher. (Reprinted in American Samoa News Bulletin, November 6, 1974; reviewed in PICN, June 1975.)

378 Senda, Warren. "Ex-officials Defend School TV System," $A D V$, January 14, 1975, A-5:1.

Milton De Mello, director of education in American Samoa from 1970-73, said that educational TV originally was used due to lack of qualified teachers but as more qualified teachers became available, television began to be used as a supplement. Stewart Cheifet, manager of the American Samoan television system from 1971-1973, stressed economic aspects. (Article reviewed in PICN, June 1975.)

379 Va'a, Felese. "Budgeting for Sunshine in Samoa," PIM, 46, no. 8 (August 1975): 76.

Proposed 1976 budget for American Samoa holds some significant changes for television if the Fono approves it. (Article reviewed in PICN, September 1975.)

380 Takeuchi, Floyd. "Jon A. Anderson Named New Television Chief for American Samoa," PICN, 5, no. 4 (December 1975): 1, 4.

New director of television operations for the government of American Samoa named.

\section{FREEDOM OF PRESS/BROADCASTING}

381 “They Want to Ban A. Samoa's News Bulletin," PIM, 39, no. 11 (November 1968): 39.

American Samoa legislature criticizes Office of Samoan Information for censoring news in its News Bulletin; local papers claim publication is unfair competition.

382 “'Samoa Expels Pollution Critic," $A D V$, July 20, 1971, A-1:1.

J. P. King, editor of Samoa News ordered to leave American Samoa; order being appealed.

383 “"Media Involvement in Governor Haydon-Jake King Dispute," PICN, 2, no. 2 (August 1971): 20-21.

Report on controversy over attempted expulsion of J. P. King from American Samoa; examines relations between governor and news media.

384 “'Defiant Newspaperman Irks Samoa's Governor," $S B A$, August 8, 1971, A-12:1.

Background article on efforts of J. P. King, publisher of Samoa News, to avoid deportation.

385 “'Jurist Another Target in Controversy," $S B A$, August 8, 1971, A-13:1.

Links transfer of Judge J. W. Goss with Goss's decision staying deportation order against J. P. King. 
386 Kaser, Tom. "Furor Spotlights Samoa Faults," SBA, August 8, 1971, A-13:1. Attempted deportation of J. P. King cited to illustrate influence of executive on judicial branch, inconsist ' $\eta$ enforcement of immigration regulations, and government monopoly of news dissemination.

387 "Democracy in American Samoa," NYT, August 14, 1971, 24:1.

Editorial says ordered deportation of J. P. King and transfer of Judge J. W. Goss compromises American principles of judicial independence and free press.

388 Blair, William M. "A Judge in Samoa I oses Bid to Stay," NYT, August 28, $1971,29: 4$.

Assistant secretary of the interior affirms transfer from American Samoa of Judge J. W. Goss; denies link between transfer and deportation order against newspaper publisher J. P. King; denies press freedom suppressed.

389 "Samoa Deport Order Reversed," $A D V$, August 28, 1971, A-16:1.

Judge reverses deportation order against J. P. King; says Immigration Board did not prove its case.

390 "Haydon Faces New Charges," S-B, September 18, 1973, A-16:1.

Assistant Attorney General Jim Kingzett charges Gov. John M. Haydon with violations of freedom of the press, accuses Haydon of trying to prevent a television reporter from interviewing a witness during proceedings against Haydon under the Hatch Act.

391 "Aide Fired After Filing Two Haydon Charges," $A D V$, September 21, 1973, D-1:3.

Assistant attorney general fired after charging Governor John M. Haydon with violations of freedom of press and freedom of speech.

392 "Attorney Defends Charging Haydon," ADV, September 21, 1973, D-1:3.

Discusses charges filed by attorney against Gov. John M. Haydon, accusing Haydon of trying to prevent a television newsman from interviewing a trial witness during a hearing on charges that Haydon violated the Hatch Act.

393 "Haydon Sums Up Samoa Tenure," $S B A$, September 29, 1974, B-1:3.

Includes Gov. John M. Haydon's reactions to his trial on charges of violating the Hatch Act and his comments on press and broadcasting freedom.

\section{GOVERNMENT INFORMATION ACTIVITIES}

394 Greer, Richard A. "The Government of American Samoa," 3d rev. ed. Pago Pago: American Samoa Department of Education, 1958. Mimeographed. 280 pp.

Describes structure and operations of government; contains a section on public information activities, including publications and radio broadcasting. Author was superintendent of secondary education.

395 Gray, John A. C. Amerika Samoa: A History of American Samoa and Its United States Naval Administration. Annapolis: United States Naval Institute Press, 1960. 195 pp.

A history of American Samoa before and during U.S. naval administration (February 19, 1900-July 1951); some references to government publications, O Le Fa'atonu, Samoan Information Bulletin, and Failauga Samoa.

396 "Engledow Leaving for Samoa Post," $A D V$, April 26, 1968, A-7:1.

Ed Engledow named head of Office of Information in American Samoa; career brief of Engledow. 
397 “Letter from American Samoa,” $A D V$, August 24, 1971, A-11:2.

Letter from government information officer Ed Engledow responding to editorial critical of his serving as correspondent for news agencies; cites unavailability of qualified correspondents and invites private interests to enter Samoan publishing and broadcasting.

398 Engledow, Ed. "American Samoa Government Information." Paper prepared for South Pacific Editors' Conference, Suva, Fiji, July 30-August 5, 1972. Honolulu: East-West Communication Institite, 1972. 4 pp. (mimeo).

Outlines management and operations of Office of Samoan Information, publication of News Bulletin and operation of government radio; briefly summarizes implications for development of information work.

\section{LEGAL ISSUES}

399 "Governor Cited Under Hatch Act," $A D V$, July 10, 1973, A-1:7.

Reports charges before U.S. Civil Service Commission that Gov. John M. Haydon violated the Hatch Act by improper use of government radio and television in Samoan election.

400 “'Haydon Denies Vote Violations," $A D V$, July 11, 1973, A-2:5.

Reports Gov. John M. Haydon's denial of accusations he violated the Hatch Act by misusing government radio and television facilities.

401 "Trial of Haydon Starts Tomorrow," S-B, September 10, 1973, A-14:1.

Reviews background of Hatch Act charges against Gov. John M. Haydon.

402 "Election Manipulation Trial for Haydon Underway," $A D V$, September 12, 1973, B-6:4.

Background on accusations that Gov. John M. Haydon made illegal use of government radio and television facilities in connection with Samoan election.

403 “"Testimony Contradicts Gov. Haydon," $S-B$, September 12, 1973, B-2:1.

Reports testimony given by radio station reporters on alleged interference by Gov. John M. Haydon.

404 "Haydon's Statements Challenged," $S-B$, September 13, 1973, A-17:1.

Reports testimony that Gov. John M. Haydon made misleading financial statements over broadcast media and through print media.

405 "Haydon Not to Blame, 3 Testify," S-B, September 14, 1973, A-11:1.

Reports testimony from Hatch Act proceedings against Gov. John M. Haydon, including details of controversial radio program before Samoan vote.

406 “3 More Support Haydon,” $S$-B, September 15, 1973, A-3:4.

Reports testimony of three Samoan chiefs in support of Gov. John M. Haydon during Hatch Act trial.

407 "Haydon Admits Inaccuracies," $A D V$, September 19, 1973, B-8:1.

Report on proceedings of Hatch Act trial.

408 “Trial Ends, Haydon Voices Optimism," S-B, September 19, 1973, A-12:1.

Reports Gov. John M. Haydon's reactions to his trial on charges of violating the Hatch Act; notes dismissal of charges he unlawfully interfered with a television reporter trying to interview a witness at the trial.

409 "American Samoa Hatches Its Own Mini-Watergate," PIM, 44, no. 11 (November 1973): 8.

Report on proceedings against Gov. John M. Haydon for alleged misuse of government radio and television facilities. 
410 “'Radio, TV in Governor's Case,"' PICN, 4, no. 2 (December 1973): 6.

Reviews accusations that Gov. John M. Haydon misused government broadcasting facilities.

411 “The Hatch Act Hearings," Amerika Samoa, 1, no. 6 (January 1974): 15-16. Account of hearing on charge that Gov. John M. Haydon made improper use of government radio and television.

412 "Haydon Cleared," $A D V$, March 23, 1974, A-13:1.

Details of media misuse charges of which Gov. John M. Haydon was cleared.

413 “'Board Gets Haydon Ruling," $S-B$, March 25, 1974, A-13:1.

Details of ruling clearing Gov. John M. Haydon of charges he violated the Hatch Act in use of government radio and television.

414 "Chief Says Haydon Should Go,"' $S$-B, March 27, 1974, G-2:1.

Samoan chief's testimony against Gov. John M. Haydon; includes charges regarding alleged misuse of mass media.

415 “'No Hatchet for the Governor," PIM, 45, no. 5 (May 1974): 11.

Reports decision clearing Gov. John M. Haydon of charges of misusing government radio and television; background on the controversy.

\section{THE PRESS}

\section{General}

416 American Samoa. Documents in the Governor's Files in American Samoa, 1900-1949. Microfilm. 5 reels. University of Hawaii Hamilton Library.

Reels 2 and 3 contain some correspondence, reports, and newspaper clippings related to the visit, writings, and publicizing activities of Lorrin A. Thurston, owner of The Honolulu Advertiser, who visited American Samoa in 1926. Also contained is some material related to the activities of sometimes Honolulu newspaperman Arthur A. Greene, for which he was deported from American Samoa in 1920.

417 “Increased Pacific Newspaper Activity," PICN, 1, no. 2 (September 1970): $1-2$.

Reports expansion of service to Guam by Honolulu Star-Bulletin, which has options for Samoa; future of newspapers in the Pacific.

418 King, J. P. Untitled paper prepared for South Pacific Editors' Conference, Suva, Fiji, July 30-August 5, 1972. Honolulu: East-West Communication Institute, 1972.5 pp. (mimeo).

Discusses role of press under government pressure; problems of government control vs. public access to news; lack of printing equipment and trained personnel; press and public relations.

419 Bracken, Lawrence. "Government and Media in American Samoa," PICN, 4, no. 4 (September 1974): 8.

Survey of mass media in American Samoa by assistant director of government public information of fice.

\section{Fa'asamoa Pea}

420 “New Quarterly Promotes Samoan Culture," PICN, 4, no. 4 (September 1974): 9 .

Community college magazine, Fa'asamoa Pea, emphasizing preservation of Samoan culture, reviewed; editorial policy discussed. 


\section{News and Views Bulletin}

421 "Two New Papers for American Samoa," PIM, 33, no. 11 (June 1963): 71, 73.

Notes new Pago Pago publications, News and Views Bulletin, published by the Chamber of Commerce, and the Samoa News.

\section{Samoa News}

422 “Two New Papers for American Samoa," PIM, 33, no. 11 (June 1963): 71, 73.

Notes new Pago Pago publications, Samoa News, edited by Sivia F. Suria, and the News and Views Bulletin.

423 "American Samoa Gets Another New Paper," PIM, 35, no. 12 (December 1964): 65,67 .

Reports Samoa News, formerly printed in Apia, discontinued in April 1964; now publishing in Pago Pago.

424 “'Samoa Newspaper Moves," PIM, 41, no. 10 (October 1970): 109-110.

Article contains some information on Samoa News.

425 “News Plans Daily Publication,” PICN, 4, no. 1 (August 1973): 7.

Notes installation of new equipment; frequency of publication.

426 “'Tri-language Newspapers," PICN, 4, no. 1 (August 1973): 4.

Short article on Samoa News introducing articles in Tongan language in February 1973; notes other bilingual papers in the Pacific.

427 “'Samoa News Semi-Weekly,’ PICN, 4, no. 2 (December 1973): 6.

Publishing schedule (paper started semi-weekly publication in September 1973), circulation, press operations, and statement from editor of Samoa News.

428 “'Samoa News Hires Editor,” PICN, 5, no. 1 (February 1975): 11.

John Northrup is new editor of Samoa News in Pago Pago; Samoa News moved into new offices and is purchasing more equipment.

429 “ 'Samoa News Strong,' Says King," PICN, 5, no. 4 (December 1975): 18.

J. P. King, publisher of Samoa News, reports circulation increased and staff changes.

430 Ward, Jim. "The Passing of The Press," Underground Monthly, 2, no. 14 (April 1976): 33-35.

Reviews political philosophy of weekly Samoa News, which has changed over the paper's six years of existence in order to remain in business in American Samoa; notes closing of Underground Press and Samoan Sun.

\section{Samoan Sun}

431 “'Samoan Sun Sets Publication: Gallien Named Managing Editor,' PICN, 4, no. 3 (May 1974): 7.

Reviews plans for new newspaper, detailing ownership, printing, format, and competition.

432 “'Samoan Sun Due,” PICN, 4, no. 4 (September 1974): 7.

Notes planned publication of new newspaper. 
433 “'Sun Suspended," PICN, 5, no. 1 (February 1975): 11.

Samoan Sun suspends publication for one month to reorganize.

434 'Samoan Sun 'Moving In Right Direction': Gallien,' PICN, 5, no. 3 (September 1975): 8.

Article reviews Samoan Sun, now publishing on a regular basis as one of two weekly newspapers in American Samoa.

435 “'Short Takes: Press," PICN, 6, no. 2 (June 1976): 6.

Reports reaching PICN say that Samoan Sun ceased publication in February.

436 Ward, Jim. "The Passing of The Press," Underground Monthly, 2, no. 14 (April 1976): 33-35.

Article mentions that Samoan Sun and Underground Press have ceased operations in American Samoa, leaving only the Samoa News in operation.

\section{Samoa Times}

437 “American Samoa Gets Another New Paper," PIM, 35, no. 12 (December 1964): $65,67$.

Reports new weekly, Samoa Times, printed in Apia and distributed to both American and Western Samoa.

438 "'Samoa-wide Newspaper Is Created," $S-B$, May 6, 1967, B-16:3.

Announces merger of Samoa Times, Pago Pago, with Samoa Bulletin, Apia, Western Samoa; to be called Samoa Times.

439 “'Two Samoas Get Their First Joint Newspaper,'” PIM, 38, no. 6 (June 1967): 32.

Notes merger plans of Samoa Bulletin of Western Samoa and Samoa Times of American Samoa.

440 "'S-B Subsidiary Has Option to Purchase Samoa Paper," S-B, August 21, $1970,2: 1$.

Guam Publications, Inc., enters into option agreement to buy majority stock in Samoa Times.

441 “Samoa Newspaper Moves,” PIM, 41, no. 10 (October 1970): 109-110.

Discusses plans of Guam Publications, subsidiary of Honolulu Star-Bulletin, to buy majority control of Samoa Times; dispute between Samoa Times' two editors on where paper should be printed; history of the paper; some information on Samoa News.

\section{Underground Monthly (formerly Underground Press)}

442 'Sherry Gives Pago Officials A Headache,"' PIM, 46, no. 4 (April 1975): 30.

Sherry O'Sullivan has produced the first edition of Underground Monthly in American Samoa.

443 "Editorial: A Few Rarely Published Observations About American Samoa," Underground Monthly, 2, no. 14 (April 1976): 3-7.

Editor of Underground Monthly describes attack on her by Samoan women. Alleges authorities refused prompt assistance due to sensitivity of subject.

444 Ward, Jim. "The Passing of The Press," Underground Monthly, 2, no. 14 (April 1976): 33-35.

Article mentions that Samoa News is only operating paper since Samoan Sun and Underground Monthly closed. 
445 “'Underground Press Finished," PICN, 6, no. 2 (June 1976): 3.

Two-year-old Underground Press, edited by Sherry O'Sullivan, published its final issue April 15, titled Underground Monthly. Article reviews editor's comments about leaving American Samoa.

\section{RADIO BROADCASTING}

446 Roberts, Quincy F. "When the Bug Bit in Samoa," Radio Broadcast, 3 (October 1923): 471-76.

447 “'Village Receivers for E. Samoa," PIM, 24, no. 3 (October 1953): 100.

Reports transmitter unused since U.S. Navy relinquished control of American Samoa being used again; notes plans to issue receivers to villages.

448 “Pacific Broadcast Changes," PIM, 25, no. 5 (December 1954): 143.

Reports changes in island broadcasting, including a note on daily local news broadcasts of WVUV, Pago Pago.

449 “'Broadcasting in the Pacific," $S P B, 6$, no. 4 (October 1956): 41-45, 56.

Describes broadcasting facilities in American Samoa and other island areas.

450 “'Berger Firm Gets Samoa Station: Commercial Radio," $A D V$, April 23, 1973, A-14:1.

Organization headed by Honolulu broadcaster signs contract for taking over American Samoa's radio station, WVUV.

451 McMillan, Michael. "American Samoa-Radio Samoa WVUV Begins NonGovernment Operation," PICN, 4, no. 1 (August 1973): 6-7.

Describes plans for lease of government radio station to private commercial firm (reprinted in $A B U$, July 1973).

452 “WVUV Delay," PICN, 4, no. 2 (December 1973): 6.

Reports delay in transfer of government radio station to private operation.

453 “"WVUV Stoned Off the Air," PICN, 4, no. 4 (September 1974): 9.

Radio station's noisy power generator annoys neighbors, who retaliate with rocks.

454 “'Radio for Samoa," S-B, March 5, 1975, A-18: 1.

FCC approves Radio Samoa, Ltd., a Honolulu-based management team, to operate radio station WVUV in American Samoa.

455 “'Selling a Radio Station to Raise the Wind," PIM, 46, no. 5 (May 1975): 70.

Government of American Samoa needs to raise more revenue and so is negotiating lease for Radio Samoa.

456 “'Pago's WVUV Goes to Private Control," PICN, 5, no. 2 (June 1975): 4.

Radio station WVUV has been in private operation since early 1975; article reviews lease considerations.

\section{SATELLITE COMMUNICATION}

See also Pacific Islands General

457 Hunter, Pat. "PEACESAT In New Role," $A D V$, May 24, 1973, D-2:1.

Article reviews first experimental two-way conference via PEACESAT with public health nursing personnel in American Samoa. 
458 "American Samoa." PEACESAT Project. Social Applications: Early Uses of International Two-Way Communications by Satellite for Social Development. Report Two. Honolulu: University of Hawaii PEACESAT Project. October 1975. pp. 59-65.

Includes interviews with Dr. Peter Beales, director of public health in American Samoa, and Steve Eigsti, a television engineer, on the importance of rapid communication between Pacific Islands for public health and other social measures.

\section{TELEVISION}

459 “TV Brings Trade to a Standstill," PIM, 35, no. 11 (November 1964): 63.

On the interest of Samoans in television programs.

460 “American Samoa Gets It Live,” PIM, 42, no. 6 (June 1971): 95.

Notes live broadcast of Flag Day celebration by KVZK-TV.

461 “Who's Boss in American Samoa?" PIM, 45, no. 12 (December 1974): 15-16. Reports censorship of a film showing on television by Gov. John M. Haydon.

462 "TV Controversy in America Samoa: Censorship Issue," PICN, 5, no. 1 (February 1975): 10.

Article reviews incident on September 24, 1974, when Gov. John M. Haydon stopped a film from being shown on Pago Pago television. 


\section{Cook Islands}

INDEXES, GUIDES, REFERENCE WORKS

463 Coppell, William G. “The Moss Papers," Journal de la Société des Océanistes, XXVIII, no. 36 (September 1972): 285-304.

Describes the content of the papers of Frederick J. Moss (1829-1904), held by the library of the Auckland Museum and Institute. Moss was British Resident in the Cook Islands, 1890-98. Includes references to the operations of the newspapers Ioi Karanga and Te Torea.

\section{NEWSPAPERS, PERIODICALS}

464 COOK ISLANDS GAZETTE. Rarotonga. 1898-1919, 1921-26, 1958-. Official gazette.

465 COOK ISLANDS NEWS. Rarotonga. 195? - . Published five times weekly in English and Maori.

466 COOK ISLANDS PHOTO NEWS. Rarotonga. February 15, 1975-. Published weekly in English.

467 COOK ISLANDS REVIEW. Rarotonga. December 1954-61, 1967-70. First monthly, then bimonthly in English and Maori.

468 WEEKENDER. Rarotonga. 1974-. Published weekly. Irregular.

\section{GOVERNMENT AND INTERNATIONAL AGENCY REPORTS}

469 New Zealand. Department of Island Territories. Cook Islands Annual Report. Wellington, 1891-1965. Title varies. 


\section{EDUCATION AND TRAINING OF COMMUNICATORS}

470 McBain, Norman. "Training in the Pacific," $A B U$, no. 100 (January 1974): 27-28.

Report on broadcast training courses sponsored by Unesco and the South Pacific Commission conducted in the Cook Islands and elsewhere in 1973.

\section{EDUCATIONAL MEDIA}

471 Thornton, Jack. "School Journals for Polynesia," PIM, 22, no. 9 (April 1952): 66-67.

Describes production by School Publications Branch, New Zealand Education Department, of literature for distribution in Western Samoa, Cook Islands, Niue, and Tokelau Islands; deals with editing, production, and distribution.

472 “'Radio Rarotonga Goes on the Air,” PIM, 25, no. 2 (September 1954): 159.

Reports initiation of weekly shortwave broadcasts programmed by Further Education Office.

473 Davies, F. R. J. “'School Broadcasts for Cook Islands,'” PIM, 26, no. 12 (July 1956): 99.

Letter to editor explaining educational broadcasting situation; points out absence of organized program and lack of money.

474 “'No More Money for Cook Islands Broadcasts,"' PIM, 31, no. 1 (August 1960): 119.

Reports lack of funds for educational broadcasts.

475 Coppell, William G. "Development and Education in the Cook Islands: A Study of Community and Development in an Emergent Pacific Islands Territory.", Ph.D. thesis. University of Southhampton. 1968. 559 pp.

Examines the function of education in relation to contemporary development problems of the Cook Islands and illustrates educational principles involved in the emergent territories of the Pacific; refers to role of mass media.

476 South Pacific Commission. Regional Training Seminar of Educational Broadcasting: Report and Recommendations. Noumea: South Pacific Commission, 1970. $105 \mathrm{pp}$.

Report on a conference at Suva May 20-June 2, 1970; includes discussion of status of educational broadcasting, recommendations regarding authority and operations, language teaching, use in schools, teacher training, and community education; summarizes papers based on experiences in the Cook Islands, Fiji, and Papua New Guinea.

477 Hayden, Howard. “'On the Quality of Education in the South Pacific,' International Review of Education, 27, no. 2 (1971): 165-81.

A survey of South Pacific education systems and their problems; some references to educational radio in the Cook Islands.

\section{THE PRESS}

478 “'European Electors' Meeting in Rarotonga," PIM, 18, no. 5 (December 1947): 31-32, 34.

Story concerning Legislative Council contains six paragraphs of discussion in support of establishing a newspaper and a broadcasting station in the Cook Islands. 
479 Cormack, James E. "Rarotonga Was Like That in the Nineties," PIM, 19, no. 6 (January 1949): 43-44.

Article on Rarotonga of the 1890 s contains two paragraphs on the origins of two newspapers, $T e$ Torea and Ioi Karanga.

480 “New Cook Islands Newspaper," PIM, 25, no. 4 (November 1954): 163.

Reports plans of Cook Islands administration to publish a new monthly journal in addition to an existing publication dealing with history and culture.

481 “Ins and Outs of Newspaper Publication," PIM, 25, no. 6 (January 1955): 134.

Reports selection of Cook Islands Review as name for new publication.

482 “Cook Islands Have a Newspaper,” PIM, 25, no. 7 (February 1955): 33.

Two-paragraph item notes first issue of Cook Islands Review, published in English and Maori.

483 “'Cook Islands News Now Carries Photos,' PIM, 30, no. 1 (August 1959): 81. Three paragraphs note the beginning of publication of local photographs in the Cook Islands News.

484 “'A Financial Future for 'Cook Islands News',” PIM, 31, no. 10 (May 1961): 118.

Reports increased charge by government to subscribers of Cook Islands News.

485 "Cook Islands Paper Comes Out of Hibernation," PIM, 38, no. 3 (March 1967): p. 20.

Notes resumption of publication of Cook Islands Review, a monthly magazine, by the Department of Social Development; had been suspended since 1961.

486 Haas, Anthony. "Three Years After Internal Self-Government: The Cook Islands General Election 1968,' Journal of Pacific History, 4 (1969): 136-145.

References to use of mass media-radio and the Cook Islands News-in the 1968 election campaign.

487 Coppell, William G. "Cook Islands History is Buried in Its Lost Newspapers," PIM, 42, no. 3 (March 1971): 81, 83.

Short history of newspapers in the Cook Islands.

488 Mahutariki, Marii. "Cook Islands News Still Going," $P I C N, 4$, no. 2 (December 1973): 8.

489 Coppell, William G. "When Newspapers Waged War in the Cooks." PIM, 45 , no. 2 (February 1974): 57-59.

Reviews earliest Cook Islands commercial newspapers, such as Te Torea, which was published in the 1890 s.

490 “A Thorn in Sir Albert's Side,” PIM, 45, no. 4 (April 1974): 15-16.

Discusses new newspaper, Democratic News, published by the opposition political party.

491 “'Picture Paper in The Cooks,” PIM, 46, no. 5 (May 1975): 19.

Article about Weekly Roundup of News in Pictures, new publication by government of Cook Islands.

492 “Photo News," PICN, 5, no. 2 (June 1975): 3.

Cook Islands government sponsors weekly tabloid, Cook Islands Weekly Roundup of News in Pictures; tourist oriented. 
493 "Weekender Appears in Cook Islands," PICN, 5, no. 2 (June 1975): 3.

A mimeographed weekly, the Weekender, published in the Cook Islands. Coverage is heavily political and the paper is reportedly put out by the Democratic Party.

494 “'Cook Islands Weekly 'Bites' Back,” PICN, 5, no. 3 (September 1975): 8.

Some quotes from Cook Islands Weekender, an opposition newspaper.

\section{RADIO BROADCASTING}

495 “'Cook Islands Notes,” PIM, 1, no. 2 (September 1930): 9.

Brief reference to the number of radio receivers in use.

496 “"Radio Popular in Cook Islands," PIM, 2, no. 1 (August 1931): 12.

Reports number of radio receiver licenses issued.

497 "News for Islands: Increasing Use of Radio," PIM, 3, no. 2 (September 1932): 23.

Notes increasing use of radio receivers in the Cook Islands.

498 “'Radio License Fee in Cook Islands," PIM, 8, no. 8 (March 1938): 47.

Complaints about radio receiver license fees.

499 '"European Electors' Meeting in Rarotonga," PIM, 18, no. 5 (December 1947): 31-32, 34.

Describes meeting to discuss matters to be put before Legislative Council; includes discussion in support of establishing a newspaper and broadcasting station.

500 “'Radio Innovation for Cook Islands," PIM, 23, no. 7 (February 1953): 127.

Reports use of idle aircraft radio navigation beacon to rebroadcast Radio New Zealand Christmas program of special interest to Cook Islanders.

501 “Rarotonga Wants a Local Broadcasting Station," PIM, 24, no. 5 (December 1953): 62 .

Reports Legislative Council discussion favoring establishment of a small broadcasting station.

502 “Cook Islands Plans for Radio Broadcasts,” PIM, 24, no. 11 (June 1954): 39.

Reports beginning of test broadcasts with shortwave transmitter by Cook Islands administration.

503 "Faint and Jammed: Cook Is. Get Poor Radio Broadcasts," PIM, 24, no. 11 (June 1954): 66.

Describes poor reception of Radio New Zealand service intended for Pacific Islands.

504 “'Radio Rarotonga Goes on the Air," PIM, 25, no. 2 (September 1954): 159.

Notes initiation of weekly shortwave broadcasts programmed by the Further Education Office.

505 "Rarotonga Broadcasts on New Frequency," PIM, 25, no. 3 (October 1954): 151.

Short note on test broadcasts.

506 Brown, J. Edward. "Cook Islands' Nerve Centre Today is Radio Rarotonga," PIM, 26, no. 3 (October 1955): 80, 97-98.

Deals mostly with point-to-point communication but contains some information on distribution of news bulletins and limited use of transmitter for broadcasts. 
507 “'Broadcasting in the Pacific.”' SPB, 6, no. 4 (October 1956): 41-45, 56.

Describes broadcasting facilities in Cook Islands and elsewhere.

508 “Nearly All-Maori Radio Staff," PIM, 29, no. 7 (February 1959): 141.

Notes that Cook Islands radio system employs only two Europeans; also information on sub-stations and revenue.

509 "Broadcasting Station Urged for Cooks," PIM, 30, no. 1 (August 1959): 131.

Cook Islands Legislative Council advocates establishment of a broadcasting station.

510 “They'll Make Their Own Transistors," PIM, 31, no. 2 (September 1960): 125.

Reports the establishment of the Cook Islands Radio Manufacturing Cooperative Society, Ltd., which plans to make low-cost transistor receivers.

511 Muir, T. “'Radio Cook Islands,” $S P B, 13$, no. 3 (July 1963): 34-36.

History of radio in the Cook Islands; describes current services and equipment.

512 Haas, Anthony. "Three Years After Internal Self-Government: The Cook Islands General Election 1968," Journal of Pacific History, 4 (1969): 136-45.

References to use of mass media, including radio, in the 1968 election campaign.

\section{SATELLITE COMMUNICATION}

See also Pacific Islands General

513 “PEACESAT News Exchange a Reality,' Cook Islands News, June 27, 1974, p. 4.

Reports start of News Exchange in Cook Islands.

514 “G.E.I.C., New Hebrides Visit PEACESAT Station,” Cook Islands News, July 3, 1974.

515 "'South Pacific Festival of Arts 'Use of Peace Satellite'," Cook Islands News, October 15, 1975, p. 8.

Describes use of satellite to reduce administrative bottlenecks in South Pacific Festival of Arts in 1976.

516 '"South Pacific Festival of Arts 'Further Use of PEACESAT'," Cook Islands News, October 15, 1975, p. 8.

Exercise on PEACESAT organized by Tony Hanley at Wellington Polytechnic, New Zealand; will be repeated two more times in 1975.

517 "'Photo News Views PEACESAT Efforts," PICN, 5, no. 4 (December 1975): 15.

On August 16, Cook Islands Photo News reviewed benefits from PEACESAT programs and their effects on the Cook Islands.

\section{TELEVISION}

518 “Pago TV Picked Up In Rarotonga," PIM, 36, 1 (January 1965): 37.

Reports reception of television broadcasts from American Samoa. 


\section{Easter Island}

\section{TELEVISION}

519 "TV Comes to Easter Island; Will It Ever Be the Same?" $S-B$, January 25 , 1975, A-12:2.

Chile's State TV Company opened a station in Hango Roa, to provide 2 hours of daily (pretaped) television. Previously, only media available was the showing of some U. S. movies to residents by the U. S. military, which operated a base on Easter Island from 1966 to 1970. 


\section{Fiji}

\section{INDEXES, GUIDES, REFERENCE WORKS}

520 Diamond, A. I. "The Central Archives of Fiji and the Western Pacific High Commission," Journal of Pacific History, 1 (1966): 204-11.

Describes holdings of the archives, which include extensive collections of official publications and $\mathrm{Fi}$ jian newspapers.

521 Fiji. Central Archives of Fiji and the Western Pacific High Commission. "Catalogue of Microfilm-Archives Series," rev. and enlgd. Suva, 1970. 4 pp.

522 "Catalogue of Microfilm-Library Series," rev. and enlgd. Suva, 1975. $31 \mathrm{pp}$.

523 Serial Publications of Fiji: Non-government. Compiled by L. S. Qalo. Suva, 1970.22 pp.

524 Serial Publications of the Government of Fiji, rev. and enlgd. Compiled by S. Baksh. Suva, 1970. 16 pp.

525 Fiji. National Archives. "List of Newspapers in the Library of the Central Archives and in the Sir Alport Barker Memorial Library on the 30 September 1964." 6 pp. Mimeo.

526 Handbook of Fiji, 4th ed. Sydney: Pacific Publications, 1972. 264 pp.

527 University of the South Pacific. Library. Pacific Collection Accessions List. Quarterly since March 1976.

528 Wilcox, Dennis L. English Language Newspapers Abroad: A Guide to Daily Newspapers in 56 Non-English-Speaking Countries. Detroit: Gale Research Co., 1967. 
NEWSPAPERS, PERIODICALS

529 BULlETIN DU VICARIAT (de Fiji). Suva. June 1891-August 1894. Published by the Vicariate Apostolic of the Fiji Islands. Available on microfilm, Pacific Manuscripts Bureau.

530 DUISIGA. Suva. May 1, 1951-October 30, 1952. Weekly. Incomplete microfilm available at Fiji Central Archives; University of Hawaii.

531 ECHO. See Fiji Film and Photo News.

532 FIJI ARGUS: AN INDEPENDENT JOURNAL DEVOTED TO THE INTERESTS OF FIJI. Levuka. July 24, 1874-1884? Weekly. Microfilm (incomplete) available at Fiji Central Archives.

533 FIJI BEACH PRESS. Suva. February 1969-. Semimonthly in English. Published by Beach Press Ltd.

Although tourist-oriented, has occasional criticisms of tourism and articles on social issues.

534 FIJI CATHOLIC GAZETTE. See Sacred Heart Cathedral Gazette.

535 FIJI FILM AND PHOTO NEWS. Suva. 1972-75. Published by Fiji Times \& Herald. Incorporates Echo (197?-72).

536 FIJI GAZETTE. See Fiji Royal Gazette.

537 FIJI GAZETTE AND CENTRAL POLYNESIAN. See Fiji Royal Gazette.

538 FIJI GUARDIAN. Suva. September 1947-December 7, 1957. Weekly. Available on microfilm at Fiji Central Archives.

539 FIJI HOLIDAY. Suva. 1968-. Monthly in English. Published by Fiji Times \& Herald Ltd. Incorporates Ni Bula Mai (September/October 1968-April 1970), which was published monthly in Fijian. Tourist information.

540 FIJI INFORMATION. Suva. August 15, 1975-. Biweekly in English issued by Ministry of Information. Supersedes News from Fiji (1946-July 1975), generally issued biweekly by Fiji Public Relations Office.

541 FIJI NATION. Suva. April 1969-April 1973. Biweekly in Fijian and English. Official organ of the Alliance Party. Fijian title: Na Tovata. Title varied: Fiji Nation Newsmagazine.

542 FIJI NATION NEWSMAGAZINE. See Fiji Nation.

543 FIJI PHOTO NEWS. See Radio Preview.

544 FIJI ROYAL GAZETTE. Suva. October 12, 1872-. Official gazette published weekly. Titled varied: Fiji Gazette and Central Polynesian (1871?-October 1872), available on microfilm at Library of Congress; Fiji Gazette (October 12, 1872-October 1874), available at University of Hawaii and Library of Congress. Available on microfilm (1874-1910, 1944-46) at University of Hawaii and (1944-46, 1969-72) at New York Public Library. 
545 FIJI SAMACHAR. Suva. 1923-February 26, 1976. Weekly in Hindi. Microfilm (1937-1950) available at Library of Congress.

546 FIJI SANDESH. Suva. 1974-75. Weekly.

547 FIJI SPORT. Suva. June 1970-76. Monthly in English. Published by Fiji Times \& Herald Ltd.

548 FIJI SUN. Suva. 1974-. Daily. Published by Newspapers of Fiji Ltd.

549 FIJI TIMES. Suva. September 4, 1869-. Daily in English. Title varied: published from 1932 to February 29, 1956, as The Fiji Times And Herald, incorporating the Western Pacific Herald, Fiji Times, and Suva Times. The original Suva Times (October 29, 1881-December 29, 1886) was weekly from 1881 to June 1883, semiweekly from July 1883 to 1886 . The daily Western Pacific Herald (April 13, 1901-May 18, 1918) merged with Fiji Times on May 20, 1918. The Western Herald (1974), published in Lautoka, and the Pacific Weekender (1975), both weeklies and published by the Fiji Times and Herald Ltd., were incorporated into the Fiji Times.

Copies of Suva Times (October 29, 1886-December 1886) are held at the State Library at Victoria, in Melbourne, Australia. Copies of the Western Pacific Herald (April 13, 1901-December 1906) are held at the Mitchell Library, in Sydney; and incomplete copies (April 13, 1901-1918) are held in State Library of Victoria, in Melbourne; also available in Fiji Central Archives. Microfilm of Fiji Times available at University of Hawaii Library and Fiji Central Archives (1869-).

550 THE FIJI TIMES AND HERALD. See Fiji Times.

551 FIJI TOURIST GAZETTE. Suva. 192? Issue of July 1928 available on microfilm. Pacific Manuscripts Bureau.

552 FIJI VRITANT. Suva. April 1976-. Monthly in Hindi.

553 FIJI WOMAN AND HOME. Suva. October 1970-September/October 1971. Monthly.

554 FIJIAN WEEKLY NEWS AND PLANTERS' JOURNAL. Levuka, Fiji. August 8-November 21, 1868. Microfilm available at Fiji Central Archives.

555 I TUKUTUKU. Suva. November 1975-. Monthly in Fijian.

556 JAGRITI. Nadi. 1951-76. Triweekly in Hindi.

557 JAI FIJI. Lautoka. February 1959-. Weekly in Hindi. National Library of Australia, Parkes, A. C. T., has files.

558 NAI LALAKAI. Suva. March 2, 1962-. Weekly in Fijian. National Library of Australia, Parkes, A. C. T., has files.

559 NA MATA. Suva. January/February 1970-. Monthly in Fijian, published by Government of Fiji. Earlier editions: September 1876-December 1890 (irregularly); January 1891-December 1969 (monthly). State Library of Victoria, Melbourne, has incomplete collection (September 1876-1971). 
560 NA TOVATA. See Fiji Nation.

561 NEWS AND VIEWS. Lautoka. 1955-? Published monthly by Fiji Red Cross Society, Lautoka Branch. Frequency varied.

562 NEWS FROM FIJI. See Fiji Information.

563 NI BULA MAI. See Fiji Holiday.

564 OCEANIA DAILY NEWS. Suva. 1948-49. Daily in English. Superseded Weekly Guardian.

565 PACIFIC REVIEW. Suva. 1949-December 1974. Weekly in English and Fijian. Fijian title: Vakalelewa Ni Pasifika. Issues (1963-1968) available on microfilm at University of Hawaii. Complete microfilm set available at Fiji Central Archives.

566 PACIFIC WEEKENDER. See Fiji Times.

567 POVAI. Suva. November 1975-. Published bimonthly in English, and occasional articles in French, Maori, and other Pacific Island languages, by the Pacific People's Action Front.

568 RADIO PREVIEW. Suva. 1968-73. Monthly in English. Incorporated Fiji Photo News.

569 SACRED HEART CATHEDRAL GAZETTE. Suva. August 1936-July 1952. Monthly. Official organ of the Vicariate of Fiji; published August 1950 to July 1952 as Fiji Catholic Gazette. Available on microfilm, Pacific Manuscripts Bureau.

570 SHANTI DUT. Suva. 1935-. Weekly in Hindi. Published by Fiji Times \& Herald Ltd. National Library of Australia, Parkes, A. C. T., has issues from July 1955.

571 SOUTH SEAS WEEKLY. Suva. 1926-47. Weekly in English. State Library of South Australia, Adelaide, has imperfect collection (December 6, 1926-September 26, 1942). State Library of Victoria, Melbourne, has imperfect collection (October 10, 1924-September 19, 1942). Selection of items from the Fiji Times.

572 SUNDAY NEWS. Suva. August 28, 1960-1961. Weekly.

573 SUVA TIMES. See Fiji Times.

574 VAKALELEWA NI PASIFIKA. See Pacific Review.

575 VANUA. Suva. July/August 1976-. Bimonthly newsletter of the Native Land Board Trust.

576 VOLAGAUNA. Suva. January 1953-October 1975. Fijian language. Frequency varied: weekly (1953-60); semiweekly (1961-66); weekly (1966-75). Available on microfilm at University of Hawaii.

577 WEEKLY GUARDIAN. See Oceania Daily News.

578 WEEKLY NEWSLETTER. Suva. May 17, 1942-December 28, 1956. On microfilm in Fiji Central Archives.

Typescripts of radio broadcasts published by government public relations office. 
579 WESTERN HERALD. See Fiji Times.

580 WESTERN PACIFIC HERALD. See Fiji Times.

581 WESTERN PACIFIC HIGH COMMISSION GAZETTE. Suva. 1915-67. Issues of 1940-42 available on microfilm at University of Hawaii.

Publication contained ordinances, administrative changes, etc., for Great Britain's Pacific Colonies: New Hebrides, Gilbert and Ellice Islands, Fiji, British Solomon Islands.

\section{GOVERNMENT AND INTERNATIONAL AGENCY REPORTS}

582 Fiji Broadcasting Commission. Annual Report. 1955-.

Reports cover the activities of the year 1954 and on, include staff, training, programming, news and current affairs broadcasting, technical facilities, international contracts, advertising and finances.

583 Fiji. Broadcasting Review Committee. The Report of the Broadcasting Review Committee, 1969/70, under the Chairmanship of Desmond M. Taylor, together with a Report on the Fiji Radio Audience Survey, June-September 1969, under the Direction of Brian P. Emmett. Suva: Government Printer, 1970. 16 pp. Appendices.

Reviews history of radio broadcasting in Fiji and criticisms of programming, languages used, structure, personnel and their performance. Arguments on the possibility of television in Fiji are summarized. Statistical analysis of large sample of radio listeners used variables such as urban/rural, ethnic background of listener, educational level, ability to speak English, etc.

584 Fiji. Parliamentary Papers. Department of Post and Telecommunications Report.

Annual report to Government of Fiji; reviews statistics on telephone and radio use.

585 Fiji. Printing and Stationery Dept. Publications Bulletin. Suva. August 1952October 1971. July 1972-. Quarterly.

\section{CINEMA}

586 Olkowski, Dennis A. "Fiji's Cinema Use Varied," PICN, 6, no. 2 (June 1976): 4,8 .

According to 1975 market survey conducted by the Fiji Times, most adult males living in the country's urban centers attend at least one movie a week. Article reviews movie attendance in Fiji, as well as the Ministry of Information's programs for producing and showing educational and developmental films in rural areas.

\section{COMMUNICATION RESEARCH}

587 Lee, John. "International News Flow in the Expatriate English-Language Press," Journalism Quarterly, 42, no. 4 (Autumn 1965): 632-38.

Fiji Times included among thirty newspapers in study.

588 "'Survey of Government Control of Media," PICN, 2, no. 2 (August 1971): $1-4$.

Summarizes findings of a survey of leaders' attitudes toward mass media conducted by Ralph Barney.

589 Rural Broadcast and Farm Press Survey. Suva: Ministry of Agriculture, Fisheries and Forests, May 1973. 24 pp.

Survey of about 250 Fijian and Indian farmers to determine newspaper reading and radio listening patterns. Variables included radio ownership, hours of listening, most useful farming programs, age groups listening preferences, and similar variables for newspaper use. 
590 Barney, Ralph D. "Mass Media Roles in Development: A Descriptive Study from Four Developing Areas," Gazette, 19, no. 4 (1973): 222-38.

A study of the developmental news content of six Pacific Island newspapers, including the Fiji Times; content analysis produced little evidence of systematic inclusion of development-oriented material in any of the six.

591 Survey of Newspaper Purchase and Readership. Fiji. 1975. Suva: Fiji Times and Herald, Ltd. $1975.20 \mathrm{pp}$.

A study done for the Fiji Times; contains statistics on regularity of purchase of daily newspapers, purchasing habits of other publications, demographic characteristics for newspaper readers.

\section{EDUCATION AND TRAINING OF COMMUNICATORS}

592 Agar, T. C. "Training Broadcast Technicians in Fiji," $S P B, 10$, no. 4 (October 1960): 64-65.

Describes training conducted by Fiji Broadcasting Commission.

593 McBain, Norman. "Extensive Training for Asian Broadcasters," $A B U$, no. 89 (October 1972): 17-21.

Short-term training in basic radio production and presentation organized by Unesco and Asian Broadcasting Union.

594 Watts, Frank. "ABC Activities in the Training of Overseas Educational Broadcasters," Educational Broadcasting International, 6, no. 3 (September 1973): 145-47.

Describes training programs conducted by Australian Broadcasting Commission, 1967-1972; trainees from Fiji and other Pacific Islands areas.

595 "Radio, TV News Training Discussed on PEACESAT," PICN, 4, no. 2 (December 1973): 5-6.

Training for radio and television news personnel discussed on three teleconferences held OctoberDecember among participants from Fiji and elsewhere.

596 McBain, Norman. "Training in the Pacific," $A B U$, no. 100 (January 1974): 27-28.

Report on broadcast training courses sponsored by Unesco and the South Pacific Commission conducted in Fiji and elsewhere in 1973.

597 “'Training for Printers," PICN, 5, no. 2 (June 1975): 5.

Article reprinted from Fiji National Training Council, Training News of April 1975. The Council's School of Printing recently completed two courses in linotype keyboard operating and bookbinding - paper handling and guillotine operating.

598 "Fiji Broadcaster at EWCI as Intern," PICN, 5, no. 3 (September 1975): 5.

Lasarusa Vusoniwailala, a broadcaster from Suva, joins the East-West Communication Institute as a professional development intern.

599 "PINA Plans Training Scheme with USP, Fiji Council," PICN, 5, no. 3 (September 1975): 7.

Plans being made for pilot training project sponsored by Pacific Islands News Association in cooperation with the University of the South Pacific and the Fiji Training Council. 


\section{EDUCATIONAL MEDIA}

600 “School's In! On the Coconut Radio," PIM, 32, no. 12 (July 1962): 91-92.

Discusses educational programs directed to Fiji classrooms.

601 South Pacific Commission. Regional Training Seminar on Educational Broadcasting: Report and Recommendations. Noumea: South Pacific Commission, 1970. $105 \mathrm{pp}$.

Report on a conference at Suva May 20-June 2, 1970; includes discussion of educational broadcasting, recommendations regarding authority and operations, language teaching, use in schools, teacher training, and community education; summarizes papers based on experience in Fiji, Papua New Guinea, and the Cook Islands.

602 De Young, J. E. "Regional Training Seminar on Educational Broadcasting, Suva, May 20 to June 2, 1970," SPB, 20, no. 4 (1970): 41-42.

Report on South Pacific Commission training seminar.

603 Haydon, Howard. "On the Quality of Education in the South Pacific," International Review of Education, 27, no. 2 (1971): 165-81.

Reports that with few exceptions, international exploration of educational development has by-passed the South Pacific. Reviews educational systems in major island groups.

604 Mansfield, Norma. "School Broadcasts in Teaching English as a Second Language," Educational Television International, 5, no. 5 (December 1971): 265-68.

Treats some technical aspects of language instruction by radio, including advantages and disadvantages, suitability of material, and techniques, based on experience in Fiji.

605 Johnstone, Ian. "The Widening Sphere of the SPC's Work and Influence," $A B U$, no. 91 (January 1973): 7-10.

Discusses the South Pacific Commission Training Seminar on Educational Broadcasting held in Suva in 1971 and its recommendations; explains recent changes in SPC Radio Bureau.

\section{FREEDOM OF THE PRESS/BROADCASTING}

606 “Fiji Indian Newspaper Suppressed,” PIM, 13, no.12 (July 1943): 35.

Reports enforced suspension of Fiji Samachar on charges of fomenting opposition to prosecution of war.

607 “Press Bill Creates Slight Stir in Fiji," PIM, 19, no. 8 (March 1949): 9.

Reports enactment by Fiji government of a bill requiring newspapers to print corrective statements whenever the Governor in Council considers an item published was false or distorted.

608 “Fiji's Press Bill Has Easy Passage," PIM, 19, no. 9 (April 1949): 26.

Reports approval of Press Correction Bill.

609 “Ignorant Indians Cause a Press Explosion," PIM, 23, no. 7 (February 1953): 57.

Describes incident in which an Indian member of Suva Town Council entered Fiji Times office and attempted to edit a report on Council debate to his own satisfaction; notes an increase in attempts to influence the newspaper. 


\section{GOVERNMENT INFORMATION ACTIVITIES}

610 Robson, R. W. "Notes Made in and Around Fiji," PIM, 26, no. 6 (January 1956): 25, 125-27, 129.

Includes comment on running criticism of Fiji government public relations officer published in local newspaper.

611 “South Pacific Governments and Their Press Relations," PIM, 27,

no. 3 (October 1956): 17-18.

An editorial contrasting government public relations offices of Fiji (good) and Papua New Guinea (bad); says Papua New Guinea officials use public relations office as shelter; criticizes sensational and distorted journalism.

612 "Role of Information Service in Independent Fiji," PICN, 3, no. 1 (July 1972): 6 .

Subjective approach to media services in Fiji, written by Luke Waqa, government information officer.

613 “Information Services, Department of Agriculture." Suva: Fiji Government, 1973. 2 pp.

A government release outlining the aims and goals of the Media Extension Office; gives programming information.

614 “Government Agencies Adding Information,” PICN, 4, no. 3 (May 1974): 8.

Lists private and government agencies in Fiji appointing public relations officers; jobs attracting trained journalists, causing shortage in newspaper staffs.

615 “20 Fiji Civil Servants Attend Public Relations 'Crash' Course," PICN, 4, no. 4 (September 1974): 10.

Describes training and a five-day government information services seminar, including three recommendations.

616 “'Ratu David Toganivalu to Information Ministry,'” PICN, 5, no. 1 (February 1975): 14.

Former minister without portfolio named to head new Fiji Information Ministry, previously an information department.

617 Nand, G. R. “Report on Four to Savusavu." Suva: Ministry of Information, August 8, 1975. 2 pp.

A document outlining a month-long tour by the Ministry of Information mobile film unit in the northern island of Vanualevu.

\section{LEGAL ISSUES}

618 Robson, R. W. "Patience is Most Necessary If You Are Charged With Libel on Fiji," PIM, 27, no. 10 (May 1957): 24, 131, 133.

Account of trial of R. W. Robson on charges of libeling writer Jack Thornton in Robson's defense of a Fiji public relations officer, published in July 1956; judgment rendered in favor of Thornton for 10 pounds.

619 . “Fiji and Fiji's Supreme Court,”'PIM, 27, no. 11 (June 1957): 23.

Reports Robson's decision to appeal judgment in Thornton libel case.

620 "Journalist Deported from Fiji," The Times (London), November 19, 1957, $10: 5$.

Reports deportation of J. E. Thornton. 
621 Robson, R. W. "Thornton Deported from Fiji," PIM, 28, no. 5 (December 1957): 133.

Reports deportation of writer Jack Thornton; discusses Fiji immigration laws re Thornton; reviews libel suit against Robson and notes dropping of appeal.

\section{NEWS AGENCIES}

622 “Beach Press Moves," PICN, 4, no. 2 (December 1973): 8.

Notes change in facilities for several newspapers published in Suva, as well as for the South Pacific Area News Service (SPANS).

\section{THE PRESS}

\section{General}

623 A'Beckett, Arthur W. "The Colonial Press," Proceedings of the Royal Colonial Institute, 38 (1906-1907): 54-91.

Lists Fiji and New Guinea newspapers but deals mainly with those in Australia, New Zealand, and Canada.

624 “Another Newspaper and Radio for Lautoka?" PIM, 26, no. 7 (February 1956): 121.

Cane growers announce plans to start newspaper at Lautoka and to apply for radio broadcasting license.

625 “New Fiji Newspaper Company," PIM, 36, no. 4 (April 1965): 133.

Notes formation of Pacific Daily, Ltd., a company organized in Suva to do business as newspaper proprietors.

626 Derrick, R. A. A History of Fiji. Suva: Government Printing Office, 1968. 250 pp.

General history to 1874 with brief references to early newspapers; first published in 1946 and revised in 1950.

627 “Independence News Coverage," PICN, 2, no. 1 (February 1971): 6-7.

Discusses role of mass media in Fiji during granting of independence.

628 Meller, Norman, and James Anthony. Fiji Goes to the Polls: The Crucial Legislative Council Elections of 1963. Honolulu: East-West Center Press, 1968. 185 pp.

An account of the conduct of the election; discussion of the use of newspapers and radio.

629 Gandhi, Nat. "The Survival of a Language Seen as Vital to Racial and Cultural Solidarity in a Plural Society." Paper prepared for South Pacific Editors Conference, Suva, Fiji, July 30-August 5, 1972. Honolulu: East-West Communication Institute, 1972. 4 pp. (mimeo).

The propagation of Hindi in Fiji is vital to the survival of racial and cultural solidarity in Fiji's plural society. Information on Fiji's Hindi population presented.

630 Grimes, Paul. "Reporting from Abroad." Paper prepared for South Pacific Editors Conference, Suva, Fiji, July 30-August 5, 1972. 9 pp.

Points out similarities between Fijian newspapers and those of United States' cities that are insular in nature and show little interest in news outside their region. 
631 Vusoniwailala, Lasarusa. "The Free Press in a Multi-racial Society: Fiji, A Case Study." Unpublished student paper presented at University of Hawaii, December 1975. 18 pp.

Reviews structure of the radio and press in Fiji, particular social structure problems of the two dominant cultures, and the responsibility of the "free press" in either assisting or hindering national development; illustrated by examples of press irresponsibility. Condensed version, titled "Responsibility in Fiji Press," appeared in PICN, 6, no. 2 (June 1976).

\section{Duisiga}

632 Tudor, Judy. "Duisiga: Fiji Language Newspaper is Established," PIM, 22, no. 3 (October 1951): 41 .

Notes appearance of the first Fijian-language weekly newspaper.

633 “Newspaper for Fijians," PIM, 23, no. 7 (February 1953): 34.

Notes demise of Duisiga a year earlier.

\section{Fiji Beach Press}

634 “'Beach Press Moves," PICN, 4, no. 2 (December 1973): 8.

Notes change in facilities for Fiji Beach Press, Hosting \& Purchasing Magazine, and South Pacific Area News Service.

635 “'Fiji Beach Press Gets New Offset,” PICN, 5, no. 2 (June 1975): 6.

News (South Pacific) Ltd. installed a six-unit Polygraph offset machine. It produces the Fiji Beach Press and the monthly Hosting and Purchasing.

\section{Fiji Guardian}

636 “Fiji Guardian: A Newly Weekly Newspaper," PIM, 18, no. 1 (August 1947): 14.

Reports plans for publication of a new weekly newspaper at Suva.

637 “'New Fiji Newspaper,” PIM, 18, no. 2 (September 1947): 60.

Reports delay in publication of first issue of Weekly Guardian, Suva.

638 “'Weekly Guardian: A New Newspaper in Fiji," PIM, 18, no. 2 (September 1947): 16.

Critical review of first issue of newspaper; describes difficulties of getting started.

639 “"Weekly Guardian and Electors' Association," PIM, 18, no. 3 (October 1947): 78.

Letter to the editor from the managing editor of the Weekly Guardian disclaiming connection of newspaper with the European Electors' Association reported in an earlier issue of Pacific Islands Monthly.

\section{Fiji Police Magazine}

640 “"The Fiji Police Magazine,” PIM, 31, no. 8 (March 1961): 93.

Describes a magazine produced by the Fiji police.

\section{Fiji Samachar}

641 “Fiji Indian Newspaper Suppressed,” PIM, 13, no. 12 (July 1943): 35.

Announced Indian-language newspaper suppressed by Government of Fiji by order of Defense Regulations in April 1943. 


\section{Fiji Sun}

642 "Hollywood TV Star Joins Forces with NZ Publisher to Launch Fiji Daily," National Business Review, 4, no. 17 (May 29, 1974).

Reviews plans for establishment of Fiji Sun; emphasis on stockholders.

643 “Group Plans October Debut for Fiji P.M.” Editor \& Publisher, 107, no. 23 (June 8, 1974): 16.

Announcement of new Fiji daily, Fiji Sun, starting publication in October.

644 “New Fiji Daily Planned," PICN, 4, no. 4 (September 1974): 10.

Reports plans for publication of daily tabloid, Fiji Sun.

645 “Changes with Islands Press,” PIM, 45, no. 11 (November 1974): 10.

Includes information on Fiji Sun and Sunday Sun.

646 Survey of Newspaper Purchase and Readership. Fiji. 1975. Fiji Times and Herald, Ltd. 1975. 20 pp.

Statistical study of characteristics of readers of Fiji Times and Fiji Sun. Other tables include: Regularity of purchase of daily newspapers; purchasing habits of other publications.

647 “'Birth of A Newspaper," Fiji Sun, January 25, 1975, 8.

Many special articles under this heading describing activities and personnel of Fiji Sun.

648 “Getting The Paper From A to Z," Fiji Sun, January 25, 1975, 8.

Reviews coordination between editorial, advertising, and production departments.

649 “Fiji Daily, Sunday, Weekly Papers Start: Pacific Review Suspended," PICN, 5, no. 1 (February 1975): 12.

New daily, the Fiji Sun, an afternoon tabloid produced in Suva by Newspapers of Fiji, Ltd., also producers of the new Sunday paper, Sunday Sun.

650 Fiji Sun Market Report. July 1975. Suva: Coopers \& Lybrand, Chartered Accountants. August 1975. 20 pp.

Report contains audited circulation breakdown by areas; independent readership survey. Statistics are provided for each day of the month, including by city. Readership survey provides information on race, employment, type of occupation of readers, income, which of two largest newspapers is preferred for news, sports coverage, etc.

651 “'From a Staff of 15 to 124,"' Fiji Sun, July 1, 1975, 22.

Article in special supplement to Fiji Sun.

652 “When It Was Only in English," Fiji Sun, July 1, 1975, 21.

Article in special supplement to Fiji Sun.

653 “Fiji Daily Editor: 'Tide Turns' for Sun," PICN, 6, no. 1 (June 1976): 4.

Sun Associate Editor Mark Ebrey comments on recent financial success of paper, which emphasizes "entertainment and information."

\section{Fiji Times}

654 "Jubilee for Fiji Newspaper and Fiji Knight," PIM, 21, no. 10 (May 1951): 116.

On the knighthood of Alport Barker and the golden anniversary of the Western Pacific Herald. 
655 “Sir Alport Barker's Fiji Times, ” PIM, 26, no. 4 (November 1955): 18.

Reports talks on possible purchase of Fiji Times, changes in facilities and personnel.

656 Robson, R. W. "Fiji Has Front Seat View of Irresponsible Journalism," $P I M, 26$, no. 5 (December 1955): 19, 21-22.

Editorial criticizing news coverage of abandoned ship incident in which Fiji Times alleged the ship's crew was murdered.

657 “Fiji Times Purchased by Pacific Publications," PIM, 26, no. 8 (March 1956): 19.

Announces purchase; gives short history.

658 “Fiji Times Becomes Morning Daily," PIM, 26, no. 10 (May 1956): 18.

Reports change May 1, 1956, to morning publication and dropping of Herald from paper's name.

659 “The Fiji Times: Mr. L. G. Usher Takes Over," PIM, 27, no. 5 (December 1956): 22.

On appointment of L. G. Usher as executive director of Fiji Times and Herald, Ltd.

660 "Perhaps Tonga Could Earn the Honour," PIM, 29, no. 1 (August 1958): 35.

Reports plan of Fiji Times to adopt slogan "The First Newspaper Printed in the World Today" and plans of Tongan government to publish a new newspaper closer to the international dateline.

661 "Stop Press," PIM, 29, no. 5 (December 1958): 29.

Notes Fiji Times's new banner, "The First Newspaper Published in the World Today."

662 "A Newspaper on Tapa Cloth," PIM, 29, no. 7 (February 1959): 144.

Reports discovery of a copy of February 21, 1911, issue of Fiji Times printed on tapa cloth.

663 "More Printing-Publishing Service for Growing Territories," PIM, 30, no. 4 (November 1959): 19.

On the merger of South Pacific Post, Ltd., Papua New Guinea publishers, and Pacific Publications Printing, Ltd., publisher of Shanti Dut and Fiji Times in Suva.

664 Usher, Len G. "History of Fiji Times," Transactions and Proceedings of The Fiji Society, 9, no. 1 (1962): 55-66.

Sketches history of Times from 1869 , including leading personalities of the paper at key periods; some information on printing methods and plant.

665 "Expansion for Fiji Times and Herald," PIM, 37, no. 8 (August 1966): 145.

Reports paper's plans to build larger facilities; some general information about the paper's circulation and growth.

666 "One Hundred Years Old and Still Going Strong," PIM, 40, no. 7 (July 1969): 35.

Anniversary of Fiji Times.

667 "It's Been Microfilmed for Posterity," PIM, 40, no. 9 (September 1969): 49.

Notes plans for microfilming of the Fiji Times.

668 “Our First 100 Years," Fiji Times, September 4, 1969.

Centennial supplement.

669 “Newspaper in Fiji Marks 100 Years," $N Y T$, September 14, 1969, 16:5.

On anniversary of Fiji Times. 
670 “'Wilke Buys Into 'PIM' and 'The Fiji Times' Group,” PIM, 41, no. 7 (July 1970): 20, 127-28.

Reports purchase by Wilke and Co., Ltd., Sydney, of 40 percent of ordinary shares of Pacific Publications, Ltd., Sydney; gives short histories of the companies; information on stock value.

671 Usher, Len. "The Fiji Times Newspaper Group."' Paper prepared for the South Pacific Editors Conference, Suva, Fiji, July 30-August 5, 1972. Honolulu: East-West Communication Institute, 1972. 7 pp.

672 Cranfield, C. A. "A History of the Fiji Times, 1869-1875." M.A. thesis, University of Newcastle, 1973. 166 pp.

Reviews the background and establishment of the Fiji Times; economic problems of the planters and how this was covered in the Times; relations between settlers and Fijians; politics revealed in the Times during annexation and cessation periods.

673 Fogel, Howard H. "Fiji Islands Greet Each Day With World's First Daily," Editor \& Publisher, 107, no. 23 (June 8, 1974): 16, 18.

Descriptive article on Fiji Times operations and facilities.

674 Survey of Newspaper Purchase and Readership. Fiji. 1975. Fiji Times and Herald, Ltd. 20 pp.

Statistical study of characteristics of readers of Fiji Times and Fiji Sun. Other tables include: Regularity of purchase of daily newspapers; purchasing habits of other publications.

675 “'Melbourne Herald Publisher Buys Fiji Times, Associated Papers," PICN, 5, no. 1 (February 1975): 12.

Controlling interest in the Fiji company sold to Herald and Weekly Times, Ltd., of Melbourne, in October 1974; some management changes made.

676 “'Murrant Resigns Fiji Times Post,” PICN, 5, no. 4 (December 1975): 13.

November resignation of Jim Murrant, general manager of Fiji Times and Herald, Ltd., announced.

\section{Fijian Weekly and Planters Journal}

677 Wall, Colman C. “' 'The Fijian Weekly News \& Planters Journal,' or Fiji Over Fifty Years Ago," Transactions of the Fijian Society (1922): 12-16.

Resume of the contents of the Fijian Weekly News \& Planters' Journal, published at Suva, August to November 1868.

\section{Indian Times}

678 "Another Indian Newspaper: Plurality of Journals to Air Political Views,", PIM, 16, no. 3 (October 1945): 17.

Notes appearance of Indian Times, a monthly in English and Hindustani; about half of article deals with Indian views of Fiji sugar industry.

\section{Nai Lalakai}

679 “'Fiji Has A New Newspaper," PIM, 32, no. 8 (March 1962): 19, 20.

Notes appearance of the Fijian-language Nai Lalakai.

\section{News and Views}

680 Tudor, Judy. “'Bringing the News to Fiji," PIM, 25, no. 9 (April 1955): 140.

Reports efforts of a group of Lautoka, Fiji, women to produce a mimeographed newspaper, News and Views; compares news situation in Fiji and New Guinea. 


\section{Oceania Daily News}

681 “New Daily Newspaper in Fiji," PIM, 18, no. 8 (March 1948): 20.

Notes the appearance in Suva of morning Oceania Daily News in March, an outgrowth of the Weekly Guardian (1947-48).

682 “Fiji Morning Newspaper Ceases Publication," PIM, 19, no. 10 (May 1949):

9.

Reports the cessation of Oceania Daily News because of labor problems.

\section{Pacific Review}

683 “Fiji Daily, Sunday, Weekly Papers Start; Pacific Review Suspended," PICN, 5, no. 1 (February 1975): 12.

Reports suspension of Pacific Review.

\section{Povai}

684 “New Leftist Periodical Begins Publishing in Suva," PICN, 5, no. 4 (December 1975): 7.

Povai, a new Pacific opinion periodical designed for a regional audience, appeared in November, published by Pacific Peoples' Action Front.

\section{Sail Ho}

685 “'Sail Ho," PIM, 15, no. 8 (March 1945): 24.

Short notice of publication by the Fiji government information office of a news magazine called Sail $H o$ for the people of the Gilbert and Ellice Islands.

\section{Shanti Dut}

686 "More Printing-Publishing Service for Growing Territories," PIM, 30, no. 4 (November 1959): 19.

Reports the merger of South Pacific Post, Ltd., Papua New Guinea publishers of the twice-weekly South Pacific Post and the weekly New Guinea Times-Courier, with Pacific Publications Pty. Ltd., who publish Pacific Islands Monthly in Sydney and Shanti Dut and the Fiji Times in Suva.

\section{Star of the Pacific}

687 “'Tropicalities," PIM, 15, no. 6 (January 1945): 9.

Article mentions magazine published in Suva from 1908 titled Star of the Pacific.

\section{Talanoa}

688 "First Talanoa Was Produced by a Bishop, A Priest and A Bricklayer," PIM, 29 , no. 6 (January 1959): 25.

Short history of Marist mission newspaper, A Talanoa, printed by Loreta Press, July 1892 to 1954.

\section{Volagauna}

689 “Newspaper for Fijians,” PIM, 23, no. 7 (February 1953): 34.

Notes appearance of Volagauna, weekly newspaper in Fijian, and demise of Duisiga about one year earlier.

690 “Volagauna To Close," Fiji Times, October 17, 1975, 3.

Economic pressures and drop in sales caused decision to close paper; one of oldest Fijian-language papers in country. 


\section{Western Herald}

691 "Fiji Daily, Sunday, Weekly Papers Start; Pacific Review Suspended," PICN, 5, no. 1 (February 1975): 12.

The Western Herald, weekly, introduced by the Fiji Times group.

\section{PRESS/BROADCASTING ORGANIZATIONS}

692 "Fiji Fourth Estate's Uplift Club," PIM, 42, no. 7 (July 1971): 28.

Reports formation of Fiji press club; discusses some problems of reporters in a multi-lingual society.

693 “'Hindi Journalists Form,” PICN, 4, no. 2 (December 1973): 8.

Reports formation of Hindi Journalists Union.

\section{PRINTING}

694 O'Reilly, Patrick. Imprints of the Fiji Catholic Mission including the Loreto Press, 1864-1954. London: Francis Edwards, Ltd., 1958. 60 pp.

Sketches the history of the publishing activities of the Marist mission; includes annotated list of publications.

695 Gribble, R. L. "Printing in Fiji," Transactions and Proceedings of The Fiji Society, 9, no. 2 (1963): 130-43.

Reviews missionary and church presses, commercial and government printing history.

\section{RADIO BROADCASTING}

696 "Islands Broadcasting: Plans by A. W. A.," PIM, 5, no. 10 (May 1935): 5.

Cites reports that Amalgamated Wireless (Australasia) might start a radio station at Suva.

697 “Is It Farewell to Beach Wireless?” PIM, 5, no. 12 (July 1935): 55.

Report on negotiations between Fiji government and A. W. A. to improve service; notes reports of planned establishment of a Fiji Broadcasting Company.

698 "Fiji Radio: New Arrangements with A. W. A.," PIM, 6, no. 1 (August 1935): 4.

Reports completion of negotiations for government of Fiji to take over internal telegraph service from Amalgamated Wireless (Australasia), which will operate a broadcasting service.

699 "Radio Stations for Pacific: Broadcasts from Suva and Pt. Moresby," PIM, 6, no. 3 (October 1935): 28.

Preparations almost complete at Suva station.

700 "Powerful Radio Station for Suva," PIM, 6, no. 5 (December 1935): 8.

Short note on Amalgamated Wireless official's statement of plans for a radio station at Suva.

701 "Station ZJV," PIM, 6, no. 8 (March 1936): 66.

Reports completion of construction of ZJV.

702 “Fiji's New Broadcasting Station," PIM, 6, no. 9 (April 1936): 66.

Fiji correspondent describes criticism of new Suva station.

703 "Suva Radio Station Officially Opened by Colonial Secretary," PIM, 6, no. 9 (April 1936): 37.

On the opening of $\mathrm{ZJV}$. 
704 “'Suva's New Broadcast Station,” PIM, 7, no. 3 (October 1936): 54.

Improvements at Amalgamated Wireless station in Suva.

705 "Big Broadcasting Station to be Placed in Suva as Empire Link," PIM, 8, no. 5 (December 1937): 5.

Reports plans of Amalgamated Wireless for a worldwide broadcasting service from Suva.

706 “Fiji Broadcast: Interest of Native Children," PIM, 9, no. 2 (September 1938): 45.

Fiji children reported curious about radio; includes editorial comment on the ill effects of radio.

707 "Radio for Fijians: Broadcasts of News and Concerts," PIM, 9, no. 4 (November 1938): 32.

Background of R. H. Lester and his programs in Fijian on station ZJV, Suva.

708 “'Radio Licenses in Fiji," PIM, 20, no. 3 (October 1949): 75.

Notes total of 1,874 radio receiver licenses in Fiji in 1948, almost equally divided between the residents of Suva (972) and country residents (902).

709 “'New Broadcasting House for Suva," PIM, 22, no. 1 (August 1951): 127.

Reports approval of plans for new studio and office building for the proposed Fiji Broadcasting Commission.

710 “Broadcasting Commission," PIM, 22, no. 2 (September 1951): 114-15.

On plans to have a Fiji Broadcasting Commission succeed Amalgamated Wireless.

711 “Broadcasting Commission Plans Take Shape Slowly," PIM, 22, no. 10 (May 1952): 135 .

Describes progress in construction of new facilities and change over from Amalgamated Wireless control to new broadcasting commission.

712 "Some Doubts About the Fiji B'csting Commission," PIM, 23, no. 4 (November 1952): 93.

Describes Legislative Council debate on bill to establish Fiji Broadcasting Commission.

713 “Suva Tests on Short-Wave Radio,” PIM, 23, no. 8 (March 1953): 58.

Notes tests from Suva; roundup of shortwave broadcasting in the South Pacific.

714 “'Short Wave Radio,” PIM, 23, no. 9 (April 1953): 99.

Notes use of new frequencies for broadcasts from Suva.

715 “ZJV Has Troubles,” PIM, 23, no. 11 (June 1953): 80.

Discusses tests to find suitable frequency for shortwave coverage of the islands.

716 “Fiji Broadcast Services Extended," PIM, 24, no. 1 (August 1953): 83.

ZJV extends broadcasting hours.

717 “Fiji's New Broadcasting Policy,” PIM, 24, no. 1 (August 1953): 99.

Reports Fiji Broadcasting Commission decision to use commercial programs to help pay expenses.

718 “Changes in Island Broadcasts," PIM, 24, no. 3 (October 1953): 87.

Roundup of frequency changes for shortwave broadcasts in several areas, including Fiji. 
719 "First Manager of Fiji Broadcasting Commission," PIM, 24, no. 4 (November 1953): 47.

Notes appointment of K. G. Collins as manager of Fiji Broadcasting Commission.

720 Fiji Broadcasting Commission. Annual Report. 1955-.

Report covers the activities of the year 1954 and on; includes staff, training, programming, news and current affairs broadcasting, technical facilities, international contracts, advertising and finances.

721 "Extension of Broadcasting When FBC Take Over in July," PIM, 24, no. 9 (April 1954): 33.

On progress in development of Fiji Broadcasting Commission and plans for service.

722 “New Broadcasting Station for Fiji: Very Modern Installation," PIM, 24, no. 10 (May 1954): 19.

Reports completion of Fiji Broadcasting Commission building.

723 “'Status of Fiji's New Broadcasting House," PIM, 24, no. 11 (June 1954): 16.

Fiji Broadcasting Commission facility to open July 1; comments of commission chairman.

724 "Fiji Broadcasting Commission in Control," PIM, 25, no. 1 (August 1954): 19.

Reports formal initiation of broadcasting under control of the Fiji Broadcasting Commission and from its new facilities.

725 “No More Cheap Listening in Fiji," PIM, 25, no. 5 (December 1954): 123.

Reports a campaign to enforce radio receiver licensing regulations.

726 "Pacific Broadcast Changes," PIM, 25, no. 5 (December 1954): 143.

Changes in the weekly news broadcast conducted by the Fiji Public Relations Office.

727 "Broadcasting in Fiji: Pleasing Some of the People Some of the Time," PIM, 25, no. 7 (February 1955): 73.

Fiji correspondent reports varying views of the programming of VRH, the new Fiji Broadcasting Commission station, during its first six months.

728 "Tri-Lingual Radio Service is Costly in Fiji," PIM, 25, no. 9 (April 1955): 135.

Discussion of programming costs; based on Fiji Broadcasting Commission annual report.

729 “Improvement to Fiji's News Broadcasts," PIM, 26, no. 2 (September 1955): 126.

Reports expansion of local news programs by Fiji Broadcasting Commssion.

730 “Improving Fiji Radio News Service," PIM, 26, no. 4 (November 1955): 71.

On the expansion of news broadcasts by the Fiji Broadcasting Commission.

731 "Lautoka Broadcast Station in 1956," PIM, 26, no. 4 (November 1955): 107.

New Fiji Broadcasting Commission transmitter to be installed at Lautoka to relay programs from Suva.

732 "Another Newspaper and Radio for Lautoka?" PIM, 26, no. 7 (February 1956): 121.

Reports plans of cane growers association to start newspaper and apply for broadcasting license. 
733 “'MLC's Will Use Radio Appeals to Electors," PIM, 27, no. 10 (May 1956): 22.

Fiji Broadcasting Commission agrees to make time available free to candidates for Legislative Council.

734 “'Better Radio Service in Fiji,’’ PIM, 26, no. 11 (June 1956): 102.

Notes plans of Fiji Broadcasting Commission to install new transmitter at Lautoka to improve services.

735 “'Fiji No Longer Hears the ABC 9 O'clock News," PIM, 27, no. 1 (August 1956): 20.

Fiji Broadcasting Commission discontinues rebroadcast of Australian Broadcasting Commission evening news programs because of complications with press agencies.

736 “A ‘Smithy' Man for Suva Post,” PIM, 27, no. 4 (November 1956): 135.

Reports appointment of John Stannage as manager of Fiji Broadcasting Commission.

737 “'Fifteen Thousand Unlicensed Radios," PIM, 28, no. 3 (October 1957): 165.

Reports government threats to enforce receiver license fee requirements; 15,664 licenses issued with an estimated 30,000 sets in use.

738 “'British Government is Fiji Radio's Santa Claus," PIM, 28, no. 5 (December 1957): 101 .

Based on annual financial report of Fiji Broadcasting Commission; gives total expenditures and revenues; discusses license fees.

739 “'Fiji's Mr. Hall Is a Busy Man,’ PIM, 29, no. 1 (August 1958): 77, 79.

On radio licensing inspector and his efforts to track down unlicensed radios.

740 “New Transmitters for Fiji Broadcasting," PIM, 30, no. 5 (December 1959): 121.

Describes efforts to improve Fiji broadcasting service through two new 10-kilowatt transmitters, expected to be in operation in 1961 .

741 Stannage, J. S. "Radio Broadcasting in Fiji," Presidential Address-1960, Transactions and Proceedings of The Fiji Society, 8 (1960): 3-9.

Article stresses importance of various radio broadcasting services; detailed history of Fijian radio broadcasting; statistics provided.

742 “New Broadcasts From Fiji and Tarawa," PIM, 30, no. 10 (May 1960): 127. Notes new English-language broadcast outlet in Fiji.

743 Fiji's Radio Correspondent,"' PIM, 32, no. 8 (March 1962): 25.

Comment on objectivity of the Australian Broadcasting Commission.

744 “'Radio Entertainment and Advertising,” PIM, 32, no. 10 (May 1962): 25.

Reports letter from T. McCready, of Lautoka, Fiji, concerning advertising and listener licenses on Fiji radio.

745 “Fiji's Broadcasting Service Pays Its Way," PIM, 32, no. 11 (June 1962): 23.

I. M. Hedstrom, Chairman of Fiji Broadcasting Commission, disputes information on Fiji radio given in a letter to the editor in May 1962; provides financial information about Fiji radio. 
746 Peck, D. G. "Telecommunications in Fiji," Transactions and Proceedings of The Fiji Society, 9, no. $2(1962 / 1963)$ : 144-56.

Reviews history of telephone and radio services in Fiji.

747 Lawn, Victor H. "Radio in the Fijis-Commercials and All," NYT, July 21, 1963, II, 11:5.

Discusses facilities and programming of Fiji Broadcasting Commission.

748 Belshaw, Cyril. Under the Ivi Tree: Society and Economic Growth in Rural Fiji. Berkeley: University of California Press, 1964. 336 pp.

Chapter deals with communication problems related to rural development, especially with radio and telecommunication; other scattered references to radio.

749 “Ban On Tobacco Advertising," PIM, 35, no. 6 (June 1964): 49.

Reports decision of Fiji Broadcasting Commission to ban cigarette commercials from radio.

750 Meller, Norman, and James Anthony. Fiji Goes to the Polls: The Crucial Legislative Council Elections of 1963. Honolulu: East-West Center Press, 1968. 185 pp.

An account of the conduct of the election with some discussion of the use of newspapers and radio.

751 “Mayday! Mayday! Come In Mayday!” PIM, 40, no. 5 (May 1969): 55.

Describes Radio Suva, its broadcasts and coverage area.

752 Fiji. Broadcasting Review Committee. The Report of the Broadcasting Review Committee, 1969/70, under the Chairmanship of Desmond M. Taylor, together with a Report on the Fiji Radio Audience Survey, June-September 1969, under the Direction of Brian P. Emmett. Suva: Government Printer, 1970. 16 pp. Appendices.

Reviews history of radio broadcasting in Fiji and criticisms of radio programming, languages used, structure, personnel and their performance. Arguments about possible introduction of television to Fiji are summarized. Statistical analysis of large sample of radio listeners used variables such as urban/rural, ethnic background of listener, educational level, ability to speak English, etc.

753 "Less English for Fiji Radio-And No Television," PIM, 41, no. 3 (March 1970): 32 .

Interview with Desmond Taylor, chairman of Broadcasting Review Committee, which held hearings on various questions relating to reorganization of Fiji broadcasting; does not give content of Committee's report.

754 “New Way to Tax Fiji Radio Sets," PIM, 41, no. 4 (April 1970): 143.

Reports proposal that government tax each radio sold rather than continue the radio listeners' tax; the 40,000 licenses current believed to represent only part of the sets in use.

755 Fiji Broadcasting Commission. "Independence Celebrations in Fiji," $A B U$, no. 68 (December 1970): 16-18.

Discusses Fiji Broadcasting Commission coverage of Fijian independence day. Reprinted in PICN, 2, no. 1 (February 1971):6-7.

756 “Fiji Beach Radio," PICN, 2, no. 2 (August 1971): 7.

Brief note on establishment of a visitor-oriented closed-circuit radio system in Fiji hotels. 
757 Cockcroft, John. "Broadcasting From the Centre of the South Pacific," $A B U$, no. 80 (January 1972): 40-42.

Short history of Fiji Broadcasting Commission; information on problems of operating for a multilingual population and on staff training.

758 Cockcroft, John. "Profile: George Williams, Journalist F.B.C." $A B U$, no. 80 (January 1972): 50-51.

Interview with the assistant news editor of the Fiji Broadcasting Commission on radio service in Fiji.

759 Fiji Broadcasting Commission. "Profile: John Hunt, General Manager, FBC," $A B U$, no. 83 (April 1972): 42-44.

Interview with John Hunt on improvements planned for Radio Fiji.

760 “'Getting Bounce Into Radio Fiji,” PIM, 43, no. 5 (May 1972): 83.

Discusses plans for reduction of English-language programming and establishment of separate networks for programming in Fijian and in Hindi.

761 Leonard, Hugh. "Radio is a Way of Life for Fiji's Teenagers," $A B U$, no. 84 (May 1972): 34-36.

On Radio Fiji's efforts to program for younger people; information on the listening preferences of young Fijians.

762 Hunt, John. "Broadcasting in Fiji," SPB, 23, no. 2 (1973): 29-31.

Article reviews development of use of three languages (English, Fijian, and Hindi) in radio programming in Fiji, plus new technical developments and activities. Condensation of article in $A B U$, no. 100 (January 1974): 31-32.

763 “Fiji Radio Adopts New Advertising Policy," PICN, 4, no. 1 (August 1973): 8.

Outlines advertising policy, with emphasis on use of jingles and standards of good taste; sales statistics.

764 “'What Lies Ahead for Radio Fiji?" Fiji Times, October 26, 1973.

Article in Supplement to Fiji Times on the anniversary of the Fiji Broadcasting Commission.

765 "Broadcasting Mix Changed," PICN, 4, no. 2 (December 1973): 8.

Synopsis of nineteenth annual report of the Fiji Broadcasting Commission.

766 “FBC Appoints First Development Officer," PICN, 4, no. 2 (December 1973): 9.

Details of role of Fiji Broadcasting Commission development officer; background of appointee, Ambika Maharaj.

767 “No More Ads At News Time-FBC,” Fiji Times, December 6, 1974.

Fiji Broadcasting Commission has scrapped advertisements sponsoring news bulletins on a six-month trial basis because of criticism by Prime Minister.

768 “'Your Guide to Radio," Fiji Sun, January 25, 1975, pp. 8-9.

A supplement to the Fiji Sun included article on Fiji Broadcasting Commission.

769 “Government Backs Broadcasting Loan," PICN, 5, no. 1 (February 1975): 12.

Fiji Government guarantees $\$ 50,000$ loan for Fiji Broadcasting Commission to finance new transmitting station at Drasa, Lautoka, and replace equipment. 
770 “'Government, Media Dispute Flares,” PICN, 5, no. 1 (February 1975): 14.

Article detailing dispute between Fiji government officials and the Fiji Broadcasting Commission. The government suggests it may start its own broadcasting service; a Fiji Times editorial characterizes suggestion as dangerous.

771 Williams, George. "Radio Fiji Meets The Storm Head-on," $A B U$, no. 112 (February 1975): 13-14.

Article reviews procedures Radio Fiji's two networks use during hurricanes, such as during Hurricane Val in January.

772 “'Speech Therapist Joins Radio Fiji,” PICN, 5, no. 3 (September 1975): 5.

English speech therapist, Mary Pernetta, is new Fiji Broadcasting Commission radio personality.

773 Olkowski, Dennis. “Radio: Fiji Farms,” PICN, 6, no. 1 (March 1976): 7, 10.

Article describes radio broadcasting use for promoting agricultural development in Fiji.

\section{SATELLITE COMMUNICATION}

See also Pacific Islands-General

774 “'Pacific Network for Satellite," PICN, 2, no. 2 (August 1971): 16-17.

Describes preparations for PEACESAT terminals at Suva and in Papua New Guinea.

775 Cutting, Alan, and David A. Berkowitz. Peacesat Report 1972. Suva: University of the South Pacific. 1972. 22 pp.

Report on the progress of experiment in international education communications at University of South Pacific. Reviews PEACESAT project development, ground station details, PEACESAT exchanges, use in classrooms, individual person-to-person exchanges, and evaluation.

776 “'Radio Link," PIM, 43, no. 3 (March 1972): 29.

Reports Carnegie Foundation grant for experimental satellite link between Fiji and Hawaii.

777 “Lessons Swap by Satellite," PIM, 43, no. 9 (September 1972): 26.

On PEACESAT experiments.

778 Creamer, Beverly. "PEACESAT Has Been A Learning Experience," S-B, October 10, 1972, A-15:1.

Reviews person-to-person exchanges of PEACESAT satellite system.

779 Arvidson, K. O. "The University of the South Pacific," Education News, 14, no. 1 (February 1973); 18-22.

Describes activities and development of University of the South Pacific; brief references to participation in PEACESAT project.

780 Morse, Harold. "First UH-to-Fiji Satellite Link Is Successful," $S$ - $B$, February 3, 1972, A-10.

Reviews first test of UH-to-Fiji satellite communication and upcoming activities.

781 "UH Establishes Satellite Contact with Suva, Fiji," $A D V$, February 3, 1972, E-4.

Article highlights first satellite link between University of Hawaii and Suva.

782 "Radio, TV News Training Discussed on PEACESAT," PICN, 4, no. 2 (December 1973): 5-6.

Reports three tele-conferences held in October-December, for discussing training needs and methods for radio and TV news personnel. 
783 White, Margaret. "USP to Add 8 Satellite Terminals," PICN, 4, no. 2 (December 1973): 1.

Describes plans and reviews University of South Pacific-University of Hawaii PEACESAT project.

784 "SPC and USP to Share Base Communications Work," PICN, 4, no. 3 (May 1974): 6.

Describes regional media center at University of the South Pacific, Suva, combining the University, the South Pacific Commission, and satellite projects.

\section{5 “'Work to Start on Satellite Receiver," PICN, 4, no. 3 (May 1974): 8.}

Describes plans for satellite receiver station for international telecommunications and possible television relays.

786 Benstead, Gilda, Dick Northcott, and Peter McMechan. Report for the first experimental year: USP satellite communication project. University of the South Pacific, Extension Services. April 1975. 56 pp.

Review of USP involvement in satellite project. Goal of project was to determine the applicability of two-way voice and data communication to the Extension Services program of USP; ten ground terminals planned. Details given on stations and evaluation of programs.

787 Usher, Len. "Satellite Over the Pacific: An Experiment in Public Service Communication." Pacific Islands News Association in Association with the Extension Services of the University of the South Pacific. Suva. June 1975. 7 pp.

Reviews status of satellite projects in Pacific. Pacific Regional News Exchange briefly explained.

788 Fong, Alison. "Satellite Brings Islands Closer," Fiji Sun, July 22, 1975, 6:1.

Reviews PEACESAT-USP satellite system and recent educational programs using system.

789 "Three-nation Link Opens Satellite Station: Boost for Communications," Fiji Information, 2, no. 11 (May 21, 1976): 1, 7-9.

Article reviews opening of Cable and Wireless Ltd. satellite earth station near Suva; comments of Governor-General of Fiji.

\section{TELEVISION}

790 “First The Set-Then TV (Maybe),” PIM, 29, no. 10 (May 1959): 117.

Notes importation of television sets by Fiji firm; plans to experiment with reception from Australia.

791 “TV For Suva-Maybe Later, Not Yet," PIM, 29, no. 11 (June 1959): 141-42.

Discusses problems of bringing television to Suva.

792 "How Long Will The Islands Keep Television at Bay?" PIM, 30, no. 7 (February 1960): 15.

Reception of Australian television signals reported by Suva resident.

793 "Australia Firm Still Interested in Fiji Television," PIM 35, no. 3 (March 1964): 122-23.

Notes plans of Electronic Industries, Ltd., of Australia to build two television transmitters in Fiji with signals strong enough to reach Western Samoa and part of Tonga.

794 “TV Company Registered in Fiji,” PIM, 35, no. 4 (April 1964): 123.

Fiji Television, Ltd., applies for license to operate a commercial television station. 
795 “No Television for Fiji-Yet," PIM, 35, no. 6 (June 1964): 121-22.

Reports Fiji government's decision that Fiji is not ready for television.

796 “'Fiji Should Have Television ('But Not The Commercial Kind')," PIM, 40, no. 1 (January 1969): 31.

Report on a study to determine the feasibility of television in Fiji and the future of radio; includes specific recommendations.

797 “Less English for Fiji Radio-And No Television," PIM, 41, no. 3 (March 1970): 32 .

Interview with Desmond Taylor, chairman of Broadcasting Review Committee, which held hearings on reorganization of Fiji broadcasting.

798 “Work to Start on Satellite Receiver," PICN, 4, no. 3 (May 1974): 8.

Reports construction of a satellite receiver station for international telecommunications and possible television relay.

799 "Ratu Mara Discusses TV in Honolulu Talk," PICN, 5, no. 3 (September 1975): 3 .

Prime Minister of Fiji discusses need for electrification and other matters before the introduction of TV to Fiji.

800 Vusoniwailala, Lasarusa. "TV or Not TV?" Impulse (Winter 1976): 25-26.

Reviews problem of commercialism in American TV as compared to Britain's BBC, with conclusion that a BBC-type structure and philosophy of operation would have more potential for developing countries, such as Fiji. 


\section{French Polynesia}

\section{INDEXES, GUIDES, REFERENCE WORKS}

801 O'Reilly, Patrick. Tahitiens: Répertoire bio-bibliographique de la Polynésie Française. Supplément. Publications de la Société des Océanistes, no. 17. Paris: Musée de l'Homme, 1966. 103 pp.

802 and Edouard Reitman. Bibliographie de Tahiti et de la Polynésie Française. Publications de la Société des Océanistes, no. 14, Musée de l'Homme. Paris. 1967. 1046 pp.

Historical reference for periodicals published in French Polynesia.

803 and Raoul Teissier. Tahitiens: Répertoire bio-bibliographique de la Polynésie Française, 2nd ed. Publications de la Société des Océanistes, no. 36. Paris: Musée de l'Homme, 1975.670 pp.

Includes some printers and publishers; an earlier edition appeared in 1962 as no. 10 in the same series.

804 Taillemite, Étienne. "Inventaire du Fonds Océanie (Polynésie française) conservé aux archives du Ministère de la France d'Outre Mer,' Journal de la Société des Océanistes, 15 (1959): 267-320.

\section{NEWSPAPERS, PERIODICALS}

805 ALLO TAHITI. Papeete. February 8-15, 1974—. Weekly in French.

Television guide distributed with Les Nouvelles.

806 L'AMI DES TAHITIENS. Uturoa, Raiatea. January 1903-1909? Monthly in French and Tahitian.

807 TE ARA O OTEANIA. Papeete. December 1952-May 1956. Weekly, then bimonthly in French and Tahitian. 
808 TE ARA'TAI. Papeete. May 1947-September 1963. Irregular in Tahitian. Title varied; also known as: Bulletin du Comité Pouvanaa; Bulletin du Rassemblement démocratique des populations tahitiennes; Organe du Rassemblement; Organe de liaison du Rassemblement; Périodique d'information publié par le Rassemblement.

809 BULLETIN. See Tahiti, Les Nouveaux Objectifs.

810 BULLETIN COMMERCIAL. Papeete. 1907-? Monthly bulletin in French.

811 BULLETIN OFFICIEL DES ÉTABLISSEMENTS FRANÇAIS DE L'OCÉANIE. Papeete. November 1847-June 1860. Monthly official gazette.

812 LE CANARD TAHITIEN. Papeete. December 1963-? Weekly in French.

813 LA CLOCHE. Papeete. May 1886-1887. Monthly, then bimonthly in French.

814 LA CONCIERGE. Papeete. March to July 1954. Frequency undetermined. In French.

815 COURRIER DE TAHITI. Papeete. August 1906-November 1909. Irregular in French.

816 LE COURRIER DES E. O. F. January 1949-April 1951. Published twice a week in French.

817 LES DÉBATS. Papeete. February 1958-September 1962. Weekly in French.

818 LES DÉBATS LIBÉRÉS. Papeete. August-October 1962. Weekly in French.

819 LA DEPECHE DE TAHITI. Papeete. August 1964-. Daily except Sunday in French. (La Dépêche started when La Presse de Tahiti ceased.) Available on microfilm, Pacific Manuscripts Bureau.

820 L'ÉCHO. Papeete. December 1904-? Monthly in French.

821 L'ÉCHO DE TAHITI. Papeete. March 1921-July 1922. Monthly, then biweekly in French.

822 L'ÉCHO DE TAHITI. Papeete. 1951-1952? Weekly in French.

823 ÉCHO DU LAGON; BULLETIN DE L'ASSOCIATION DE LA POLYNESIE FRANÇAISE. Paris. January 1975-. Quarterly.

824 ECHOS DE TAHITI. Papeete. 1962-? In French and English. Tourist orientation.

825 ÉCHOS DE POLYNÉSIE. Papeete. August 1964-. Weekly in French. Superseded La Voix de Papeete (January 1964), which was issued three times.

826 ECHOES OF POLYNESIA (then TAHITI, ECHOES OF POLYNESIA). Papeete. August 1964-. Monthly in English. Tourist orientation.

827 L'ÉQUITÉ. Papeete. April-September 1919. Succeeded Le Libéral (March 1906-April/May 1918). Monthly in French.

828 LE FEl. Papeete. August 1919-April 1921. Bimonthly? in French.

829 TE FETIA ARATAI . . . Tahiti. 1847?-1848. Monthly in Tahitian. 
830 LE GUEPES. Papeete. March 1899-April 1902. Generally monthly, frequency varied. Edited and published in French by Paul Gauguin.

831 ICI TAHITI. Papeete. June 1964-? Weekly in French. Distributed weekly with Journal de Tahiti.

A publication listing radio programs, cinema, etc.

832 L'INDÉPENDANT. Papeete. 1899-1909? Monthly, then irregular in French.

833 LE JOURNAL DE PAPEETE. Papeete. November 1917-August 1918. Irregular in French. Acted as successor to Le Tahitien.

834 LE JOURNAL DE TAHITI. Papeete. March 1, 1963 —. Published daily except Sunday in French.

835 JOURNAL OFFICIEL DE LA POLYNÉSIE FRANÇAISE. Papeete. 1852 ? - Official gazette published first weekly (-August 1913), then biweekly. Title varied: Messager de Tahiti (September 1852-December 1883). In French with some Tahitian.

Includes some general news with the official news.

836 LE LIBÉRAL. See L'Équité.

837 TE MATA-ARA. Papeete. September-November 1957. Bimonthly in French.

838 TE MAU OPUARAA . . TE MAU FAAOTIRAA . . Papeete. November 1958-? Weekly in Tahitian.

839 MESSAGER DE TAHITI. See Journal Officiel de la Polynésie Française.

840 LE MESSAGER DE TAHITI. TE VEA NO TAHITI. Papeete. May 1884December 1889. Irregular in French.

841 LE MONDE POUR TOUS. Papeete. 1900? Edited and published by Paul Gauguin.

842 LES NOUVELLES. Papeete. April 1957 - Daily except Sunday in French, some Tahitian articles.

843 NOUVELLES TAHITIENNES. Papeete. February to August/September 1954. Monthly in French.

844 NOUVELLES TAHITIENNES. Papeete. 195?-1965. Frequency not determined. French language publication published by Information Service.

Feature articles directed at tourism.

845 L'OCÉANIE FRANÇAISE. Papeete. May 1844-July 1845. Weekly in French.

846 L'OCÉANIE FRANÇAISE. Papeete. January 1883-1903? Weekly in French. (-December 1887); then irregular in French. Predecessor was Le Petit Tahitien (October-December 1882), weekly in French. 
847 L'OCÉANIE FRANÇAISE: BULLETIN MENSUEL DU COMITÉ DE L'OCÉANIE FRANÇAISE. Paris. 1911-1914. 1916-1940?

Information on French possessions in Pacific.

848 LE PETIT TAHITIEN. See L'Océanie Française.

849 LES PETITE ANNONCES. Papeete. August 1952-May 1957. Weekly in French.

850 LES PETITES AFFICHES DE TAHITI. Papeete. February-December 1888. Weekly in French.

851 POLYNÉSIE FRANÇAISE. Papeete. 1962. In French and Tahitian. Frequency undetermined.

852 LA PRESSE DE TAHITI. TAMARII TAHITI. Papeete. February-July 1964. Weekly in French. Superseded Tamarii Tahiti, published in Bas Thorenc, A.M., then Papeete (September/October 1952-February 1964), issued three times a month, then bimonthly in French.

853 RAMEPA API. Raiatéa. September 1899-1912? Monthly in Tahitian.

Religious periodical, some general news.

854 REEF. Papeete. July/August 1966-July/August? 1967. Bimonthly.

Feature articles on Tahiti.

855 TE REPOSITORI. Moorea. 1828. In Tahitian.

Missionary publication; earliest publication in Tahiti.

856 LE RÉVEIL. TE ARA RAA. Papeete. October 1932-March 1933. Bimonthly in French.

857 SERVIR. See Vérités.

858 LE SOURIRE. Papeete. August 1899-April 1900. Weekly? in French edited by Paul Gauguin.

859 SI TOGI. Tahiti. 1943-1944? Chinese weekly.

860 TAMARII TAHITI. See La Presse de Tahiti. Tamarii Tahiti.

861 TAHITI BULLETIN. Papeete. March 2, 1967- Published five times per week in English and French.

862 TAHITI, ECHOES OF POLYNESIA. See Echoes of Polynesia.

863 TAHITI, LES NOUVEAUX OBJECTIFS. Papeete. January 1971-. Published monthly in French by Chambre de Commerce et d'Industrie; superseded Bulletin (1953-70), a monthly.

864 TAHITI MAGAZINE. Papeete. May 1960—. Monthly in French, emphasizing tourism.

865 TAHITI NEWS AND GENERAL ADVERTISER. Papeete. April 1891-? Biweekly in English. 
866 TAHITI TOURIST GUIDE. Papeete. March 1924-November 1929. Monthly in English.

867 TAHITI TOURIST GUIDE. BULLETIN OFFICIEL DU SYNDICAT D'INITIATIVE DE LA COLONIE DE TAHITI. Papeete. September 1931-August 1937. Monthly; then bimonthly in French and English.

868 LE TAHITIEN. Papeete. January-November 1894; January-April ? 1896. Biweekly? in French.

869 LE TAHITIEN. Papeete. October 1916-October 1917. Daily for ten months in French. Probable successor was Le Journal de Papeete.

870 TAHITI-FRANCE. Paris. April-September/October 1932. Monthly in French.

871 TEA VEA O TE HAU NO TAHITI. Papeete. June 1891-? Bimonthly in Tahitian.

872 TE TIARAMA NO TE MAU FENUA TAHITI. Paofai. January 1844- October 1845. First monthly; then irregularly in Tahitian. In Rare Collection, University of Hawaii.

873 TOREA. Papeete. May 1937-October 1939. Monthly in Tahitian.

874 LA TRIBUNE DE TAHITI. Papeete, then San Francisco. January 1912August 1915? In French. Frequency not determined.

875 LA TRIBUNE TAHITIENNE. Papeete. August 1960-November 1961. Weekly in French.

876 UNION. Papeete. July 1956-September 1958. Monthly in French.

877 L'UNION TAHITIENNE. Papeete. February 1959-1961? Bimonthly in French.

878 TE VEA MAOHI. Papeete. January 1930-1947? Monthly. Articles in Tahitian, Tuamotuan, Marquesan, Mangarevan. On microfilm, Pacific Manuscripts Bureau.

879 TE VEA NO TAHITI. Papeete. October 1850-January 1859. Weekly? in Tahitian. Microfilm copy at University of Hawaii.

880 TO TATOU AVEIA. Papeete. November 1949-December 1956. Irregular in French. Superseded by La Voix de Tahiti (January 1957-September 1958), monthly in French and Tahitian; To Tatou Aveia (December 1958-February 1959?), irregular in French.

881 VÉRITÉS. Papeete. November 1947-January 1948. Bimonthly in French. Superseded Servir (July-October 1947), weekly? in French.

882 LA VOIX DE PAPEETE. See Échos de Polynésie.

883 LA VOIX DE TAHITI. See To Tatou Aveia.

884 LE VRAI. Papeete. 1902-1908. Irregular in French. 


\section{CINEMA}

885 “"More Tahiti on Celluloid," PIM, 24, no. 5 (December 1953): 123.

Reviews Tahitian film, "Tanga Tika," and the director Dwight Long.

886 “'Big Tahiti Film-Shoot 'Next Year',' PIM, 27, no. 1 (August 1956): 59.

Reports shooting of "Typee" postponed but props being secured.

887 “To Be Filmed in Tahiti," PIM, 28, no. 2 (September 1957): 150.

Reports "The Stowaway" will be filmed in Tahiti soon.

888 “Marlon Turns the Heads in Tahiti,” PIM, 31, no. 2 (September 1960): 125.

Reports actor Marlon Brando looking for leading lady for film about mutiny on the HMS Bounty.

889 “'Some More Bounty for Tahiti," PIM, 31, no. 5 (December 1960): 57.

Reports MGM actors in Tahiti and local activities that are in preparation for filming "Mutiny on Bounty."

890 Sawyer, Beryl. “New 'Bounty' Brings Film-Makers to Eager Tahiti,” PIM, 31, no. 6 (January 1961): 27.

Reports filming activities, including use of 3,000 Tahitian "extras" and 900 outrigger canoes.

891 1961): 55-59.

"Life on a Desert Isle-Paris Style," PIM, 31, no. 7 (February

Reports Tarita Teriitaia from Bora Bora chosen to portray female lead in film "Mutiny on Bounty."

892 “Censuré," La Dépêche de Tahiti, November 2, 1976, 4: 5.

La Dépêche editors announce discontinuation of some film advertisements after film advertisers take exception to religious censure of films.

\section{EDUCATION AND TRAINING OF COMMUNICATORS}

893 “'Tonga, Western Samoa, Tahiti Get Look at Video Tape," PICN, 4, no. 2 (December 1973): 3 .

Describes traveling videotape training session by Christian Education and Communications Program.

\section{FREEDOM OF THE PRESS/BROADCASTING}

894 “'Red Propaganda Banned in Tahiti,” PIM, 3, no. 8 (March 1933): 12.

Reports publication of a presidential decree regulating the introduction of foreign publications into French Polynesia and limiting publications in languages other than French.

895 “War News On Remote Islands,” PIM, 10, no. 4 (November 1939): 21.

Compares availability of war news in 1914 and 1939.

\section{THE PRESS}

896 “Conservation of Old Tahiti," PIM, 9, no. 1 (August 1938): 42.

Brief mention of expansion of Tahitian language edition of the official government journal.

897 Snow, Edward C. "Fame-and Tahiti: From Captain Cook to Doug Fairbanks," PIM, 14, no. 5 (December 1943): 27.

Notes low production of printed matter in Tahiti. 
898 “Newspaper for French Oceania,” PIM, 24, no. 9 (April 1954): 112.

Notes appearance of mimeographed newspaper, La Concierge.

899 “Ins and Outs of Newspaper Publication," PIM, 25, no. 6 (January 1955): 134.

Reports decision of Territorial Assembly to stop publishing the government periodical, Nouvelles Tahitiennes, citing financial losses.

900 Drilhon, Freddy, "Gauguin Was Tahiti's First Journalist," $P I M, 30$, no. 11 (June 1960): 53, 55.

Describes Paul Gauguin's efforts to edit, publish, and print three different newspapers (Les Guêpes, Le Sourire, Le Monde pour Tous) in Tahiti at the turn of the century.

901 “100 Ans de Journalisme: Que se Passait-il en Europe et Surtout en France?” Corail, 51 (January 17, 1963): 14-19.

Gives historical information on newspapers in French colonies.

902 “In a Nutshell," PIM, 35, no. 5 (May 1964): 116.

Reports Le Journal de Tahiti, Tahitian daily, has been publishing for one year.

903 “'Tropicalities,” PIM, 35, no. 9 (September 1964): 17.

Article reviewed current newspapers in Tahiti: Ici Tahiti, Échos de Polynésie, La Presse, and Le Canard Tahitienne, all weeklies; Tahiti Magazine, issued quarterly.

904 “Tahiti Newspaper Confusion,” PIM, 35, no. 10 (October 1964): 17.

Corrects error in September issue, noting Philippe Mazellier's ownership of La Dépêche, Alfred Poroi's interest in Échos de Polynésie, and cessation of La Presse.

905 Danielsson, Bengt, and Patrick O'Reilly. “Gauguin Journaliste à Tahiti et ses Articles des Guêpes,"' Journal de la Société des Océanistes, 21 (December 1965): 1-53.

An account of Paul Gauguin's journalistic activities in Tahiti, with a collection of his articles that appeared in Les Guêpes from 1899 to 1901.

906 Newbury, Colin W. “La Représentation Politique en Polynésie Française, 1880-1903: Étude d'un Cas d'Assimilation,' Journal de la Société des Océanistes, 23 (December 1967): 2-27.

Historical account of government of French Polynesia; discusses establishment and usefulness of $L e$ Messager de Tahiti in centralizing colonial government.

907 Langdon, Robert. "Tahiti's David May Yet Sway Struggle with Goliath," PIM, 40, no. 1 (January 1969): 62-71.

Reviews history of $\mathrm{Te} \mathrm{Ara}$ ' $\mathrm{tai}$, a political journal.

908 Thompson, Virginia, and Richard Adloff. The French Pacific Islands: French Polynesia and New Caledonia. Berkeley: University of California Press, 1971. 539 pp.

Includes a chapter on communication media in the twentieth century.

909 Jacoby, Alfred. “Dream Job: American Editor has Own Tahiti Newspaper," $S-B$, March 29, 1971, C-3: 1 .

Reviews James Boyack's career as editor of English-language Tahiti Bulletin. 
910 Anglade, Michel. "Organization and Problems of a Press Enterprise in Tahiti."' Paper prepared for South Pacific Editors Conference, Suva, Fiji, July 30August 5, 1972. Honolulu: East-West Center, Communication Institute, 1972. 6 pp. (mimeo).

Discusses organization and problems of newspapers in Tahiti, using La Dépêche as an example; discusses recruitment, training, and supplies.

911 Boyack, James. "The Press in Tahiti." Paper prepared for South Pacific Editors Conference, Suva, Fiji, July 30-August 5, 1972. Honolulu: East-West Center, Communication Institute, 1972. 7 pp. (mimeo).

Discusses insular nature of news printed in Tahiti's newspapers and other characteristics of the Tahitian press.

912 Anglade, Michel. "La Dépêche dans Nouveaux Locaux," PICN, 5, no. 4 (December 1975): 6 .

Announces that La Dépêche de Tahiti, French-language newspaper with circulation of 5,500, moved into new facilities.

913 Wright, Glen. "A Shout of Joy and a Cry of Pain: The Press in the South Pacific,"'Index on Censorship, 5, no. 4 (Winter 1976): 49-53.

Article on development of the press in the Pacific includes information on early press in Tahiti: first periodical printed in French Polynesia was Te Repository, started in 1826; first French-language newspaper, L'Océanie Française, published from 1844-45.

\section{PRINTING}

914 Ellis, William. The History of the London Missionary Society, vol. 1. London: John Snow, 1844. 579 pp.

Includes accounts of early printing activities of missions to Tahiti.

915 Horne, C. Silvester. The Story of the L.M.S., new ed. London: London Missionary Society, 1904. $460 \mathrm{pp}$.

Chapter 2 includes an account of early mission printing activities; an earlier edition was published in 1894.

916 Harding, George L. “Tahitian Imprints, 1817-1833," Papers of the Bibliographical Society of America, 35, no. 1 (1941): 48-57.

History of early printing by missionaries in the Society Islands.

917 and Bjarne Kroepelien. The Tahitian Imprints of the London Missionary Society, 1810-1834. Oslo: La Coquille Qui Chante, 1950.96 pp.

Limited edition of a preliminary bibliography with an introductory chapter on the history of the printers and presses of the Society Islands.

\section{RADIO BROADCASTING}

918 “'Radio Boom Likely in French Oceania," PIM, 2, no. 6 (January 1932): 37.

Reports revision of regulations on radio receivers and transmitters.

919 “Tahiti Radio Club," PIM, 6, no. 1 (August 1935): 42.

Short item on broadcasts by radio club in Papeete. 
920 “'Tahiti Radio Club Efforts to Attract Tourists," PIM, 6, no. 12 (July 1936): 55.

Describes activities of Radio Club Océanien in Papeete.

921 “'New Equipment for Tahiti Broadcasting," PIM, 7, no. 3 (October 1936): 34.

Reports installation of a more powerful transmitter by Tahiti Radio Club.

922 “Tahiti: Polynesian Amateurs Air Home Talent Twice Weekly," Newsweek, 8, no. 25 (December 19, 1936): 35-36.

Sketch of radio broadcasting in Tahiti, with emphasis on program content.

923 “'Radio for Tahitian Festivities,” PIM, 7, no. 8 (March 1937): 52.

Notes first broadcast in Papeete of a description of a horse race.

924 “'Tahiti's Lord Haw-Haw and the Answer to Him," PIM, 13, no. 6 (January 1943): 44.

Discusses Japanese use of Tahitian-language radio propaganda broadcasts.

925 “Papeete Broadcasts," PIM, 24, no. 10 (May 1954): 137.

Gives schedule and frequencies of shortwave broadcasts from Papeete.

926 “'Radio Tahiti,” PIM, 26, no. 12 (July 1956): 23.

Notes improvements in broadcasts from Radio Tahiti.

927 “'Broadcasting in the Pacific,”' $S P B, 6$, no. 4 (October 1956): 41-45, 56.

Describes broadcasting facilities in French Polynesia and other island areas.

\section{SATELLITE COMMUNICATION}

See also Pacific Islands General

928 Anglade, Michel, and Jim Boyack. "Conférence des Directeurs de Journaux du Pacifique Sud: Le Projet 'PEACESAT' et Ses Applications," La Dépêche de Tahiti, August 11, 1972, p. 6.

Reviews PEACESAT Project.

\section{TELEVISION}

929 “New Caledonia, Tahiti to Have TV, Too," PIM, 35, no. 11 (November 1964): 63-64.

Reports plans of French government to install television stations in Tahiti and New Caledonia.

930 “'Tahiti Has TV, Too,” PIM, 36, no. 11 (November 1965): 40.

Notes first television transmission in Tahiti.

931 “'It's All ‘Go' For French Pacific TV,” PIM, 36, no. 12 (December 1965): 8.

Discusses plans for Tele-Noumea and Tele-Tahiti. 


\section{Gilbert Islands}

(The Ellice Islands separated from the Gilbert Islands in October 1975 and became Tuvalu, with full separation occurring in January 1976. Information concerning both island groups is listed under each name.)

\section{NEWSPAPERS, PERIODICALS}

932 ATOLL PIONEER. Bairiki, Tarawa. September 7, 1972-. Weekly in English and Gilbertese. Published by Information Division, Gilbert Islands. Incorporated Tero and Valo in 1974. Superseded Colony Information Notes (19631972), a weekly in English; News from The Gilbert and Ellice Islands Colony (19551962), a monthly in English. Frequency varied in earlier years.

933 BANAN TUNGAVALU. JOURNAL OF THE TUNGAVALU SOCIETY. Tarawa. 1974 - Monthly in Gilbertese and English.

Journal provides general news.

\section{COLONY INFORMATION NOTES. See Atoll Pioneer.}

935 GILBERT AND ELLICE ISLANDS COLONY GAZETTE. See Gilbert Islands Gazette.

936 GILBERT ISLANDS GAZETTE. Tarawa. October 1975-. Official gazette published monthly with occasional legal supplements. Superseded Gilbert and Ellice Islands Colony Gazette (1968-1975). Previous legal gazette was Western Pacific High Commission Gazette (1914-1967), which included ordinances, administrative changes, etc., for the Gilbert and Ellice Islands, Fiji, British Solomon Islands and New Hebrides, while each island group was part of Great Britain's Pacific Colonies.

937 NEWS FROM THE GILBERT AND ELLICE ISLANDS COLONY. See Atoll Pioneer.

938 SAIL HO. See Tero.

939 TERO. First published in Fiji by the Fiji Information Office with the title Sail $H o$, then in Tarawa with the title Tero, by the Gilbert and Ellice Islands Colony Information Department. 1945-May 1974. Monthly in Gilbertese. Incorporated in Atoll Pioneer in 1974. 
940 VALO. Tarawa. September 16, 1965-1974. Published biweekly in Ellice by the Gilbert and Ellice Islands Information Division. Incorporated in Atoll Pioneer in 1974.

941 WESTERN PACIFIC HIGH COMMISSION GAZETTE. See Gilbert Islands Gazette.

\section{GOVERNMENT AND INTERNATIONAL AGENCY REPORTS}

942 Kittermaster, A.M. A "Report on Information and Broadcasting Services in the Gilbert and Ellice Islands." London. Commissioned by the Ministry of Overseas Development. July 1970. 69 pp.

Describes and assesses broadcasting services, departmental structure and staff programming, information services, community development and communication services; role of information and broadcasting. Appendices.

\section{CINEMA}

943 “Censorship: Pros and Cons,” PICN, 5, no. 4 (December 1975): 5.

Describes opinions of persons writing to Atoll Pioneer and of Guam newspaper editor regarding film censorship.

\section{EDUCATION AND TRAINING OF COMMUNICATORS}

944 “'NZBC Officer for Gilbert and Ellice Islands,"' $A B U$, no. 82 (March 1972): 50.

Announces that Howard Gough has been seconded to UNESCO as broadcasting training expert to plan and conduct radio training courses in the Gilbert and Ellice Islands.

945 Watts, Frank. "ABC Activities in the Training of Overseas Educational Broadcasters," Educational Broadcasting International, 6, no. 3 (September 1973): 145-47.

Describes training programs conducted by Australian Broadcasting Commission, 1967-1972; trainees from Gilbert and Ellice Islands and other Pacific areas.

\section{GOVERNMENT INFORMATION ACTIVITIES}

946 “'Sail Ho," PIM, 15, no. 8 (March 1945): 24.

Notes publication by the Fiji Information Office of a news magazine titled Sail Ho for the Gilbert and Ellice Islands.

947 “GEIC Produces Local News Bulletin,” PIM, 25, no. 9 (April 1955): 87.

Notes appearance of monthly news bulletin published by Gilbert and Ellice Colony government in English; joins two news sheets being published in local languages.

948 “Newsletters Appear for Executive Officers," PICN, 5, no. 1 (February 1975): 9.

First edition of Teitei, a newsletter for Island Executive Officers, issued by the district office at Tabiteuea North, in the Gilbert and Ellice Islands. 


\section{THE PRESS}

949 “Newspaper Changes Name," PIM, 43, no. 10 (October 1972): 16.

Reports Colony Information Notes name changed to A toll Pioneer recently; photograph of newspaper staff.

\section{RADIO BROADCASTING}

950 “'Broadcast Station for Gilberts," PIM, 24, no. 12 (July 1954): 59.

Reports limited shortwave broadcasting from Gilbert Islands station.

951 “Pacific Broadcast Changes,” PIM, 25, no. 5 (December 1954): 143.

Gilbert Islands officials expect regular broadcasting in 1955.

952 “GEIC Broadcasting Service Progresses," PIM, 26, no. 2 (September 1955): 24.

Announces new building completed for Radio Tarawa (VTW); station broadcasts about one hour per day.

953 "Broadcasting in the Pacific," SPB, 6, no. 4 (October 1956): 41-45, 56.

Describes broadcasting facilities in various Pacific Island areas.

954 “New Broadcast Station for Tarawa,” PIM, 29, no. 7 (February 1959): 147.

Notes plans for improved broadcast service.

955 “New Broadcasts From Fiji and Tarawa," PIM, 30, no. 10 (May 1960): 127. Improved transmitter planned at Tarawa.

956 MacDonald, Barrie. "Local Government in the Gilbert and Ellice Islands, 1892-1969," Journal of Administration Overseas, 10, no. 4 (October 1971): 280-93; 11, no. 1 (January 1972): 11-27.

Part two contains passing reference to unsatisfactory use of broadcasting and written materials in explaining 1966 local government ordinance.

957 "Gilberts and Tuvalu Strengthen Radio Signal," PICN, 5, no. 4 (December 1975): 9.

Installation of new studio center at Funafuti improves broadcast reception.

958 “GEIBS becomes GIBS,” $A B U$, no. 119 (January 1976): 6.

Major changes for the Gilbert and Ellice Islands Broadcasting Service in January 1976 due to independence of Ellice Islands. New radio station for Tuvalu will be Tuvalu Broadcasting and Information Service. Staff changes announced. Article reviewed by PICN, 6, no. 2 (June 1976): 7.

\section{SATELLITE COMMUNICATION}

See also Pacific Islands General

959 “'Links Into Satellite,” PICN, 5, no. 1 (February 1975): 9.

Announces beginning of operation of Tarawa satellite communication terminal. 


\section{Guam}

\section{INDEXES, GUIDES, REFERENCE WORKS}

960 Index to the Guam Recorder. Agana: Guam Public Library, n.d.

An index to the Guam Recorder, vol. 1-18, March 1924 to November 1941.

NEWSPAPERS, PERIODICALS

961 CONSTRUCTIONNAIRE. Agana. 1946-February 29, 1956. Weekly. Published by Brown-Pacific-Maxon in English.

962 DATELINE. See Pacific Dateline.

963 GLIMPSES. Agana. 1960-. Volumes 1-14, annual; volume 15-, quarterly (not published 1961). Titled Glimpses of Guam through 1976. First published by Navy Relief Carnival; from 1974 published by Glimpses of Guam Company, Ltd.

964 GLIMPSES OF GUAM. See Glimpses.

965 GUAM ADVERTISER. Agana. -1912-. Publication details unknown.

966 GUAM BULLETIN. Agana. -1931-. Publication details unknown.

967 GUAM DAILY MIRROR. Agana. July 1961 only. Micronesian Area Research Center has copies.

968 GUAM DAILY NEWS. See Pacific Daily News.

969 GUAM ECHO. Washington, D.C. February 1947-March 1950. Published by Institute of Ethnic Affairs. Nieves M. Flores Memorial Library has issues of May 31, 1948-May 15, 1950.

Contains general news.

970 GUAM EXAMINER. Agana. 1951?-1952? Nieves M. Flores Memorial Library has issues of February 1951-December 1952. 
971 GUAM NEWS. See Pacific Daily News.

972 GUAM NEWS LETTER. 1908-1922. Published monthly by Naval Government of Guam. In English and Spanish from 1909 to August 1911. Biweekly for short period in last year of publication. Microfilm copies (incomplete) of issues of October 1910 to 1922 available at University of Hawaii, New York Public Library. Index prepared by Nieves M. Flores Memorial Library, Guam. Papers which acted as successors are Information Bulletin and Guam Recorder.

973 GUAM PROFILE. Agana. 1963. Publication details unknown. Nieves M. Flores Memorial Library has 1963 issues.

974 GUAM RECORDER. Agana. 1924-1941. Published monthly as a private enterprise from 1924 to 1933; thereafter by the U.S. Navy. Index prepared by Nieves M. Flores Memorial Library, Guam. A predecessor paper was Information Bulletin (June 15, 1922-February 22, 1924), issued as a single-faced, loose-leafed bulletin; frequency undetermined.

975 GUAM RECORDER, n.s. Agana. 1971—. Published irregularly (three or four times yearly) by the Micronesian Area Research Center, University of Guam.

976 GUAM TIMES WEEKLY. Agana. February 1964-1966. Weekly in English.

977 GUAM VILLAGER. Agana. August-September 1961. Micronesian Area Research Center has copies.

978 GUAM WEEKLY BULLETIN. Agana. February 7-May 8, 1932. In English and Chamorro.

979 GUAM WEEKLY EXAMINER. Agana. February-March 1951. Micronesian Area Research Center has copies.

980 INFORMATION BULLETIN. See Guam Recorder.

981 ISLANDER. See Pacific Daily News.

982 MORNING STAR. Agana. October 1969-197? Daily. Micronesian Area Research Center has copies.

983 PACIFIC DAILY NEWS. Agana. February 2, 1970-. Daily and Sunday in English. Sunday edition titled Pacific Sunday News, with supplement titled Islander (1975 - ). Paper titled previously Guam Daily News (June 16, 1950-January 31, 1970) with Sunday edition titled Territorial Sun (December 30, 1951-January 25, 1970). Earliest title of paper was Guam News (1948-June 15, 1950). Microfilm copies available at University of Hawaii.

984 PACIFIC DATELINE. Agana. July 6, 1970-November 30, 1975. Daily except Saturday in English. Also known as Dateline.

985 PACIFIC JOURNAL. Agana. July 17, 1966-196? Daily.

986 PACIFIC PROFILE. November 1963-April 1966. Monthly.

987 PACIFIC SUNDAY NEWS. See Pacific Daily News. 
988 PACIFIC VOICE. Agana. January 5, 1947—. Weekly. Titled Umatuna Si Yuus (January 5, 1947-April 22, 1973); Pacific Voice from April 29, 1973.

989 TERRITORIAL SUN. See Pacific Daily News.

990 THIS MONTH IN GUAM. Agana. June 1972 — . Monthly.

991 TV \& ENTERTAINMENT WEEK. Agana. September 16, 1973-September? 1974. Weekly.

992 TV GUAM. Agana. 1973 — Weekly publication of Holmes Management Corporation.

993 UMATUNA SI YUUS. See Pacific Voice.

\section{CINEMA}

994 "The Service Cinematograph," Guam News Letter, 5, no. 9 (September 1913): 2.

Describes first film service to be open to public.

995 “Moving Picture Photographer Coming to Guam": Guam News Letter, 12, no. 2 (November 1920): 2.

Announces first film to be made in Guam.

996 "Local Motion Picture House to Show New Films," Guam News Letter, 13, no. 2 (October 1921): 8.

Announces first-run films from U.S.A. to be shown starting in October or November.

997 "Local Movie House Starts New Film Service," Guam News Letter, 13, no. 4 (December 15, 1921): 9.

First-run films now being shown in Guam.

998 "Censorship: Pros and Cons," PICN, 5, no. 4 (December 1975): 5.

Relates opinions of editor of Pacific Dateline on film censorship bill for Guam.

\section{EDUCATION AND TRAINING OF COMMUNICATORS}

999 Guam. University. Language Arts Division. "A Proposal for Interdisciplinary Study of Communication." Submitted to the Gannett Foundation. July 15, 1974. 32 pp.

Discusses journalism training needs in Guam and Micronesia and makes detailed proposal for such a program at the University of Guam.

1000 “Journalists Study Chamorro," PICN, 4, no. 4 (September 1974): 10.

Pacific Daily News and Pacific Dateline sponsor training in Chamorro language for reporters working in Guam; need for language capability highlighted by political campaign.

1001 "University of Guam Seeks to Establish Communication Program," PICN, 4, no. 4 (September 1974): 10.

Details of University of Guam proposal, including program, personnel, and funding. 


\section{EDUCATIONAL MEDIA}

1002 National Education Association. Division of Educational Technology. "The Guam Multi-Media Feasibility Study." A report to the Government of Guam, Department of Education, College of Guam, private and parochial schools of Guam, Government and people of Guam, and U.S. Office of Education. November 1967. $235 \mathrm{pp}$.

A feasibility study of the establishment and operation of a learning resources center with multi-media services for the school systems of Guam; includes recommendations on educational radio and television broadcasting.

1003 Smith, Dan. "Public Television," Glimpses of Guam, 12 (1972-73): 22-23.

Reviews programming of KGTF, which started operations in 1970 as a public television station.

1004 "KGTF-Aiming at the Island's Most Precious Possession," $G R$

n.s., 3, no. 1 (January-March 1973): 20.

Short sketch of aims of Guam public television station written by the station's general manager.

1005 “Guam TV Station in Financial Block," PICN, 5, no. 4 (December 1975): 8.

Guam's only public television station having difficulty raising percentage of its budget required by law.

\section{FREEDOM OF THE PRESS/BROADCASTING}

1006 “'Admiral Threatens Press on Guam: 'I am The Law',' S-B, August 26, 1952, $1: 4$.

Admiral Ernest W. Litch accused of threatening to suppress two island newspapers for mentioning wife's name in gossip column.

1007 "Navy Curbs Press Coverage of New Guam Governor," $A D V$, April 21, 1953, 2: 7.

Photographers barred from greeting plane on Guam Naval Air Station.

1008 “Dispute Dies as Governor Reaches Guam,” S-B, April 22, 1953, 15: 1.

Guam Daily News reporters allowed on air station for arrival of officials; newspaper sources said that their photographers had been banned from base, although Rear Admiral Ernest W. Litch denied this.

\section{THE PRESS}

\section{General}

1009 “Guam Newspapers,” GR, 8, no. 12 (March 1932): 475.

History of publications in Guam during United States control.

1010 “Volume X-No. 1." GR, 10, no. 1 (April 1933): 2.

Brief summary of newspaper history in Guam.

1011 Stevens, Russell L. Guam, U.S.A.: Birth of a Territory, 2d. rev. ed. Honolulu: Tongg Publishing Co., 1956. 188 pp.

Contains brief account of status of newspaper publishing. 
1012 Kahn, E. J., Jr. A Reporter in Micronesia, New York: W. W. Norton and Co., 1966. 313 pp.

Journalistic account of conditions in the U.S. Trust Territory of the Pacific Islands and Guam; includes description of the state of publishing, enumerating publications and referring occasionally to their editorial positions.

1013 “'Increased Pacific Newspaper Activity," PICN, 1, no. 2 (September 1970): $1-2$.

Honolulu Star-Bulletin expanding service into Guam, possibly Samoa; discusses future of newspapers in the Pacific.

1014 "Business Magazine Planned for Guam," Pacific Daily News, May 27, 1971,

2: 3 .

Guam Publications plans new monthly magazine to specialize in area developments in trade and business.

1015 "Guam Papers Seek Marianas Business," Pacific Daily News, March 31, 1973, 25: 2.

Reports application by Guam Publications, publisher of Guam's two daily newspapers, to do business in the Trust Territory.

\section{Guam Advertiser}

1016 McIntosh, K. C. "What Will You Do?" Guam News Letter, 3, no. 7 (January 1912): 1-3.

Brief mention of "our young and business-like little contemporary" paper, the Guam Advertiser, in news story.

\section{Guam Bulletin}

1017 "The Guam Bulletin Makes Its Bow," GR, 8, no. 11 (February 1931): 456.

Notes appearance of Guam Bulletin.

\section{Guam Daily News}

1018 "Guam News at Three Dominates West Pacific," Editor \& Publisher, 81, no. 53 (December 25, 1948): 22.

Account of third anniversary of Guam News; paper's history and personnel discussed.

1019 "Guam Paper for Sale," NYT, December 16, 1949, 2: 4.

Navy-owned Guam News offered for sale.

1020 “Guam Resident to Take Over Navy Paper,"' $S$ - $B$, May 11, 1950, 7: 5.

Navy turning over newspaper to private ownership; Joseph Flores won Navy bid for purchasing building and equipment, also named editor.

1021 “Navy Picks Guam Publisher,” NYT, May 11, 1950, 11: 5.

Navy names Joseph Flores of Agana to publish newspaper.

1022 Kahn, E. J., Jr. "Letters from Guam," New Yorker, 40, no. 52 (February 13, 1965): 39-40.

Includes Guam Daily News activities.

1023 “Bulletin Negotiates for Guam News," $S$-B, January 14, 1970, A-1: 3.

Honolulu group headed by the Honolulu Star-Bulletin, negotiating to buy Guam News. 
1024 Guam News Purchased," $A D V$, January 16, 1970, B-13: 4.

Announcement of agreement to buy the Guam News by group headed by Honolulu Star-Bulletin.

\section{Guam News Letter}

1025 "Departure of the Editor of the News Letter," Guam News Letter, 5, no. 2 (August 1913): 6-7.

Editor of newspaper for $2 \frac{1}{2}$ years, Paymaster K. C. McIntosh, has left island.

1026 “Changes in Editorship,"' Guam News Letter, 5, no. 3 (September 1913): 8-9.

Reports staff changes.

1027 “A Popular Newspaper," Guam News Letter, 6, no. 2 (August 1914): 6.

Letter attests to usefulness of Guam Daily News.

1028 “News Letter to be Placed on Sale," Guam News Letter, 7, no. 1 (July 1915): 13.

Publication not distributed freely after July 1915 due to increasing costs for production and popularity of paper; additional 200 per month will be printed.

1029 "Changes of Management," Guam News Letter, 8, no. 6 (1916): 10.

Reports staff changes.

1030 "'Changes of Management,"' Guam News Letter, 8, no. 7 (1917): 8.

Reports staff changes.

1031 "It's An Ill Wind That Doesn't Help A Newspaper," Guam News Letter, 8, no. 8 (February 1917): 30.

Interest in war news raised subscriptions for paper by 6 percent.

1032 “News Letter Growth,” Guam News Letter, 8, no. 11 (May 1917): 24.

April 1917 sales of paper reached nearly 1000.

1033 “Change of Management," Guam News Letter, 9, no. 3 (September 1917): 17.

Reports staff changes.

1034 “'New Press Arrives," Guam News Letter, 10, no. 9 (March 1919): 16.

Announcement of new printing press by Navy.

1035 “Navy Printing Office," Guam News Letter, 10, no. 12 (June 1919): 17.

Reports better facilities for Navy paper.

1036 "The Policy of the News Letter,' Guam News Letter, 12, no. 11 (June 1921): 10.

Describes how newspaper is put together and rules for inclusion of news in paper.

1037 “Advertising Matter Now Accepted in Guam News Letter," Guam News Letter, 12, no. 12 (July 1921): 12 .

Decision of Navy Department to allow advertising.

1038 “To Our Readers," Guam News Letter, 13, no. 2 (October 1921): 1.

Reports most of printing crew shipped out; newspaper might have to reduce its size. 
1039 "Editorial: A Word of Explanation," Guam News Letter, 13, no. 6 (February 15, 1922): 2.

Article explains that newspaper will revert to monthly publication due to cost of supplies. Newspaper is now being mimeographed rather than printed.

1040 “"Editorial," Guam News Letter, 13, no. 7 (March 31, 1922).

Paper announces this as last edition; Navy policy not to let newspaper use its facilities and difficulty of putting out paper by mimeographing caused decision.

\section{Guam Recorder}

1041 "The Guam Recorder: Its Policy, Purpose and Power," GR, 1, no. 1 (March 1924): 3.

1042 "A Service Magazine and Chronicle of Local Events," GR, 1, no. 2 (April 1924): 14.

1043 "New Departments of the Guam Recorder," $G R, 1$, no. 5 (August 1924): 2.

1044 "The Recorder One Year Old," GR 1, no. 11 (February 1925): 1.

1045 "Gob Stranded, Edits Newspaper; Guam Paper Organized by Former Machinist," GR, 1, no. 12 (March 1925): 1.

Reviews founding of publication, background of editor, progress in first year.

1046 "Resignation of the Recorder's First Editor," GR, 2, no. 9 (December 1925): 261.

Letter by departing editor, P. J. Searles; statement of policy.

1047 “Looking Forward," GR 3, no 12 (March 1925): 323.

Editorial review of Recorder's policy.

1048 “"What's Wrong?" GR, 4, no. 8 (November 1927): 193.

Statement of editorial policy and financial condition.

1049 “Four Years Young Last Month," GR, 5, no. 2 (May 1928): 38.

Anniversary review of editiorial policy.

1050 “'Our Sixth Anniversary,” GR, 6, no. 12 (March 1930): 225.

Annual statement of policy.

1051 “We Want News," GR, 6, no. 12 (March 1930): 225.

Moral, historical, and ethical reasons for publishing paper.

1052 "This Issue Marks Seventh Year of the Guam Recorder," $G R, 7$, no. 12 (March 1931): 234.

Short announcement.

1053 "Published for Guam Folks," GR, 8, no. 8 (November 1931): 396.

Reviews history and editorial policy.

1054 "Eight Years Old," GR, 9, no. 4 (July 1932): 2.

Short statement of policy on anniversary of publication. 
1055 "Ninth Milestone," $G R, 9$, no. 12 (March 1933): 202.

Anniversary editorial; comments on role of publication in finding and printing historical records.

1056 “Guam Recorder Sold," GR, 10, no. 7 (October 1933): 105a.

Reports sale to U.S. Navy.

1057 “" 'Recorder' Under New Management,”' $G R, 10$, no. 8 (November 1933): 123.

Announces transfer of Recorder to direct management of the Naval Government of Guam and status as official gazette.

1058 "Guam Recorder Popular," GR, 10, no. 10 (January 1934): 161.

1059 “'Over the Editorial Desk," GR, 11, no. 5 (August 1934): 92.

Ten-year review of editorial policy, progress, future development.

1060 “'Our New Editor,” GR, 11, no. 5 (August 1934): 79.

Biographical sketch of editor, L. N. Lindsley.

1061 "New Secretary and Office for the Guam Recorder," $G R, 12$, no. 3 (June 1935): 64 .

Short announcement,

1062 "Changes in the Staff of the Recorder," $G R, 12$, no. 5 (August 1935): 118.

1063 “'Ye Editor Departs," $G R, 13$, no. 1 (April 1936): 7, 44.

Tribute to departing editor, L. N. Linsley.

1064 “Typographically Speaking," $G R, 13$, no. 6 (September 1936): 1.

Discusses the printing, typesetting, and binding methods used by the Recorder.

1065 “The Recorder," GR, 13, no. 9 (December 1936): 1.

Statement of purpose and announcement of price reduction to increase readership. Reprinted in Guam Recorder, 15, no. 1 (April 1938): 5.

1066 “"The New Editor,"' GR, 14, no. 8 (November 1937):17.

Notice on change of editors.

1067 “Seventeenth Anniversary," $G R, 17$, no. 1 (April 1940): 6.

Sketchy history of Guam Recorder and its predecessors, Guam News Letter and Information Bulletin.

1068 “Adios," GR, 18, no. 2 (May 1941): 50.

Statement of departing editorial staff.

1069 Carano, Paul. "The Guam Recorder-A Brief History," $G R$, n.s., 1, no. 1 (October-December 1971): 3.

Sketches history of original Guam Recorder, March 1924-November 1941.

\section{Pacific Daily News/Pacific Dateline}

1070 "Chinn Ho's Group Buys Guam Paper," Editor \& Publisher, 103, no. 4 (January 24, 1970): 16.

Agreement in principle reached for purchase of Guam Daily News and its Sunday sister paper, The Territorial Sun, from Pacific Press, Inc., by Guam Publications, Inc., majority of stock in which owned by Honolulu Star-Bulletin. 
1071 “S-B Subsidiary Has Option to Purchase Samoa Paper' $S-B$, August 21, 1970, 2: 1 .

Guam Publications, Inc., enters into option agreement to purchase majority stock in The Samoan Times.

1072 “Gannett to Acquire Hawaii Newspapers," NYT, August 3, 1971, 25: 3.

Purchase of Pacific Daily News and Pacific Dateline along with acquisition of Honolulu Star-Bulletin.

1073 “'Gannett Completes Deal with Honolulu Company," NYT, November 2, 1971, 53: 2.

Acquisition by Gannett of Pacific Daily News and Pacific Dateline.

1074 Murphy, Joe. “Lone Japanese Soldier Had Whole Staff Hopping," Gannetteer, (March 1972): 22-23.

Describes Pacific Daily News/Pacific Dateline coverage of the emergence of a Japanese soldier after 28 years of hiding in the jungles of Guam.

1075 “'Guam Paper, Micronesia Congress in News Agreement," PICN, 4, no. 1 (August 1973): 5-6.

Particulars of news agreement between Congress of Micronesia and the Guam newspapers, Pacific Daily News and Pacific Dateline.

\section{PRINTING}

1076 “"Talofofo," GR, 1, no. 2 (March 1924): 11.

1077 “'Commercial Printing,” GR, 14, no. 11 (February 1938): 6.

Notes Guam Recorder is only privately owned printing establishment in Guam.

\section{RADIO BROADCASTING}

1078 “'Guam Governor's Annual Report. August 23, 1916." Guam News Letter, 8, no. 3 (September 1916).

Refers to appropriations for new medium power radio station and facilities; station to operate by April 1917.

1079 Clark, F. P. "The New Radio Tower," Guam News Letter, 12, no. 1 (August 1920): 9 .

Describes construction of 600 -foot radio tower built in 1919 to supplement the two 400 -foot towers presently in use.

1080 “'Radio Phone Used for Concert,"' Guam News Letter, 12, no. 11 (June 1921): 2.

San Francisco concert transmitted via radio to Honolulu, Alaska, and other points.

1081 “'Radio Guam,” GR, 2, no. 4 (June 1925): 119.

1082 “Federal Company to Equip Gigantic Radio Station," GR, 5, no. 7 (September 1928): 131 . 
1083 “'Robert Dollar Radio,"' GR, 6, no. 11 (February 1930): 211.

Reports proposal of Robert Dollar Company of San Francisco to build radio broadcast station on Guam.

1084 “"Commercial Radio for Guam," GR, 6, no. 12 (March 1930): 243.

Reports planned arrival of a representative of a commercial broadcasting station to seck site for construction.

1085 “Robert Dollar Commercial Radio," GR, 7, no. 1 (April 1930): 9.

1086 "Guam Radio is Licensed," $A D V$, August 27, 1953, 5: 4.

FCC issued conditional grant for radio station on Guam; a fulltime-operation on 610 kilocycles with 1000 watts.

1087 Stevens, Russell L. Guam, U.S.A.: Birth of a Territory, 2 d rev. ed. Honolulu: Tongg Publishing Co., 1956. $188 \mathrm{pp}$.

Contains brief account of status of newspaper publishing and radio broadcasting.

1088 “'Broadcasting in the Pacific,' SPB, 6, no. 4 (October 1956): 41-45, 56.

Describes broadcasting facilities in Guam and other Pacific Island areas.

1089 “Radio Operation Slated on Guam," $A D V$, July 9, 1960, B-1: 13.

One-kilowatt radio station planned for Guam by three Honolulu businessmen in partnership with Joseph Flores, Guam's Governor and a newspaper publisher.

1090 "They Staked Their Lives So They Can Hear the News," Pacific Profile, 3, no. 6 (July 1965): 14-16.

Recounts experiences of three Guam residents who kept a radio receiver in contravention of Japanese occupation rules during World War II.

1091 Caton, Nancy. “KUAM," Pacific Profile, 3, no. 9 (November 1965): 33-36.

Feature article on KUAM radio and television; emphasis on programming.

1092 "AFRN at NCS-Six Transmitters to Reach All the Sailors," $G R$, n.s., 3, no. 1 (January-March 1973): 39.

Describes facilities of armed forces radio at Guam Naval Communications Station; reprint of article from Crossroads, a Navy publication, December 8, 1972.

1093 Barton, Hugh. "KUAM-Nearly 20 Years of Service to the Island," $G R$, n.s., 3, no. 1 (January-March 1973): 28-30.

Describes devclopment, facilities, and programming of KUAM AM-FM-TV; author is general manager of station.

1094 McGrath, Thomas B. "AFRN at AAFB-Youngster with Big Plans," $G R$, n.s., 3, no. 1 (January-March 1973): 38.

Short history of armed forces radio at Andersen Air Force Base.

\section{SATELLITE COMMUNICATION}

See also Pacific Islands General

1095 “PEACESAT Stalling Here,"' Pacific Daily News, May 14, 1973, 19.

Editorial discussing the problems that the University of Guam is having in obtaining financial assistance from the business community or island organizations for the PEACESAT project. 
1096 "Guam and the South Pacific Commission," Pacific Daily News, November 25, 1975, 19: 1.

Editor criticizes Guam for not joining PEACESAT system.

\section{TELEVISION}

1097 “Guam AM Fights Military TV There,” Broadcasting, 48, no. 22 (May 30, 1955): 96.

KUAM-TV station protests plans for establishing U.S. Army TV station citing "unfair government competition."

1098 “'Guam TV Dispute May Go Before FCC,” Broadcasting, 48, no. 23 (June 6, 1955): 60.

KUAM-TV says it could go out of business if advertisers get "free" advertising that is proposed for Army "morale" station.

1099 “KUAM Cites Maine TV Experiment,” Broadcasting, 49, no. 1 (July 4, 1955): 67.

Continuing legal developments in Guam TV station versus U.S. Army projected station.

1100 “Army Delays Guam TV Station,” NYT, July 12, 1955, 27: 6.

Plans for television station on Guam deferred at least one year.

1101 "'Speedy FCC Action Gives Guam Two VHF Channels," Broadcasting, 50, no. 11 (March 12, 1956): 72.

FCC announced its table of assignments; channels 8 and 10 assigned to Agana, Guam.

1102 Barton, Hugh. "KUAM-Nearly 20 Years of Service to the Island," Guam Recorder, n.s., 3, no. 1 (January-March 1973): 28-30.

General manager of KUAM AM-FM-TV describes the station's development, facilities, and programming.

1103 Holmes, Lee M. "The Promotion of a Broad Exchange of Programs on Cultural Education and Society-The Introduction of Chinese Television Programs to Guam on Cable TV," Proceedings of The First Asian Pacific Television Conference, June 23-29, 1975, Taipei, Republic of China. Seoul: Cultural and Social Center for the Asian and Pacific Region, pp. 113-15.

Article describes cable TV system on Guam and the Chinese Television Service programs shown on it. 


\section{Hawaii}

INDEXES, GUIDES, REFERENCE WORKS

1104 Aloha United Way. 1976 Hawaii Directory of Communications Media. Honolulu, $1976.46 \mathrm{pp}$.

Directory of newspapers, magazines, wire services, labor and military publications, radio and television stations, and communication-related organizations.

1105 Atlas of Hawaii. Honolulu: University Press of Hawaii, 1973. 222 pp.

Contains sections on satellite communication, television, radio, newspapers, educational television, periodicals.

1106 Broadcasting Yearbook. Washington: Broadcasting Publications, Inc. Annually since 1931 .

Lists radio and television stations and provides information on regulations, codes, programs, agencies and representatives, and networks.

1107 Handy, Willowdean C. "Newspapers Published in Hawaii: A Survey of the Holdings of the Hawaiian Historical Society and Other Honolulu Libraries." 1953. $52 \mathrm{pp}$. Mimeo.

Includes daily, semi-weekly, and weekly publications in English, Hawaiian, and Portuguese held by the Society; compares the Society's holdings and those of other libraries with total production of publications.

1108 Hawaii. Department of Education. Office of Library Services. Hawaii Documents. 1969-71 Cumulative Index, 1973, 350 pp.; 1972 Cumulative Index, 1973, $191 \mathrm{pp}$.

Lists state and county publications received by the Hawaii State Library System. Index to the Honolulu Advertiser and Honolulu Star-Bulletin. 1929-69, 6 vols.; annual volumes from 1970. 
1110 Department of Planning and Economic Development. State of Hawaii Data Book: A Statistical Abstract.

An annual source of statistical information on mass media coverage.

1111 Hawaii Library Association. Index to Periodicals of Hawaii, 2 vols. Honolulu, 1976. 1106 pp.

Consists of photocopies of index cards to local and Pacific-area periodicals in the Hawaii and Pacific section of the Hawaii State Library, covering approximately 1900 to 1969; provides an incomplete index to Aloha (formerly Hawaiian Digest), Army Navy Veteran Review, Beacon, Bulletin of the Pan Pacific Union, Friend, Hawaii, Hawaii Agriculture, Hawaii Farm \& Home, Hawaii Farm Science, Hawaii Medical Journal, Hawaiian Sportsman, Honolulu, Honolulu Mercury, Islander, Journal of the Pan-Pacific Research Institute, Mid-Pacific, Nisei, Pacific Features \& Sports, Pacific Science, Pan Pacific, Paradise of the Pacific, Plantation Health Bulletin, and Sales Builder.

1112 Hunt, James. "The Publication of an Index to the Honolulu Newspapers," Hawaii Library Association Journal, 26, no. 2 (December 1969): 12-14.

Discusses the compiling and printing of the index to the Honolulu Advertiser and Star-Bulletin.

1113 Hunter, Charles H., comp. Index to Publications of the Hawaiian Historical Society, 1892-1967. Honolulu: Hawaiian Historical Society, 1968. 84 pp.

1114 "Newspapers Published in Hawaii."

A 300-card file on Hawaii newspapers, mostly published before 1900. Cards generally include name, place, language, publication dates, editors, and historical commentary. In Hawaii collection, University of Hawaii Library.

1115 Johnson, Rubellite K., ed. Kukini 'Aha'ilono (Carry on The News). Honolulu: Topgallant Publishing Company, 1976. 436 pp.

Hawaiian-language texts and English translations of articles on history, culture, and politics published in Hawaiian newspapers between 1834 and 1948.

1116 comp. Ka Nupepa Ku'oko'a: A Chronicle of Entries, October 1861-September 1862. Honolulu: Topgallant Publishing Company, 1975. 235 pp.

Index to Ka Nupepa Ku'oko' $a$, arranged by column and page number, and giving Hawaiian title, English translation of title, and abstract in English.

1117 Kim, Hyung-chan, and Wayne K. Patterson. The Koreans in America, 1882-1974: A Chronology and Fact Book. Ethnic Chronology Series no. 16. Dobbs Ferry, N.Y.: Oceana Publications, 1974. 147 pp.

Chronology provides dates related to publishing activities of Koreans in Hawaii.

1118 Lau, Chau-Mun. "The Chinese in Hawaii: A Checklist of Chinese Materials in the Asian and Hawaiian Collections of the University of Hawaii Library." Honolulu: University of Hawaii Library, 1975. 55 pp.

Lists ten Chinese-language periodicals in the University of Hawaii collection.

1119 Mookini, Esther K. The Hawaiian Newspapers. Honolulu: Topgallant Press, 1974. 55 pp.

Annotated list of Hawaiian newspapers; foreword gives summary of newspaper publishing history.

1120 Park, Robert E. The Immigrant Press and Its Control. New York: Harper \& Brothers, 1922. 487 pp.

Reviews information on foreign-language press in United States; some information on the Japaneselanguage press. 
1121 Saiki, Patsy S. "An Appraisal of Newswriting Classes and School Newspapers in Oahu Public High and Intermediate Schools, 1958-1959.' M. Ed. thesis, University of Hawaii, 1959. 109 pp.

Study of effectiveness of Hawaii schools' newswriting classes.

1122 Saito, Shiro. The Overseas Filipinos: A Working Bibliography. Prepared for the Conference on Filipino Migration Sponsored by the East-West Center Population Institute, June 10-14, 1974. 57 pp.

Indexed under a variety of social, cultural and economic categories and by destinations such as Hawaii, Guam, mainland USA.

1123 Taehan Min'guk Kukhoe Tosogwan [Republic of Korea National Assembly Library]. Han'guk sinmun chapchi ch'ong mongnok: 1883-1945 [Catalogue of Korean Periodicals, 1883-1945]. Seoul, 1966. 230 pp.

Lists early Korean-language publications in Hawaii, giving names, dates, editors.

1124 Television Factbook. Washington: Television Digest, Inc. Annually since 1930.

Provides information on ownership, coverage, advertising, and technical aspects of television broadcasting stations and community-antenna systems; an index of publications on television; lists of educational institutions offering instruction in television and of professional organizations; information on program sources.

1125 Union List of Serials in Libraries of Honolulu, 3rd ed. Honolulu: Library Association of Hawaii, 1965. 624 pp.

1126 United States. Department of Commerce. Office of Minority Business Enterprise. Directory of Minority Media. Washington: Government Printing Office, 1973. 89 pp.

1127 Wymer, Lubomyr R. Encyclopedic Directory of Ethnic Newspapers and Periodicals in the United States. Littleton, Colorado: Libraries Unlimited, 1972. 260 pp.

NEWSPAPERS, PERIODICALS

ABBREVIATIONS USED IN THIS SECTION TO INDICATE THE LOCATION OF NEWSPAPER FILES OR MICROFILM COPIES

$\begin{array}{llll}\text { AH } & \text { Archives of Hawaii } & \text { HSL } & \text { Hawaii State Library } \\ \text { BM } & \text { Bishop Museum } & \text { KCL } & \text { Kauai County Library } \\ \text { BRM } & \text { British Museum } & \text { LC } & \text { Library of Congress } \\ \text { HHS } & \text { Hawaiian Historical } & \text { UCB } & \text { University of Califor- } \\ & \text { Society } & & \text { nia, Berkeley } \\ \text { HMCS } & \text { Hawaiian Mission } & \text { UH } & \text { University of Hawaii } \\ & \text { Children's Society } & & \end{array}$

1128 KA AHA ELEELE. See The Convention.

1129 KE ALAKAI O HAWAII. Honolulu. 1928-39. Weekly in Hawaiian. AH, BM, HHS. 
1130 KE ALOHA AINA. Honolulu. May 20, 1895-July 3, 1920. Weekly in Hawaiian. Succeeded Ka Nupepa Puka La Aloha Aina (September 30, 1893January 4, 1894), daily; Ka Nupepa Aloha Aina (June 6, 1894-January 5, 1895), weekly. HHS, BM, AH.

1131 ANOTHER VOICE. Honolulu. May 1972-January 1974. Biweekly. UH.

1132 KE AU HOU. See Hawaii Holomua.

1133 KE AU OKOA. Se Ka Nupepa Kuokoa.

1134 AURORA HAWAIIANA. See $O$ Lusu.

1135 AUSTIN'S HAWAIIAN WEEKLY. Honolulu. June 17, 1899-May 1900. Weekly. AH, BM, HHS.

1136 BEACON. Honolulu. February 1961-December 1973/January 1974. Monthly; frequency varied. UH.

1137 BENNETT'S OWN. See Hawaiian Times.

1138 THE CATHOLIC HERALD. Honolulu. November 1936- Weekly; official publication of the Catholic Diocese of Honolulu.

1139 CHUNG HUA HSIN PAO [United Chinese Press]. Honolulu. 1951—. Daily except Sunday, in Chinese.

1140 COMMERCIAL HAWAII. See Jitsugyō no Hawaii.

1141 COMMERCIAL TIMES. See Shōgyō Jihō.

1142 COMMUNICATION. Journal of the Communication Association of the Pacific. Honolulu. 1972 — . Irregular; published by Department of Speech, University of Hawaii.

1143 COMMUNITY REVIEW. Honolulu. 1974-. Monthly.

1144 THE CONVENTION (Ka Aha Eleele). Honolulu. July 14-August 31, 1864. Daily in Hawaiian and English published during debates of the 1864 convention. BM, HHS.

1145 DAILY BULLETIN. See Honolulu Star-Bulletin.

1146 DAILY HERALD. Honolulu. September 1, 1886-July 30, 1887. Daily. HHS, BM.

1147 DAILY HAWAIIAN. Honolulu. May 1, 1884-March 2, 1885. Daily. HHS, BM.

1148 DAILY HAWAIIAN HERALD. Honolulu. September 4-December 21, 1866. Daily. UH, HHS, UCB.

1149 DAILY HONOLULU PRESS. Honolulu. September 1, 1885-June 3, 1886. Daily. Combined Morning Guide (1884); Saturday Press, (September 4, 1880March 28, 1885), weekly. BM, HHS, UH, AH.

1150 DAILY PALI PRESS. See The Windward Sun Press. 
1151 DAILY POST-HERALD. See Hawaii Tribune-Herald.

1152 THE DEMOCRAT. Honolulu. October 25-November 8, 1910. Daily. HHS.

1153 DISPATCHER. Honolulu. July 3, 1944-December 3, 1945. Biweekly in Hawaiian; also published in San Francisco from 1942. UH.

1154 KA ELEELE. See Ka Leialii o Hawaii.

1155 KA ELEELE POAKOLU. See Ka Leialii o Hawaii.

1156 KA ELEELE POAOPO. See Ka Leialii o Hawaii.

1157 ECONOMIC SALON. See Economic World.

1158 ECONOMIC WORLD. Honolulu. April 1975-. Monthly. Titled Economic Salon (1968-March 1975), monthly.

1159 EVENING BULLETIN. See Honolulu Star-Bulletin.

1160 O FACHO. Honolulu. February 2, 1897—? Portuguese. AH.

1161 THE FRIEND. Honolulu. January 1843-June 1954; suspended March 1851April 1852. Missionary journal devoted to general social issues. AH, UH.

1162 FRIENDLY ISLE NEWS. Kaunakakai, Molokai. November 18, 1955January 25, 1957. Weekly. Succeeded Ka Leo o Molokai (December 8, 1950November 11, 1955), weekly.

1163 THE GARDEN ISLAND. Lihue, Kauai. July 1902-. Weekly, then semiweekly. UH, KCL.

1164 GARDEN NEWS. See Yoēn Jihō.

1165 KA HAE HAWAII. Honolulu. March 5, 1856-December 31, 1861. Weekly in Hawaiian; published by Department of Public Instruction. UH, AH, HHS, UCB.

1166 KA HAE HAWAII. Honolulu. April 16, 1910-August 10, 1912. Weekly in Hawaiian. HMCS, AH.

1167 O KA HAE KATOLIKA. Honolulu. May 1868-February 1871. Semimonthly in Hawaiian; published by Catholic Mission Press. HHS.

$1168 \mathrm{O}$ KA HAE KIRITIANO. Honolulu. January 1860-1863. Monthly in Hawaiian; published by Catholic Mission Press. UH.

1169 HAIMANAVA. Honolulu. January 1858-December 1859. Irregular in Hawaiian; published by Catholic Mission Press. HHS.

1170 HAWAII. Honolulu. August 1903-October 1904. Irregular in Japanese. UH.

1171 HAWAII. Honolulu. March 1940-June 1946. Bimonthly magazine. AH, UH.

1172 HAWAII AFL NEWS. Honolulu. December 4, 1952-June 4, 1953. Monthly. AH, UH.

1173 HAWAII BUSINESS. Honolulu. July 1955-. Monthly. 
1174 HAWAII CHINESE JOURNAL. Honolulu. 1937-57. Weekly in English. $\mathrm{UH}, \mathrm{AH}$.

Contents primarily related to social views of Chinese in Hawaii.

1175 HAWAII CHINESE WEEKLY. Honolulu. 1958-59. Weekly in English. UH.

1176 THE HAWAII DEMOCRAT. Honolulu. September 3-November 5, 1936. Weekly in English and Hawaiian. HHS.

1177 HAWAII FARM MONTHLY. Honolulu. 1937-? Monthly in English.

1178 HAWAII FREE PEOPLE'S PRESS. Honolulu. June 1969-December 1970. Irregular. Title varied: Hawaii Free Press. Superseded The Roach (May 1968-April 1969).

1179 HAWAII FREE PRESS. See Hawaii Free People's Press.

1180 HAWAII HERALD. Hilo. August 1895-December 28, 1905. Weekly in Hawaiian and English. UH, HHS.

1181 HAWAII HERALD. Honolulu. See Hawaii Hōchi.

1182 HAWAII HŌCHI. Honolulu. December 7, 1912—. Daily in Japanese and English. Titled Hawaii Herald (October 23, 1942-January 11, 1952). UH, LC.

1183 HAWAII HOLOMUA. Honolulu. May 2, 1891?-January 1895. Weekly in Hawaiian (1892-94); daily in English (1893-95). UH, AH, HHS.

1184 HAWAII HOLOMUA. n.s. Honolulu. March 6-December 4, 1912. Weekly in Hawaiian; superseded $\mathrm{Ke} \mathrm{Au} \mathrm{Hou} \mathrm{(May} \mathrm{1910-February} \mathrm{28,} \mathrm{1912).} \mathrm{UH,} \mathrm{BRM.}$

1185 HAWAII JOURNALISM REVIEW. Honolulu. February 1971-April 1973. Irregular. UH, HSL.

1186 HAWAII KAI SUN PRESS. Kaneohe. November 1972—. Weekly.

1187 HAWAII KUKALA PILI AUPUNI. Honolulu. February 7-June 27, 1887. Weekly in Hawaiian and English; government gazette. AH.

1188 HAWAII LABOR NEWS. Honolulu. September 3, 1953-June 1957. AH, UH.

1189 HAWAII MAINICHI SHINBUN. Hilo. 1909-December 1941. Daily except Sunday, in Japanese.

1190 HAWAII MAINICHI SHINBUN. Honolulu. 1952-April 1965. Weekly in Japanese. UH.

1191 HAWAII MEDIA. Honolulu. September 1974-. Quarterly. UH.

Lists current publications, radio and television stations; advertising rates.

1192 HAWAII MILITARY SUN PRESS. Kaneohe. February 1972-. Weekly. Superseded Military Sun Press (1959-January 1972), weekly.

1193 HAWAII OBSERVER. Honolulu. February 19, 1973 — . Biweekly. UH.

1194 HAWAII POST. See Hawaii Tribune-Herald. 
1195 HAWAII PROGRESS HOLOMUA. Honolulu. Daily. September 18, 1893-1895. HHS.

1196 HAWAII PUKA LA HOLOMUA. Honolulu. 1892-94. Daily in Hawaiian. BM, HHS.

1197 HAWAII SENTINEL. Honolulu. May 16, 1935-October 16, 1947. Weekly. $\mathrm{UH}, \mathrm{AH}$.

1198 HAWAII SHINPŌ. Honolulu. 1894-1941. Daily except Sunday (1894-1926); weekly (1932-1941). In Japanese. Files held by Hilo Times.

1199 HAWAII SPORTS MAGAZINE. Honolulu. July 1968-October 1973? Monthly.

1200 HAWAII STAR. See Honolulu Record.

1201 HAWAIIAN TEAMSTER. Honolulu. March 1949?-December 1950? Monthly. AH, UH.

1202 HAWAII TIMES. Honolulu. October 15, 1895-. Daily except Sunday, in Japanese. Superseded Yamato (October 1895-July 1896); Yamato Shinbun (August 1896-November 2, 1906); Nippu Jiji (November 3, 1906-October 6, 1942) but suspended December 12, 1941-January 9, 1942; Hawaii Times since October 28, 1942. UH, AH.

1203 HAWAII TRIBUNE-HERALD. Hilo. January 1923 - Daily except Saturday. Superseded Hilo Tribune (November 23, 1895-June 27, 1917), weekly; Hilo Daily Tribune (September 1913-December 1922); Today's News (1912-16), daily?; Hawaii Post (November 1, 1916-December 1, 1917) daily; Daily Post-Herald (December 3, 1917-February 17, 1923). UH, HHS, HCL.

1204 THE HAWAIIAN. Honolulu. February 12-November 25, 1898. AH, BM.

1205 HAWAIIAN-AMERICAN. Honolulu. 1937. Weekly in Hawaiian and English. HHS.

1206 HAWAIIAN COMMERCIAL JOURNAL AND MARITIME REPORT. Honolulu. 1895-1897. Weekly. HHS.

1207 HAWAIIAN GAZETTE. Honolulu. January 21, 1865-November 29, 1918. Weekly, semiweekly. UH, AH, LC, UCB.

1208 HAWAIIAN SPECTATOR. Honolulu. January 1838-October 1839. Quarterly. HSL, UH.

1209 HAWAIIAN STAR. See Honolulu Star-Bulletin.

1210 HAWAIIAN TIMES. Honolulu. September 6-December 30, 1870. Semiweekly. Superseded Bennett's Own (September 15, 1869-September 6, 1870), weekly. AH, HHS. 
1211 HERALD. Honolulu. July 4, 1941-1942? Weekly. Suspended December 2, 1941-March 8, 1942; March 30, 1942-April 22, 1942. Superseded Kauai Herald, published at Hanapepe, Kauai (July 12, 1940-June 16, 1941). Successor to the Herald was Victory (April 22, 1942-?).

1212 HILO DAILY TRIBUNE. See Hawaii Tribune-Herald.

1213 HILO RAIN. Hilo. 1976-. Biweekly.

1214 HILO TIMES. Hilo. May 1955 —. Semiweekly in Japanese.

1215 HILO TRIBUNE. See Hawaii Tribune-Herald.

1216 HILO TRIBUNE-HERALD. See Hawaii Tribune-Herald.

1217 KA HOALOHA. Honolulu. June 1902 - Publication varied: monthly until 1943; then weekly; later quarterly, in Hawaiian. Published by the Hawaiian Board. HMCS.

1218 KA HOKU LOA O HAWAII. Honolulu. July 2-September 18, 1856. Weekly Hawaiian page in Pacific Commercial Advertiser.

1219 KA HOKU O HAWAII. Hilo. May 1906-1948. Weekly in Hawaiian. UH, HHS.

1220 KA HOKU O KA PAKIPIKA. Honolulu. September 26, 1861-May 14, 1863. Weekly in Hawaiian. UH, AH, HHS, BRM.

1221 KA HOKU PAKIPIKA. Honolulu. July 9, 1904-. Monthly in Hawaiian. HMCS.

1222 KA HOLOMUA. Honolulu. January 16, 1915-January 15, 1919. Weekly in Hawaiian. BM.

1223 HOME RULA REPUBLALIKA. Honolulu. November 2, 1901-March 15, 1902. Semiweekly in Hawaiian and English. BM.

1224 HONOLULU. Honolulu. 1966-. Monthly. Superseded Paradise of the Pacific (January 1888-December 1962), monthly.

1225 HONOLULU ADVERTISER. Honolulu. July 2, 1856-. Daily since 1888. Superseded Pacific Commercial Advertiser (July 2, 1856-March 30, 1921). From July 1, 1962 the Advertiser combined its Sunday Advertiser with the Honolulu StarBulletin's Sunday edition to form the Sunday Star-Bulletin \& Advertiser. UH, AH, LC.

1226 HONOLULU CHRONICLE. See Waikiki-Kaimuki Chronicle.

1227 HONOLULU DAILY TIMES. Honolulu. January 25-February 3, 1890. HHS.

1228 HONOLULU RECORD. Honolulu. August 1948-July 1958. Weekly. Superseded Hawaii Star (March 6, 1947-April 1948).

1229 HONOLULU REPUBLICAN. Honolulu. June 14, 1900-1902. Daily. UH, AH, HHS. 
1230 HONOLULU STAR-BULLETIN. Honolulu. July 1, 1912-. Daily except Sunday (1912-October 31, 1959); daily since. Superseded Hawaiian Star (March 28, 1893-June 30,1912), published daily except Sunday. Also superseded the daily Evening Bulletin (February 1, 1882-June 30, 1912); title varied to Daily Bulletin (February 1, 1882-May 16, 1895). The Sunday editions of the Honolulu Advertiser and the Honolulu Star-Bulletin merged to form the Sunday Star-Bulletin \& Advertiser from July 1, 1962. AH, BM, UH, HHS.

1231 HONOLULU TIMES. Honolulu. January 8, 1849-July 1851 . Weekly. UH, BRM, HHS, BM.

1232 KA HOOLAHA MANAOIO. Honolulu. January 1882-1928. In Hawaiian; published by Catholic Mission Press. HMCS.

1233 HSIN CHUNG KUO JIH PAO [New China Daily News]. Honolulu. September 5, 1900-. Daily except Sunday, in Chinese.

1234 ILWU REPORTER. Honolulu. February 16, 1949-December 21, 1960. Monthly. AH, UH.

1235 INDEPENDENT. Honolulu. June 24, 1895-October 31, 1905. Daily except Sunday. UH, AH, HHS, BM.

1236 THE ISLANDER. Honolulu. March 5-October 29, 1875. Weekly. AH, HHS, $\mathrm{UH}$.

1237 JITSUGYO NO HAWAII [Commercial Hawaii]. Honolulu. July 1912November 1941. Monthly in Japanese. UH.

1238 KE KAHUNAAO. Honolulu. 1913-21. Quarterly in Hawaiian; published for ministers by the Hawaiian Board. HMCS.

1239 KAIMUKI CHRONICLE. See Waikiki-Kaimuki Chronicle.

1240 KA'U NEWS. Pahala, Hawaii. January 1972—. Semimonthly.

1241 KAUAI HERALD. See Herald.

1242 KE KIAI. Honolulu. September 1902-? Semiweekly in Hawaiian and English. HMCS.

1243 KE KIAI O KA LAHUI. January-December 1890. Daily in Hawaiian. HHS.

1244 KE KILOHANA O KA MALAMALAMA. Hilo. 1907-19. Weekly in Hawaiian. AH.

1245 KO HAWAII PAE AINA. See Ka Nupepa Kuokoa.

1246 KO HAWAII PONOI. Honolulu. June 18, 1873-June 10, 1874. Weekly in Hawaiian. UH, BM, BRM.

1247 KOHALA MIDGET. See Midget.

1248 KONA ECHO. Holualoa and Kailua, Hawaii. February 3, 1897-July 7, 1951. Frequency varied: biweekly, monthly, bimonthly; begun as Japanese-language paper, later bilingual, and from June 20, 1940, English only. HHS, UH. 
1249 KONA STAR. Kailua-Kona, Hawaii. 1967-? Weekly.

1250 KONA TIMES. Kailua-Kona, Hawaii. October 31, 1969-June 3, 1971. Weekly.

1251 KONA TORCH. Kailua-Kona, Hawaii. July 1961-April 1968; July 1968-. Weekly.

1252 KONA TRIBUNE-HERALD. See West Hawaii Today.

1253 KE KOO O HAWAII. See Ke Ola o Hawaii.

1254 KOOK MIN BO [Korean National Herald]. Honolulu. August 1, 1913December 25, 1968. Weekly. Published jointly with T'aep'yongyang Chubo from January 21, 1942 to February 2, 1944. Partial collections at UH and Kook Min Hur headquarters, Honolulu.

1255 KOOK MIN BO-T'AEP'YǑNGYANG CHUBO [Korean National HeraldPacific Weekly]. Honolulu. January 21, 1942-February 2, 1944. Combined the separate publications of the Kook Min Hur and Dong Ji Hoi, Korean civic organizations. Complete file at Kook Min Hur headquarters, Honolulu.

1256 KOREAN NATIONAL HERALD. See Kook Min Bo.

1257 KOREAN NATIONAL HERALD-PACIFIC WEEKLY. See Kook Min BoT'aep'yongyang Chubo.

1258 KOREAN PACIFIC WEEKLY. See T'aep'yorngyang Chubo.

1259 KE KUMU HAWAII. Honolulu. November 12, 1834-May 22, 1839. Semimonthly in Hawaiian; published by Mission Press. HHS, UH.

$1260 \mathrm{KE}$ KUMU KAMALII. Honolulu. January-December 1837. Monthly in Hawaiian; published by Mission Press. UH.

1261 KUU HAE HAWAII. Honolulu. April 19-July 4, 1913. Weekly in Hawaiian. UH, BM, BRM.

1262 KWAZAN [The Volcano]. Hilo. 1914-42. Semiweekly, later daily except Sunday in Japanese. Hilo Times has issues of July 1 to August 26, 1939.

1263 KA LA O HAWAII. August 1, 1884-? Weekly in Hawaiian and English. HMCS.

1264 LAHAINA SUN. See Maui Sun.

1265 LAHUI HAWAII. Honolulu. January 28, 1899-1905. Daily in Hawaiian. BM.

1266 KA LAMA HAWAII. Lahainaluna, Maui. February 14-December 26, 1834. Weekly in Hawaiian. UH, HHS.

Ka Lama Hawaii was the earliest periodical published in Hawaii.

1267 KA LANAKILA. Honolulu. July 1-October 21, 1909. Weekly in Hawaiian. UH, HHS, HMCS, BRM. 
1268 KA LAU OLIVA. Honolulu. January 1, 1871-December 1873. Monthly in Hawaiian; publication of the Stone Church. HMCS.

1269 LEEWARD \& WAHIAWA SUN PRESS. See Wahiawa Sun Press.

1270 LEEWARD SUN PRESS. Kaneohe. March 1972—. Weekly.

1271 KA LEI MOMI. See Ka Makaainana.

1272 KA LEI ROSE O HAWAII. Honolulu. February 15-September 1, 1898. Semiweekly in Hawaiian. UH, BM, BRM.

1273 KA LEIALII O HAWAII. Honolulu. April 23-August 23, 1892? Weekly. Superseded Ka Eleele Poakolu (September 8, 1880-August 31, 1881); weekly in Hawaiian and English; Ka Nupepa Poakolu (April 28, 1882-April 15, 1885); Ka Eleele Poaopo (June-December 1885); Ka Eleele (December 12, 1885-April 16, 1892). HHS, BM, UH.

1274 KA LEO O HAWAII. Honolulu. September 13, 1922—. Frequency varies; student newspaper of the University of Hawaii-Manoa. UH.

1275 KA LEO O HILO. Hilo. February 19, 1954—. Frequency varies. Superseded Ka Leoiki (October 22, 1947-May 23, 1949).

1276 KA LEO O KA LAHUI. Honolulu. August 19, 1889-April 13, 1896. Daily in Hawaiian; English added from 1890. HHS.

1277 KA LEO O MOLOKAI. See Friendly Isle News.

1278 KA LEOIKI. See Ka Leo o Hilo.

1279 THE LIBERAL. Honolulu. September 9, 1892-April 15, 1893. Semiweekly in Hawaiian and English. UH, AH, HHS.

1280 KA LOEA KALAIAINA. Honolulu. 1897-January 13, 1900. Weekly in Hawaiian; publication of the Home Rule party. BM.

1281 O LUSO. Honolulu. February 15, 1896-January 31, 1924. Weekly in Portuguese. Superseded $O$ Luso Hawaiiana (August 15, 1885-December 13, 1890); Aurora Hawaiiana (August 3, 1889-March 28, 1891); A Sentinella (April 22, 1892-1896); A Uniao Lusitana-Hawaiiana (March 5, 1892-February 1, 1896). AH, $\mathrm{UH}, \mathrm{HHS}$.

1282 O LUSO HAWAIIANO. See $O$ Luso.

1283 KA MAKAAINANA. Honolulu. November 1, 1887-1893. Daily, 1887-89; weekly, 1889-93. In Hawaiian. UH, BM, BRM.

1284 KA MAKAAINANA. Honolulu. January 1, 1894-1902. Weekly in Hawaiian. Superseded Ka Lei Momi (June 21, 1893-December 25, 1893), daily, later weekly. UH, BM, BRM.

$1285 \mathrm{KA}$ MANAWA. Honolulu. November 7-December 12, 1870. Weekly in Hawaiian. BM. 
1286 MAUI NEWS. Wailuku, Maui. February 1900 —. Triweekly; then semiweekly. AH, UH, HHS, LC.

1287 THE MAUI SUN. Lahaina, Maui. 1970-. Weekly. Titled Lahaina Sun (1970-August 29, 1973).

1288 MIDGET. Kohala, Hawaii. October 1, 1913-April 25, 1917. Weekly. Superseded Kohala Midget (September 19, 1908-September 24, 1913). AH, UH, HHS.

1289 MID-PACIFIC MAGAZINE. Honolulu. January 1911-December 1936; April 1954-. Monthly; published by the Pan-Pacific Union. Titled Pan-Pacific Magazine (January 1937 to September 1941), quarterly. UH.

1290 MILITARY SUN PRESS. See Hawaii Military Sun Press.

1291 MOLOKAI REPORTER. Maunaloa, Molokai. November 5, 1969-March 4, 1970. Semimonthly.

1292 KA MOMI O HAWAII. Honolulu. January 1-April 16, 1913. Weekly in Hawaiian. BM.

1293 THE MONITOR. Honolulu. January 18-December 22, 1845. Monthly. UH.

1294 MORNING GUIDE. See Daily Honolulu Press.

1295 MUNICIPAL RECORD. Honolulu. 1912. Weekly. HHS.

1296 KA NA'I AUPUNI. Honolulu. November 27, 1905-April 24, 1908. Daily in Hawaiian. BM.

1297 THE NATIONAL HERALD. Honolulu. January-February 1890. Daily in Hawaiian and English. HHS.

1298 NEW CHINA DAILY NEWS. See Hsin Chung Kuo Jih Pao.

1299 NEW ERA AND WEEKLY ARGUS. Honolulu. October 22, 1853-June 28, 1855. Weekly. Superseded Weekly Argus (January 21, 1852-October 15, 1853). AH, HHS, BM.

1300 THE NEW PACIFIC. Honolulu. November 1943-June 1948. Monthly. Title varied: Pacific Features and Sports.

1301 NIPPU JIJI. See Hawaii Times.

1302 KA NONANONA. Honolulu. July 6, 1841-March 18, 1845. Bimonthly in Hawaiian.

1303 NUHOU. Honolulu. February 25, 1873-April 28, 1874. Semiweekly, then weekly in Hawaiian and English. Titled Ka Nuhou Hawaii (October 1873-April 1874). HHS, UH, BM.

1304 KA NUHOU. Honolulu. March 11-August 1954. Weekly in Hawaiian; published by Mission Press. BM.

1305 KA NUHOU HAWAII. See Nuhou. 
1306 KA NUPEPA ALOHA AINA. See Ke Aloha Aina.

1307 KA NUPEPA KA OIAIO. Honolulu. May 24, 1889-September 1896 . Weekly, later daily in Hawaiian. HHS.

1308 KA NUPEPA KUOKOA. Honolulu. October 1861-December 29, 1927. Weekly in Hawaiian. Superseded $K e$ Au Okoa (April 24, 1865-March 27, 1873), weekly; Ko Hawaii Pae Aina (January 5, 1878-October 9, 1891), weekly. AH, UH, HHS, BM, BRM.

1309 KA NUPEPA KUOKOA PUKA LA. Honolulu. May 24, 1919-? Daily in Hawaiian.

1310 KA NUPEPA LA KO HAWAII PAE AINA. See Ka Nupepa Puka La Kuokoa Me Ko Hawaii Pae Aina I Huila.

1311 KA NUPEPA POAKOLU. See Ka Leialii o Hawaii.

1312 KA NUPEPA PUKA LA ALOHA AINA. See Ke Aloha Aina.

1313 KA NUPEPA PUKA LA KUOKOA ME KO HAWAII PAE AINA I HUIIA. Honolulu. January 5, 1893-1896? Daily in Hawaiian. Superseded Ka Nupepa La Ko Hawaii Pae Aina (May 7, 1884-April 4, 1891). HHS.

1314 OFFICIAL AND COMMERCIAL RECORD. Honolulu. March 2, 19031907. Semiweekly. AH, HHS.

1315 KE OLA O HAWAII. Honolulu. February 2-July 19, 1884. Weekly in Hawaiian. Superseded Ke Koo o Hawaii (August 15-December 1883), biweekly. $\mathrm{BM}, \mathrm{UH}$.

1316 KE OLA O HAWAII. Hilo. December 28, 1916-February 13, 1919. Weekly in Hawaiian. BM.

1317 PACIFIC BUSINESS NEWS. Honolulu. 1963-. Weekly. UH.

1318 PACIFIC COMMERCIAL ADVERTISER. See Honolulu Advertiser.

1319 PACIFIC COURIER. Honolulu. February 1967-. Semimonthly.

1320 PACIFIC FEATURES AND SPORTS. See The New Pacific.

1321 PALI PRESS. See The Windward Sun Press.

1322 PAN-PACIFIC MAGAZINE. See Mid-Pacific Magazine.

1323 PARADISE MAGAZINE. Honolulu. December 1973-March 1975. HSL.

1324 PARADISE NEWS. See Yón Jihō.

1325 PARADISE OF THE PACIFIC. See Honolulu.

1326 PHILIPPINE-AMERICAN PRESS. Honolulu. April-May 1960. Monthly.

1327 THE POLYNESIAN. Honolulu. June 6, 1840-February 6, 1864. Weekly; suspended December 18, 1841-May 11, 1844. AH, UH, HHS, LC. 
1328 O POPULAR. Honolulu. July 20, 1911-January 2, 1913. Weekly in Portuguese. AH, UH, HHS.

1329 KA PUUHONUA O NA HAWAII. Honolulu. 1914-28? Weekly in Hawaiian. BM.

1330 THE ROACH. See Hawaii Free People's Press.

1331 THE SALES BUILDER. Honolulu. 1930-41. Monthly; published by the StarBulletin Printing House. UH.

1332 SANDWICH ISLANDS GAZETTE AND JOURNAL OF COMMERCE. See Sandwich Islands Mirror and Commercial Gazette.

1333 SANDWICH ISLANDS MIRROR AND COMMERCIAL GAZETTE. Honolulu. August 15, 1839-July 15, 1840. Monthly. Superseded Sandwich Islands Gazette and Journal of Commerce (July 30, 1836-July 27, 1839), weekly. AH, UH, HHS.

The Sandwich Islands Gazette and Journal of Commerce was the first newspaper of general circulation in Hawaii.

1334 SANDWICH ISLANDS MONTHLY MAGAZINE. Honolulu. January-June 1856.

1335 SANDWICH ISLANDS NEWS. Honolulu. September 2, 1846-April 14, 1849. Weekly. AH, UH, HHS.

1336 SATURDAY PRESS. See Daily Honolulu Press.

1337 A SENTINELLA. See $O$ Luso.

1338 A SETTA. Hilo, 1903-21. Weekly in Portuguese. UH, AH, HHS.

1339 SHIMIN [The Citizen]. Honolulu. June 1954 - Monthly in Japanese and English; published by Citizen Study Club of Oahu. UH.

1340 SHŌGYŌ JIHŌ [Commercial Times]. Honolulu. August 1921—. Monthly in Japanese; suspended November 1941-November 1946. UH.

1341 SHŪKAN TIMES [Weekly Times]. Honolulu. May 1959-August 1964. Weekly in Japanese. UH.

1342 THE SPOKESMAN. Honolulu. 1902. Weekly. HHS.

1343 THE SUN. See Taiyō.

1344 SUNDAY ADVERTISER. See Honolulu Advertiser.

1345 SUNDAY STAR-BULLETIN \& ADVERTISER. See Honolulu Star-Bulletin or Honolulu Advertiser.

1346 SUNDAY VOLCANO. Honolulu. 1899-1901. Weekly. HHS.

1347 T'AEP'YONGYANG CHAPCHI. See T'aep'yongyang Chubo. 
1348 T'AEP'YONGYANG CHUBO [Korean Pacific Weekly]. Honolulu. December 13, 1930-February 6, 1970. Superseded T'aep'yongyang Chapchi [Korean Pacific Magazine] (September 20, 1913-December 13, 1930), published irregularly, usually monthly. Published in combined edition as Kook Min Bo-T'aep'yongyang Chubo from January 21, 1942 to February 2, 1944. Partial collections at UH, LC, Dong Ji Hoe headquarters, Honolulu.

1349 TAIYŌ [The Sun]. Hilo. August-October 1950. Weekly in Japanese. Hilo Times has file.

1350 THE TIME. Honolulu. April 27, 1895-January 4, 1896. Weekly. HHS.

1351 TODAY'S NEWS. See Hawaii Tribune-Herald.

1352 TROPIC TOPICS. Honolulu. October 5, 1912-January 3, 1914. Weekly. HHS.

1353 TRUTH. Honolulu. June 15?-October 7, 1949. Irregular, in Filipino and English. AH, UH.

1354 A UNIAO LUSITANA-HAWAIIANA. See $O$ Luso.

1355 UNITED CHINESE PRESS. See Chung Hua Hsin Pao.

1356 VICTORY. See Herald.

1357 VOICE OF THE ILWU. Honolulu. January 18, 1961—. Published monthly by the International Longshoremen's and Warehousemen's Union. State Historical Society of Wisconsin (Madison), UH.

1358 VOICE OF LABOR. Honolulu. November 4, 1935-July 6, 1939. Weekly. UH.

1359 THE VOLCANO. See Kwazan.

1360 WAHIAWA SUN PRESS. Kaneohe. March 1972_. Weekly. Continues in part the Leeward \& Wahiawa Sun Press (1972), weekly.

1361 WAIKIKI BEACH PRESS. Honolulu. July 1955—. Weekly; then semiweekly.

1362 WAIKIKI CHRONICLE. See Waikiki-Kaimuki Chronicle.

1363 WAIKIKI-KAIMUKI CHRONICLE. Honolulu. November 9, 1947-May 3, 1949. Weekly. Title varied: Honolulu Chronicle, Kaimuki Chronicle, Waikiki Chronicle.

1364 WEEKLY ARGUS. See New Era and Weekly Argus.

1365 WEEKLY TIMES. See Shūkan Times.

1366 WEST HAWAII NEWS. Keauhou, Hawaii. October 1951-May 20, 1953. Monthly, then semimonthly. 
1367 WEST HAWAII TODAY. Kainaliu, Hawaii. July 31, 1968_. Weekly. Superseded Kona Tribune-Herald, published at Hilo (August 5, 1964-July 24, 1968).

1368 WINDWARD REPORTER. Kailua, Oahu. February 15, 1951-April 13, 1960. Weekly.

1369 WINDWARD PRESS. Kailua, Oahu. June 21-28, 1951 (two issues).

1370 THE WINDWARD SUN PRESS. Kailua, Oahu. February 2, 1972_. Weekly. Superseded Pali Press (June 13, 1958-January 26, 1972), weekly; and Daily Pali Press (January 10-December 30, 1966).

1371 THE WINDWORD. Kailua, Oahu. August 15, 1974_. Biweekly.

1372 YAMATO. See Hawaii Times.

1373 YAMATO SHINBUN. See Hawaii Times.

1374 YŌEN JIHŌ [Garden News]. Koloa, Kauai; then Honolulu. 1921-April 30, 1970. Frequency varied, generally weekly, in Japanese. UH.

\section{BIOGRAPHIES}

1375 Allen, Riley H. “'Wallace R. Farrington, Newspaperman.” Honolulu: Honolulu Star-Bulletin Printing Co., 1937. 22 pp. Reprinted from the 25 th Anniversary Edition of the Honolulu Star-Bulletin, July 1, 1937.

Career of W. R. Farrington as it involved the Honolulu Star-Bulletin.

1376 Black, Cobey. “Man Behind the News,”'Honolulu Beacon, September 1963, pp. 16-19.

Interview with William Ewing, editor of Honolulu Star-Bulletin.

1377 Damon, Ethel M. Samuel Chenery Damon: Chaplain and Friend of Seamen, Historian, Traveler, Diplomat, Doctor of Divinity, Journalist, Genial Companion, Genealogist. Honolulu: Hawaiian Mission Children's Society, 1966. 141 pp.

Story of the life and activities of the writer's grandfather, Samuel C. Damon, 1815-85.

1378 Davis, Eleanor H. "Abraham Fornander and the Sandwich Islands Monthly Magazine," Hawaiian Journal of History, 6 (1972):107-28.

1379 Day, A. Grove. What Did I Do Right? An Auto-Bibliography. Honolulu: Privately printed, 1974. $70 \mathrm{pp}$.

Autobiography of a writer, printer, and printing historian of Hawaii.

1380 Dutton, Mereic K. Henry M. Whitney: Pioneer Printer-Publisher and Hawaii's First Postmaster. Honolulu: Loomis House Press and Hale Pai o Lumiki, 1955. $20 \mathrm{pp}$.

The life of Henry M. Whitney and his association with the Honolulu Advertiser.

1381 Hardy, Thornton S. Wallace Rider Farrington. Honolulu: Honolulu StarBulletin Printing Co., 1935. 202 pp.

The life of W. R. Farrington and his association with the Pacific Commercial Advertiser and the Evening Bulletin. 
1382 “'History Parallels Hawaii's Growth," $A D V$, July 2, 1941, II, pp. 2-3.

History of the Honolulu Advertiser and biographical sketch of Henry M. Whitney, founder and first publisher of the Pacific Commercial Advertiser.

1383 Hoyt, Helen P. “'Hawaii's First English Newspaper and Its Editor,' Hawaiian Historical Society Report, 1954, pp. 5-18.

History of the Sandwich Island Gazette and Journal of Commerce and biography of its editor, Stephen D. Mackintosh.

1384 Kim Hyðn-gu (Henry C. Kim). “Kim Hyðn-gu chasojon”' [Autobiography of Kim Hyon-gu]. Unpublished manuscript. 1966. Center for Korean Studies, University of Hawaii.

Kim was for many years editor of the Korean-language newspaper Kook Min Bo.

1385 Makino Kenzaburo Den Hensan Iinkai [Compilation Committee for the Publication of Kinzaburo Makino's Biography], ed. Makino Kenzaburō Den [The Life of Kinzaburo Makino]. Honolulu, 1965. 143, 160 pp.

Biographical sketches in Japanese and English of the founder and president of Hawaii Hochi.

1386 "Master Builder of the Advertiser Had Remarkable Career in Law, Statecraft, Business and Science," $A D V$, July 2, 1931, II, pp. 4-6.

Biographical sketch of Lorrin A. Thurston, including his association with the Gazette and the Pacific Commercial Advertiser and his part in the establishment of KGU radio.

1387 Mayo, Donald S. "Island Profile: Yasutaro Soga," Paradise of the Pacific, 69, no. 4 (April 1957): 26, 31.

Sketch of the president and editor of the Hawaii Times.

1388 Sizer, Theodore. “James Jackson Jarves," The New England Quarterly, June 1933, pp. 328-52.

Sketch of the career of the editor of the Polynesian and director of the Hawaiian government press.

1389 Steegmuller, Francis. The Two Lives of James Jackson Jarves. New Haven: Yale University Press, 1951. 331 pp.

Biography of J. J. Jarves (1818-88), editor of the Polynesian, a weekly newspaper established in 1840 . 1390 “Thurston's Mark on Isle History," $A D V$, July 2, 1941, p. 3.

Biographical sketch of Lorrin A. Thurston, including some discussion of his editorial stands.

1391 “25 Editors Over 100 Years,” $A D V$, July 1, 1956, I-2: 1.

Lists former editors of the Honolulu Advertiser with additional background on the more prominent ones.

\section{CINEMA}

1392 “'Lights! And Give 'em a Hand," The Sales Builder, 10, no. 1 (January 1937): 2-13.

A history of theatrical enterprise in Hawaii, including cinema.

1393 ، “Joyita' To Be Filmed Soon,” PIM, 33, no. 4 (November 1962): 71.

Reports Kailua-Kona region to be setting for film about Western Samoa event.

1394 Schmitt, Robert C. "Movies in Hawaii, 1897-1932," Hawaiian Journal of History, vol. 1 (1967): 73-82. 
1395 "South Seas Movies, 1913-1943," Hawaiian Historical Review, 1, no. 11 (April 1968): 433-52.

Analysis of themes in 132 motion pictures about Hawaii, Melanesia, Micronesia, and Polynesia released in the United States before July 1, 1943.

1396 “Movie House Battles Cable TV," PICN, 4, no. 1 (August 1973): 10.

Brief article on competition for audiences on the island of Hawaii.

1397 Sullam, Brian. "Who Is Oscar Nichols?" Hawaii Observer, no. 37 (August 6, 1974): 1-2.

First of two-part series. "The Oscar Nichols Saga," Hawaii Observer, no. 38 (August 20, 1974): 1-2.

Second of a two-part series of articles on a project to establish a motion picture studio in Hawaii.

\section{COMMUNICATION RESEARCH}

1399 McKinney, Albert J. "A Study of the Treatment of Education in the Daily Newspapers of Hawaii," M.Ed. Thesis, University of Hawaii, 1940. 121 pp.

A study of the positions taken from 1930 to 1939 on education in the editorial columns and letters of four Honolulu daily papers: the Honolulu Advertiser, Honolulu Star-Bulletin, and the Englishlanguage sections of Hawaii Hochi and Nippu Jiji.

1400 Territorial Surveys. A Public Opinion Analysis of Media and Communication in Hawaii. Honolulu. September 1948.69 pp.

A public opinion analysis of radio, local newspapers, comic books, testing for source credibility, ability to speak or understand English, and other measures with about 1200 respondents.

1401 Hormann, Bernhard L. "The Significance of the Wilder or Major-Palakiko Case, A Study in Public Opinion," Social Process in Hawaii, vol. 17 (1953): 1-13.

Examines the 1948 Major-Palakiko murder case as an index of race relations in Hawaii and as a case study in how issues arise and are handled in a complex urban community; includes discussion of the role of newspapers in forming opinions regarding the case.

1402 Nakasone, Henry I. "Propaganda Techniques Employed in IMUA and ILWU Radio Broadcasts." M.A. Thesis, University of Hawaii, 1956. 179 pp.

A content analysis applying value-analysis technique to twenty broadcasts each of the Hawaii Residents' Association (IMUA) and the International Longshoremen's and Warehousemen's Union (ILWU) presented between the October 2 primary election and the November 2 general election in 1954. The study seeks to identify specific propaganda devices used, the values emphasized in each program, and the way various devices are used.

1403 Honolulu Star-Bulletin. Research Division. "Household Income and Expenditures and Newspaper Penetration on Oahu, 1960." 10 pp.

Stated purpose of paper: to show how Oahu household incomes are distributed; income distribution among various racial groups; annual median household expenditures by income and race; and extent of newspaper penetration.

1404 "Survey Shows Readers Prefer Star-Bulletin," Sunday Star-Bulletin, May 28, 1961, 1: 2, 2: 1.

Survey shows popularity of major Honolulu dailies; information on readership by income levels, number of daily papers subscribed to in Honolulu, etc. 
1405 Gordon, J. "Television Education in Elementary School Speech Improvement," Speech Monographs, 33 (March 1966): 57-64.

Four-month study of third-grade students in Hawaii using thirty 15 -minute biweekly TV programs. Gordon found that the combination of televised and non-televised speech improvement lessons improved the students' performance significantly.

1406 Anderson, William A. Seismic Sea-Wave Warning in Crescent City, California, and Hilo, Hawaii. Research Report no. 13. Columbus: Disaster Research Center, Ohio State University, 1967.27 pp.

Study compares the warning system, community responses, and actions of officials in two earthquakes a year apart in two different communities; reference to news media.

1407 Norris, Stephen S. "The Pseudo-Event in the Honolulu Advertiser and the Honolulu Star-Bulletin." Honors Program Paper. University of Hawaii, 1967. 30 pp.

Paper discusses instances in which the Honolulu Advertiser and Honolulu Star-Bulletin did not provide a "meaningful" report of current affairs.

1408 Weinberg, Daniel E. "The Movement to 'Americanize' the Japanese Community in Hawaii: An Analysis of One Hundred Per Cent Americanization Activity as Expressed in the Caucasian Press, 1919-1923." M.A. Thesis, University of Hawaii, 1967. 142 pp.

See especially chapter four for discussion of attempts to discredit the Japanese-language press and government measures to control Japanese-language newspapers.

1409 Dordick, H. S., and J. Lyle. "Access by Local Political Candidates to Cable Television: A Report of an Experiment." Rand Corporation Report R-881-MF. November $1971.35 \mathrm{pp}$.

Report of an experiment conducted during November 1970 elections in which local candidates on Oahu were offered unlimited free time on area community cable television system; concludes that the television appearances probably played a useful role in the electoral process.

$1410 \mathrm{Yu}$, Arthur Y. C. "A Study of Chinese Organizations in Hawaii with Special Reference to Assimilative Trends." Working Papers no. 3. Honolulu: East-West Culture Learning Institute, $1971.42 \mathrm{pp}$.

Examines assimilative trends in the structures and functions of Chinese organizations in Hawaii; pages 19-20 deal with Chinese-language newspapers.

1411 Tamashiro, John G. "The Japanese in Hawaii and on the Mainland during World War II as Discussed in the Editorial Pages of the Honolulu Advertiser and the Honolulu Star-Bulletin." M.A. Thesis, University of Hawaii, 1972. $218 \mathrm{pp}$.

Compares the editorial positions of the two newspapers, with emphasis on the two questions most often raised: the loyalty of Japanese-Americans and whether individual and minority rights could be preserved in a situation of total war.

1412 "Modern Communication vs. Remoteness." A Research Proposal of the Communication Institute of the East-West Center, Honolulu. April 1974. 10 pp.

A research proposal for a study of the problems of the use of communication to serve isolated populations, using the island of Kauai in the State of Hawaii, as a pilot study. 
1413 Survey and Marketing Services, Inc. Traffic Radio Audit-Coincidental Enumeration In-Traffic and In-Home Radio Audience Survey, Honolulu, Hawaii, Fall 1974. Honolulu. 28 pp.

Report on three-week survey of at-home and in-car radio listeners of Honolulu radio stations.

1414 Barber, Richard J., Donald J. Grace, L. S. Harms, Jim Richstad. Issues in Communication Planning for Hawaii. Honolulu: Hawaii Research Center for Futures Study, 1975. 50 pp.

Focuses on the communication resources necessary to serve communication needs in Hawaii: authors review human needs, communication needs and how these are determined by existing technology or policy. A variety of communication resources and technology as they exist or are planned for Hawaii are reviewed. Communication policy and planning issues are examined. Bibliography.

1415 Survey and Marketing Services, Inc. The Public Radio Study, Part 1: A Study of The Needs and Interests of The Audience for Public Radio Broadcasting in Hawaii, December 1975. 144 pp.

Purpose of this survey report is to provide information to help the Hawaii Public Broadcasting Authority determine community and human needs in Hawaii which the proposed public radio station could meet. Interviewing took place in late 1975.

1416 The Public Radio Study, Part II: A Study of Current Broadcast Programming in Hawaii, and Public Radio's Potential in Comparison with Other Media. $31 \mathrm{pp}$.

This section of the report provides information about educational, cultural, informational, and public service programming by radio and television stations in Hawaii.

1417 The Public Radio Study, Part III: A Survey of Public Television Viewing in Hawaii. $56 \mathrm{pp}$.

Map of geographic areas on Oahu included. Sections contain: Overall results of survey; Characteristics of the Public Television audience; Public TV coverage and reception of survey respondents.

1418 Barber, Richard J. “Who Plans Hawaii's Communication Futures?" Paper prepared for International Conference on Communication Policy and Planning for Development, East-West Communication Institute, Honolulu, April 5-10, 1976. 20 pp. Appendices.

A broad view of Hawaii's history with a focus on its recent communication setting is followed by an overview of many statewide planning efforts. Activities that focus on communication are reviewed, with a brief summary and look into the future. Appendix A: Inventory of recommendations for growth and development, 1961-1974, prepared by Department of Planning and Economic Development, State of Hawaii. Appendix B: Planning issues (A list of 20 specific issues likely to be important to Hawaii.).

\section{EDUCATION AND TRAINING OF COMMUNICATORS}

1419 “"Train More Experts, Says University Head," Editor \& Publisher, 97, no. 37 (September 12, 1964): 12.

The president of the University of Hawaii, in address to the Hawaii Newspaper Publishers Association, recommends the training of more specialists for newspaper writing staffs. 
1420 Carney, Sandra. "Defining the Role of the Journalism Instructor in Hawaii's Community Colleges." Student Paper for Department of American Studies, University of Hawaii, $1973.18 \mathrm{pp}$.

A report on the status of contemporary journalism education in Hawaii; special case study of journalism education at Maui Community College, Kahului, Maui.

1421 "Radio, TV News Training Discussed on PEACESAT," PICN, 4, no. 2 (December 1973): 5-6.

Participants from Hawaii, Fiji, Micronesia, and New Zealand discussed news personnel training on PEACESAT teleconference.

\section{EDUCATIONAL MEDIA \\ Newspapers}

1422 “Hawaii Reading Test Impresses," Editor \& Publisher, 88, no. 50 (December 3,1955): 36.

Territorial Department of Public Instruction reported investigating the possibility of using daily newspapers in school classroom instruction.

1423 "Classroom Program Expanded in Hawaii," Editor \& Publisher, 102, no. 21 (May 24, 1969): 42.

Describes planned summer training course for school teachers in use of newspapers as classroom teaching device; sponsored by Honolulu newspapers.

\section{Radio}

1424 "Radio Funding Turn Down for Now," $A D V$, March 16, 1974, A-9: 1.

State of Hawaii House Consumer Protection Committee has decided not to fund public radio station now.

1425 Armstrong, Dianne. "City Asks Court for New Radio Ruling," $S-B$, November 12, 1974, B-4: 1 .

City filed with State Supreme Court for rehearing on rescinded public radio contract.

1426 Survey and Marketing Services, Inc. The Public Radio Study, Part 1: A Study of The Needs and Interests of The Audience for Public Radio Broadcasting in Hawaii, December 1975. 144 pp.

Purpose of this survey report is to provide information to help the Hawaii Public Broadcasting Authority determine community and human needs in Hawaii which the proposed public radio station could meet. Interviewing took place in late 1975.

1427 The Public Radio Study, Part II: A Study of Current Broadcast Programming in Hawaii, and Public Radio's Potential in Comparison with Other Media. $31 \mathrm{pp}$.

This section of the report provides information about educational, cultural, informational, and public service programming by radio and television stations in Hawaii. The Public Radio Study, Part III: A Survey of Public Television Viewing in Hawaii. $56 \mathrm{pp}$.

Map of geographic areas on Oahu included. Sections contain: Overall results of survey; Characteristics of the Public Television audience; Public TV coverage and reception of survey respondents. 
1429 “" 'Hawaii Public Radio'-A Recommendation for '75," $S-B$, February 22, 1975, A-8: 1.

Statewide public radio recommended to legislature to start late in 1975.

1430 Mayer, Phil. "KHPR, with Something for Everyone," S-B, October 13, 1975, B-4: 1 .

Reviews programming of Hawaii public radio station, scheduled to go into operation in July 1976.

1431 Mann, Bill. "Hawaii Public Broadcasting Director Al Hulsen Gets Things Together for New Station," ADV, October 28, 1975, B-2: 1.

Reviews potential public services that Hawaii's public radio station could offer.

1432 "Witnesses Tune in Favorably to Public Radio," S-B, December 10, 1975, B-10: 1 .

Article reviews letters that were favorable to public radio which were received by the Hawaii State House Committee on Culture and the Arts.

\section{Television}

\section{Documents, Studies, Reports}

1433 Citizenship Hawaii, U.S.A. The Story of Citizenship Hawaii, U.S.A. Honolulu, 1960? 8 pp.

Describes the evolution of an educational television program produced by the group Citizenship Hawaii, U.S.A. to educate youth on American heritage.

1434 KQED. A Plan for Educational Television in Hawaii. Prepared under contract with the U.S. Department of Health, Education, and Welfare. San Francisco, 1961. 72 pp.

1435 Hawaii. Governor's Advisory Committee on Educational Television. "Educational Television for Hawaii: A Report of the Governor's Advisory Committee on Educational Television." Honolulu, November 1, 1962. Paging varies.

Reviews types of programming possible on ETV, potential of ETV in Hawaii public schools, the university, and for public service.

1436 . "Final Report to the Governor's Advisory Committee on Educational Television." Honolulu, September 1, 1964. 23 pp.

Reviews history and status of ETV in Hawaii; recommendations for state educational system, policies, organization and operations.

1437 Hawaii. Department of Education. Office of Instructional Services. "Recommended Origination/Reception Facilities and Operating Budget, Stage 1: Hawaii ETV System." A Supplemental Report. Honolulu, 1964.23 pp.

1438 Honolulu Chamber of Commerce. Education Committee. "Report on Educational Television." Honolulu, 1965.

General information on the principles of educational broadcasting.

1439 Hawaii. Department of Education. Office of Instructional Services. Proceedings of the NDEA Institute on Educational Media at the University of Hawaii, June 20, 1966-July 29, 1966. Eds. Geoffry Z. Kucera and Donald N. Wood. Honolulu, 1966. 293 pp. 
1440 University of Hawaii. Institute on Educational Media. Final Technical Report on the NDEA Institute on Educational Media at the University of Hawaii, June 20, 1966-July 29, 1966. Submitted by Geoffry Z. Kucera, Director. Honolulu, 1966. 116 pp.

1441 Sato, Jessie J. "The Effectiveness of Television and Classroom Instruction in the Teaching of Lines and Designs." Honolulu: University High School, College of Education, University of Hawaii, 1966.9 pp.

1442 Hawaii. Department of Education. Office of Instructional Services. In-School Broadcast Schedule. 1967/68-1971/72.

An annual schedule. "Usage and Utilization of School Television: 1966-67, based upon the ETV School Canvas for Overall Project Evaluation (SCOPE)." Honolulu, 1967. $29 \mathrm{pp}$.

Data on facilities and usage of educational television in Hawaii public schools. Audit of the Hawaii Educational Television System: A Report to the Governor and the Legislature of the State of Hawaii. Draft Audit Report no. 71-74. Honolulu, 1971. $153 \mathrm{pp}$.

Accompanied by a 14-page supplement, "An Overview by the Legislative Auditor of the Audit of the Hawaii Educational Television System."

1445 Office of the Legislative Auditor. Audit of the Hawaii Educational Television System: A Report to the Governor and the Legislature of the State of Hawaii. Draft Audit Report no. 71-74a. Honolulu, 1971. 130 pp.

1446 Tax Foundation of Hawaii. Review Council. "Review Council Report of the Hawaii Educational Television System." Report no. 3. Honolulu, 1971.7 pp.

A study and recommendations regarding the organization, policies, planning, and management of the Hawaii educational television system.

1447 Hwang, John C. "Charting the Interests of the Residents of Oahu: 1971 Pilot Study." Prepared for KHET. Honolulu, January 1972.8 pp.

A survey of 500 households randomly selected from the telephone directory to determine the top twenty activities or hobbies in which Oahu residents are interested as an aid to determining audience interests.

1448 "Suggestions Made by Respondents for the Improvement of Hawaii ETV Network: A Second Periodical Research Report of the 1971-1972 Oahu Audience Survey." Prepared for KHET. Honolulu, March 1972. 61 pp.

Most frequent responses reported in the survey were better promotion of station and programs, wider variety and broader appeal in programs, and removal of reception difficulties.

1449 "The Viewing of Public Television on Oahu." Prepared for the Hawaii ETV Network. Honolulu, May 1972. 166 pp.

Report of a research project to canvass the needs and concerns of the community in programming. 


\section{Journal Articles}

1450 Gordon, Morton J. "Hawaiians Learn Better Speech by TV," NAEB Journal, 21, no. 6 (November-December 1962): 58-61.

Describes the organization and problems associated with a speech improvement course aimed at teaching dialect improvement by television; suggests further uses for television.

1451 Wood, Donald N. "The Development of Educational Television in Hawaii," Pacific Speech, 1, no. 1 (October 1966): 34-38.

Describes the structure of control and responsibility on the state educational television program and outlines transmission and programming plans.

1452 Reed, Robert M. "ETV in Hawaii," Educational Television International, 1, no. 2 (June 1967): 72-81.

Describes the Hawaii education system and the development of educational television in the system; includes data on facilities, staff, and programming.

1453 Wood, Donald N. "Progress in Hawaii," Educational Broadcasting Review, 2, no. 4 (August 1968): 46-50.

Progress report on Hawaii's educational television system after two years of operation; discusses organization of the school system, ETV operations and facilities, and ETV usage.

1454 "Trial and Ordeal of an ETV Sex Series in Hawaii," Educational

Television, 1, no. 9 (July 1969): 14-16.

Describes the public controversy, including an unsuccessful attempt to obtain a court injunction, surrounding the broadcast over the Hawaii educational television system of the sex-education series "A Time of Your Life" in 1969.

\section{Newspaper and Magazine Articles}

1455 "Educational Use of TV Will be Surveyed Here," $A D V$, April 26, 1953, II-6: 7.

Conference called by Hawaii's Gov. Samuel King to discuss costs and other factors necessary to start ETV on Channel 7.

1456 "Educational TV Backed by Professor," $A D V$, May 20, 1953, 7: 3.

Joseph Smith, Head of University of Hawaii's Speech Department, stressed need for ETV in Hawaii's "educational crisis."

1457 "Educational TV Gets Backing of Parley," $A D V$, May 23, 1953, 1: 7.

Discusses Hawaii ETV conference.

1458 "Report Urging Adoption of TV Education Readied," $A D V$, May 27, 1953, II-1: 6 .

Continued discussion of ETV conference and findings.

1459 "First Educational TV Survey Completed by Community TV Council," $S-B$, June 8, 1953, 2: 2.

Survey of current TV programming complete; only KGMB-TV "doing a good job of programming for children."

1460 "Oahu School Teachers Make TV Educational Worth Survey," $S-B$, December 12, 1953, 22: 3.

Hawaii Educational Association study being conducted by school teachers will evaluate 32 programs shown on the two Honolulu TV stations. 
1461 “Joint Radio-TV Setup Studied by Broadcasters," $A D V$, January 8, 1954, A-5: 1 .

Review of Broadcast Music, Inc., holding a "clinic" on radio and TV problems.

1462 “32 Named to Educational TV Council,” $A D V$, January 21, 1954, A-6: 5.

Announcement of members of Territorial Council on Educational Television.

1463 "Survey Rates Hawaii TV High in Educational Value," $S$ - $B$, February 8, 1954, 14: 2 .

Reviews the ratings of 31 programs viewed on KGMB-TV and KONA-TV in a survey by Hawaii Educational Association.

1464 "Waipahu Survey Shows TV Affects School Child's School Work," S-B, November 26, 1954, 16: 3.

Survey of 660 students at August Ahrens School in Waipahu, Hawaii, revealed that $2 / 3$ of the children's families had TV sets; that $86 \%$ of students watch TV at home or at a friend's home; the average TV-viewing time was 3 hours daily; that 5 th and 6 th graders watched slightly more TV than other grade students did.

1465 "Sinclair Cites Television Help to Education," S-B, December 1, 1954, 34: 4.

President Gregg Sinclair of University of Hawaii said TV may be an educational tool for colleges if there are not enough college teachers in future.

1466 "Television \& The Schools," $A D V$, May 28, 1956, A-4: 1.

Editorial reviews a national project to study ETV as an aid to teachers.

1467 Burk, Gay. "Parents Disagree on Effects of TV But Teachers See Educational Use," $S$ - $B$, July 16, 1958, 22: 1.

Reports informal poll of parents and teachers on effects of TV.

1468 Jones, Kathleen. "Do Children Look at Too Much TV?" ADV, July 9, 1961, D-1: 1.

Reviews report by Wilbur Schramm, Jack Lyle, and Edwin B. Parker on effects of TV on children; reports interviews with parents on subject.

1469 "Local Authorities Give Opinions," $A D V$, July 9, 1961, D-1: 1.

Discussion of the effects of TV on children by professionals.

1470 “Big Isle ETV to Transmit by June 1," $S$ - $B$, May 20, 1968, D-1: 4.

Short announcement.

1471 “'Big Isle Viewers Get Weaker ETV Signal," $S-B$, July 19, 1968, C-5: 2.

Reviews TV reception problems at Educational TV station; KHET-TV will ask FCC to allow power boost.

1472 “Color Seen for Hawaii's ETV," $A D V$, February 19, 1969, E-5: 4.

Reviews probable changeover to color programming by KHET-TV.

1473 Evinger, Jane. "ETV Expert Cites Hawaii Potential," ADV, August 2, 1969, A-6: 4.

Lyle Nelson of Stanford University, Department of Communication, reviews his study of Hawaii's ETV system. 
1474 “'Representative Matsunaga Urges No Cut in ETV Funds," $S$ - $B$, January 13, 1971, F-8: 5.

Reports letter Representative Spark Matsunaga has written to Health, Education, and Welfare Secretary concerning fears that ETV funds might be cut.

1475 “'Spark Gains Funds for ETV," $A D V$, January 21, 1971, D-22: 2.

In response to a request from Representative Spark Matsunaga not to cut ETV funds, the Secretary of Health, Education, and Welfare has determined that there will be no cut in funding.

1476 “ETV Survey Gives Few Answers,” $S$ - $B$, January 31, 1972, D-4: 1.

Water sports rank at top of ETV audience interest survey.

1477 “'Public Broadcasting Foundation Urged,"' $A D V$, April 12, 1972, A-17: 2.

K. S. Sitaram commentary criticizing ETV and ITV (instructional TV), including an audience survey of Hawaii Educational Television Network and suggestions for a Hawaii Public Broadcasting Foundation.

1478 “'KHET-TV Gains New Management,”' $A D V$, June 30, 1973, C-1: 1.

Hawaii's Public Broadcasting Authority assumes control of Hawaii's ETV on July 1, replacing the University of Hawaii and the State Department of Education.

1479 “'TV Director Nominated,"' $S$ - B, November 9, 1974, B-16: 7.

Mary Bitterman will assume directorship of KHET-TV.

1480 “ETV Relay on Kauai Approved," $S-B$, March 12, 1975, A-3: 1.

FCC approves relay station near Kalaheo.

\section{FREEDOM OF THE PRESS/BROADCASTING}

1481 “'Press Control in Hawaiian Islands,'” Editor \& Publisher, June 4, 1921, p. 12.

Describes attempts to control allegedly seditious material in foreign-language newspapers.

1482 "Newspaper, Radio Censorship Set Up: Territory of Hawaii, Office of the Military Governor, Fort Shafter, December 10, 1941,' $A D V$, December 12, 1941, 6: 4; $S$ - $B$, December $12,1941,1$.

General Orders no. 14 from the United States Military Governor in Territory of Hawaii, gave list of the newspapers, radio stations, and one press association which could operate under military orders, from December 12, 1941 .

1483 “Trials of War Change Your Daily Newspaper," $A D V$, March 29, 1942, 1: 3.

Describes effects of wartime conditions on production of newspapers in Hawaii; includes discussion of censorship procedures.

1484 Lind, Andrew W. Japanese in Hawaii Under War Conditions. Honolulu: Institute of Pacific Relations, 1943. 41 pp.

Includes discussion of restrictions on Japanese-language newspapers and radio broadcasts during World War II.

1485 Allen, Riley. "Memorandum on Newspaper Censorship in Hawaii," June 5, 1944, Hawaii War Records Depository, University of Hawaii, Honolulu.

Describes censorship by editor of Honolulu Star-Bulletin.

1486 “'Mail, Wireless Order Censorships End Here," $S$ - $B$, August 15, 1945, 1: 4.

Announces civilian censorship finished due to cease fire; service personnel and press agencies still under restrictions. 
1487 Allen, Gwenfread. Hawaii's War Years, 1941-1945. Honolulu: University of Hawaii Press, 1950. 418 pp.

Includes information on use of mass media during war conditions.

1488 Allen, Gwenfread, et al. Notes and References to Hawaii's War Years, 1941-1945, with a Complete Bibliography. Rev. \& ed. by Aldyth V. Morris. Honolulu: University of Hawaii Press, 1952. Paging varies.

Contains bibliography of radio broadcasts and news media accounts concerning World War II.

1489 Anthony, J. Garner. Hawaii Under Army Rule. Stanford: Stanford University Press, 1955. Report, Honolulu: University Press of Hawaii, 1975. 203 pp.

A critical examination of the legal aspects of martial law in Hawaii during World War II; the author served as attorney general of Hawaii for part of the period. See especially pages $39-41$ on press censorship.

1490 Richstad, Jim A. "The Press and the Courts Under Martial Rule in Hawaii During World War II-From Pearl Harbor to Duncan v. Kahanamoku." Ph.D. dissertation, University of Minnesota, 1967. $420 \mathrm{pp}$.

An account of military control of the press and radio in Hawaii during World War II; covers the military governor's regulations on the press, press response to controls, the lifting of controls, and related court actions concerning the authority of the military.

1491 Pratte, Alf. "Wartime Censors 'Guided' Isle Press," S-B, March 17, 1967, C-2: 1 .

Article (in series of four articles) reviews World War II censorship of phone calls, cables, press, radio.

1492 "Editor to Mayor: Debate in Print, Not on Television," S-B, July 3, 1969, A-16: 1 .

Editors of Honolulu's two major dailies were challenged to TV debate on freedom of the press by Mayor Frank Fasi.

1493 “ 'Can't Fight City Hall!'-It's Not So in Honolulu," Editor \& Publisher, 102, no. 47 (November 22, 1969): 18.

Described the strained relations between the mayor of Honolulu and the Honolulu newspapers, including his ban on reporters of the Star-Bulletin.

1494 Richstad, Jim A. The Press Under Martial Law: The Hawaiian Experience. Journalism Monographs no. 17. Lexington, Ky.: Association for Education in Journalism, $1970.41 \mathrm{pp}$.

An examination of the press under military control in Hawaii during World War II drawn from the author's doctoral dissertation; discusses press controls, relevant legal cases, effects on the press, and implications for the future.

1495 "Casey Calls for Freedom of Press," $S-B$, February 10, 1970, A-8: 1.

Resolution prepared for submission by Councilman Brian Casey calls for the City Council to go on record "as strongly reaffirming its deep faith in the freedom of the press and free flow of information."

\section{6 "'Editor Backs Measures for News Access," S-B, March 6, 1970, A-2: 3.}

Article reviews comments made by Hobert Duncan, Managing Editor of Star-Bulletin, to the State Senate Judiciary Committee about right of news media to question public officials. 
1497 “Editor Says Press Ban is Censorship,” $S-B$, March 7, 1970, A-7: 1.

Comments of Hobert Duncan, Managing Editor of Star-Bulletin, who said that a public official who bans press representatives is indulging in news censorship.

1498 “Approval Urged of News Source Protection Bill,” S-B, March 20, 1970, A-3: 1 .

Article reviews comments of Hobert Duncan, Managing Editor of the Star-Bulletin, concerning his support of the news source protection bill.

1499 “'Editor Stresses Bill's Importance,” $S$ - B, April 1, 1970, E-8: 1.

Article reports statements of Hobert E. Duncan, Managing Editor of Star-Bulletin, supporting legislative bill that would give legal protection to news sources.

1500 Lynch, Russ. “Protecting Newsmen's Sources," Hawaii Journalism Review, 1, no. 1 (February 1971), not paged.

Urges enactment of a shield law.

1501 “Anderson Proposes Press Law," $A D V$, February 23, 1971, A-8: 1.

Senator D. G. "Andy" Anderson introduced bill to prohibit any state or county official from barring newsmen from press conferences.

1502 Wernet, Bob. “With the Law on Our Side," Hawaii Journalism Review, 1, no. 4 (July 1971), not paged.

Describes an incident in which reporters forced the opening of a Honolulu City Council meeting being held behind closed doors.

1503 Kashiwahara, Ken. “Keep It Quiet,'” Hawaii Journalism Review, 1, no. 5 (August 1971), not paged.

Criticizes the Honolulu Police Commission for handling information about a gun-smuggling incident at the county jail in a manner constituting censorship.

1504 Tenbruggencate, Jan. “' 'Right' to Broadcast Hearings Disputed on Kauai," $S B A$, October 3, 1971, A-14: 1.

Review of KUAI being refused permission to broadcast state regulatory agency hearing.

1505 Jones, Bob. “Censorship by the Police," Hawaii Journalism Review, 2, no. 1 (January 1972), not paged.

Reviews case of police attempting to censor part of news story on the recapture of persons who got away from police custody.

1506 Donham, Buck. "TV-4 Squelched by Legal Fears," Hawaii Journalism Review, 2, no. 4 (April 1972), not paged.

Using the example of a local television station's reluctance to broadcast a story it had first, the writer urges television broadcasters to seek First Amendment protection.

1507 Burris, Jerry. "UH Regents Set Example for Secrecy," Hawaii Journalism Review, 2, no. 7 (November 1972), not paged.

Criticizes the University of Hawaii Board of Regents for keeping deliberations secret from press.

1508 Sullam, Brian. "Mayor Fasi Meets the Press," Hawaii Observer, no. 21 (November 27, 1973): 3.

Discusses dispute between the Honolulu Star-Bulletin and the mayor of Honolulu in which a reporter was barred from the mayor's news conferences; criticizes the newspaper for failing to take more vigorous action. 
1509 “Honolulu Mayor Fights with Papers Over Access,” Editor \& Publisher, 107, no. 3 (January 19, 1974): 10.

Mayor of Honolulu bans newspaper reporters from his news conferences; newspapers seek relief in court.

\section{0 "Editor's Objection Upheld," $A D V$, February 1, 1974, A-10: 2.}

Committee of Honolulu Community Media Council upheld complaint from Advertiser executive against advertisement titled "Good Guys for Fasi" which appeared in Advertiser.

1511 "Barred Reporters Allowed Back by Honolulu Mayor," Editor \& Publisher, 107, no. 5 (February 2, 1974): 13.

Reports decision of mayor of Honolulu to end ban on presence of newspaper reporters at news conferences; newspapers seek court injunction.

1512 Newport, Tuck. "Fasi and the Newspapers," Hawaii Observer, no. 25 (February 5, 1974): 3 .

A commentary on the relationship between the mayor of Honolulu and the press.

1513 "Mayor Fasi Routs the Star-Bulletin," Hawaii Observer, no. 26 (February 19, 1974): 6.

Describes the resolution of a dispute in which the mayor of Honolulu excluded newspaper reporters from his news conferences.

\section{4 “McClung Accuses Star-Bulletin," S-B, March 4, 1974, A-5: 1.}

Senate President David C. McClung introduced Senate resolution charging Star-Bulletin with "obstructing the right of the public to have reasonable access to the news." Reasons given included: Star-Bulletin raised street price of paper, abandoned the three-star edition, and ceased home deliveries on neighboring islands.

1515 "'Honolulu Mayor Attempts to Put Papers Under PUC," Editor \& Publisher, 107, no. 15 (April 13, 1974): 16.

Discusses opinion of Hawaii Attorney General's office that a bill making Honolulu's major daily newspapers subject to the state Public Utilities Commission would be unconstitutional.

1516 “Should Press Conference Be Open to All?" PICN, 4, no. 3 (May 1974): 3.

Reviews the exclusion of newspaper reporters from news conferences by the mayor of Honolulu.

1517 “Federal Judge Upholds Press Access Rights," Editor \& Publisher, 107, no. 25 (June 22, 1974): 12.

Describes judgment and agreement entered in federal court finding that the mayor of Honolulu violated the U.S. Constitution in banning newspaper reporters from news conferences.

1518 "New Hawaii Law Lets Police Withhold Arrest Information," Editor \& Publisher, 107, no. 25 (June 22, 1974): 12.

Reports police withholding of arrest information under a new state law; temporary restraining order issued by a federal judge; opposition of news media described.

1519 “Judge Grants News Media Access to Police Files,” Editor \& Publisher, 107, no. 26 (June 29, 1974): 12.

Reports the granting of a preliminary injunction against a state law allowing police to restrict information available to news media.

1520 Sullam, Brian. "An Account of Fasi's Relations with the Press," Hawaii Observer, no. 39 (September 10, 1974): 6-8; no. 40 (September 24, 1974): 6-8.

A detailed account of the troubled relations between the mayor of Honolulu and the press. 
1521 "Hawaii Senate Considers Bill for Media Control," Editor \& Publisher, 108, no. 6 (February 8, 1975): 28.

Article reviews Hawaii State Senate bill calling for the establishment of a media responsibility commission that would oversee complaints against local newspapers, TV and radio stations.

1522 “Right to Communicate," PICN, 6, no. 1 (March 1976): 12.

Article describes a series of community dialogues on the Right to Communicate that took place in March on several Hawaii islands. Main concern of dialogues was determining "grass roots" issues from each island.

1523 "Policy Dialog on the Right of Everyone in Hawaii to Communicate," eds. L. S. Harms, Jim Richstad, Bruce Barnes, Kathleen A. Kie, in Communication in Hawaii Series, no. 2. Honolulu: University of Hawaii, June 1976.68 pp.

Report on series of community discussions on right to communicate on Islands of Kauai, Maui, Hawaii and Oahu, examining particular communication rights concerns on each island.

\section{LABOR RELATIONS}

1524 "Newspapermen Form Guild at NRA Suggestion," $A D V$, February 3, 1934, 3: 1 .

Reports organization of the Hawaii Newspaper Guild for the purpose of improving working conditions, raising standards of journalism, and expressing the collective sentiment of its members.

1525 “Nippu Jiji Held Unable to Meet Wage Demands," ADV, March 10, 1940, 4:

2.

Reports testimony at National Labor Relations Board hearing on charges of unfair labor practices against Nippu Jiji; the newspaper's city editor contends that the paper could not meet the wage demands of the Honolulu Typographical Union.

1526 “Dismissal of Nippu Jiji Case is Recommended," $S$-B, July 5, 1940, 2: 6.

Reports a National Labor Relations Board trial examiner's recommendation that charges against Nip$p u$ Jiji be dropped; newspaper had been accused of interfering with employee rights, discouraging union membership, and refusing to engage in collective bargaining.

1527 “AFL-CIO Admits Isle Newspaper Guild,” $A D V$, February 22, 1956, B-7: 4.

Reports acceptance of Hawaii Newspaper Guild as member of the American Newspaper Guild, AFLCIO.

1528 “'Boost Printers' Pay,” Editor \& Publisher, 89, no. 36 (September 1, 1956): 20.

Short item reporting agreement on a new two-year contract between the Maui Publishing Company and the International Typographical Union; outlines pay provisions.

1529 "Pay Hike in Hawaii," Editor \& Publisher, 89, no. 36 (September 1, 1956): 40 .

Short item reporting ratification of a new two-year contract for editorial employees of Honolulu Advertiser; outlines pay provisions.

1530 “ANG Relents In Honolulu 2-Year Pact," Editor \& Publisher, 89, no. 40 (September 29, 1956): 30.

Reports the conclusion of a contract between the Honolulu Star-Bulletin and the Hawaii Newspaper Guild; outlines contract provisions. 
1531 “' 'Front Office' Guild,” Editor \& Publisher, 89, no. 50 (December 8, 1956): 47.

Short item reporting results of an election in which the American Newspaper Guild won the right to represent 61 office workers at the Honolulu Star-Bulletin.

1532 “Vote for Guild," Editor \& Publisher, 90, no. 29 (July 13, 1957): 6.

Short item reporting Hawaii Newspaper Guild winning right to represent 128 employees of the Honolulu Advertiser commercial, circulation, and maintenance departments.

1533 “"Ruling Against Paper," Editor \& Publisher, 90, no. 36 (August 31, 1957): 58.

Reports a National Labor Relations Board trial examiner's recommendation that the Honolulu StarBulletin be held in violation of the Taft-Hartley Act for discharging two printers.

1534 "'Strike-Reasons and Facts of the Hawaii Press Newspapers Strike," $A D V$, May 2, 1963, C-12: 6.

A union advertisement listing 37 reasons for its strike against the Hawaii Press Newspapers.

1535 “Weekly Newspaper Strike Goes On: No Break in Sight," $A D V$, May 3, 1963, C-1: 6 .

Status report on strike against Hawaii Press Newspapers.

1536 “' “Tiser, S-B Employees Are Told of Offers,'” $S B A$, June 16, 1963, 1: 1.

Consists primarily of a letter from the publisher of the Honolulu Advertiser, Thurston Twigg-Smith, to employees urging serious consideration of a management offer.

1537 “Mediators Enter News Dispute," $S-B$, June 17, 1963, 1: 2.

Reports entry of federal mediators into negotiations between Honolulu Advertiser and Honolulu StarBulletin and six labor unions.

1538 "Newspaper Walkout Here Postponed for 24 Hours," $A D V$, June 18, 1963, A-1: 6.

Reports delay in planned strike against Honolulu Advertiser and Honolulu Star-Bulletin.

1539 “Mediators Fly in for News Talks," $A D V$, June 19, 1963, 1: 1.

Reports arrival of federal labor mediators to attempt to break deadlock in talks between Honolulu Advertiser and Honolulu Star-Bulletin and labor unions representing their employees.

1540 “'Two Isle Dailies Struck,”' Hawaii Times, June 21, 1963, 1: 1.

Reports start of strike against Honolulu Advertiser and Honolulu Star-Bulletin after the failure of mediation efforts.

1541 "Isle Newspaper Strike in Second Day; No Talks," Hawaii Times, June 22, 1963, 1: 5 .

1542 “Tries to Get News Strike Talks Fail," Hawaii Times, June 25, 1963, 1: 4.

Reports unsuccessful attempts by the governor of Hawaii and federal mediators to promote settlement of strike at Honolulu Advertiser and Honolulu Star-Bulletin.

1543 “News Strike Talks Broke Off Today,” Hawaii Times, June 29, 1963, 1: 1.

Reports interruption of mediation between Honolulu Advertiser and Honolulu Star-Bulletin and six unions. 
1544 "7 Unions Strike, Close Down Honolulu's 2 Major Dailies," Editor \& Publisher, 96, no. 26 (June 29, 1963): 9.

Discusses strike against Honolulu Advertiser and Honolulu Star-Bulletin and issues involved.

1545 “No End Seen in Newspaper Strike Here," Hawaii Times, July 3, 1963, 1: 2. Strike report on Honolulu Advertiser and Honolulu Star-Bulletin.

1546 “Face-to-Face News Strike Meet Slated," Hawaii Times, July 10, 1963, 1: 4.

Reports meeting of representatives of the Honolulu Advertiser and Honolulu Star-Bulletin with a federal mediator.

1547 "No Apparent Hope for Early News Strike End," Hawaii Times, July 16, 1963, 1: 4.

Discusses strike at Advertiser and Star-Bulletin.

1548 “Unions Reject New Offer, Honolulu Strike Still On," Editor \& Publisher, 96, no. 30 (July 27,1963 ): 14.

Describes strike settlement offer by Honolulu Advertiser and Honolulu Star-Bulletin and its rejection; discusses expansion of other newspapers during strike.

1549 "'Minor Issue Blocks News Settlement," Hawaii Times, August 2, 1963, 1: 6.

Reports end near in strike at the Advertiser and the Star-Bulletin.

1550 “Major Dailies Resume Printing Tomorrow Morn," Hawaii Times, August 6, 1963, 1: 3 .

Reports ratification of contracts ending strike at Honolulu Advertiser and Honolulu Star-Bulletin.

1551 “Aloha Dere! It's Sure Great to be Back," $A D V$, August 7, 1963, A-1: 1.

Discusses end of newspaper strike and final six days of the strike.

1552 "'Unions Threaten Boycott of Fern,"' $A D V$, August 8, 1963, B-3: 5.

Reports union threat to boycott firms advertising in papers that are operating during a strike at Hawaii Press Newspapers.

1553 "2 Major Honolulu Dailies Resume After 44-Day Strike," Editor \& Publisher, 96, no. 32 (August 10, 1963): 11.

Describes settlement of strike against Honolulu Advertiser and Honolulu Star-Bulletin; recounts conduct of strike and negotiations.

1554 Leab, Daniel J. "Strike-With Ukuleles," Columbia Journalism Review, 2, no. 3 (Fall 1963): 36-37.

Describes strike at Honolulu Advertiser and Honolulu Star-Bulletin.

1555 “Printers Reject Newspaper Offer," S-B, July 18, 1966, C-4: 1.

Reports rejection of proposed contract terms by International Typographical Union.

1556 Dunlap, Sky. "Group Told Labor Getting 'Tough to Buck'," Editor \& Publisher, 99, no. 40 (October 1, 1966): 24.

A report on the main address, on labor-management relations, at Hawaii Newspaper Publishers Association meeting; summarizes other program events.

1557 “'Hilo Guild Joins Strike at Tribune," $A D V$, May 26, 1967, A-4: 1.

Reports Hawaii Newspaper Guild joins strike at Hawaii Tribune-Herald in Hilo. 
1558 “Newspapers, Unions Settle Dispute Here," $S B A$, January 12, 1969, A-1: 1; $A D V$, January 13, 1969, D-1: 1 .

Reports end of two-and-one-half-day boycott against Associated Press.

1559 “'Hawaii Contract Gives \$48 Raise,” Editor \& Publisher, 102, no. 14 (April 5, 1969): 22.

Describes provisions of contract negotiated by the Hawaii Newspaper Guild, Honolulu Star-Bulletin and Honolulu Advertiser.

1560 “Newspaper Employees Win Industry-High Contract," PICN, 4, no. 3 (May 1974): 9.

Gives details of contract negotiated at Honolulu Advertiser and Honolulu Star-Bulletin.

\section{LEGAL ISSUES}

1561 "Judge Rules Advertiser Has Cause for Action," S-B, October 26, 1949, 12: 1 .

Reports court refusal to dismiss a libel suit brought by the Advertiser Publishing Company against the International Longshoremen's and Warehousemen's Union, Robert L. McElrath, and radio station KHON for allegedly defamatory statements made by McElrath on a union-sponsored radio program.

1562 “9-Year-Old Hawaiian Libel Suit Dismissed,” Editor \& Publisher, 83, no. 50 (December 9, 1950): 24.

Reports the dismissal due to legal inaction of a libel suit brought by A. M. Cabrinha, owner and publisher of the Hawaii News, against the Hilo Tribune-Herald.

1563 “'Dieters Plan to Name Isle Paper in Suit,” $A D V$, October 12, 1956, A-1: 4.

Reports threats by five members of the Japanese Diet to sue the Hawaii Times for libel in connection with a story accusing the Japanese of unbecoming conduct during a visit to Hawaii.

1564 “Advertiser Wins Suit to Recover T.H. Taxes," $A D V$, October 31, 1956, B-1: 4.

Reports court decision allowing Advertiser to recover $\$ 30,892$ in taxes for 1952 and 1953 ; court ruled the paper should have been taxed as a manufacturer rather than at the higher rate applied to service businesses.

1565 “Manufacture Rate Applied to Ad Tax," Editor \& Publisher, 89, no. 46 (November 10, 1956): 26.

Reports a court decision entitling the Honolulu Advertiser to recover $\$ 90,000$ in taxes; court ruled the paper should be taxed as a manufacturer rather than at the higher rate applied to service enterprises.

1566 “Planners Probe Libel in Editorial,” $A D V$, June 14, 1957, C-1: 6.

Reports request of Honolulu Planning Commissioners that city attorneys investigate possibility of a libel suit in connection with an editorial in the Windward Oahu Reporter criticizing a Commission zoning action.

1567 "Grievances Against T. Twigg-Smith and D. Twigg-Smith Detailed in Complaint Filed by L. P. Thurston," $S$ - B, June 9, 1962, 2: 5.

Discusses Thurston's allegations of misconduct as officers of Honolulu Advertiser.

1568 “'Twigg-Smith Says 'Tiser Faced Ruin,” $A D V$, June 13, 1962, B-1: 3.

Detailed account of court hearings on dispute between L. P. Thurston and Thurston Twigg-Smith, publisher of Honolulu Advertiser. 
1569 “Thurston Asks $\$ 250,000$ in New Court Complaint," $A D V$, December 21 , 1962, A-11: 1 .

Reports filing of complaint against Thurston Twigg-Smith of the Honolulu Advertiser.

1570 "Adm. Drops Suit Against Chaplin and Advertiser," Hawaii Times, July 10, 1963, 1: 5 .

Reports settlement of suit brought by retired naval officer against the Honolulu Advertiser, alleging the newspaper falsely implied he advocated a surprise attack on the Soviet Union.

1571 “' 'Tiser Wins House Suit; Court Rebukes Thurston,” $A D V$, September 5, 1963, A-1: 6.

Details attempts of Honolulu Advertiser to regain control over a house claimed by L. P. Thurston.

1572 "Judge Dismisses Thurston Suit Against Advertiser," $A D V$, May 21, 1964, B-1: 6.

Reports dismissal of suit brought by L. P. Thurston two years earlier.

1573 “'Hawaii Papers Fight Ban on Street Racks," Editor \& Publisher, 97, no. 52 (December 26, 1964): 39.

Describes attempts of a Honolulu councilman to have newspaper vending racks banned from streets; includes opposing statements by publisher of Honolulu Star-Bulletin.

1574 “'Legal Ads Ruled Legal in English-Japanese Paper," $S$-B, July 29, 1965, AA: 4 .

Reports court ruling that Hawaii Times qualifies as a newspaper of general circulation and can be used for publication of legal notices.

1575 “KTRG-TV Is Sued by Mainland Firm,’ $S$ - $B$, May 4, 1967, A-11: 1.

Reports filing of suit by Friendly Broadcasting Co. against Hawaiian Paradise Park Corp.; suit claims station's president, David Watumull, had made contract to sell the station.

1576 “"TV Station Owners Reneged, Suit Says," $A D V$, May 4, 1967, A-19: 3.

Reports suit brought by Friendly Broadcasting Co. against Hawaiian Paradise Park Corp., owner of KTRG-TV; suit claims the station owner failed to honor a contract for sale of the station to Friendly Broadcasting.

1577 “KTRG-TV Sale Binding, Judge Tavares Rules,” $S$ - B, June 20, 1967, B-8: 1.

Reports federal court ruling in support of Friendly Broadcasting $\mathrm{Co}$. claim that a binding contract had been made for sale of KTRG-TV by Hawaiian Paradise Park Corp.

1578 “" 'Failing Newspaper Bill' in Senate,” $A D V$, February 10, 1971, A-6: 8.

Bill introduced in Senate which would bring Hawaii into conformity with national public policy on antitrust issue which authorizes competing newspapers to merge their noneditorial functions so long as the newspapers maintain independent editorial staffs and policies.

1579 “State Newspaper Law Termed Unnecessary," $S-B$, March 5, 1971, A-15: 1.

State Attorney General's Office called State Newspaper Law a duplication of the Federal Newspaper Preservation Act.

1580 “'State Newspaper Bill Commended," $A D V$, March 10, 1971, A-10: 1.

Advertiser Editor George Chaplin said State Senate passage of the Newspaper Preservation Bill shows "enlightened awareness of the need to insure independent editorial voices in Hawaii." 
1581 Donham, Buck. "House Hears Testimony on State Newspaper Bill," $S-B$, April 9, 1971, A-12: 1.

Article reviews pro and con statements concerning State Newspaper Bill being considered by the House Judiciary Committee.

1582 “'It's All on the Books," Hawaii Journalism Review, 1, no. 4 (July 1971), not paged.

Reports judgment against the Kona Times in a libel suit brought by a university student.

1583 “'Suit Against Advertiser Dismissed by Judge," ADV, March 1, 1973, A-12: 1.

Reports suit by two Seattle men who charged that $A d v e r t i s e r$ had libeled them in Mafia news stories in 1971 has been dropped.

1584 Adamski, Mary. "Court Issues Order Restraining Publication," $S$ - $B$, August 4, 1973, A-1: 1, A-4: 7.

Reviews court action halting Star-Bulletin publication of interviews with underworld informer.

1585 “'Publisher Comments on Court's Action," S-B, August 4, 1973, A-1: 6.

Publisher questions constitutionality of court's restraining order on exposé series.

1586 Toner, Tim. “Judge Lifts Order Restraining Series,” $A D V$, August 8, 1973, A-4: 1 .

Reports restraining order prohibiting Star-Bulletin from printing series on life of an underworld informer was lifted; argument about "freedom of the press" and the "right to a fair trial" reviewed.

1587 “Paper Sues Fasi for Barring Reporter," $A D V$, December 22, 1973, A-10: 1.

Star-Bulletin files legal suit against Mayor Frank Fasi alleging that the mayor witheld information illegally from their political reporter.

1588 “Plea Asks to Protect Newsmen,” $A D V$, January 3, 1974, A-5: 1.

Star-Bulletin files motion in Federal Court that it not be required to reveal names of reporters writing stories about crime-syndicate members.

1589 Toner, Tim. “King Will Decide Monday on News Conference Access," $A D V$, January 5, 1974, A-8: 1.

Article continues the story about Mayor Frank Fasi and Star-Bulletin reporter, Richard Borreca, excluded from the mayor's press conferences.

1590 Carlson, Douglas. "Fasi Blocked-for Now-from Keeping Out Reporter," $A D V$, January 8, 1974, A-1: 2; S-B, January 8, 1974, A-1: 2.

Federal Judge Samuel $\mathrm{P}$. King granted preliminary injunction against the mayor to allow the StarBulletin's reporter to now attend news conferences; Fasi plans appeal.

1591 Burris, Jerry. "Fasi Will Exclude Both Major Dailies," $A D V$, January 9, 1974, A-1: 1 .

Mayor Frank Fasi holds meeting with "electronic Media" (radio and television) to announce he wouldn't talk to the major dailies' reporters because he feels the Advertiser and Star-Bulletin were acting as a monopoly; action in defiance of Federal judge's preliminary ruling against the mayor.

1592 “Advertiser Asks Equal Access: Suit on City Hall," $A D V$, January 11, 1974, A-1: 4.

Advertiser seeks court order to obtain access to Honolulu Mayor Frank Fasi's press conferences. 
1593 “Fasi Submits Conditions,”' $A D V$, January 11, 1974, A-1: 5, A-6: 1.

Letter from Mayor Frank Fasi to Advertiser Editor-in-Chief George Chaplin asks newspapers to give him equal space to present his view of news reports.

1594 “Fasi Asks for Press Space,” $S$ - B, January 15, 1974, A-16: 1.

Mayor Frank Fasi asks that Star-Bulletin allow him the right to reply in print to any news story or editorial with which he disagreed in exchange for allowing Star-Bulletin reporters to attend his press conferences; this "right to reply" would extend to all public figures.

1595 Carlson, Douglas. "Star-Bulletin Drops Fasi Suit," $A D V$, January 23, 1974, A-11: 1 .

Star-Bulletin drops suit against Mayor Frank Fasi and will not seek a permanent injunction requiring the mayor to admit a reporter to his press conferences.

1596 “Fasi Says Advertiser Suit Moot," $A D V$, February 8, 1974, A-5: 1.

Mayor Frank Fasi said newspaper reporters had been invited back so federal suit now unimportant; Advertiser seeking permanent injunction against further press exclusion from press conferences.

1597 "'Fasi and His Objectives,"' $A D V$, February 28, 1974, A-10: 1.

Editorial in Advertiser on Mayor Frank Fasi's motives in dispute with press.

1598 "Fasi Urges Repeal of Newspaper Act," $A D V$, February 28, 1974, A-9: 1.

Mayor Frank Fasi wants Public Utilities Commission (PUC) control of Hawaii Newspaper Agency, which handles the non-editorial functions of the Advertiser and the Star-Bulletin, or the repeal of Hawaii's Newspaper Preservation Act.

1599 “'Paper Control Bill Introduced in House,” $A D V$, February 28, 1974, A-9: 3.

Mayor Frank Fasi urges bill to put Advertiser and Star-Bulletin under Public Utilities Commission control because he feels the two major dailies have a State of Hawaii-sanctioned joint operating agreement.

1600 Gee, Harriet. "Ruling on Newspaper Rights Ready for Judge's Signature," $S-B$, June 11, 1974, A-2: 4.

Federal Judge Martin Pence expected to sign declaratory judgment saying Mayor Frank Fasi violated Advertiser's constitutional rights when he excluded its reporter from a press conference.

\section{NEWS AGENCIES}

1601 “News Service Will Cover the Pacific,"' $S$ - $B$, September 8, 1970, A-2: 5.

Announcement that Guam Publishers, Inc., a subsidiary corporation of the Star-Bulletin, will start the Pacific Daily News Service, with headquarters in Honolulu; aim will be to present stories of Pacific Basin in depth.

1602 “Cable News Report Debuts in Hawaii," PICN, 5, no. 4 (December 1975): 6. UPI news report for cable television via satellite debuts in Hawaii July 21, 1975.

\section{THE PRESS \\ General}

1603 “'History of English Newspapers in the Pacific," The Friend, January 1850, p. 4.

List of English-language newspapers established after the first publication of The Friend; includes newspapers on the west coast of North and South America and in Polynesia. 
1604 Sheldon, H. L. "Historical Sketch of the Press of Honolulu," Thrum's Hawaiian Annual, 2 (1876): 40-44.

Brief history of English-language newspapers in Honolulu.

1605 Whitney, H. M. "Newspapers of Hawaii: How the People Get the Daily Doings of the City,' Hawaiian Gazette, May 1, 1894, p. 1.

Reviews the four English-language dailies and some of the weeklies and monthlies of that time.

1606 “'Hawaiian Periodicals Published in Several Languages," Hawaiian Historical Society Report, 1902, pp. 32-37.

Alphabetical list of 140 periodicals published in Hawaii.

1607 Carter, J. O. "Reminiscences of Early Journalism," Pacific Commercial Advertiser, 50th Anniversary Edition, July 2, 1906, pp. 15-16.

1608 “Polyglot Papers,” Editor \& Publisher, 11 (September 30, 1911): 12.

1609 “Newspapers of Hawaii,” Editor \& Publisher, 53 (January 22, 1921): 110.

1610 Case, Howard D. "Hawaii Boasts of Most Diversified Press in the World," Editor \& Publisher, 54 (September 24, 1921): 15.

Discusses the English, Japanese, Korean, Portuguese, and Filipino newspapers in Hawaii.

1611 “Press Congress Convention," Thrum's Hawaiian Annual, 38 (1922): 139-51.

Description of the formal sessions of the 1921 World Press Congress held in Honolulu. Speeches and list of delegates included.

1612 Allen, Riley H. "Hawaii's Pioneers in Journalism," Hawaiian Historical Society Report, 1928, pp. 69-103.

History of newspapers printed in Hawaii and biographical information on people involved in development of these newspapers, beginning with missionary Elisha Loomis, who brought the first printing press to Hawaii.

1613 Jabulka, Jan. “Journalism in Hawaii," Pan-Pacific (January-March 1940): 36-39.

1614 Bradley, Harold W. The American Frontier in Hawaii: The Pioneers, 1789-1843. Stanford: Stanford University Press, 1942; reprint, Gloucester, Massachusetts: Peter Smith, 1968.

Discussion of earliest newspapers in Hawaii on pages 260-65.

1615 MacDonald, Alexander. Revolt in Paradise: The Social Revolution in Hawaii After Pearl Harbor. New York: Stephen Daye, Inc., 1944. 288 pp.

Includes information on mass media growth during wartime.

1616 Frear, Walter F. Mark Twain and Hawaii. Chicago: Lakeside Press, 1947.

Contains discussion of Twain's friendships with Hawaii newspapermen, particularly H. M. Whitney, on pages 149-63.

1617 ، ' 'Last' Hawaii Legislature Covered Fully,”' Editor \& Publisher, 82, no. 15 (April 2, 1949): 53.

Describes newspaper coverage of what was called the last pre-statehood meeting of the Territorial legislature. 
1618 “'Hawaii's Papers Hit by Waterfront Strike," Editor \& Publisher, 82, no. 27 (June 25, 1949): 26.

Describes initial press reaction to strike by International Longshoremen's and Warehousemen's Union; newspaper editorials suggest possible communist influence.

1619 “'Hawaii Strike Tests Policies of Newspapers," Editor \& Publisher, 82, no. 37 (September 3, 1949): 8.

Describes editorial reactions of Hawaii newspapers to protracted dock strike.

1620 “Roughing of Camera Men Decried," NYT, April 17, 1951, 6: 6.

Reports incident at Honolulu in which press photographers were roughed up during coverage of arrival of General MacArthur.

1621 “Air Force Regrets Manhandling Press," NYT, April 18, 1951, 5: 4.

Secretary of the Air Force expresses regrets for incident in which press photographers were roughed up while covering arrival of General MacArthur at Honolulu.

1622 "First Awards Given by Honolulu Press Club," Editor \& Publisher, 88, no. 53 (December 24, 1955): 36.

Lists recipients of Honolulu Press Club awards.

1623 “Aggressive Journalism in Hawaii Cited," Editor \& Publisher, 91, no. 52 (December 20, 1958): 44.

Lists recipients of awards given by Honolulu Press Club.

1624 Greer, Richard A. "Merchant Street Notes," Hawaiian Historical Review, 1, no. 2 (January 1963): 20-36.

Historical sketch of Honolulu's Merchant Street, site of several early printing and publishing enterprises.

1625 "Gentlemen: The Ladies of the Press," $A D V$, May 24, 1965, 1: 7.

Reports Honolulu conference for prominent women journalists from Asia, the Pacific, and the United States.

1626 Wright, Theon. Rape in Paradise. New York: Hawthorn Books, Inc., 1966. $316 \mathrm{pp}$.

An account of the 1931 Massie case with frequent critical evaluation of news coverage of the case by the Honolulu Advertiser, Honolulu Star-Bulletin, and Hawaii Höchi.

1627 Bell, Janet E. "A Project to Microfilm Hawaiian Newspapers Published Primarily Before 1900," Hawaiian Historical Review, 2, no. 4 (July 1966): 332-34.

Describes briefly the work of various libraries collecting newspapers, making bibliographies, and microfilming the newspapers.

1628 Smyser, A. A. "Hawaii and its Journalism," The Quill, 54, no. 9 (September 1966): 12-14.

Short review of many social, ethnic and other differences between Hawaii and mainland United States and how this has affected journalism in Hawaii.

1629 “Newspaper Circulations Compared," $S$-B, March 20, 1967, 1: 1.

Leading Honolulu dailies' circulations listed.

1630 "Press 'Late' in Yule Coverage," $A D V$, December 24, 1968, B-3.

Feature article on mentions of Christmas in early Hawaii newspapers. 
1631 Kagihara, Diane L. “Early Hawaii Dailies.” Unpublished Student Paper, University of Hawaii, May 16, 1969. 15 pp.

1632 Turner, Charles. "Press Competition Called Stronger," $A D V$, January 14, 1970, A-9: 1.

Article reviews statements by panel on labor issues and editorial competition between Honolulu's two major dailies.

1633 “'Hawaii Papers Fear Revised Tucson Plan," Editor \& Publisher, 103, no. 13 (March 28, 1970): 12.

Reports remarks of U.S. Representative Spark Matsunaga in support of the Newspaper Preservation Act; describes situation in regard to Honolulu newspapers.

1634 Simpich, Frederick, Jr. Anatomy of Hawaii. New York: Coward, McCann \& Geoghegan, Inc., 1971. 284 pp.

Discusses Hawaii's contemporary mass media.

1635 Jones, Bob. "The Game of the Name," Hawaii Journalism Review, 1, no. 2 (April 1971), not paged.

Examines the policies of the Hawaii press regarding identification of suspects in crimes before they are formally charged.

1636 Bowman, Pierre. "Press Hasn't Done Enough, Woman Tells UPI Editors," $S$ - $B$, October 6, 1971, A-12: 1 .

Article reviews statements of Louise McDonald, editor of publications for the University of Hawaii School of Public Health, concerning deficiencies in newspapers.

1637 Hunter, Gene. “News Coverage is Criticized," $A D V$, October 6, 1971, A-4: 3. Article reviews problems of poor press coverage of issues and events discussed at 12 th annual United Press International Conference held in Honolulu.

1638 “'Councilmen to Look into Paper Sales," $A D V$, November 20, 1971, A-8: 8.

City Council looking at what kind of newspapers can be sold on city streets.

1639 Coffman, Tom. To Catch a Wave: Hawaii's New Politics. Honolulu: Honolulu Star-Bulletin, 1972. 219 pp. 2nd edition: University Press of Hawaii, 1973. $211 \mathrm{pp}$.

An account of the 1970 Hawaii gubernatorial election campaign; with material on use of mass media in the campaign.

1640 Hooper, Paul F. “A History of Internationalism in Hawaii Between 1900 and 1940.' Ph.D. Diss., University of Hawaii, 1972. 270 pp.

Origin, purpose and history of Alexander Hume Ford's Mid-Pacific Magazine; role of the Bulletin of the Pan-Pacific Union; local publishing and radio broadcasting activities of the Institute of Pacific Relations in the 1930s.

1641 "Hawaii Enacts Its Own Law Protecting Joint Operation," Editor \& Publisher, 105, no. 28 (July 8, 1972): 28.

Reports passage of a state newspaper preservation act duplicating the federal law.

1642 “Historic Newspapers Rescued,” $S$ - B, December 14, 1972, A-23: 2.

State Library microfilming old Hawaiian newspapers. Summarized in PICN, 4, no. 1 (August 1973): 10. 
1643 "Young Reporters on the Job," $S B A$, December 16, 1973, A-20: 1.

Announces State of Hawaii public school students would interview prominent persons and prepare a special "Progress Edition" to be published in February 26, 1974 edition.

1644 Cirino, Robert. Don't Blame the People. Los Angeles: Diversity Press, 1974. $311 \mathrm{pp}$.

Cirino offers the thesis that the American media have a definite conservative bias and manipulate public opinion to serve corporate interests. Includes many references to the Honolulu Star-Bulletin.

1645 Newport, Tuck. "Taking the Public's Pulse," Hawaii Observer, no. 44 (November 19, 1974): 3.

Discusses political opinion polls conducted by Honolulu newspapers.

1646 Carmichael, Dan. "Frank Fasi and The Press: The Clash of Power," Senior Thesis, University of Hawaii, 1975. $108 \mathrm{pp}$.

Examines charges made against Honolulu newspapers by Honolulu Mayor Frank F. Fasi's campaign committee to the Honolulu Community-Media Council concerning coverage of 1974 primary campaign.

\section{Aloha Daily News}

1647 “New Resort Hotel Daily Bows Nov. 1,” $S$ - $B$, October 4, 1968, D-6: 1.

Reports plans for publication of Aloha Daily News by Worldwide Publishing Co.

\section{Another Voice}

1648 Coughlin, Dianne. "Another Voice Gives a 'Radical' Viewpoint," Hawaii Journalism Review, 2, no. 7 (November 1972), not paged.

Generally favorable review of the biweekly Another Voice.

\section{The Beacon}

1649 Hostetler, Harold. "The Beacon-They're Flirting with Journalism Down at Number 2,"' Hawaii Journalism Review, 2, no. 8 (April 1973): 3.

Reviews editorial changes in magazine in December 1972.

\section{Breeze}

1650 “New Weekly Publishing Windward," $S$ - $B$, August 18, 1966, B-3: 1.

Reports appearance of The Breeze, weekly newspaper published for residents of the North Shore of Oahu.

\section{Chinese-language Newspapers}

See also names of specific publications

1651 Hull, George C. "The Chinese in Hawaii," Mid-Pacific Magazine, 9 (March 1915): 262-67.

Chinese-language newspapers are discussed on p. 266. 
1652 Lai, Kum Pai. "The Natural History of the Chinese Language School in Hawaii.”'M.A. Thesis, University of Hawaii, 1935. $160 \mathrm{pp}$.

Chinese publications are treated in pp. 24-26.

1653 Gulick, Sidney L. Mixing the Races in Hawaii: A Study of the Coming NeoHawaiian American Race. Honolulu: Hawaiian Board Book Rooms, 1937. 220 pp. Includes reference to mass media of each language group in Hawaii.

1654 Coulter, John W., and Chee Kwon Chun. "Chinese Rice Farmers in Hawaii," University of Hawaii Research Publications, 16, no. 5 (March 1937): 65-70.

Discussion of Chinese-language publications.

1655 Chock, Lun. "Chinese Newspapers in Hawaii," Pan Pacific, 1, no. 3 (October-December 1937): 54-55.

Reviews history of various Chinese-language newspapers in Honolulu and Hilo, by former manager of Hawaii Chinese Journal.

1656 Liang, William W. Y. "The Chinese Press in the Territory of Hawaii." Edited under the auspices of the Department of Journalism, Yenching University. Collectanea Commis. Synodal, 10, no. 12, December 1937. 4 pp.

1657 Borrows, Edwin G. Chinese and Japanese in Hawaii during the Sino-Japanese Conflict. Honolulu: American Council, Institute of Pacific Relations, 1939. 79 pp.

In describing how Hawaiian residents of either Japanese or Chinese background received information about Sino-Japanese conflict, book reviews all the mass media-radio, newspapers, films, etc., available in Hawaii that might provide information on this issue.

1658 Feng, Tzu-yu. Hua ch'iao ko ming tsu chih shih hua [Historical records of overseas Chinese revolutionary organizations]. Taipei, 1954. $90 \mathrm{pp}$.

Summary of overseas Chinese revolutionary activities; includes information on two revolutionary newspapers in Honolulu, Min Sheng Daily News and Tzu Yu Hsia Pao.

1659 Pang, Loretta O. Q. "The Chinese Revolution: Its Activities and Meaning in Hawaii." B.A. Honors Thesis, University of Hawaii, 1963. 67 pp.

Deals with participation of Hawaii Chinese in Chinese political activities in the early 1900s, including activities of political organizations and Chinese-language newspapers.

1660 Feng, Ai-chün. Hua-ch'iao pao-yeh shih [History of the overseas Chinese Press]. Taipei, 1967. $136 \mathrm{pp}$.

Includes some information on a revolutionary newspaper in Honolulu.

1661 Chang, Kuo-sin. A Survey of the Chinese Language Daily Press. Hong Kong: Asian Programme, International Press Institute, 1968. 90, 58 pp.

In Chinese and English; contains brief references to Chung Hua Hsin Pao, Chinese-language daily published in Honolulu.

\section{The Citizen}

1662 “'Toyama Suspends Monthly 'Citizen,' "' $A D V$, March 14, 1964, A-8:6.

Reports suspension of The Citizen by its editor, Tetsuo Toyama, to allow work on a book. 


\section{Community Publications, Inc.}

See also Hawaii Press Newspaper.

Community Publications, Inc., began as Windward Publishing Company in the early 1970s, after Hawaii Press Newspapers ceased printing the weekly newspapers. Six weeklies published by Community Publications, Inc., are: Downtowner; HawaiiKai Sun Press; Hawaii Military Sun Press; Leeward Sun Press; Wahiawa Sun Press; Windward Sun Press. These newspapers are popularly known as the "Sun Press."

1663 “Isle Papers Stop: Dock Strike Cited,” $A D V$, October 27, 1971, D-4: 3.

Windward Publishing Company will close down its six weekly community newspapers due to rising costs and dock strike.

1664 Wright, Carl. "Publishing Firm to Stay in Business: Mainland Buyer OK's Continuation," $S$ - $B$, October 28, 1971, D-4: 3.

Windward Publishing Company has a mainland buyer who ordered the business to continue.

\section{Community Review}

1665 “'Two Publications Launched,” PICN, 4, no. 3 (May 1974): 9.

Notes first appearance of Community Review and Paradise Magazine; describes format, policies, publishers.

\section{The Friend}

1666 “'History of the Friend," The Friend, January 1911, p. 3.

Short note on origins of the magazine and its aim: Advocating temperance and good citizenship.

1667 "Oldest Newspaper West of the Rockies," The Friend, October 1921, pp. 229-30.

History of The Friend and its Hawaiian, Chinese, Japanese and Filipino editions.

1668 “The Friend's 100th Year," S-B, February 21, 1942, 20: 4.

Short note on the beginning of the 100th year of publication.

\section{Friendly Isle News}

1669 “' 'Friendly Isle News,' , $A D V$, November 20, 1955, A-4: 3.

Reports acquisition of weekly newspaper, Ka Leo O Molokai; name changed to Friendly Isle News.

\section{The Garden Island}

1670 “'Kauai Paper Reported Sold,”' $A D V$, January 5, 1966, 1: 8.

Reports sale of The Garden Island to Scripps League Newspapers; sale includes radio station KTOH.

1671 “Garden Island Employees Told Paper Will Be Sold,” $A D V$, January 6, 1966, A-10: 5 .

Reports announcement made to Garden Island employees to effect paper will be sold; no possibility seen for employees to purchase it themselves.

1672 “"Garden Isle Newspaper Will Be Sold," $A D V$, January 13, 1966, C-14: 8. Reports planned sale of The Garden Island. 
1673 “"Mike Fern Resigns as Kauai Editor," $A D V$, May 5, 1966, A-14: 1.

Reports resignation of C. J. Fern, Jr. as editor of The Garden Island.

1674 “'Woman Editor for Kauai Paper,' $A D V$, May 14, 1966, B-1: 1.

Reports appointment of Jean Holmes as editor of The Garden Island.

1675 “Schedule Changed by Newspaper,"' $S$-B, July 6, 1966, A-7: 1.

Reports The Garden Island dropping Saturday edition.

1676 “'Publisher Quits Post on Kauai,” $A D V$, July 19, 1967, D-3: 6.

Reports resignation of Fred Heldt as publisher of The Garden Island.

\section{German-Language Publications}

1677 Hörmann, Bernhard L. "The Germans in Hawaii.” M.A. Thesis, University of Hawaii, 1931. 162 pp.

See pages 98,112 .

\section{Hawaii Catholic Herald}

1678 “10th Birthday of Catholic Herald Nov. 1," $A D V$, October 23, 1946, 2: 5.

Notes observance of tenth anniversary of the Catholic Herald.

1679 “Rev. Read Named Director of Hawaii Catholic Herald," $A D V$, January 10, 1959, B-3: 5.

Reports appointment of the Rev. John Read as director of the Hawaii Catholic Herald.

1680 “Religion is Top News to Editor Marzen,” $A D V$, March 4, 1967, A-4: 3.

Feature article on Msgr. Francis Marzen, editor of the Hawaii Catholic Herald.

\section{Hawaii Farm Monthly}

1681 “'Hawaii Farm Monthly," Editor \& Publisher, 70, no. 46 (November 13, 1937): 41 .

Discusses establishment of Hawaii Farm Monthly.

\section{Hawaii Free Press}

1682 “UH Activists Plan Conference," $A D V$, June 19, 1969, C-6: 5.

Politically active University of Hawaii student group, announces that new underground newspaper, Hawaii Free Press, will replace The Roach.

\section{Hawaii Hōchi}

See also Japanese-language newspapers

1683 "Hawaii Herald Plans to Move to Liliha Area," $S$-B, February 22, 1946, 3: 6. Reports possible move of paper from its Queen Street address.

1684 "City Accepts Hawaii Hōchi Property Offer," $A D V$, March 2, 1946, 2: 4.

Reports agreement between Hawaii Hōchi owners and City of Honolulu for transfer of the newspaper's property to the city without condemnation proceedings. 
1685 "'Hochi Property to City-County Use Immediately," S-B, March 7, 1946, 1: 5.

Hawaii Hōchi property to be used immediately by Honolulu Police Station; Hōchi plant moving to another location.

1686 “Mrs. Fred K. Makino Now Hawaii Hochi Publisher," $A D V$, January 3, 1954, C-6: 1 .

Short feature on Mrs. Makino in her role as publisher.

1687 “Temple Honors Former Publisher of Hawaii Hochi," S-B, April 12, 1954, 5: 4.

Memorial temple to honor Fred K. Makino, founder and publisher of Hawaii Hōchi.

1688 "Japanese Honor Hawaiian Editor," Editor \& Publisher, 90, no. 48 (November 23, 1957): 50.

Short item reporting award presented by Japanese government to Frederick K. Makino, editor of Hawaii Herald.

1689 "Japanese Language Papers Here Unique," Sunday Advertiser, November 29, 1959, B-8: 1 .

Discusses history, formats and staffs of the Hawaii Hōchi and Hawaii Times.

1690 “Mrs. Makino's Departure from Hawaii Hochi Ends Family's 48-Year Control of Daily," $S-B$, March 3, 1961, 19: 4.

Reports retirement of Michiye (Mrs. Fred K.) Makino as president of Hawaii Hōchi; succeeded by Yasutaka Fukushima.

1691 “Japan Paper May Take Over Hochi," ADV, April 11, 1962, A-1: 2.

Reports efforts of Japanese newspaper Shizuoka Shimbun to buy control of Hawaii Hōchi.

1692 “Bilingual Dailies in Public Dispute," S-B, April 26, 1962, 1-B: 1.

Discusses dispute between Hawaii Times and Hawaii Höchi stemming from the latter's sale of its stock to a newspaper in Japan.

1693 “Mrs. Makino Will Retire as Hawaii Hochi Chairman," S-B, February 11, 1967, A-9: 3.

Reports retirement of Mrs. Fred K. Makino.

1694 “'Sakamoto New Editor of Hochi," $A D V$, February 11, 1967, C-14: 8.

Reports appointment of Lawrence Sakamoto as editor of Hawaii Hōchi.

\section{Hawaii News Service}

1695 "Young People Start Paper to Feature News of Koreans," $S-B$, March 4, 1952, 7: 1 .

Reports establishment of a semimonthly English-language newspaper, the Hawaii News Service, to feature news mainly about Koreans and Korean-Americans.

\section{Hawaii Observer}

1696 Burris, Jerry. "Hawaii Observer: Can a Serious Magazine Find Work in Honolulu?" Hawaii Journalism Review, 2, no. 8 (April 1973): 2.

Reviews bi-weekly tabloid magazine's staff and prospects in Hawaii. 


\section{Hawaii Press Newspapers}

See also Community Publications, Inc.

1697 “Hawaii State Newspapers Form New Organization,” $S-B$, March 12, 1963, 1: 6 .

Reports formation of a new corporation, Hawaii Press Newspapers, by Hawaii State Newspapers and Scripps League Newspapers.

1698 “Local Press, Mainland Firm Merge,” $A D V$, March 13, 1963, A-2: 5.

Reports formation of Hawaii Press Newspapers by Hawaii State Newspapers and Scripps League Newspapers.

1699 "'Hawaii Group of Weeklies in Scripps League," Editor \& Publisher, 96, no. 11 (March 16, 1963): 11.

Reports establishment of Hawaii Press Newspapers company through stock transactions between Scripps League Newspapers and companies owned by Stewart and Lee Fern, publishers of Pali Press and Kaneohe Citizen, Wahiawa Press, Leeward Press, Suburban Press, Hawaii Military Press, Waikiki Beach Press, Hawaii, U.S.A.

1700 “Fern Resigns Publisher Post,” $A D V$, April 1, 1965, A-7: 1.

Reports resignation of Stewart Fern as president and publisher of Hawaii Press Newspapers.

1701 “'Scripps Firm Starts Daily in Pali Area," Editor \& Publisher, 99, no. 3 (January 15, 1966): 46.

Reports conversion of weekly Pali Press to five-times-a-week publication; discusses circulation, contents of first daily edition, staff.

1702 “Morrow New Press Publisher," $A D V$, August 10, 1966, A-13: 1.

Reports appointment of Monte Morrow as publisher of Hawaii Press Newspapers.

1703 “Pali Press to be Weekly," $S$ - $B$, December 28, 1966, A-18: 1.

Reports plans to covert Daily Pali Press to weekly publication.

1704 “Publisher Quits Press Newspapers," $S$ - $B$, February 14, 1967, A-1 A: 2.

Reports resignation of Monte Morrow as publisher of Hawaii Press Newspapers.

1705 “New Publisher," $A D V$, February 20, 1967, A-8: 8.

Reports appointment of Gerald P. Fisher as publisher of Hawaii Press Newspapers.

1706 “'Hagadone's Group Has Record Year," Editor \& Publisher, 101, no. 32 (August 10, 1968): 24.

Describes program of advertising seminar for executives of Hagadone Newspapers; includes some information on expansion of Hawaii Press Newspapers, whose publisher attended seminar.

\section{Hawaii Star}

See also Japanese-language newspapers

1707 United States. Congress. House. Committee on Un-American Activities. Hearings Regarding Communist Activities in the Territory of Hawaii, Pt. 1-3. 81st Congress, 2nd Session, April 10-15, 17-19, 1950. Washington: Government Printing Office, 1950. Pt. 4. 81st Congress, 2nd Session, July 6, 1951. Washington: Government Printing Office, 1951.

Reviews activities of the U.S. House Committee on Un-American Activities in investigating Hawaii residents associated with alleged Communist organizations or newspapers. 
1708 Report on Hawaii Civil Liberties Committee, A Communist Front. Washington: Government Printing Office, June 23, 1950. 55 pp.

Reports on Communist activities in Hawaii; includes photocopies of articles from Hawaii Star and the Honolulu Record.

\section{Hawaii Times}

See also Japanese-language newspapers

1709 Sōga, Yasutarō. Gojūnenkan no Hawai kaiko [My fifty years memoirs in Hawaii]. Honolulu, 1953.713 pp.

Reminiscences of the president and editor of Hawaii Times (1873-1957).

1710 "Japanese Press in Hawaii," Mid-Pacific Magazine, 23, no. 1 (January 1922): 39-41.

Brief history of Hawaii's Japanese-language press, with editorial-type article appended praising efforts of Japanese press to Americanize Japanese residents.

1711 "The Japanese Press in Hawaii," Pan Pacific, 1, no. 2 (April-June 1937): 13-15.

Reviews early history of Japanese-language newspapers in Hawaii, including The Yamato, Nipon Shuho, Hawaii Shimbun.

1712 Wakukawa, Ernest K. A History of the Japanese People in Hawaii. Honolulu: Toyo Shoin, $1938.439 \mathrm{pp}$.

Chapter on "The Japanese Press and Periodicals in Hawaii" surveys the history of the Japaneselanguage press in Hawaii from its beginnings in 1892, with emphasis on Nippu Jiji.

1713 "George Eguchi Hits Alien Newspaper for 'Meddling'," $S$ - $B$, October 2, 1940, 2: 1 .

Legislative candidate criticizes newspaper Nippu Jiji (Hawaii Times) for meddling in American politics after paper's editor attacked candidate's statements about a former Japanese consul general.

1714 “Nippu Becomes Hawaii Times," $A D V$, October 28, 1942, 3: 5.

Reports decision of stockholders and directors to change name of Nippu Jiji to Hawaii Times.

1715 “"Honored by Japan," Editor \& Publisher, 89, no. 47 (November 17, 1956): 77.

Reports presentation of award by Japanese government to Yasutarō Sōga, editor and publisher of Hawaii Times.

1716 "Japanese Language Papers Here Unique," Sunday Advertiser, November 29, 1959, B-8: 1.

Describes background, format, staffs of Hawaii Times, Hawaii Hōchi.

1717 “Bilingual Dailies in Public Dispute," S-B, April 26, 1962, 1-B: 1.

Discusses dispute between Hawaii Times and Hawaii Hōchi stemming from the latter's sale of stock to a newspaper in Japan.

\section{Hawaii Tribune-Herald}

1718 'O'Brien Resigns as Hilo Editor," $A D V$, June 24, 1942, 3: 4.

1719 “'Harry Blickhahn New Editor of Tribune-Herald," $S$ - $B$, November 20, 1944, 8: 4 . 
1720 “ $\$ 300,000$ Building for Hawaii,” Editor \& Publisher, 81, no. 53 (December 25, 1948): 20 .

Drawing of proposed new building.

1721 "New Tribune-Herald Building Opening to be Commemorated," $S-B$, March 29, 1950, 16: 3 .

1722 "New Tribune-Herald Plant Dedicated at Hilo Ceremony," $S$ - $B$, April 10, 1950, 2-A: 1.

1723 “Honolulu Group Buys Star-Bulletin Control," Editor \& Publisher, 94, no. 47 (November 25, 1961): 15.

Reports sale of majority stock of Honolulu Star-Bulletin, Ltd.; sale includes Hilo Tribune-Herald.

1724 “Chinn Ho Is President of Star-Bulletin," $S$ - $B$, May 1, 1962, 1: 1.

Announces election of Chinn Ho as president of Honolulu Star-Bulletin and William Hill as president of Hilo Tribune-Herald.

1725 “'Star-Bulletin Passes to Hawaii Syndicate," Editor \& Publisher, 95, no. 18 (May 5, 1962): 11, 60.

Reports completion of sale of Honolulu Star-Bulletin and its properties; transaction includes Hilo Tribune-Herald.

1726 "'Hilo Tribune-Herald Is Owned by Star-Bulletin."' $S$ - $B$, August 14, 1962, 1-22: 1 .

Historical background of paper; from special 50th anniversary issue.

1727 “Hilo Tribune-Herald Sold to Westerner,” $S$ - $B$, January 17, 1964, 1: 5.

Announces sale of the Hilo Tribune-Herald by Honolulu Star-Bulletin to Donald W. Reynolds.

1728 “New Owner of Hilo Tribune-Herald Outlines Philosophy," $S$ - $B$, January 18, 1964, 1: 1 .

Donald W. Reynolds discusses his plans for the Hilo Tribune-Herald.

1729 “'Hill, Rose Quit Tribune Herald,” S-B, January 21, 1964, 1: 3.

Reports resignation of William Hill, publisher, and D. W. Rose, general manager, from Hilo Tribune. Herald after sale of the paper.

1730 “'Star-Bulletin Co. Sells Hilo Paper to Reynolds,"' Editor \& Publisher, 97, no. 4 (January 25, 1964): 16.

Reports sale of Hilo Tribune-Herald to Donald W. Reynolds.

\section{Hawaiian-language Newspapers}

See also names of specific publications

1731 Pukui, Mary K. "Old Hawaiian Newspapers." Paper Read Before the Anthropological Society of Hawaii, December 1, 1937.

1732 Mookini, Esther T. "A brief survey of the Hawaiian-language newspapers." Submitted to the Committee on Library Prizes for Pacific Island Area Research. May $12,1967.32 \mathrm{pp}$.

Review of early Hawaiian-language newspapers. Appendixes include: Major publications fron newspaper translations; selections of newspaper translations of Mary K. Pukui and Bishop Museurr Library; bibliography; chronology of the newspapers. 
1733 Reed, Judith. "Hawaiian Language Newspapers on Microfilm," Hawaii Library Association Journal, 28, no. 1 (June 1971): 33-35.

Microfilmed and yet-to-be microfilmed Hawaiian language newspapers; titles, dates, availability, and background of filming.

\section{Ka Hoaloha}

1734 Lueras, Leonard. "Ka Hoaloha-Hot Off the Press," $A D V$, December 6, 1975, A-16: 1.

Article about Louis Kaulanaula Grace, editor of the only regularly published Hawaiian-language periodical.

\section{Ka Hoku Loa}

1735 “"Native Newspapers," The Friend, January 1862, p. 1.

Reports publication of the Hawaiian-language religious newspaper, Ka Hoku Loa.

\section{Ka Hoku o Hawaii}

1736 “'Eddie Desha Making Effort to Save 'Star of Hawaii'," $S$ - $B$, October 8, 1938, 2: 1 .

Describes efforts to save weekly Hawaiian-language newspaper, Ka Hoku o Hawaii (Star of Hawaii) of Hilo.

1737 Mott, Frank Luther. A History of American Magazines, Honolulu 1885-1905. Cambridge: Belknap Press of Harvard University Press, 1957. 858 pp.

Brief description of Paradise of the Pacific on page 109.

1738 “' ‘Honolulu' Makes Colorful Debut,” $S$ - $B$, June 29, 1966, H-29: 7.

Describes magazine's first issue.

\section{Honolulu Advertiser}

1739 Whitney, Henry M. "Free and Untrammeled Press," Pacific Commercial Advertiser, July 2, 1856; reprinted in $A D V$, February 24, 1976, 1-21.

Editorial from first issue of Pacific Commercial Advertiser on July 2, 1856. Henry Whitney, founder of paper, discussed the services newspaper promised to deliver to readers.

1740 "Prospectus of the Pacific Commercial Advertiser to be Published in English and Hawaiian,' The Friend, July 1856, p. 50.

Outlines publication plans, policies, subscription price.

1741 “'Reminiscences of the Press," Thrum's Hawaiian Annual, 3 (1877): 24-27.

Very brief history of The Polynesian and the Pacific Commercial Advertiser and criticism of both.

1742 Thrum, Thomas G. “Genesis and Evolution of Honolulu's Dailies,' Thrum's Hawaiian Annual, 23 (1897): 108-111.

Traces the development of Henry M. Whitney's daily bulletin board posters recording ship movements and local business and social events into a newspaper, the Commercial Advertiser.

1743 Smith, W. G. "'History of the Advertiser," Pacific Commercial Advertiser, 50th Anniversary Edition, 1906, pp. 9-11. 
1744 “Mid-Pacific Efficient Printing Plant," Thrum's Hawaiian Annual, (1931): 105-08.

Opening of the Advertiser building on February 11, 1930; description of building and equipment.

1745 “'The Advertiser's 75th Anniversary," Thrum's Hawaiian Annual, (1932): 113-15.

Description of the July 2, 1931 anniversary issue of paper, and other aspects of the celebration.

1746 “'Hawaii Newspaper Plant Camouflage,’ Editor \& Publisher, 75, no. 28 (July 11, 1942): 30 .

Describes war precautions at Honolulu Advertiser based on letter from Lorrin P. Thurston, president and general manager.

1747 “"Picket Line at Advertiser," $A D V$, September 16, 1945, 2: 6.

Reports picket line manned by striking dairy workers, apparently protesting the paper's treatment of the strike in news stories.

1748 “24-Hour News Service Mapped By Advertiser,”' $A D V$, March 5, 1946, 1: 2.

Announces plans to begin March 11 a continuous publication cycle of two morning and two afternoon editions.

1749 “24-Hour Paper Offers Readers Tops In News,” $A D V$, March 5, 1946, 1: 2.

Account of radio broadcast announcing plans for continuous publication cycle; Publisher L. P. Thurston elaborates on rationale; Editor Raymond Coll describes operational aspects.

1750 “'Hawaii Papers At High Tempo In Tidal Wave," Editor \& Publisher, 79, no. 15 (April 6, 1946): 13.

Describes newspaper coverage of tsunamis.

1751 American Samoa. Documents in the Governor's Files in American Samoa, 1900-1949. Microfilm (5 reels) in Hamilton Library, University of Hawaii.

Reels 2 and 3 contain some reports and correspondence related to the visit in 1926, the writing, and the publicist activities of Lorrin A. Thurston, owner of the Honolulu Advertiser; also some correspondence related to Arthur A. Greene, at various times city editor of the Honolulu Star-Bulletin and Honolulu Advertiser, for which he was ordered out of American Samoa in 1920.

1752 “'Hawaii Strike Forces 2 Papers to Cut Size,” NYT, July 5, 1949, 42: 3.

Reports Honolulu daily papers decision to cut size in order to ration newsprint and continue publication during waterf ront strike.

1753 “'Austerity in Force on Honolulu Papers,"' Editor \& Publisher, 82, no. 31 (July 23, 1949): 43 .

Describes austerity programs adopted by Honolulu newspapers in face of a serious newsprint shortage.

1754 “'Newsprint Supplies in Hawaii at Tag-End," Editor \& Publisher, 82, no. 32 (July 30, 1949): 4.

Describes Honolulu newspaper austerity measures to meet newsprint shortage resulting from strike by longshoremen.

1755 “'Honolulu Advertiser Maps Merchandising,"' Editor \& Publisher, 86, no. 34 (August 15, 1953): 14.

Notes establishment of a merchandising department at Honolulu Advertiser. 
1756 “'Kenekulia for '56,' Editor \& Publisher, 88, no. 32 (July 30, 1955): 37.

Describes Honolulu Advertiser's preparations for 100th anniversary.

1757 "What the First Advertiser Was Like," $A D V$, October 23, 1955, A-14: 5.

Describes format of The Polynesian, from which are taken items for editorial feature called " 99 Years Ago Today."

1758 'Long Search Continues For Hawaii Newspapers First Press,' $A D V$, June 10, 1956, A-16: 4.

Describes efforts of researchers to locate the press used by Henry M. Whitney, founder of the Pacific Commercial Advertiser.

1759 “'History from Beginnings," $A D V$, June 23, 1956, A-23: 1.

Historical review of Honolulu Advertiser.

1760 “Centennial Edition.” $A D V$, July 1, 1956, A-1-7.

Includes seven pages of articles on Honolulu Advertiser, staff, the publisher, and historical information.

1761 “"Honolulu Advertiser A Centenarian," Editor \& Publisher, 89, no. 26 (June 23, 1956): 48.

Notes observance by Honolulu Advertiser of its 100th anniversary; brief history; describes special anniversary sections of paper.

1762 “'5 New Units In 160 Crates Double Press," Editor \& Publisher, 89, no. 33 (August 11, 1956): 48.

Short item describing new press equipment being installed at Honolulu Advertiser.

1763 “'Hawaii Editor Wins Election to Senate," Editor \& Publisher, 89, no. 47 (November 17, 1956): 66.

Short item reporting the election of Oren E. Long, associate editor of the Honolulu Advertiser, to the Territorial Senate.

1764 “'Youth Tabloid Is Supplement In Honolulu," Editor \& Publisher, 90, no. 20 (May 11, 1957): 32.

Describes content and editing of youth supplement published with the Sunday Advertiser.

1765 “'Huge HD Project 'Running Smoothly',' Editor \& Publisher, 90, no. 25 (June 15, 1957): 76.

Short item on functioning of Honolulu Advertiser home delivery system.

1766 “'Statehood Edition." $A D V$, June 23,1959, A-23: 1.

Article tracing the history of the Advertiser.

1767 “'Survey Shows Readers Prefer Star-Bulletin,', Sunday Star-Bulletin, May 28, 1961, 1:2, 2: 1 .

Survey shows preferences for Star-Bulletin and Advertiser, whether readers receive one or two newspapers a day, and readership by income levels.

1768 "Joint Production Plan Arranged for Honolulu," Editor \& Publisher, 95, no. 22 (June 2, 1962): 9.

Describes plans of Honolulu Advertiser and Honolulu Star-Bulletin to form a third company to handle production, business, advertising, and circulation for both papers. 
1769 “Papers Form Jointly-owned Third Firm,"' $A D V$, June 2, 1962, A-1: 3.

Reports establishment of the Hawaii Newspaper Agency, jointly owned by the Honolulu Advertiser and Honolulu Star-Bulletin, to handle business, production, advertising, and distribution functions for both newspapers.

1770 "Questions and Answers on Newspaper Move," $A D V$, June 3, 1962, 1: 1; $S$ - $B$, June 3, 1962, 1: 1 .

Gives reasons for formation of joint production company.

1771 “To Our Readers,"' Sunday Avertiser, June 24, 1962, A-1: 6.

Announces beginning of publication of combined Sunday edition with the Honolulu Star-Bulletin.

1772 “Publisher Says Newspaper Plan Saves Honolulu from Monopoly," $A D V$, September 26, 1962, B-8: 5 .

The publisher of the Honolulu Advertiser, Thurston Twigg-Smith, defends joint operating arrangement on local radio program.

1773 “U.S. Probe of Honolulu Papers Set,” $A D V$, March 22, 1963, A-1: 4.

Reports Justice Department announcement that it will begin an anti-trust investigation of the Honolulu Advertiser and Honolulu Star-Bulletin as a result of the newspapers' formation of a joint production company.

1774 "'Tricky Structural Job Executed On Building in Hawaii," Editor \& Publisher, 96, no. 15 (April 13, 1963): 48.

Describes alterations to Honolulu Advertiser building to accommodate Honolulu Star-Bulletin and their joint production company.

1775 “'Post-Strike Honolulu Newsstand Sales Up,'” Editor \& Publisher, 96, no. 33 (August 17, 1963): 13.

Reports increased sales of first editions of Honolulu newspapers at the end of newspaper strike; describes content of first issues; discusses effect of strike on business.

1776 “Advertiser Minority Stock Optioned to Copley Press," $S$ - B, November 5, $1963,1: 4$.

Reports purchase of part-interest in Honolulu Advertiser by Copley Newspapers of California.

1777 “'Copley Cites Interest in 'Tiser and Hawaii,' $A D V$, January 15, 1964, A-7: 1.

Reports purchase of 34 percent of stock in Honolulu Advertiser by Copley Newspapers.

1778 “'Star-Bulletin Co. Sells Hilo Paper to Reynolds,'” Editor \& Publisher, 97, no. 4 (January 25, 1964): 16.

Reports sale of Hilo Tribune-Herald by Honolulu Star-Bulletin to Donald W. Reynolds.

1779 “Thurston Comments On His Resignation,” $S$ - $B$, February 25, 1964, A-1: 1.

Lorrin P. Thurston's statement on his resignation as a member of the board of directors of the Honolulu Advertiser.

1780 “" $\$ 31,385$ Operating Profit Shown by 'Tiser In 1963," $A D V$, April 1, 1964, B-5: 4.

A report on the Honolulu Advertiser's annual earnings.

1781 “'Honolulu Papers' Production Plant In Full Operation,'” Editor \& Publisher, 97, no. 50 (December 12, 1964): 53.

Describes improvements in physical plant of Honolulu Advertiser-Honolulu Star-Bulletin. 
1782 “Copley Sells His Advertiser Stock,”' $A D V$, September 10, 1966, A-1: 7.

Reports sale by Copley Newspapers of its 34 percent interest in the Honolulu Advertiser to the TwiggSmith family.

1783 “New Dress for Her 113th Anniversary," Editor \& Publisher, 102, no. 38 (September 20, 1969): 36.

Describes promotional campaign associated with format changes in Honolulu Advertiser.

1784 Benson, Bruce. “All the News That Fits," Hawaii Journalism Review, 1, no. 1 (February 1971), not paged.

Criticizes Honolulu Advertiser policy restricting length of news stories.

1785 Fawcett, Denby. “Your Guide to Dining Out or: How to Make Coco's Sound Like Michel's,'” Hawaii Journalism Review, 1, no. 1 (February 1971), not paged.

Criticizes the magazine section of the Sunday Star-Bulletin and Advertiser for failing to make explicit the fact that stories on restaurants are tradeoffs for advertising and are written to flatter the restaurants.

1786 Haugen, Keith. “Ever On Sunday,” Hawaii Journalism Review, 1, no. 4 (July 1971), not paged.

Honolulu Star-Bulletin staff member criticizes Honolulu Advertiser staff for starting multi-part stories in the combined Sunday edition of the two papers.

1787 Jones, Bob. “News Space for Sale,” Hawaii Journalism Review, 1, no. 4 (July 1971), not paged.

Criticizes the "Hawaii Living" section of the Sunday Star-Bulletin and Advertiser for presenting promotional stories on advertisers as legitimate news.

1788 “Conductor Admittedly Lacks Punch,' Hawaii Journalism Review, 1, no. 7 (November 1971), not paged.

Discusses book reviewing as carried on in the pages of the magazine supplement to the Sunday StarBulletin and Advertiser.

1789 Milz, Barbara. “'Divorce Advertiser Style,'” Hawaii Journalism Review, 2, no. 4 (April 1972), not paged.

Honolulu Advertiser reporter discusses pressures on newspaper to withhold publication of embarrassing news items.

1790 "City Credits 'Tiser Series for Extra Aid from HEW," $A D V$, February 23, 1973, A-1: 1 .

Reports Advertiser article on plight of Hawaii elderly, written by Sanford Zalburg, was key factor in State obtaining funds for Oahu's senior citizens.

1791 “'Look Closely-You Won't See It Again,”' $A D V$, July 30, 1973, A-1: 1.

Announces final edition of Advertiser to use the "hot type" composition process; next edition would use computerized photo-chemical process.

1792 “A Reply to Fasi's Attack on Press," $A D V$, February 28, 1974, A-11: 1.

Letter sent by Advertiser Editor-in-Chief George Chaplin to Kona Rotarians and realtors explaining conditions leading to mutual publishing plans of the Advertiser and Star-Bulletin in answer to Mayor Frank Fasi's speech to those organizations. 
1793 "'Ombudsman Named at Paper to Check on Reader Complaints," $S B A$, April 7, 1974, A-1: 3 .

Advertiser announcement.

1794 Ware, Charles. “Ombudsman Reports," $S B A$, May 12, 1974, B-2: 5.

Advertiser ombudsman explains types of problems he has been asked to deal with in first month of job.

1795 “No Kid, But Still Growing," $A D V$, July 2, 1975, A-1: 5.

Notes Advertiser at its 120 th year of publication.

1796 “'Our 'Other Voices',' $S B A$, October 5, 1975, B-2: 1.

Advertiser announces that community people would be selected to express their viewpoints on the editorial page.

\section{Honolulu Record}

1797 United States. Congress. House. Committee on Un-American Activities. Hearings Regarding Communist Activities in the Territory of Hawaii, Pt. 1-3. 81st Congress, 2nd Session, April 10-15, 17-19, 1950. Washington: Government Printing Office, 1950. Pt. 4. 81st Congress, 2nd Session, July 6, 1951. Washington: Government Printing Office, 1951.

Record of questions asked Hawaii residents by U.S. Government Committee on Un-American activities; included are employees of the Honolulu Record.

1798 Report on Hawaii Civil Liberties Committee, A Communist Front.

Washington, D.C. June 23, 1950. 55 pp.

Reports on Communist activities in Hawaii; includes photocopies of articles from Hawaii Star and the Honolulu Record.

1799 Report on the Honolulu Record. 81st Congress, 2nd Session. Washington: Government Printing Office, $1950.38 \mathrm{pp}$.

Reviews ownership and staff of Honolulu Record and background of these personnel and their relationship to the Hawaii Civil Liberties Committee, an organization considered by the U.S. House Committee on Un-American Activities to be a Communist front organization.

1800 Cunningham, James F. "W. K. Bassett Scolded for News Column," $A D V$, January 29, 1951, 1: 1 .

Reports release of House Un-American Activities Committee report on the Honolulu Record; summarizes report, which labels paper a front for the Communist Party and notes W. K. Bassett, administrative assistant to the mayor of Honolulu, wrote a column for the newspaper.

1801 "Bassett Says Record Was Too Leftist for Him," ADV, January 30, 1951, 1:

4.

Reports statement of W. K. Bassett, administrative assistant to the mayor of Honolulu, that he had not written for the Honolulu Record for the past two years because the paper had become too sympathetic to communism.

1802 “'Honolulu Aide Replies,” NYT, January 30, 1951, 3: 1.

W. K. Bassett, administrative assistant to the mayor of Honolulu, denies having written for the Honolulu Record in the preceding two years; U.S. House Un-American Activities Committee had charged he aided the Communist cause by writing for the newspaper. 
1803 United States. Congress. House. Committee on Un-American Activities. Annual Report for the Year 1951. February 17, 1952.30 pp. Appendixes.

Continuation of Committee on Un-American Activities Reports. Includes complete set of U.S. Government "Proceedings Against . . ." all indicted persons.

1804 Hewlett, Frank. "Honolulu Record Branded Red 'Propaganda Avenue'," $S-B$, September 21, 1953, 1: 5 .

Discusses brief mention of Honolulu Record in publication Communist Underground Printing Facilities and Illegal Propaganda, the published report of hearings held by the U.S. Senate Internal Security Subcommittee.

1805 International Longshoremen and Warehousemen's Union. Defense Committee. Hawaii Smith Act Trial; Weekly Report. No. 1-27. November 7, 1952-May 23, 1953.

Weekly summary of proceedings in trial of seven persons accused of violating the Smith Act; defendants included two staff members of the Honolulu Record.

1806 Running Story: Hawaii Smith Act Trial. No. 1-237. November 5, 1952-July 3, 1953.

Summaries of trial testimony issued generally twice daily.

1807 “Public Officials Buy Space In 'Record': It Praises Reds," S-B, September 9, 1955, 1: 3 .

Reports purchase of advertisements in Honolulu Record by public officials; lists purchasers.

1808 "Cuddling Up to the Honolulu Record," $S-B$, December 26, 1955, A-8: 1.

Editorial criticizing public officials who support the Honolulu Record.

1809 "Murakami Says Ad in Record Not His Doing," $S-B$, December 29, 1955, A-4: 3 .

Honolulu City-County auditor, James Murakami, denies placing advertisement in Honolulu Record.

1810 "Nine Office Holders Buy Ads in Honolulu Record," $A D V$, August 31, 1956, A-12: 4 .

Reports the purchase by nine public officials of advertisements in an anniversary edition of the Honolulu Record; lists purchasers.

1811 Thurston, Lorrin P. "Communism Does Not, and Never Will, Control Hawaii." Honolulu: Hawaii Statehood Commission, 1957. 10 pp.

The chairman of the Hawaii Statehood Commission argues that the Honolulu Record and International Longshoremen and Warehousemen's Union radio broadcasts have no significant influence in Hawaii.

1812 Reinecke, John E. "The Big Lie of 1920: How Planters and Press Used the Big Lie of 'Japanese Conspiracy' in Breaking the Oahu Sugar Strike." Honolulu, 1958. Paging varies.

Articles written for publication in the Honolulu Record in early 1958 in anticipation of a strike by sugar workers; articles were intended to counter expected red-baiting tactics by employers; this did not occur and articles weren't used. 
1813 “'Honolulu Record Suspends Publication,”' $S$ - $B$, July 3, 1958, 1: 5.

Announces paper closing after almost 12 years of publishing. Reason given was that paper planned to stop the previous year, but remained in operation to report on the sugar industry negotiations and subsequent strike.

1814 Tsutsumi, Fred. “'Hawaii Seven' Smith Act Case,” Hawaii Pono Journal, 2, no. 1 (June 1972): 2-31.

History of the case based on newspapers and International Longshoremen and Warehousemen's Union publications; two trial defendants were staff members of the Honolulu Record.

\section{Honolulu Star-Bulletin}

1815 “A Modern Newspaper,"' $S$ - $B$, February 27, 1929, 6: 1.

Editorial statement on how the newspaper reports and publishes the news.

1816 “Announcement,"' $S$ - $B$, January 28, 1937, 1: 6.

Announces addition of United Press day report; already receiving Associated Press day and night reports and United Press business and economic service.

1817 “Advertising News and Notes," NYT, January 12, 1942, 24: 2.

Reports circulation increase of Honolulu Star-Bulletin since outbreak of war.

1818 "'Honolulu Star-Bulletin Marks 30 Years of Newspaper Service," $S$ - $B$, July 1, 1942, 7: 1 .

A brief history.

1819 “'Honolulu Paper Averages 16 Pages Daily," Editor \& Publisher, 76, no. 45 (November 6, 1943): 22.

Describes Star-Bulletin's adjustment to war-induced shortages.

1820 “An Imposing Building for Honolulu," Editor \& Publisher, 80, no. 11 (March 8, 1947): 61.

Describes building proposed to house Star-Bulletin.

1821 "Hawaii Papers at High Tempo In Tidal Wave," Editor \& Publisher, 79, no. 15 (April 6, 1948): 13.

Describes newspaper coverage of tsunami.

1822 “'Star-Bulletin, INS Set New First with Direct N.Y. Copy," $S$ - $B$, July 8, 1948, 13: 5 .

Reports first transmission of news copy directly from International News Service in New York to a teleprinter in the Star-Bulletin news room.

1823 “'Honolulu Boycott of Paper Scotched," NYT, June 29, 1949, 10: 2.

Discusses attempts to have merchants stop advertising in the Star-Bulletin as a reprisal for its lagging opposition to a dock strike.

1824 “'Hawaii Strike Forces 2 Papers to Cut Size," NYT, July 5, 1949, 42: 3.

Reports decision of Honolulu daily newspapers to reduce size, ration newsprint to continue publishing during waterfront strike.

1825 “'Newsprint Supplies in Hawaii at Tag-End," Editor \& Publisher, 82, no. 32 (July 30, 1949): 4.

Describes newspaper austerity programs to meet newsprint shortage caused by dock strike. 
1826 “'Star-Bulletin's Huge Press Officially in Service Today,'” $S$ - $B$, January 31, 1951, 23: 1 .

1827 “Six Column Pages Used in Honolulu,' Editor \& Publisher, 89, no. 19 (May 5, 1956): 50 .

Describes experimental makeup changes at Star-Bulletin.

1828 “'Honolulu Star-Bulletin Exposes 'Faith Healer','” Editor \& Publisher, 90, no. 1 (January 5, 1957): 32.

Short item describing an expose series.

1829 “'History of Honolulu Star-Bulletin," $S$ - $B$, April 14, 1959, D-9: 1.

Brief history of newspapers in Hawaii, with emphasis on the Star-Bulletin.

1830 “'New Sunday Edition Nov. 1 in Honolulu," Editor \& Publisher, 92, no. 41 (October 10, 1959): 13.

Reports plans of Honolulu Star-Bulletin to begin publication of a Sunday morning edition.

1831 “'Changes in Honolulu: Ewing is New Editor,"' Editor \& Publisher, 93, no. 31 (July 30, 1960): 34.

Reports retirement of Editor Riley $\mathrm{H}$. Allen and other staff changes.

1832 “'Survey Shows Readers Prefer Star-Bulletin," Sunday Star-Bulletin, May 28, $1961,1: 2,2: 1$.

Survey shows preferences for Star-Bulletin and Advertiser, whether readers receive one or two newspapers a day, and readership by income levels.

1833 “'Honolulu Group Buys Star-Bulletin Control,'” Editor \& Publisher, 94, no. 47 (November 25, 1961): 15.

Reports sale of Honolulu Star-Bulletin and its broadcast properties by the W. R. Farrington Estate to a group of Honolulu businessmen.

1834 “'Sale of 'Honolulu Star-Bulletin' Fought by Mrs. Farrington,' Advertising Age, 32, no. 49 (December 4, 1961): 91.

Describes efforts of Elizabeth Farrington to block sale of Honolulu Star-Bulletin by the trustees of the W. R. Farrington Estate.

1835 "Honolulu Star-Bulletin Sale Arrangement OK'd by Court," Editor \& Publisher, 94, no. 49 (December 9, 1961): 11, 72.

Detailed account of sale negotiations and court rejection of a suit to block the sale.

1836 “'Mrs. Farrington Ends Opposition to Sale," Editor \& Publisher, 94, no. 51 (December 23, 1961): 12.

Reports withdrawal of suit to block sale of Honolulu Star-Bulletin.

1837 “'Sale Closing in Honolulu Set April 30," Editor \& Publisher, 95, no. 13 (March 31, 1962): 13.

Reports plans for formal signing of contact for sale of Star-Bulletin and its properties by Farrington Estate to a group of Honolulu businessmen.

1838 “Chinn Ho is President of Star-Bulletin,” $S$ - B, May 1, 1962, 1: 1.

Announces election of Chinn Ho as president of the Star-Bulletin; William Hill named president of Hilo Tribune-Herald. 
1839 “'Star-Bulletin Passes to Hawaii Syndicate," Editor \& Publisher, 95, no. 18 (May 5, 1962): 11, 60.

Reports conclusion of sale of Star-Bulletin by W. R. Farrington Estate to a group of Honolulu businessmen; Chinn Ho elected president; reviews sale negotiations.

1840 “'A Statement to Our Readers,”' $S$ - $B$, June 1, 1962, 1: 1.

Announces agreement on joint production facilities for Honolulu Star-Bulletin and Honolulu Advertiser.

1841 “Joint Production Plan Arranged for Honolulu," Editor \& Publisher, 95, no. 22 (June 2, 1962): 9.

Describes plans of Honolulu Advertiser and Honolulu Star-Bulletin to form a third company to handle production, business, advertising, and circulation for both newspapers.

1842 "Questions and Answers on Newspaper Move," $S$-B, June 3, 1962, 1: 1; $A D V$, June 3, 1962, 1: 1 .

Explains joint production arrangement established by the Honolulu Star-Bulletin and Honolulu Advertiser.

1843 “'Chinn Ho Describes How His Group Acquired Paper," Editor \& Publisher, 96, no. 26 (June 29, 1963): 9, 50.

Ho's description of acquisition of Honolulu Star-Bulletin.

1844 “'Post-Strike Honolulu Newsstand Sales Up,'” Editor \& Publisher, 96, no. 33 (August 17, 1963): 13.

Reports increased newspaper sales with resumption of publication after strike; describes content of first editions; discusses effect of strike on business.

1845 “'Star-Bulletin Co. Sells Hilo Paper to Reynolds,"' Editor \& Publisher, 97, no. 4 (January 25, 1964): 16.

Reports sale of Hilo Tribune-Herald to Donald W. Reynolds.

1846 “'Honolulu Papers' Production Plant in Full Operation,”' Editor \& Publisher, 97, no. 50 (December 12, 1964): 53.

Describes improvements to physical plant of Honolulu Advertiser and the Star-Bulletin.

1847 “'Hawaii and Bechuanaland Linked by Aloha Program," Editor \& Publisher, 99, no. 34 (August 20, 1966): 46.

Describes goodwill program sponsored by Honolulu Star-Bulletin linking Hawaii and Bechuanaland (Botswana).

1848 Pratte, Paul A. "Everything is Under Control," The Quill, 54, no. 12 (December 1966): 12-15.

Describes Star-Bulletin coverage of 1941 attack on Pearl Harbor.

Emphasizes the characteristics of the newspaper, influential figures within the newspaper company, and various editorial campaigns. (An abstract of the thesis appears in Journalism Abstracts: M.A., M.S., and Ph.D. Theses in Journalism and Mass Communication, 6 (1968): 162-63.) 
1850 “'Chinn Ho's Group Buys Guam Paper,” Editor \& Publisher, 103, no. 4 (January 24, 1970): 16.

Reports agreement for purchase of Guam Daily News and its Sunday edition, Territorial Sun, by Guam Publications, Inc., owned by Honolulu Star-Bulletin.

1851 “S-B Subsidiary Has Option to Purchase Samoa Paper," $S$ - B, August 21, 1970, 2: 1 .

Reports option agreement for purchase of majority stock of a Samoan newspaper by Star-Bulletin subsidiary, Guam Publications, Inc.

1852 “'Increased Pacific Newspaper Activity,” PICN, 1, no. 2 (September 1970): $1-2$.

Discusses expansion of Honolulu Star-Bulletin into Guam; options for Samoa.

1853 “"Mayor Has His Column in Interest of Fair Play," Editor \& Publisher, 104, no. 1 (January 2, 1971): 20.

Describes column in Star-Bulletin written by mayor of Honolulu.

1854 “'Honolulu Group Buys Papers in W. Virginia," Editor \& Publisher, 104, no. 5 (January 30, 1971): 9.

Reports the purchase by the owners of the Honolulu Star-Bulletin of the Huntington, W. Va., HeraldDispatch and Advertiser.

1855 Fawcett, Denby. "Your Guide to Dining Out or: How to Make Coco's Sound Like Michel's," Hawaii Journalism Review, 1, no. 1 (February 1971), not paged.

Criticizes the magazine supplement of the Sunday Star-Bulletin \& Advertiser for failing to make explicit the fact that stories on restaurants are advertising tradeoffs and written to flatter the restaurants.

1856 Jones, Bob. “News Space for Sale,’ Hawaii Journalism Review, 1, no. 4 (July 1971), not paged.

Criticizes the "Hawaii Living" section of the Sunday Star-Bulletin \& Advertiser for presenting promotional stories about advertisers as legitimate news.

1857 “'Gannett to Acquire Hawaii Newspapers,”' NYT, August 3, 1971, 25: 3.

Reports plans of Gannett Company to buy the Honolulu Star-Bulletin and five other papers owned by the Star-Bulletin.

1858 "Deal Made for Star-Bulletin Newspapers to Join Gannett," Editor \& Publisher, 104, no. 32 (August 7, 1971): 8.

Reports agreement for acquisition by the Gannett Company of Honolulu Star-Bulletin and its Guam, West Virginia, and South Dakota newspapers in a stock-exchange transaction.

1859 "Gannett Completes Deal with Honolulu Company," NYT, November 2, 1971, 53: 2 .

Reports Gannett Company's acquisition of the six newspapers owned by the Honolulu Star-Bulletin, Inc.

1860 Wernet, Bob. "Tea and Sympathy in Mainland China," Hawaii Journalism Review, 1, no. 7 (November 1971), not paged.

Recounts Star-Bulletin reporter Arlene Lum's trip to China.

1861 “'Scott Appointed to Top Positions at Star-Bulletin," Editor \& Publisher, 104, no. 52 (December 25, 1971): 13.

Reports executive appointments at Honolulu Star-Bulletin. 
1862 Fawcett, Denby. “Gannett 'Steamroller' Rolls Through S-B," Hawaii Journalism Review, 2, no. 5 (May 1972), not paged.

Discusses editorial changes at Honolulu Star-Bulletin following acquisition of the newspaper by the Gannett group.

1863 “Union Chief Claims Bias in Reporting," $S-B$, April 6, 1973, A-14: 1.

Reports AFL-CIO leader charges Star-Bulletin with biased reporting, mainly about taxi bill which was pending in Legislature.

1864 "South Pacific Edition of Star-Bulletin Planned," S-B, June 7, 1973, A-2: 1.

Announces plans for Star-Bulletin to begin fall publication of a weekly edition to be distributed in the South Pacific region; to feature news about Canada and the U.S.A.

1865 Benson, Bruce. "New Era Beginning for Isle Papers," $A D V$, July 28, 1973, B-1: 1 .

Reviews technical details of "letterflex," new composing system for Honolulu Star-Bulletin and Advertiser, beginning July 1973.

1866 “'Star-Bulletin's China Stand Hailed," S-B, October 1, 1973, A-18: 1.

Reports Hawaii-Chinese People's Friendship Association complimented Star-Bulletin's abolishing prejudicial references about the People's Republic of China (such as "Red" China, etc.); change in policy has improved friendship, according to association.

1867 "Star-Bulletin Wins Citation from Editors," S-B, November 19, 1973, A-11:

2.

National Convention of Newspaper Executives awarded Star-Bulletin the "Freedom of Information" award because of its court battle to publish interviews with underworld figure.

1868 Chapman, Ronald, and Takumi Tashima. "Preserving Hawaii's History: Microfilming the Predecessors of the Honolulu Star-Bulletin," Hawaii Library Association Journal, 31, no. 2 (December 1974): 30-32.

Account of microfilming of the Daily Bulletin, the Evening Bulletin and the Hawaiian Star.

1869 Middlesworth, Mike. "Another Effort to 'Get it Right'," $S B A$, February 2, 1975, B-2: 3.

Announces two-week trial of "accuracy checklist" to be sent to randomly selected persons involved in news stories.

1870 Pratte, Paul Alfred. "Ke Alaka'i: The Role of the Honolulu Star-Bulletin in the Hawaiian Statehood Movement." Ph.D. Dissertation, University of Hawaii, 1976. $294 \mathrm{pp}$.

Describes role of Star-Bulletin as leader in Hawaii statehood movement; examines lives and work of four major decision-makers involved in the Star-Bulletin crusades.

1871 Edwards, Edwin R. "Newsroom Facelift," S-B, February 16, 1976, B-1; B-3.

Pictorial article showing changes: teletype machines going into sound-proof room.

\section{Hsin chung kuo jih pao}

1872 "New China Daily Press Celebrates 50th Anniversary March 25," S-B, March 20, 1950, 12: 1 .

Reviews history of daily which was established in 1900 by Liang Ch'i-chao with assistance of Dr. K. E. Li. 
1873 "Community Leaders Pay Respects to New China Daily Press at Dinner," $S-B$, March 28, 1950, 21: 1 .

Describes observance of fiftieth anniversary of Hsin chung kuo jih pao (New China Daily Press).

1874 "Miss Li Succeeds Father in China Press Position," $A D V$, July 22, 1954, C-6: 6.

Short item reporting selection of Li Ling-ai to be a director of Hsin chung kuo jih pao.

1875 Chang, Kuo-sin. A Survey of the Chinese Language Daily Press. Hong Kong: Asian Programme, International Press Institute, 1968.90 pp. and $58 \mathrm{pp}$.

In Chinese and English; brief references to Hsin chung kuo jih pao in Honolulu.

1876 Li, Ling-ai. Life is for a Long Time: A Chinese Hawaiian Memoir. New York: Hastings House, 1972. 343 pp.

Memoir includes references to New China Daily News.

\section{Japanese-Language Newspapers}

See also names of specific publications

1877 Conroy, Francis Hilary. "The Japanese Expansion into Hawaii, 1868-1898." Ph.D. Dissertation, University of California, Berkeley, 1949. 310 pp.

Discussion of Japanese newspapers on pp. 191-94.

1878 The Japanese Frontier in Hawaii, 1868-1898. Berkeley: University of California Press, 1953. 175 pp.

Brief sketch of Japanese-language newspapers in Hawaii in the 1890 s is on pp. 104-5.

1879 Morita, Sakae. Hawaii Nihonjin hatten shi [History of Japanese development in Hawaii]. Tokyo: Shineikan, 1916; republished in 1919 as Hawaii gojūnen shi [Fifty years of Hawaiian history]. Paging varies.

See especially pp. 426, 428-29, 434 for discussion of newspapers in Hawaii.

1880 Sōga, Yasutarō. "The Japanese Press in Hawaii," Mid-Pacific Magazine, 23, no. 1 (January 1922): 39-41.

A short history.

1881 Nakano, Suyeo. "Japanese Papers Abroad," The Trans-Pacific, November 10, 1928, 7: 4 .

Brief survey of Japanese-language newspapers in East Asia, the United States, including Hawaii, and South America.

1882 Sakamaki, Shunzo. "A History of the Japanese Press in Hawaii." M.A. Thesis, University of Hawaii, 1928. $166 \mathrm{pp}$.

General historical background on Japanese in Hawaii; discussion of Japanese-language news service, advertising, editorial policies, problems; brief histories of the papers.

1883 Mellen, George. "Americanization of Japanese," Mid-Pacific Magazine, 39, no. 6 (June 1930): 559-62.

See p. 562 on the importance of Japanese-language newspapers as an advertising medium. 
1884 Ebara, Hachirō. Kaigai hōji shinbun zasshi shi [A history of Japanese newspapers and magazines abroad]. Tokyo, 1936. $372 \mathrm{pp}$.

Traces development of Japanese periodicals in countries to which Japanese immigrated; pp. 79-103 deal with Hawaii; appendix contains bibliography of newspapers and magazines with dates and editors.

1885 Sōga, Yasutarō. "The Japanese Press in Hawaii," Pan-Pacific, 1, no. 2 (1937): 13-15.

A short history.

1886 Gulick, Sidney L. Mixing the Races in Hawaii: A Study of the Coming NeoHawaiian American Race. Honolulu: Hawaiian Board Book Rooms, 1937. 220 pp.

Includes reference to mass media of each language group in Hawaii.

1887 Wakukawa, Ernest K. A History of the Japanese People in Hawaii. Honolulu: Toyo Shoin, 1938. 439 pp.

Contains a chapter on "The Japanese Press and Periodicals in Hawaii," surveying the history of the Japanese-language press from its beginnings in 1892; discusses the Japanese-language press in Hawaii and official pressures on it; lists 12 publications appearing at time of writing.

1888 Burrows, Edwin G. Chinese and Japanese in Hawaii during the Sino-Japanese Conflict. Honolulu: American Council, Institute of Pacific Relations, 1939. 79 pp.

In describing how Hawaiian residents of either Japanese or Chinese background received information about Sino-Japanese conflict, book reviews the mass media: radio, newspapers, etc., available in Hawaii that might provide information on this issue.

1889 Kawahara, Kimie, and Yuriko Hatanaka. "The Impact of War on an Immigrant Culture," Social Process in Hawaii, 8 (1943): 36-45.

Describes the impact of World War II on residents of Japanese ancestry in Hawaii; includes some brief references to the effects of the loss of Japanese-language newspapers, broadcasts, and motion pictures.

1890 Lind, Andrew W. Hawaii's Japanese: An Experiment in Democracy. Princeton: Princeton University Press, 1946. 264 pp.

Contains brief references to Japanese-language newspapers and broadcasting.

1891 Kimura, Yukiko. "A Sociological Analysis of Types of Social Readjustment of Alien Japanese in Hawaii Since the War." M.A. Thesis, University of Hawaii, 1947. 248 pp.

The role and influence of the mainland Japanese press is discussed in pp. 49-60.

1892 Storm, Birch. “Japanese Language Newspapers Here are Unique," Sunday Advertiser, November 29, 1959, B-8: 1.

Reviews successes of Hawaii Times and Hawaii Hōchi, long time Japanese-language newspapers in Hawaii.

1893 United Japanese Society of Hawaii. Publication Committee, ed. Hawai Nihonjin imin shi [A history of Japanese immigrants in Hawaii]. Honolulu: United Japanese Society of Hawaii, 1964. 501 pp.

Japanese-language periodicals are treated in pp. 494-97. 
1894 Richstad, Jim A. "The Press and the Courts Under Martial Rule in Hawaii During World War II-From Pearl Harbor to Duncan v. Kahanamoku." Ph.D. Dissertation, University of Minnesota, 1967.420 pp.

Contains section on the closure and reopening, under censorship, of the Japanese-language press in Hawaii during World War II.

1895 United Japanese Society of Hawaii. Publication Committee, ed. A History of Japanese in Hawaii. Honolulu: United Japanese Society of Hawaii, 1971. 431 pp.

An English-language history of Japanese immigrants in Hawaii; pp. 231-35 give a sketchy history of Japanese-language newspapers.

\section{Jitsugyō no Hawaii}

1896 “'Language Paper to Observe Its 30th Anniversary," S-B, July 17, 1941, 13: 3.

Announces scheduled program to commemorate founding of Jitsugyo no Hawaii.

1897 Toyama, Tetsuo. Eighty Years in Hawaii. Tokyo: Tosho Printing Co., 1971. $183,310 \mathrm{pp}$.

Reminiscences, in English and Japanese, of the editor and founder of Jitsugyo no Hawaii and The Citizen.

\section{Kona Echo}

1898 “J. B. Dixon to Edit Revived 'Kona Echo'," $A D V$, February 4, 1950, 9: 4.

Describes plans to publish a new Kona Echo; sketchy background of earlier paper of same name.

1899 “'Kona Now Has Weekly Newspaper," $A D V$, May 14, 1951, 6: 3.

Brief item describing the revived Kona Echo.

\section{Kona Star}

1900 “Broadcasting Firm Starts Kona Paper," S-B, October 20, 1967, B-7: 1.

Reports establishment of weekly Kona Star by Mauna Loa Broadcasting Corp.

\section{Kona Torch}

1901 “New Kona Resident to Start Journal," $A D V$, July 17, 1961, B-3: 7.

Reports plans of John Lenk to start a weekly mimeographed newspaper, the Kona Torch.

\section{Korean-Language Newspapers}

See also names of specific publications

1902 Kim, Wøn-yong (Warren Y. Kim). Chaemi Han-in osip-nyon sa [Fifty-year history of Koreans in America]. Reedley, California: privately printed, 1959. 513 pp.

A survey history of the activities of Korean immigrants in the United States by a one-time resident of Hawaii; includes publishing activities.

1903 Kim, Warren Y. Koreans in America. Seoul: Po Chin Chai Printing Co., Ltd., 1971. $161 \mathrm{pp}$.

A revised English-language version of 1959 publication. 


\section{Ka Leo o Molokai}

1904 “' 'Friendly Isle News,' " $A D V$, November 20, 1955, A-4: 3.

Reports acquisition of weekly Ka Leo o Molokai by Marie Hallard and change of name to Friendly Isle News.

\section{Molokai Reporter}

1905 “New Molokai Newspaper Inaugurated,” $A D V$, November 5, 1969, B-8: 8.

Notes appearance of first edition of semimonthly Molokai Reporter.

\section{Nonanona}

1906 “Nonanona," The Friend, April 1845, p. 50.

Notes demise of semimonthly Nonanona.

\section{Ka Nupepa Kuokoa}

1907 "Hawaiian Paper Ends Publication," NYT, March 11, 1928, IX-11: 8.

Reports discontinuance of Ka Nupepa Kuokoa.

1908 Johnson, Rubellite K., ed. Ka Nupepa Ku'oko' $a$ : A Chronicle of Entries, October 1861-September 1862. Reference Series of Hawaiian Studies, vol. 1. Honolulu: Topgallant Publishing Company, 1975. 253 pp.

Indices to articles published in newspaper: by title, subject, and author.

\section{Pacific Business News}

1909 "Firm to Publish New Business Weekly Here," S-B, February 7, 1963, I-B: 3.

Reports plans of George Mason and John Ramsey to publish weekly Pacific Business News.

\section{Paradise Magazine}

1910 “Two Publications Launched," PICN, 4, no. 3 (May 1974): 9.

Reports appearance of two new magazines, including Paradise Magazine, designed to serve Filipino community in Hawaii.

\section{Philippine-American Press}

1911 "Filipino Paper to be Published," S-B, March 23, 1960, I-B: 2.

Reports plans of Doroteo M. Collado to publish new biweekly Filipino-English tabloid, PhilippineAmerican Press.

1912 "First Edition of Filipino Paper to Go On Sale Easter Week: Sponsored by PIAmerican Goodwill Foundation," S-B, March 23, 1960, I-B: 2.

1913 “Filipino Newspaper Started," S-B, April 20, 1960, 15: 5.

Notes publication of first edition of Philippine-American Press on April 15.

\section{The Polynesian}

1914 "Reminiscences of the Press, by One of the 'Press-Gang'," Thrum's Hawaiian Annual, 3 (1877): 24-27.

Very brief history of The Polynesian and the Pacific Commercial Advertiser and criticism of both. 


\section{Portuguese-Language Newspapers}

See also names of specific publications

1915 "University Plans to Microfilm Old Portuguese Papers," $S$ - $B$, September 24, 1953, 2\%: 4.

Charles Hunter, Chairman of Department of History at University of Hawaii, seeks old newspapers to be microfilmed for historical uses; first phase of microfilming all old newspapers in Hawaii is doing the Portuguese-language papers.

1916 Knowlton, Edgar C., Jr. "The Portuguese Language Press of Hawaii," Social Process in Hawaii, 24 (1960): 89-99.

A historical sketch with a list of Portuguese-language newspapers published in Hawaii with their dates and editors; includes several pages of quotations from the papers on the issues discussed and views expressed.

1917 "Portuguese Language Resources for Hawaiian History." Hawaiian Historical Society Report, 1961, pp. 24-37.

Bibliographic essay includes discussion of attitudes toward annexation expressed in Portugueselanguage newspapers in Hawaii in 1896 and 1897.

\section{Pua Mana}

1918 “Underground Press Coming to Hawaii,” $A D V$, December 11, 1967, D-7: 2. Reports forthcoming publication of an “underground" newspaper, Pua Mana (Flower Power).

\section{Sandwich Islands Gazette}

1919 Yzendoorn, Reginald. "Establishment of the First English Language Newspaper in the Hawaiian Islands," Hawaiian Historical Society Report, 1913, pp. 17-18.

Based on entries in a journal kept by Brother Melchior Bondu.

1920 Hoyt, Helen P. “Hawaii's First English Newspaper and Its Editor,' Hawaiian Historical Society Report, 1954, pp. 5-18.

History of the Sandwich Islands Gazette and Journal of Commerce and its editor, Stephen D. Mackintosh. (Reprinted in Kokua, 19, no. 9 (July 1956): 5-18.)

\section{Sandwich Islands Monthly Magazine}

1921 Davis, Eleanor H. “Abraham Fornander and the Sandwich Islands' Monthly Magazine,"' Hawaiian Journal of History, 6 (1972): 107-28.

Reviews monthly newspaper which was published in 1856.

\section{UPW Organizer}

1922 “2 Isle Papers Labeled Party Liners,”' $A D V$, March 9, 1967, A-1: 2.

Reports charges by State Commission on Subversive Activities that the UPW Organizer and another labor union publication followed the Communist Party line.

\section{Waikiki-Kaimuki Chronicle}

1923 “'Benet Costa to Start Sunday Only Paper,'” S-B, November 1, 1947, 10: 2.

Reports plans for establishment of Honolulu Chronicle, to be published on Sundays. 


\section{West Hawaii News}

1924 Dixon, J. B. "Publication of West Hawaii News Assured," $A D V$, April 17, 1952, II-8: 3.

Describes plans of the writer and others to publish a new newspaper, West Hawaii News, twice monthly; will incorporate Dixon's Big Islander.

1925 "Its Editor Says Kona Paper is Going Strong," $A D V$, November 2, 1952, III-8: 3.

Interview with Homer Hayes, editor of West Hawaii News; discusses paper's operations during its first six months.

\section{Windward Oahu Reporter}

1926 "Californian Buys Control of Windward Reporter," S-B, April 17, 1959, 9: 4.

Reports purchase of control of Windward Oahu Reporter by Don B. Brown from Marion Sexton.

1927 “Windward Reporter Up for Sale,"' $S$-B, March 29, 1960, 27: 6.

Reports offer of sale of Windward Oahu Reporter.

1928 "Windward Reporter's Final Edition Printed; Hopes There'll Be a Buyer," $S-B$, April 23, 1960, 2: 1 .

Reports publication of final edition of Windward Oahu Reporter.

\section{Yōen jihō}

1929 "Owners Mr. and Mrs. Chinyei Kinjo Open New Plant, N. Kukui," $S$ - $B$, February 23, 1954, 16: 1 .

\section{PRESS/BROADCASTING ORGANIZATIONS}

1930 Pan-Pacific Union. First Pan-Pacific Press Conference, A Regional Section of the Press Congress of the World: Program and Proceedings. Honolulu: Honolulu Star-Bulletin Ltd., 1921. 95 pp.

Proceedings and papers of conference held October 21, 1921, in conjunction with the Press Congress of the World in Honolulu.

1931 Thrum, Thomas G. "Aloha! Press Congress, Aloha!' Thrum's Hawaiian Annual (1921): 130-39.

An account of the activities of the delegates to the Press Congress of the World in Honolulu.

1932 . "Press Congress Convention," Thrum's Hawaiian Annual (1921): 139-51.

Contains President Warren G. Harding's speech, read to the convention; address by Walter Williams; statement of aims of the convention; list of delegates.

1933 Rodriguez, Virgilio B. "World Peace Ideal of Press Congress," Editor \& Publisher, 54 (September 24, 1921): 5-6, 40.

Describes plan of Honolulu meeting as formation of a permanent organization of journalists for better international understanding.

1934 Farrington, Wallace R. "The Press Congress and Its Significance," The Friend, October 1921, p. 229.

Article stresses relationship between Hawaii's multi-cultural environment and the Press Congress. 
1935 “The Press Congress of the World," Bulletin of the Pan-American Union, no. 53 (November 1921): 485-89.

Program and highlights of the Press Congress of the World held in Honolulu.

1936 “"Ethics and Understanding Press Congress Aim," Editor \& Publisher, 54 (December 3, 1921): 5 .

1937 "Pan-Pacific Unity and Committee's High Accomplishments-Williams," Editor \& Publisher, 54 (December 3, 1921): 7-9.

1938 “Hawaii Claims Front Rank Position in Use of Press for Congress," Editor \& Publisher, 54 (December 3, 1921): 12.

1939 “Community Council Suggested to Help Screen TV Shows," $S-B$, March 12, 1953, C-2: 1.

Reports Parent-Teacher Association meeting to discuss establishment of a TV council.

1940 “'Educational TV Report is Asked by King,"' $A D V$, July 30, 1953, 8: 2.

Discusses proposed creation of council on ETV.

1941 “"Meeting to Organize TV Foundation," $A D V$, October 11, 1954, A-8: 1.

Lists members of Educational TV Foundation of Hawaii.

1942 “'Educational TV Group Names Garth Chairman,"' $A D V$, November 4, 1954, A-11: 1 .

Reports new group developed from the Territorial Council on Educational Television; Arthur Garth elected Chairman; goal is to increase educational programs on commercial channels.

1943 “"Educational TV Station is Dream of Foundation," $S-B$, November 17, 1954, 46: 4.

Reviews difficulties in pursuing goals of Educational TV Foundation.

1944 “Papers Form 1st Association,” $A D V$, January 11, 1964, A-7: 1.

Reports formation of Hawaii Newspaper Publishers Association, selection of Ezra Crane, Maui News editor, as temporary chairman.

1945 “'Enlarge Fields, Publishers Told," $A D V$, October 7, 1967, A-2: 2.

Report of fourth annual meeting of Hawaii Newspaper Publishers Association.

1946 “'Honolulu News Association Formed," PICN, 2, no. 1 (February 1971): 6.

Brief note on formation of Hawaii Newsmen's Association.

1947 Hostetler, Harold. “'Requiem for a Good Idea," Hawaii Journalism Review, 2, no. 3 (March 1972), not paged.

Review and critical appraisal of the defunct Newsmen's Association of Hawaii.

1948 Kashiwahara, Ken. “CCA Nixes Fasi, McClung Shows," Hawaii Journalism Review, 2, no. 3 (March 1972), not paged.

President of the Capitol Correspondents' Association discusses the organization's position on "canned" news conferences held by two mayoral candidates. 


\section{PRESS COUNCILS}

1949 "Conference to Study News Media Quality," $A D V$, December 10, 1969, C-20: 3.

Newly formed Community News Media Committee, headed by the Rev. Claude DuTeil, will hold conference to study ways of bringing news media and the community closer together. Feasibility of starting a community press council will be discussed.

1950 "Community-Media Council Establishes Its 'Identity',' $A D V$, November 17, 1970, A-10: 1.

Reports first meeting of council.

1951 Kaser, Tom. "To the Media, Fair's Fair Though Some May Disagree," $A D V$, November 17, 1970, A-10: 5.

Presents 1970 election coverage problems which were reviewed at newly established CommunityMedia Council.

1952 Richstad, Jim. "Community-Media Panel Here Unique," $A D V$, November 17, 1970, A-10: 1-2.

Executive director of the Council reviews its formation, guidelines, purposes.

1953 “News Media Council Active in Honolulu," Editor \& Publisher, 103, no. 48 (November 28, 1970): 30.

Reports formation of Honolulu Community-Media Council; statement of purpose.

1954 “'Editors Deny Bias in News," $A D V$, May 27, 1971, A-15: 5.

Article reviews Honolulu newspaper editor's remarks about charges that Honolulu Community-Media Council made concerning problems in reporting news accurately or without bias.

1955 Hunter, Gene. "Visiting Editor Says All Forms of Media Need Improvement," $A D V$, July 16, 1971, B-8: 1 .

Reviews remarks of Alfred Balk, in Honolulu to study activities of Honolulu Community-Media Council, while writing paper for 20th Century Task Force on Press Councils.

1956 Rivers, William L. “" 'Who Shall Guard the Guards',” The Progressive, 35, no. 9 (September 1971): 23-28.

Discusses function of press councils, with special attention to Honolulu media council.

1957 Jones, Bob. “Media Council Aloof?" Hawaii Journalism Review, 1, no. 7 (November 1971), not paged.

Discusses failure of Honolulu Community-Media Council to act on a complaint accusing Honolulu's two major newspapers of improperly lobbying in behalf of the Hawaii Newspaper Preservation Act.

1958 Rivers, William, William B. Blankenburg, Kenneth Starck, and Earl Reeves. Backtalk: Press Councils in America. San Francisco: Caulfield Press, 1972. 146 pp. Includes a section on the Honolulu Community-Media Council.

1959 Smyser, A. A. "Sizing Up the Media Council," S-B, February 1, 1972, A-23: 2.

A review of the activities of the Honolulu Community-Media Council after more than two years; assesses its impact and value; describes five cases; written by the editor of the Honolulu Star-Bulletin. 
1960 Balk, Alfred. A Free and Responsive Press. New York: Twentieth Century Fund, 1973.

Contains a discussion on pages $46-55$ of the Honolulu Community-Media Council, tracing its development during its first two years, describing the complaint procedure and important cases, and assessing its future.

1961 Honolulu Community-Media Council. "Statement of Purposes." Adopted January 30, 1973, Honolulu. 14 pp.

Basic organizational document for media council; lists purposes, functions and procedures, committees, membership and other policy matters, under 1973 re-structuring.

1962 Hamilton, Thomas. "The Media Council-What Now?" Hawaii Journalism Review, 2, no. 8 (April 1973): 4.

Council chairman reviews brief history of Honolulu Community-Media Council.

1963 Grimes, Paul. "Honolulu: Trials of a Media Council," Columbia Journalism Review, 12, no. 1 (May-June 1973): 59-61.

A critical review of the workings of the Honolulu Community-Media Council during its first two and one-half years; includes a summary of the impressions of an evaluation committee, of which the writer was a member.

1964 Richstad, Jim. "A Review of Some Matters Brought Before the Honolulu Community-Media Council." Report to Honolulu Community-Media Council, Honolulu, May 22, 1974. 9 pp.

Review of handling of several major cases by the media council, and summary of other matters.

1965 "Report on Honolulu Community-Media Council." Honolulu.

September 4, 1974. $7 \mathrm{pp}$.

Review of first four years of council, by executive director.

1966 Carmichael, Dan. "Frank Fasi and the Press: The Clash of Power," Senior Thesis, University of Hawaii, 1975. 108 pp.

Examines charges made against Honolulu newspapers by Honolulu Mayor Frank F. Fasi's campaign committee to the Honolulu Community-Media Council; campaign committee complained of unfair treatment in newspaper coverage of 1974 primary election campaign.

1967 Richstad, Jim. "Press Councils: Emerging Forms of Media Criticism and Accountability."' Paper Prepared for Association for Education in Journalism Convention, Ottawa, August 16-19, 1975. 33 pp. Appendices.

Reviews press and media councils and means by which councils can have an impact on community news service. Honolulu Community-Media Council examples extensively used in paper by executive director.

1968 "Honolulu Community-Media Council," entry for Hawaii Encyclopedia. Ed. Robert L. Scott. Honolulu: University Press of Hawaii. (In press).

History of media council since founding in 1970; reviews procedures, chairmen, staff, main concerns, and cases before council.

\section{PRINTING}

1969 Notice. Done at Woahoo, This 8th Day of March, 1822. Redone by Charles Adams, Frances Jackson, and David Kittelson, March 8, 1972. Honolulu, Hawaii. 4 pp.

History, description and facsimile of the first Hawaiian printed law. 
1970 “Press at Honolulu,” Hawaiian Spectator, 1, no. 2 (April 1838): 93-4.

Lists periodicals in either Hawaiian or English languages published in Honolulu.

1971 Dibble, Sheldon. History of the Sandwich Islands. Lahainaluna: Press of the Mission Seminary, 1843. 464 pp. Reprinted, Honolulu: T. G. Thrum, 1909.

Some information on early printing and first Hawaiian-language periodicals.

1972 Bingham, Hiram. A Residence of Twenty-One Years in the Sandwich Islands. Hartford, Connecticut: H. Huntington, $1847.616 \mathrm{pp}$.

Chapter 7 describes the introduction of a written Hawaiian language and early missionary printing; chapter 19 discusses missionary printing activities and the introduction of The Hawaiian Luminary (1834), a mission seminary newspaper.

1973 Hunnewell, James P. "First Printing at the Hawaiian Islands," Hawaiian Club Papers. Boston: Press of A. A. Kingman, 1868. pp. 38-40.

Reviews earliest printing in Hawaii.

1974 Westervelt, W. D. "Hawaiian Printed Laws Before the Constitution," Hawaiian Historical Society Report, 1908, pp. 39-51.

Reviews earliest printing and printed laws in Hawaii.

1975 "'The Printing Press of the Mission Under Mr. Loomis," Thrum's Hawaiian Annual, 35 (1909): 106-115.

History of early printing in Hawaii.

1976 “Centennial of Printing in Hawaii,” The Friend, January 1922, pp. 8-9.

Brief history of printing in Hawaii and speculation over whether the first printing in the Pacific was done by Elisha Loomis in Honolulu or in Tahiti.

1977 Ballou, H. M., and G. R. Carter. "History of the Hawaiian Mission Press,'” Hawaiian Historical Society Report, 1923, pp. 9-44.

1978 Weiss, David. “Printing in Hawaii: From Missionaries' Type Puzzle to Present Day Triumphs and Troubles,' Paradise of the Pacific, 37, no. 6 (June 1924): 20-21.

Brief history of printing in Hawaii with comments by the writer on why he finds the work of printers in Hawaii inferior to that done in the mainland United States.

1979 Yzendoorn, Reginald. History of the Catholic Mission in the Hawaiian Islands. Honolulu: $S-B, 1927.254$ pp.

Some history of Catholic press and early Hawaiian-language, religious periodicals.

1980 “'Lithography in Hawaii,"' The Sales Builder, 5, no. 8 (August 1934): 3-18.

Describes the economics, operations, and facilities of the lithography department of the Star-Bulletin Printing House, with samples of its work.

1981 “'Bashful Bride,” The Sales Builder, 7, no. 5 (May 1935): 11-14.

Half-tone and photo engraving at the Honolulu Star-Bulletin.

1982 Lockley, Fred. “Oregon's First Printing Press Brought From Hawaii,” $S$ - $B$, October 1, 1940, 3: 2.

Discusses early printing in Hawaii and transfer of press to Oregon for use by missionaries. 
1983 "Biblio-poesy-phily and -pole," The Sales Builder, 14, no. 6 (June 1941): $2-15$.

Describes some early printing activities in Hawaii.

1984 The Hawaiian Bible and Other Early Printing in the Islands. Honolulu: Honolulu Club of Printing House Craftsmen, 1949. 62 pp.

Reviews earliest religious printing in Hawaii.

1985 Stenberg, Ernest W. "The Honolulu Club of Printing House Craftsmen," Kokua, 8, no. 7 (September 1949): 13, 15, 17.

From a July 1948 talk on the history of the club.

1986 Taylor, Clarice. "50 Years of Printing-and Some of the Early Printers," Kokua, 8, no. 7 (September 1949): 28-29.

1987 "Giant Press to be Fastest in the Territory," $S-B$, October 29, 1949, 3: 1.

Describes new press installation planned for the Star-Bulletin.

1988 Day, A. Grove. “Ka Palapala Hemolele,” Kokua, 8, no. 9 (November 1949).

Reviews early printing in Hawaii.

1989 Hogue, Charles E. "Vanishing Printing Presses," $A D V$, October 17, 1950, 6: 3.

Discusses researchers' attempts to learn the disposition of early presses used in Hawaii.

1990 Loomis, Albertine. Grapes of Canaan: Hawaii 1820. New York: Dodd, Mead, 1951. 334 pp. Reprinted, Honolulu: Hawaiian Mission Children's Society, 1966, 1967, 1969.

A documentary novel based on the journals of Elisha Loomis, missionary printer.

1991 “300 Ton Press Is Ready: It Can Turn Out 40,000 Papers an Hour," $S-B$, January 31, 1951, 23: 3.

Describes press newly installed at Star-Bulletin.

1992 "Historic Press Once Used by Star-Bulletin's Predecessor," $S-B$, January 31, 1951, 24: 1 .

Brief sketch of early printing and presses in Hawaii.

1993 Day, A. G. "Pioneer Presses of Hawaii," Journal of the American Institute of Graphic Arts, 4, no. 5 (1952): 33-40.

1994 Smith, Lawrence R. "Engraving in Hawaii," Kokua, 16, no. 2 (October 1952): 1-2; 16, no. 3 (November 1952): 2.

Describes developing use of engraving in Hawaii publications.

1995 Wise, C. M. and W. D. Hervey. "The Evolution of Hawaiian Orthography," Quarterly Journal of Speech, 38, no. 3 (October 1952): 311-25.

Article about Hawaiian and Polynesian languages includes history of early printing and periodicals in Hawaii.

1996 Boyer, Jack. "Creative Typography is Hobby of This Program," $A D V$, January 25, 1953, II-6: 1.

Describes the avocational printing enterprise of A. Grove Day, the White Knight Press. 
1997 Julich, Reinhold W. “Elisha Loomis, Hawaii's First Printer," Kokua, 16, no. 5 (January 1953): 3-8.

Describes Loomis's printing activities.

1998 Jardin, M. G. “Commercial Printing in Hawaii Since 1900," Kokua, 16, no. 6 (February 1953): 4-8; 16, no. 7 (March 1953): 4-7; 16, no. 8 (April 1953): 5-8; 16, no. 10 (June 1953): 5-8.

An account of the development of commercial printing in Hawaii in four installments, 1900-1918, 1919-1941, 1942-1945, and 1946-1952.

1999 Day, A. Grove. "The First Printers of Hawaii," Paradise of the Pacific, 67, (Annual edition, 1955): 33-36, 101.

Historical accounts of early printers, primarily Elisha Loomis. Description and use of early publications, including several reproductions.

2000 Dutton, Meiric K. Final Years of the Sandwich Islands Mission Press, Including a Brief Sketch of Its Assimilation by Henry M. Whitney's Advertiser Press. Honolulu: Loomis House Press, 1956. 9 pp.

2001 Hoyt, Helen P. "The Sandwich Islands Story of California's First Printing Press," California Historical Society Quarterly, 35, no. 3 (September 1956): 192-204.

2002 "137-Year History of the Commercial Printing Division of Advertiser Makes It Oldest Business in Hawaii,"' $A D V$, June 23, 1959, I-36: 1.

2003 Spaulding, Thomas M. "The First Printing in Hawaii," Papers of the Bibliographical Society of America, 50, no. 4 (1956): 313-27.

2004 Howell, Beatrice. "Hawaii, Pioneer of Far Western Printing," Royle Forum, June 15, 1963, pp. 1-6.

2005 "Isles Printing Trade Began With One Press," $S B A$, January 17, 1965, A-17: 1.

Describes first printing press in Hawaii, operated by missionaries.

2006 Windley, Larry. “Lahainaluna Printing," Hawaii Historical Review, 2, no. 2 (January 1966): 257-87.

Brief account of early missionary printing activities at Lahainaluna and a preliminary list of works printed there from 1834 to 1846 .

2007 "Lahainaluna Engraving," Hawaii Historical Review, 2, no. 3 (April 1966): 290-96.

History of engravings for printing done at Lahainaluna and a list of engravings made there.

2008 “Fete for a Book, a Press, an Anniversary," $A D V$, January 5, 1967, B-1: 1.

Describes exhibition of replica of Ramange press, first press in Hawaii.

2009 "First Thing Printed Here Was 16-Page Spelling Book," $S$ - $B$, January 6, 1967, A-6: 3.

Full-page article on National Printing Week; describes artifacts of Albertine Loomis, great- granddaughter of Elisha Loomis, Hawaii's first printer. 
2010 “'When Printing Came to Hawaii,” $S-B$, January 7, 1967, A-4: 1.

Editorial describing development of printing in Hawaii; concentrates on newspaper production.

2011 "New Pages for Press History," SBA, January 8, 1967, A-2: 3.

One of a series of articles on National Printing Week; focuses on printing in Hawaii; describes reenactment of first page struck.

2012 "Ad Man and Teachers Recreate Hawaii's First Presses," Inland Printer/American Lithographer, 159, no. 3 (June 1967): 70.

Describes a project to construct replicas of an early wooden press of the type brought to Hawaii.

2013 Schmitt, Robert C. "Notes on Hawaiian Photography Before 1890," Hawaiian Historical Review, 2, no. 9 (October 1967): 409-16.

Some references to early use of photographs in Hawaii publications.

2014 Apple, Margaret. "Early Printers and Printing in Hawaii," Hawaii Library Association Journal, 25, no. 2 (December 1968): 3-10.

Reviews missionary press in Hawaii and earliest missionary and commercial periodicals; plus history of other long-established newspapers.

2015 Day, A. Grove and Albertine Loomis. Ka Pa'i Palapala: Early Printing in Hawaii. Honolulu: Printing Industries of Hawaii, 1973. 36 pp.

Short history of early missionary and commercial printing activities in Hawaii.

2016 Kittelson, David. "Early Printing Here," $A D V$, February 11, 1972, A-25: 1. Production statistics of the early missionary press.

\section{RADIO BROADCASTING \\ General}

2017 “Wailuku Hears Georgia Radio," NYT, December 27, 1922, 8: 3.

Reports reception at Wailuku, Maui, of broadcast from radio station WSB, Atlanta.

2018 “Advertiser Gives Its First Radio Program," ADV, May 12, 1922, 1:7; rpt. February 24, 1976, Great Moments ed., III-1:2.

Lengthy description of the first broadcast of station KGU. Advance stories appeared on page one of the Advertiser on May 9,10, and 11; the pioneer broadcasts continued to receive front-page treatment in the paper for several days after May 12.

2019 Mulrony, M. A. "Radio in Hawaii," Thrum's Hawaiian Annual (1929): 66-69.

Brief history of Trans-Pacific radio communication in Hawaii; government and commercial transmitting and receiving sites described.

2020 "Hams in Your Air," The Sales Builder, 13, no. 4 (April 1940): 2-15.

Popularized history of radio and telegraphy in Hawaii.

2021 Lambeth, Harry J. "Hawaii Calls," The New Pacific, 3, no. 4 (April 1945): 8-9.

Describes development of radio program titled "Hawaii Calls" during its first ten years; also discusses similar program "Voice of Hawaii." 
2022 United States. Congress. Senate. Committee on the Judiciary. Scope of Soviet Activity in the United States. Hearings before the Subcommittee to Investigate the Administration of the Internal Security Act and other Internal Security Laws. 84 Congress, 2nd Session, part 39-41-A, November 16, 30, December 1, 3-6, 1956. Washington: Government Printing Office, 1957.

Reviews activities of newspapers, International Longshoremen's and Warehousemen's Union radio broadcasts, etc., and their alleged un-American influences.

2023 Thurston, Lorrin P. "Communism Does Not, and Never Will, Control Hawaii." Honolulu: Hawaii Statehood Commission, 1957. 10 pp.

The chairman of the Hawaii Statehood Commission argues that an allegedly communist newspaper, the Honolulu Record, and radio broadcasts of the International Longshoremen's and Warehousemen's Union have no significant influence.

2024 "How to Buy Broadcast Advertising in Hawaii," Broadcasting, 58, no. 3 (January 18, 1960): 73-74, 77-78.

Describes radio and television coverage, market characteristics, and programming patterns.

2025 "The Real Magic of the Islands," Broadcasting, 58, no. 3 (January 18, 1960): 67-70, 72-73.

A general feature on Hawaii and its social and economic climate; includes list of radio and television stations in operation.

2026 “'Radio-TV Set Counts,” Broadcasting, 62, no. 4 (January 22, 1962): 90.

Tabular data on radio and television sets in use in Hawaii.

2027 “'One of Isle's Real Radio Veterans," $S B A$, May 25, 1969, Aloha Magazine, p. 6.

Feature article on Paul Wilcox.

2028 Simpich, Frederick, Jr. Anatomy of Hawaii. New York: Coward, McCann \& Geoghegan, 1971.284 pp.

Hawaii's mass media reviewed in chapter 7 .

2029 “'KFOA Now KUMU; KGU to Air 'Lights Out'," $S-B$, August 18, 1971, E-8: 2.

Article updates changes at many Honolulu radio stations.

2030 Youngblood, Ron. "Ripping Off the News," Hawaii Journalism Review, 1, no. 6 (October 1971), not paged.

Chastises broadcasters for relying on news items lifted directly from local newspapers.

2031 Coffman, Tom. To Catch A Wave: Hawaii's New Politics. Honolulu: Honolulu Star-Bulletin, 1972. 219 pp. 2nd edition: The University Press of Hawaii, 1973, $211 \mathrm{pp}$.

An account of the 1970 Hawaii gubernatorial election campaign; contains material on the use of mass media in the campaign.

2032 "The Rival Radio Race of Honolulu," SBA, May 14, 1972, Aloha Magazine, p. 5.

Brief radio history beginning in 1922. 
2033 “Hawaiian Music Largely Ignored by Island Radio," $S$ - B, June 26, 1972, B-5: 1.

Rundown of radio stations which do and do not include Hawaiian music in their programming.

2034 Mayer, Phil. "He's Got Us All Wired for Sound," S-B, August 27, 1974, D-8: 1.

Reviews career of Allen Roycroft who is Chief Engineer for 13 AM and 2 FM radio stations and one TV station in Honolulu.

2035 “' 'Hawaii Public Radio'-A Recommendation for '75,” S-B, February 22, 1975, A-8: 1.

A new public radio network was proposed to the Legislature, to be complete by 1979.

2036 “Oahu's 21 Radio Stations," S-B, February 22, 1975, A-11: 1.

A look at the public record files for Oahu's commercial stations.

2037 Lueras, Leonard. "Island Broadcasters Target of Complaints," $A D V$, March 19, 1975, D-1: 1 .

Reviews complaints and recommendations FCC received about island radio stations or disc jockeys. A sub-article titled "Stations Report Improvements" reports that radio stations say they have corrected the complaints that FCC aired.

2038 “More Classical, Hawaiian Music Wanted," S-B, December 2, 1975, B-12: 1. Reviews survey on radio programming.

2039 Gereben, Janos. "Many Changes in Radio," S-B, February 12, 1976, D-8: 1. Second annual survey of Oahu's radio stations (now 21). Table provides information on each station's: program format, employees, percentage of commercials per hour, number of public announcements per week, etc. Author calls Honolulu's radio broadcasting "a wasteland." Article reviewed in Pacific Islands Communication Newsletter, 6, no. 1 (March 1976): 8.

\section{Foreign-Language Broadcasting}

2040 Silva, Ernest. "Foreign Language Broadcasts," The New Pacific, 2, no. 12 (December 1944): 7-8.

Short description of Filipino broadcasts in Hawaii at time of writing.

2041 Hollinger, Fin. "Should We Have Japanese Language Radio Programs in Hawaii?" Paradise of the Pacific, 65, no. 5 (May 1953): 28-29, 33.

The general manager of a Honolulu radio station argues that Japanese-language programs are important to Hawaii's Japanese population.

2042 Klopf, Donald W. and John P. Highlander. "The Radio Obituary: Cultural Phenomenon in Broadcasting," Journalism Quarterly, 41, no. 3 (Summer 1964): 440-42.

Describes development and content of commercial obituary notices on Hawaiian Japanese-language radio stations, $\mathrm{KOHO}$ and $\mathrm{KZOO}$.

2043 Highlander, John P. and Donald W. Klopf. "Hawaii's Broadcasters Offer Programs in Several Languages," NAEB Journal, 24, no. 3 (May-June 1965): 22-28.

A study of foreign-language broadcasting in Hawaii based on interviews and questionnaires on ethnic and foreign-language programming, analysis of program schedules, and spot checks of broadcasts; includes data on extent and content of such programming in Japanese, Filipino, Chinese, Okinawan, Samoan, Korean, Puerto Rican, French, and German. 
2044 Klopf, Donald W. and John P. Highlander. "Foreign Language Broadcasting in the Western States," Western Speech, 29, no. 4 (Fall 1965): 219-27.

Reports over 340 radio and TV stations broadcast foreign-language programs; of these almost half are in 13 Western states, including Hawaii.

\section{$K A H U$}

2045 “FCC Fines Isle Station," S-B, September 23, 1971, D-9: 1.

Reports Waipahu radio station KAHU fined for not treating political candidates uniformly in advertising rate charges.

2046 "KAHU Sold for $\$ 500,000, " S-B$, August 8, 1975, A-6: 3.

Reports W. Russell Withers Jr. purchase of KAHU, Waipahu, and the construction permit for KULA-FM.

2047 Maneki, Roy. "KAHU is Going FM," S-B, December 18, 1975, C-1: 1. Reviews staff and programming of radio station KAHU.

\section{$K C C N$}

2048 Amalu, Sammy. "A Tip of the Hat to KCCN," $A D V$, November 2, 1971, C-7: 2 .

Sammy Amalu's column praises KCCN's personnel and promotion of Hawaiian music.

\section{$K G M B$}

2049 "'Star-Bulletin Begins Hourly News Broadcasts,"' $S$ - $B$, May 31, 1945, 1: 1.

Announces expansion of news broadcasting on station KGMB.

2050 "'Honolulu Group Buys Star-Bulletin Control," Editor \& Publisher, 94, no. 47 (November 25, 1961): 15.

Reports sale of majority stock in Honolulu Star-Bulletin and its broadcast facilities by the trustees of the W. R. Farrington Estate to a group of Honolulu businessmen; includes KGMB-AM-TV, Honolulu; KHBC-AM-TV, Hilo; KMAU-TV, Wailuku.

2051 "Sale Closing in Honolulu Set April 30," Editor \& Publisher, 95, no. 13 (March 31, 1962): 13.

Reports plans for formal signing of contract for sale of Honolulu Star-Bulletin and its broadcasting stations; date set after FCC approval of license transfer of the stations, KGMB-AM-TV, Honolulu; KHBC-AM-TV, Hilo; KMAU-TV, Wailuku.

2052 "Star-Bulletin Passes to Hawaii Syndicate," Editor \& Publisher, 95, no. 18 (May 5, 1962): 11, 60.

Reports completion of sale of Honolulu Star-Bulletin and its broadcast properties, KGMB-AM-TV, Honolulu; KHBC-AM-TV, Hilo; KMAU-TV, Wailuku.

2053 "Third Honolulu Sale Gets FCC Approval," Broadcasting, 68, no. 19 (May 10, 1965): 54.

Reports FCC approval of sale of Honolulu Star-Bulletin stations KGMB-AM-TV, Honolulu, KHBCAM-TV, Hilo, KMAU-TV, Wailuku; notes earlier sale of KHVH-AM-FM by Henry J. Kaiser to Lawrence S. Berger.

2054 “'KGMB Going FM April 1," SBA, March 3, 1968, Magazine Section, 1: 1.

KGMB becomes fourth FM station in Hawaii. 
2055 “'Radio Station Target of Union Action," $A D V$, October 7, 1971, B-7: 1.

The American Federation of Television and Radio Artists (AFTRA) filed unfair labor practices charges against KGMB.

2056 “'Heftels Become Sole Owners of KGMB, KPUA," $S$ - B, February 26, 1972, A-6: 3.

Cecil L. Heftel and his wife Joyce are sole owners of radio and TV station KGMB, Honolulu and KPUA, Hilo.

2057 Borsch, Fred. "Islanders Tune in KGMB for Long-Term Radio Pact," $A D V$, September 10, 1974, D-1: 3.

Hawaii Islanders team and KGMB announced contract for broadcasting the 1975 season's sports coverage.

2058 "Radio Station Sued for Slander," $A D V$, June 17, 1975, A-10: 1.

Heftel Broadcasting Corporation, owner of radio station KGMB, and KGMB disc jockey, sued in slander suit.

\section{$K G U$}

2059 "Islands in the Pacific Want Network Tie-up," NYT, September 13, 1931, $\mathrm{X}-15: 3$.

Radio stations in Hawaii reported seeking means to join mainland U.S. radio networks for regular service; a representative of KGU reported in New York for discussions.

2060 "Honolulu Back on Air," NYT, December 15, 1941, 4: 7.

Reports resumption of broadcasting by radio station KGU on December 14, having been silent since December 7 attack on Pearl Harbor.

2061 “KGU Island's First Station to Sign Pact with Union," $A D V$, May 1, 1969, A-2: 1 .

KGU and the American Federation of Television and Radio Artists (AFTRA) announce Honolulu's first collective bargaining agreement for radio performers.

2062 "KGU's Year-'round Sports Season," $S B A$, August 16, 1970, Aloha Magazine, 51: 1.

KGU concentrates programming on sports.

2063 “'KFOA Now KUMU; KGU to Air 'Lights Out',"' $S$ - $B$, August 18, 1971, E-8: 2.

Article updates changes at KGU.

2064 "'Metzger to be KGU President,"' $A D V$, March 7, 1974, F-7: 6.

John Walton Enterprises of El Paso will buy KGU from the Copley Press, Inc. after FCC approval; Don Metzger has been named president.

\section{KHAI}

2065 “Renewal Favored on Diversification," Broadcasting, 73, no. 1 (July 3, 1967): 45.

Reports FCC hearing examiner's recommendation that renewal of license of KHAI, Honolulu, be granted to Royal Broadcasting Co. over challenge by Radio KHAI, Inc.

2066 "Station KHAI Off the Air," S-B, January 1, 1971, C-10: 4.

KHAI folded for lack of financial backing. 


\section{KHSS-FM}

2067 Harada, Wayne. "KHSS is Radio-active," $A D V$, March 21, 1974, C-9: 1.

Hawaii's fifth FM radio station started operations with plans for 24-hour programming.

\section{$\mathrm{KHVH}$}

2068 "F.C.C. Okays Kaiser Television Station: Islands Will Get Color TV Soon," $S-B$, April 8, 1957, A-1: 6.

KHVH-TV has permission to operate but $\mathrm{KHVH}$ radio station has been ordered to stop pending an FCC investigation into charges that ten radio stations in Honolulu are "too much."

2069 "The Wonderful World of Henry J. Kaiser," Broadcasting, 58, no. 3 (January 18, 1960): 82.

Feature story on Kaiser, owner of KHVH and KHVH-TV.

2070 "KHVH-Radio for Sale," $A D V$, May 5, 1971, B-1: 3.

Western Telestations is selling KHVH-Radio to KHVH president and Western Telestations majority stockholder, Lawrence S. (Bob) Berger.

2071 "Berger Firm Gets Samoa Station: Commercial Radio," $A D V$, April 23, 1973, A-14: 1.

Radio Samoa, Inc., an organization headed by general manager of KHVH-TV, signed contract for taking over operation of WVUV, American Samoa's radio station.

2072 "Radio Station Sets Move to New Site," $S-B$, June 25, 1973, A-17: 1.

KHVH moving to new site in Honolulu. Article reports recent sale of KHVH-TV.

2073 "Radio for Samoa," S-B, March 5, 1975, A-18: 1.

Editorial reviews ties between Hawaii and American Samoa that would be strengthened by radio station WVUV, which has just received FCC approval to operate.

\section{KIKI}

2074 Engle, Murray. "The Show Nobody Sees," S-B, August 30, 1973, F-1.

Reviews how Ron King, disc jockey for KIKI, gets his radio program organized.

2075 “KIKI Now Has a Hawaii Owner," S-B, October 24, 1974, A-14: 1.

Announces a Hawaii corporation headed by $\mathrm{C}$. C. Lawrence has become owner of KIKI radio station.

\section{$K I P A$}

2076 “KIPA Power Hike Approved," $A D V$, September 27, 1975, A-20: 1.

KIPA radio in Hilo will become the first station to produce island-wide coverage as a result of new transmission power.

\section{KISA}

See also Foreign-Language Broadcasting

2077 "All Filipino Radio Station, KISA, Begins Broadcasting," $A D V$, April 27, 1973, C-11: 3.

Reviews history and management of KISA.

2078 "Tunes in to Her Heritage," $A D V$, January 2, 1974, C-1: 3.

Feature on KISA, "first and only Filipino radio station in U.S.," which began broadcasting in April, 1973. 


\section{$K K U A$}

2079 "New Island Firm Purchases KKUA," $A D V$, June 6, 1970, A-8: 1.

K(O)KUA Radio One Corporation purchased KKUA from Hercules Broadcasting Company.

\section{KLEI}

2080 " 3 Chicagoans Seek to Get KLEI Radio," $S-B$, October 6, 1970, E-2: 1.

Chicago men planning to do business in Hawaii as Hawaiian Business News Ltd. have asked the FCC for permission to take over the KLEI radio license.

2081 “KLEI Changes Hands," $S$ - $B$, February 3, 1971, E-4: 3.

Reports purchase of KLEI Radio in Kailua by Fred Livingston of Chicago.

2082 Bowman, Pierre. "Station Finds a Niche . . " S-B, June 19, 1975, C-8: 1.

Reviews KLEI programming.

\section{KORL}

2083 “FCC Taking Aim at 'Topless Radio'," $A D V$, March 16, 1973, D-5: 1.

Article reviews official criticism of "sex-talk" radio shows.

2084 "Little Ado About Sex, KORL Manager Says," $A D V$, March 16, 1973, D-5: 1.

Station manager says KORL doesn't dwell on sex as its only topic.

\section{KPOI}

2085 'Moffatt Quits Job at K-POI,"' $A D V$, March 2, 1974, A-5: 1.

Tom Moffatt, Vice President and General Manager, quits K-POI.

2086 “Purchase of K-POI Complete," $A D V$, March 19, 1974, D-7: 6.

Communico, Inc., of Hartford, Connecticut, has purchased K-POI and appointed new general manager.

2087 Fujii, Jocelyn. "It's Wolfman Jack!" S-B, December 16, 1974, B-1: 1.

Reviews career of disc jockey at K-POI.

2088 “K-POI Slapped for Contests by the FCC," $S-B$, September 12, 1975, A-2: 6 .

Reports FCC has granted a shorter license renewal to K-POI and criticized station for contests geared to increase audiences.

2089 Burrell, Shelley. "K-POI, IMC in 'Consent' on Gift Book," $A D V$, December 20, 1975, A-9: 1 .

Announcement that K-POI "gift books" that were criticized by purchasers can be returned for refund.

\section{KPUA}

2090 "Heftels Become Sole Owners of KGMB, KPUA," $S$ - $B$, February 26, 1972, A-6: 3.

Cecil L. Heftel and his wife Joyce are sole owners of radio and TV KGMB, Honolulu, and KPUA, Hilo. 
2091 “New Ownership for Hilo Station," S-B, October 15, 1975, A-12: 1.

Reports new owner for KPUA in Hilo.

\section{KTRG}

2092 Hunter, Gene. "It's the Voice of the Multitude," $A D V$, April 21, 1968, A-10:1.

The first of a six-part series of articles discussing the all-talk format of KTRG; emphasizes content of phone calls and personalities employed by station. Subsequent articles in the series appeared April 22 (A-4:4), April 23 (A-6:5), April 24 (A-11:1), April 25 (A-12:1), and April 26 (E-1:1).

2093 "Anti-KTRG Complaints Considered," $A D V$, September 19, 1969, A-8: 1.

FCC considering matter of "personal attack" and "fairness doctrine" complaints lodged against KTRG.

2094 “'FCC Orders Hearings on License for KTRG," S-B, March 3, 1970, A-2: 5.

FCC launched full-scale investigation concerning complaints against station KTRG.

2095 "FCC Division Submits 26 Allegations Against KTRG," $S$ - $B$, June 25, 1970, F-8: 1 .

Summary of complaints against KTRG.

2096 "KTRG Off Tonight, Reprieve Unlikely," $A D V$, November 7, 1970, A-10: 3.

Facing a FCC hearing on violations, KTRG leaves the air after eight-and-a-half years.

2097 “'FCC Ponders Change in Stations' License Steps," S-B, November 16, 1970, D-6: 1.

In the wake of KTRG broadcasting termination on November 1 , in a separate action, the FCC announced a possible general rule change in procedures for denying stations licenses.

2098 "They'd Rather Switch Off Than Fight," Broadcasting, 79, no. 20 (November 16, 1970): 42.

Discusses surrender of license of KTRG in Honolulu.

\section{KTUH}

2099 "Student Radio Station Goes On Air Today," $A D V$, July 7, 1969, E-7: 1.

The University of Hawaii's student radio station, KTUH, to be aired for first time; feature on programs and goals.

2100 "Small But Beloved-That's University's KTUH," S-B, March 19, 1970, E-18: 1.

Feature on KTUH operation.

2101 "UH Radio Starts Ambitious Program," S-B, November 2, 1970, E-13: 1.

KTUH, station with the smallest budget on the island, begins new "hard thinking-and-longhair" program.

2102 "Cooling Manoa's Air Waves," $A D V$, October 16, 1972, B-2: 1.

Feature on University of Hawaii radio station KTUH.

2103 “'KTUH Budget Cut," $A D V$, July 4, 1973, C-14: 5.

University of Hawaii radio station will continue despite budget cut of about half. 


\section{$K U A I$}

2104 “ 'Right' to Broadcast Hearing Disputed on Kauai," SBA, October 3, 1971, A-14: 1 .

Dispute over the constitutional right of station KUAI to broadcast a hearing by a State regulatory agency.

2105 “'Fair Hearings,"' $S-B$, October 5, 1971, A-20: 1.

Editorial on the right to broadcast hearings controversy between KUAI and the State Public Utilities Commission.

\section{$K U M U$}

2106 “KFOA Now KUMU; KGU to Air 'Lights Out'," $S-B$, August 18, 1971, E-8: 2.

John Hutton Corp. purchased KFOA-FM from Royal Hawaiian Radiu, Inc.

2107 “KUMU Hit By NLRB Judge,” SBA, May 5, 1974, A-9: 1.

National Labor Relations Board administrative law judge said KUMU negotiated in "bad faith" with American Federation of Television and Radio Artists (AFTRA).

\section{SATELLITE COMMUNICATION}

2108 Cunningham, James. "Oahu Now has Biggest Satellite Earth Station," SBA, September 1, 1968, B-7: 1 .

Reviews new satellite ground station located at Paumalu.

2109 "Isle Telecasts Around the World, as of Next Month," $A D V$, June

7, 1969, A-14: 7 .

Article reviews conference call or telecast option of islanders when Intelsat III satellite goes into operation.

2110 "NASA Invites State to Use Satellite: UH and DOE to Coordinate," $S-B$, September 10, 1970, C-3: 1-6.

National Aeronautics and Space Administration invites Hawaii to use satellite in stationary orbit over central Pacific, if feasible program can be established.

2111 “Plans Crystalize for Hawaii Satellite," PICN, 2, no. 1 (February 1971): 1-2.

Describes early planning for PEACESAT project, including personnel, projected costs, and initial Hawaii experiment.

2112 Benson, Bruce. "Hilo-Manoa Talk Spans 23,000 Miles," $A D V$, May 21, 1971, B-1: 1 .

Reviews potential of Peacesat's inexpensive ground equipment that will assist inter-island education.

2113 Glatzer, Hal. "Hilo-Manoa Talks Reach Third of World," $A D V$, July 26, 1971, A-6: 1.

Reviews Hilo-Manoa campuses' Speech Communication 145 class use of satellite.

2114 "Pacific Network for Satellite," PICN, 2, no. 2 (August 1971): 16-17.

Describes preparations for PEACESAT terminals in Fiji and Papua New Guinea to join that at the University of Hawaii. 
2115 “UH Gets New Space Role," $S-B$, August 9, 1971, A-3: 3.

Reports assignment of frequencies to ATS-1 satellite to allow University of Hawaii to use the satellite for educational communication projects in the Pacific region.

2116 Selle, Earl A. “Little Red School House in the Sky," Beacon, 11, no. 10 (October 1971): 32-3.

Reviews early history of PEACESAT project with emphasis on technical achievements of Katashi Nose.

2117 “'Radio Link," PIM, 43, no. 3 (March 1972): 29.

Reports award of Carnegie Foundation grant for experimental satellite link between Hawaii and Fiji.

2118 "Satellite Link Between Polytechnic \& Hawaii Working Well," The Evening Post (Wellington, N.Z.), March 18, 1972.

2119 “Satellite to Unite Pacific Islands," PICN, 3, no. 1 (July 1972): 1.

Interview with John Bystrom, PEACESAT director, on future of satellite communication in the Pacific.

2120 “Lessons Swap by Satellite,” PIM, 43, no. 9 (September 1972): 26.

Background on PEACESAT project.

2121 Creamer, Beverly. "PEACESAT Has Been a Learning Experience," $S$ - $B$, October 10, 1972, A-15:1.

Article reviews history and educational exchanges going on via PEACESAT.

2122 Polcyn, Kenneth A. An Educator's Guide to Satellite Technology. Washington: Information Center on Instructional Technology, Academy for Educational Development, 1973. 99 pp.

PEACESAT Project description included.

2123 Richstad, Jim, and L. S. Harms, ed. World Communication: Population Communication, Communication Technology, Communication in the Future. Honolulu: East-West Center, 1973.96 pp.

Four articles deal with the PEACESAT project. John W. Bystrom, "The PEACESAT Project: The Approach," discusses basic assumptions in development of the system. Abelina M. Costa, "The PEACESAT Project: Telecommunication Needs of Systems of Higher Education." Paul C. Yuen, "The PEACESAT Project: Application of Communications Satellite Technology," discusses ATS-1 satellite capabilities. Katashi Nose, "The PEACESAT Project: Ground Terminal Hardware."

2124 Smith, Delbert D. Satellite Applications for Education, Culture and Development. Paris: Unesco, 1973.96 pp.

Includes brief treatment of PEACESAT project.

2125 “'Satellite Network Expands in Pacific Basin," American Libraries, 4, no. 4 (April 1973): 192-93.

General background on PEACESAT project.

2126 Hunter, Pat. "PEACESAT in New Role," $A D V$, May 24, 1973, D-2: 1.

Reviews first experimental conference via PEACESAT with public health nursing personnel in American Samoa.

2127 “Peacesat Victim of Budget Cuts," PICN, 4, no. 1 (August 1973): 1.

Note on withdrawal of state financial support for Honolulu PEACESAT terminal. 
2128 Benson, Bruce. "UH Satellite to be Stilled: Politics, Lack of Funds," $S B A$, August 12, 1973, A-1: 3.

Reviews pressures on PEACESAT project.

2129 "Search to Save UH's Satellite System," $A D V$, August 16, 1973,

A-15: 1 .

Reports operators of PEACESAT project preparing to cease operations while continuing to look for means of saving program.

2130 “Mink Asks Satellite Reprieve," SBA, September 2, 1973, A-11: 2.

Reports request of U.S. Representative Patsy Mink to head of NASA asking that the agency's decision to stop the PEACESAT project be reversed.

2131 "The Serendipity of Synchronous Satellites," Vectors Magazine, 15 (Summer/Fall 1973): 26-29.

Describes demonstration projects using ATS-1 satellite, including the PEACESAT project.

2132 Byers, Burton H. "Classroom Interaction, Satellite Interposed," Audiovisual Instruction, 18, no. 10 (December 1973): 20-23.

Reviews early classroom use of satellite instruction, conducted in June and July 1971 between two campuses of the University of Hawaii.

2133 "Radio, TV News Training Discussed on PEACESAT," PICN, 4, no. 2 (December 1973): 5-6.

Article reviews content of three PEACESAT teleconferences, with participants from New Zealand, Micronesia, Fiji and Hawaii.

2134 Bystrom, John. The PEACESAT Project (Pan Pacific Education and Communication Experiments by Satellite), University of Hawaii. Testimony of John Bystrom, Project Director, Before the (Hawaii) House Committee on Higher Education, March 7, 1974. 7 pp. Appendices.

Testimony in support of financial appropriation.

2135 “Keep PEACESAT Going," $A D V$, April 2, 1974, A-10: 1.

Editorial encourages continuation of PEACESAT Project.

2136 Bystrom, John W. "Pan Pacific Education and Communication Experiments by Satellite 1971-74: The Application of International Interactive Service Support Communication." Paper prepared for a meeting of the Royal Society of London. September 19-20, 1974. 34 pp.

The director of the Pan Pacific Education and Communication Experiment by Satellite (PEACESAT) Project surveys the development and operations of the project with emphasis on use of satellites in support of educational and social services.

2137 “News Exchange Experiment Utilizes ATS-1 Satellite," PICN, 4, no. 4 (September 1974): 7.

Describes regional news exchange program after three-month test.

2138 “Satellite News Exchange Report," PICN, 5, no. 1 (February 1975): 3-5.

Summation of a report by Ian Johnstone, former South Pacific Commission education broadcasting officer, of a 1974 PEACESAT news exchange experiment; results were generally favorable; report notes problem areas. 
2139 Bystrom, John W. The PEACESAT Project: Pan Pacific Education and Communication by Satellite. Testimony presented to the Hawaii State House Committee on Higher Education. University of Hawaii, March 1975. 8 pp. Appendices.

Documents the history and postulates the future of the PEACESAT experiment. Testimony includes purpose, facilities, activities, benefits, budget, selected viewpoints of users, and future possible applications. Chronological annotation of the experiment, conducted during 1970-75, and bibliography.

2140 Goodell, Dale. "PEACESAT for Agricultural Use," Paper prepared for the Users of PEACESAT Conference, East-West Center, Communication Institute, Honolulu, April 28-May 2, 1975. 9 pp.

Reviews University of Hawaii College of Tropical Agriculture's utilization of PEACESAT system to solve problems faced by Pacific Islands through satellite conferences. Author reviews four-year history of that Department's involvement in exchanges, including problem areas.

2141 "Hawaii and PEACESAT," SBA, May 4, 1975, H-2: 1.

Editorial reviews PEACESAT Project and its financial problems, while reviewing conferences held at East-West Center-Users of Peacesat; Communication in the Pacific.

2142 "60 Meet to Examine PEACESAT, Communication in Pacific," PICN, 5, no. 2(June 1975): 1, 7.

Summarizes Users of Peacesat Conference held at East-West Center.

2143 "Hawaii ATS-6: Telecommunication Experiment." (Preliminary.) An Application submitted to the National Aeronautics and Space Administration. Honolulu: Hawaii Research Center for Futures Study, University of Hawaii, August 20, 1975. 48 pp. Appendix.

An application for use of 1,000 hours of ATS-6 satellite time for year three of the experimental program. Contains 34 experiments involving government delivery of service, citizen involvement, education and health. Focus on use of satellite communication in multi-cultural island state.

2144 “Satellite news," PICN, 5, no. 3 (September 1975): 2.

State of Hawaii intends to propose experiments on the ATS-6 satellite in its third year of operation.

2145 Richstad, Jim. "PEACESAT: Sharing by Satellite," Communication in the Pacific, Daniel Lerner and Jim Richstad, eds. Honolulu: East-West Communication Institute, June 1976. pp. 73-83.

Reviews history of PEACESAT with emphasis on East-West Communication Institute participation.

2146 Bystrom, John. "Peacesat Experiment General Description 1971-1976," Educational Broadcasting International, 9, vol. 3 (September 1976): 103-7.

Reviews PEACESAT Project history and projects, with special emphasis on health and medical education exchanges.

2147 Bystrom, John. "A Satellite Communication System: Global Development and Cultural Imperialism," Paper prepared for proceeding of Fair Communication Policy Conference, East-West Center, Communication Institute, Honolulu, March/ April 1976. In New Perspectives in International Communication. Honolulu: EastWest Communication Institute, March 1977, pp. 149-79.

Reviews changes needed toward development of a global communication system in support of world development; information on current inadequate telecommunication structures. Reviews PEACESAT Project experiments, specifications and activities as model of practical telecommunication system for developing and isolated regions. Argues why PEACESAT model is not "imperialism" or "control" by common carrier systems, or telephone, or broadcast services. 


\section{TELEVISION}

\section{General}

2148 "Television Within Decade, Prediction of New Yorker; Hawaii Will See Mainland,"' $S$ - $B$, December 30, 1932, 1: 2 .

Article stresses television would be a private business enterprise, and each "television machine" would cost at least $\$ 500$.

2149 "Television Here on Film Possible, Says NBC Visitor," $A D V$, June 19, 1948, 9: 5 .

Discussion of use of $16 \mathrm{~mm}$ film, airmailed from mainland USA for use in Hawaii.

2150 “Mainland TV for Hawaii Predicted,” $A D V$, March 21, 1950, 5: 1.

Reviews comments of Lee deForest, inventor of vacuum tube, about television for Hawaii.

2151 “FCC Agrees to Territorial Use of Video," $A D V$, March 23, 1951, 3: 2.

FCC lifted its 1948 freeze on TV channel allocations; gave go-ahead for Hawaii TV station applications.

2152 “TV Firm Seeks TV Freeze Exemption," $A D V$, January 20, 1951, 2: 1.

Aloha Broadcasting Corporation seeks exemption so Hawaii can have TV station.

2153 “Joe Rock Begins TV Production Here," $S$ - $B$, June 2, 1951, 22: 3.

Announcement that Hollywood producer forming Hawaii TV corporation.

2154 "'Little Chance for TV Here in Near Future O'Donnell Says," $A D V$, June 17, 1951, 10: 6 .

Manager of Territorial Agencies, Ltd., says FCC freeze on frequency allocations and other problems will delay TV in Hawaii.

2155 "Hawaii to be Subject of TV Films Produced in Islands," $S$ - $B$, October 26, 1951, 1: 4.

Reports William F. Broidy Productions will produce 52 half-hour color films in islands.

2156 “Television Still Far Off, Isle Radio Chain Head Says," $S$ - $B$, November 30, 1951, 19: 1 .

President of Hawaiian Broadcasting Systems reviews many problems to be worked out before islands get TV.

2157 "TH Allocated 20 Channels for Television," $A D V$, April 13, 1952, 1: 3.

FCC's three-year freeze on new channels ended; six identical channels awarded to Honolulu and to Hilo, four identical channels awarded each to Lihue, Kauai and to Wailuku, Maui. Four of these twenty channels would be for educational purposes only.

2158 Brosnan, John. "Late 1953 Believed Earliest Date for Hawaii Television," $S-B$, April 14, 1952, 1: 4.

Reviews problems in starting up TV operations in Hawaii.

2159

"Hawaii's Television Pattern Emerges But Still Indistinct," $S$-B, April 25, 1952, 1: 7 .

A survey of Hawaiian radio station's plans for TV operations. 
2160 “FCC Called on to Decide Hawaii TV Channel Dispute," $S$ - $B$, June 5, 1952, C-4: 7 .

Mutual Telephone Company of Hawaii wants TV channels 5 and 6 for interisland radio telephone service; National Association of Radio and Television Broadcasters (NARTB) wants the channels for TV use.

2161 “'Economic Gain for Honolulu Seen from TV,' $A D V$, November 16, 1952, 18: 6 .

Hoffman Radio Corporation officer stresses benefits of TV.

2162 “First TV Test Patterns Are Screened Here," $A D V$, November 18, 1952, 6: 8. Announces KONA-TV test successful.

2163 “'Television News, Features and Announcements,"' $S$ - $B$, December 8, 1952, 1:

3; B-1 to B-22 (entire section).

Special section with many articles on television activities.

2164 “6,500 Television Sets in Isles, Video Man Says,” $S$ - $B$, December 16, 1952, 5 : 7.

Estimate given by KGMB official.

2165 “'Bright Future for TV in Hawaii Predicted," $A D V$, December 17, 1952, 1: 7.

Official of Advertiser Publishing Co., Ltd., predicts there will soon be only two or three radio stations due to TV's competition.

2166 "Two Groups Held Responsible for Smooth Advent of TV Here," $S$ - $B$, March 13, 1953, C-2: 1 .

Reviews efforts by Better Business Bureau (BBB) and Television and Radio Association of Hawaii (TRIA) in this matter.

2167 “TV Film on Hawaii Ready in NY,” $S$ - $B$, April 9, 1953, 6: 7.

Film photographed by Tom Matsumoto about "Hawaii as a modern community" ready to be shown in New York state.

2168 "TV Man Says: Color Television Won't Arrive Here for Four to Five Years," $S-B$, December 11, 1953, 26: 4 .

Packard-Bell Company official says delay in color television for Hawaii due to TV station costs, small size of the color TV screen, cost of set to owner, problems in TV-receivers and expense of repairing them.

2169 Coll, Ray. “TV Sets in Use Here May Total 40,000,” $A D V$, May 16, 1954, 1:

4.

Article reviews statistics about television in Hawaii: there are 20 brands of TV receivers sold in Hawaii; TV has been "on the air" for about 18 months; distributors estimate number of sets from 32,000 to 55,000 .

2170 “'Survey Indicates Radio, TV Habits of Oahu Families,' $S$ - $B$, March 14, 1955, 16: 1 .

Survey reveals that television reaches about $58 \%$ of the 98,000 families on Oahu; radio listening remains popular.

2171 “Color Television Still 2 Years Off for Islands," $S$ - $B$, December 1, 1955, 34: 5. Hawaiian Broadcasting System official makes prediction on color TV and "pay TV" issue. 
2172 “RCA Chairman Predicts Direct TV Broadcasts," $S-B$, February 29, 1956, 12: 1 .

David Sarnoff predicted that within 5 years there would be direct mainland to Hawaii television broadcasts.

2173 “'Trans-Pacific 'Live' TV Predicted by N.B.C. Star," $S-B$, August 15, 1956, 12: 4 .

George Wolfe reviews new TV developments.

2174 “"Meteor Enters TV Picture,” $A D V$, July 12, 1957, B-1: 4.

Reports research by Ralph Thomas into very high frequency radio signals which potentially could allow direct mainland-Hawaii television transmission.

2175 "Pay-to-See Television is Favored," $A D V$, July 15, 1957, 2: 6.

Reviews positive opinions of Zenith Radio Corporation official about pay television and radio broadcasting's continued development.

2176 "Station Spokesman Says Color TV is Here to Stay Despite Slow Start," $S-B$, January 17, 1958, 18: 5.

KHVH-TV official apologized for small number of color TV programs available to the station. Estimates of color TV sets in local homes range from 80 to 400 .

2177 "How to Buy Broadcast Advertising in Hawaii," Broadcasting, 58, no. 3 (January 18, 1960): 73-74, 77-78.

Describes television and radio coverage, market characteristics, and programming patterns.

2178 “The Real Magic of the Islands," Broadcasting, 58, no. 3 (January 18, 1960): $67-70,72-73$.

A general feature on Hawaii and its social and economic climate; includes list of television and radio stations in operation.

2179 “'Group Seeks Pay TV Here,” $A D V$, March 29, 1961, A-6: 1.

Announcement that local group of businessmen plan pay-TV organization; proposal is for a 2-channel system providing bi-lingual programming.

2180 “'Radio-TV Set Counts," Broadcasting, 62, no. 4 (January 22, 1962): 90.

Tabular data on radio and television sets in use in Hawaii.

2181 Hunter, Gene. "Isles May Get Satellite TV in 3 to 6 Years," $A D V$, March 4, $1964,1: 6 ; 2: 6$.

Reviews Hawaiian Telephone Company official's discussion of difficulties of starting live TV via satellite to Hawaii.

2182 "'Live TV in 4 Years," $S$ - $B$, September 10, 1964, 1: 5.

Reviews Hawaiian Telephone Company plans for showing sports events via satellite TV

2183 Frankel, Chuck. " 'Live' TV Looms as Big Asset for Isles," $S$ - $B$, December 19, 1964, B-1: 1 .

Reports plans by Hawaiian Telephone Company and Communications Satellite Corporation for bringing live TV to islands by 1966; detailed comments on cost of providing programming.

2184 “Only Limited Satellite TV Likely Here,”' $S$ - $B$, January 29, 1965, 1: 1; 4: 3. Communications Satellite Corporation official explains that high costs will limit satellite "live" TV programming. 
2185 “TV Satellite Relay Site to be on Oahu,” $S$-B, April 22, 1965, 1: 1.

Announcement by Hawaiian Telephone Company and Communications Satellite Corporation.

2186 Anderson, Burt. “Satellite TV Reception Here Seen for 1966," SBA, May 23, 1965, A-7: 7.

Hawaiian Telephone Company announcement.

2187 “Joining the Network," $A D V$, December 28, 1965, B-2: 1.

Editorial praising benefits of live TV from mainland.

2188 Schneider, Emil A. “Live TV Assured for 1967,"' $A D V$, April 22, 1966, A-1: 8.

New prediction by Hawaiian Telephone Company.

2189 “Live TV Via Satellite to Cost $\$ 150$ a Minute," $A D V$, October 28, 1966, 1: 5;

6: 5 .

Hawaiian Telephone Company expects to pay Communications Satellite Corporation (COMSAT) $\$ 150 /$ minute for first 10 minutes of live programs from mainland; rate to drop to $\$ 42 /$ minute after that.

2190 Baker, Byron. "First Live TV Broadcasts Viewed in Isles Today," $S$ - $B$, November 18, 1966, A-1: 5 .

Reviews TV test patterns from mainland via satellite; notes first live TV programming expected by Honolulu stations.

2191 “Role of Television in Society,” $S$ - $B$, January 13, 1967, B-2: 1. Interviews with young adults on the impact of television on their lives.

2192 Harada, Wayne. "It's Live TV to Japan: Lani Bird Relays Aloha," $A D V$, February 20, 1967, A-1: 1 .

Reports special program about Hawaii beamed to Japan via satellite.

2193 Mayer, Phil. “Live TV From Japan Major Feat,’' S-B, March 9, 1967, A-2: 1. Reviews first Japanese program beamed to Hawaii via satellite.

2194 “Color TV Sets Now in 15\% of Isle Homes," $S$ - $B$, July 10, 1967, B-4: 4.

Reports American Research Bureau survey results: 22,600 Isle homes have color TV sets; $22 \%$ have more than one TV set.

2195 “Hawaii Trails Most States in TV Percentages," $S$ - $B$, August 7, 1967, A-12: 4. Reports conclusions of American Research Bureau's survey: 89\% of Hawaii homes have TV sets.

2196 Lynch, Russ. "New Satellite Would Cut Cost of Live Color TV Here," $S$ - $B$, January 30, 1969, B-2: 1.

Reviews benefits available from Intelsat III satellite (transmission of 4 TV channels) over presently used Lani Bird type (Intelsat II), which allows only one TV channel to be beamed from mainland to Hawaii.

2197 “Color TV Sets on the Increase,” $S-B$, February 21, 1969, D-5: 1.

American Research Bureau reports $31 \%$ of Honolulu's TV-receiving households have color sets.

2198 “Isle TV is 'Losingest' in U.S.," $S$ - $B$, July 31, 1970, B-6: 1.

FCC report shows Honolulu's four TV stations lost $\$ 1.4$ million in 1969 , more than stations in any other U.S. city. 
2199 “TV Earth Station Sought," $A D V$, December 23, 1970, B-4: 3.

Hawaiian Telephone Co. filed application with the FCC to build a new satellite station for live Mainland broadcasts.

2200 Jones, Bob. "TV at the Legislature," Hawaii Journalism Review, 1, no. 1 (February 1971), not paged.

Criticizes coverage of the state legislature by local television stations as inadequate.

2201 Youngblood, Ron. "Ripping Off the News," Hawaii Journalism Review, 1, no. 6 (October 1971), not paged.

Chastises local broadcasting stations for relying on news items lifted directly from local newspapers.

2202 Bruckner, Doug. "Hawaii Television: Get Some Guts!" Hawaii Journalism Review, 2, no. 3 (March 1972), not paged.

Discusses the reluctance, sometimes refusal, of local television stations to broadcast network public affairs programs.

2203 “New 'Bird' Will Cut Some Costs,” S-B, December 12, 1975, F-8: 1.

New communications satellite launched in Florida will do little to bring more live television coverage from the mainland since costs are prohibitive.

\section{Cable}

2204 “Aina Hainans Discuss Community TV Aerial," $A D V$, February 6, 1953, 7:

2.

Problems and advantages of a community TV system discussed at meeting.

2205 "Kaiser Plans Closed TV at Hawaii Kai: One Antenna to Serve New Community," $S$ - $B$, November 25, 1960, 1: 8.

Announcement of new cable TV corporation to provide all Honolulu TV channels' service to Hawaii Kai area.

2206 “TV Service Sought for Aina Haina," $A D V$, August 10, 1962, 1: 3.

Reviews Kaiser Industries Corporation application to Honolulu City Council for cable service.

2207 "Firm to Offer 'Perfect' Reception to TV Viewers in Fringe Areas," $S-B$, April 5, 1963, 21: 1 .

Reviews goals of Pacific Network, Inc., in providing various TV services.

2208 "Community Antenna TV System Serves Kalihi Valley Area," $S$ - B, October 12, 1964, 17: 4 .

Announces cable TV service.

2209 “North Shore Group Seeks Cable TV," $S$-B, November 8, 1969, B-8: 8.

Reports on activity of residents of outlying areas in Hawaii to get cable TV services.

2210 “Cable TV Gets Boost,” $A D V$, December 4, 1969, E-7: 3.

Reports that Hawaiian Telephone Company will allow cable TV companies to use telephone poles for their cable wires.

2211 “Isle TV Studio is Expanding,"' SBA, January 3, 1971, Aloha Magazine, p. 1. Hawaiian Video Industries (HVI) is expanding to consolidate with Sunset Films of Portland, Oregon, and Trans Pacific Films in Honolulu. 
2212 "State to Issue Six Permits for Expansion of Cable TV," $A D V$, August 13, 1971, A-16: 3.

Six of fifteen requests for expanded cable service to new areas of Oahu and Hawaii were approved.

2213 “Denver CATV Firm Buys Hawaii Interest," $S$ - $B$, January 31, 1972, D-5: 4.

Cablecom-General Inc. has purchased Castle \& Cooke's CATV interests; mainland chain will acquire 85 per cent of the outstanding stock of Oceanic Cablevision Inc., owned by Oceanic Properties Inc. (a Castle \& Cooke subsidiary).

2214 Morrissey, Penny. "Cable Television: Will the System Prove Profitable Here?" $A D V$, February 14, 1973, E-8: 1.

Reviews early history of CATV in Hawaii, some of the companies competing for territory in Hawaii and their plans for expansion; map shows present and potential areas served by each company.

2215 “The Cable TV 'Revolution',” $A D V$, February 19, 1973, A-14: 1.

Editorial reviews some of the problems and potentials of CATV.

2216 Creamer, Beverly, and Carl Wright. "Speculation in Cable TV Permits Aired in House,"' $S$-B, March 28, 1973, A-16: 4.

Article reviews problems in cable TV companies' state permits potentially being "peddled" for profit.

2217 Senda, Warren. "Decision on Cable TV Rights 'Imminent'," $A D V$, July 4, 1973, C-9: 1.

Edwin Honda, State Department of Regulatory Agencies head, says decision on CATV applications will come within a month.

2218 Boswell, Douglas. "Contract to Cover 93,000 Homes; Cable TV in 2 Years," $A D V$, July 14, 1973, A-1: 1.

Hawaii State government announces CATV system will be built; article reviews permit by company providing the service.

2219 “Movie House Battles Cable TV,” PICN, 4, no. 1 (August 1973): 10.

Discusses competition for audiences on island of Hawaii.

2220 “Go-Ahead Given for Kona CATV," S-B, September 18, 1973, A-3: 3.

West Hawaiian Cable Vision Ltd. granted approval for CATV franchise on Big Island (Hawaii).

2221 “Cable TV Expands,” PICN, 4, no. 2 (December 1973): 10.

Brief article describes growth of cable television on the island of Hawaii.

2222 "Land Board OKs TV Relay Site," $A D V$, April 26, 1974, A-14: 1.

Article reviews Oceanic Cablevision report to State Land Use Commission concerning TV for North Oahu area.

2223 “Cable TV Firm Arranges Financing," $S$-B, May 13, 1974, C-7: 3.

Oceanic Cablevision Inc. arranged loan for building Oahu TV network.

2224 Bowman, Pierre. "Big Brother Cometh on Cable TV," SBA, May 19, 1974, C-1: 1 .

Oceanic Cablevision Inc. starting operations in several days; article reviews futuristic changes that could occur in life-styles due to new system. Map illustrates service areas. 
2225 Burris, Jerry. “Auditor: CATV Needs Regulation," $A D V$, September 3, 1975, A-4: 3 .

Article reviews Legislative Auditor's report on potential problems of unregulated CATV networks.

2226 . “It's Cable TV versus PUC," $A D V$, October 4, 1975, A-8: 2.

Hawaiian Cable TV companies present arguments against State PUC regulation.

2227 Feliciano, Grace. "Cable TV in Service at St. Louis," $S-B$, October 9, 1975, C-8: 1 .

Reviews three-channel CATV system at St. Louis High School.

2228 "Unique English Classes Put Students in the Picture," $S B A$, November 9, 1975, A-12: 1.

Article about news program prepared by college students and aired on cable TV.

2229 “Cable News Report Debuts in Hawaii," PICN, 5, no. 4 (December 1975): 6.

UPI news report for cable television via satellite made debut in Hawaii July 21, 1975.

2230 “Cable TV for Maui Within One Year," PICN, 5, no. 4 (December 1975): 8.

CAMP, INC., has been awarded franchise for Maui CATV service.

\section{Foreign-Language Broadcasting}

2231 “KGMB-TV Casts First Japanese Live Program," $S$ - $B$, December 22, 1952, 4: 1 .

Reports 90 -minute feature program in Japanese language.

2232 “Group Seeks Pay TV Here,” $A D V$, March 29, 1961, A-6: 1.

Announcement that local group of businessmen plan pay-TV organization; proposal is for a 2-channel system providing bi-lingual programming.

2233 "Bureau Criticizes Language Survey," Broadcasting, 72, no. 15 (April 10, 1967): 80.

Reports recommendation by FCC Broadcast Bureau that proposed sale of KTRG-TV, Honolulu, by Hawaiian Paradise Park Corp. to Friendly Broadcasting Co. be disapproved; Bureau critical of survey to demonstrate need for Japanese- and Filipino-language programming.

\section{$K A I I-T V$ \\ See KHON-TV \\ $K G M B-T V$}

KGMB-TV began operations in Honolulu December 1, 1952. KGMB-TV also operates KPUA-TV in Hilo, Hawaii (May 15, 1955-) and KMAU-TV in Wailuku, Maui (April 24, 1955-).

2234 “Oahu's Sixth TV Application Made," $S$-B, July 15, 1952, 7: 6.

Radio Station KGMB applied for Channel 9.

2235 “KGMB Receives Permit to Build Station for TV," S-B, August 6, 1952, 1: 8.

Hawaii Broadcasting System, which operates radio stations KGMB, Honolulu, and KHBC, Hilo, granted building permit. 
2236 "KGMB Working to Start TV Before End of this Year," $S-B$, October 22, 1952, 1: 3 .

Announces 500-watt TV station (Channel 9) will operate on interim basis soon.

2237 "Green Light Given KGMB to Start TV by December," $S-B$, October 30, 1952, 1: 8 .

FCC approves KGMB's temporary TV station.

2238 Brosnan, John. "Honolulu Stations in Race to be First on Air with TV," $S$-B, November 11, 1952, 1: 7 .

KGMB announced December 1, 1952, as target date to start operations, while KONA's starting date uncertain.

2239 "First Regular Isle Telecasts Begin Tonight on KGMB-TV," $S$ - $B$, December $1,1952,1: 6$.

Announcement.

2240 "Impressed Islanders Watch First Television Broadcast," $S$ - $B$, December 2, 1952, 1: 6; $A D V$, December 2, 1952, $1: 7$.

Announcement of first day's programming over KGMB-TV; several other articles on TV programming, benefits, etc.

2241 “KGMB Prepares TV Reception for Other Isles," S-B, May 19, 1953, B-2: 4.

Channel 9 will open new transmitter in August that will allow all of Island of Oahu and parts of other Hawaiian islands to have TV reception.

2242 "Hilo to Get Television Within Year," $S$-B, November 23, 1953, 1: 6.

KGMB official predicts estimated 35,000 to 40,000 prospective Island of Hawaii TV owners will be able to get TV reception due to stronger KGMB-TV equipment.

2243 "Hawaiian Broadcasting System Plans Television Station on Valley Island," $A D V$, November 27, 1954, A-7: 2.

Reports application for Channel 3 on Maui was filed with FCC.

2244 "Application Filed for Television Station in Hilo," $S$ - B, December 15, 1954, 14: 3.

Hawaii Broadcasting System applied to FCC for Channel 9 in Hilo.

2245 “TV Satellite Approved For Maui, Big Island,” S-B, January 20, 1955, $27: 7$.

FCC approved Hawaiian Broadcasting System's application to build facilities for rebroadcasting KGMB-TV programs from Honolulu to two other Hawaiian islands.

2246 "Honolulu Group Buys Star-Bulletin Control," Editor \& Publisher, 94, no. 47 (November 25, 1961): 15.

Reports sale of Honolulu Star-Bulletin and its broadcast properties, KGMB-AM-TV, Honolulu; KHBC-AM-TV, Hilo; KMAU-TV, Wailuku.

2247 "Sale Closing in Honolulu Set April 30," Editor \& Publisher, 95, no. 13 (March 31, 1962): 13.

Formal signing of contract for sale of Honolulu Star-Bulletin and its broadcast stations set for April 30, following FCC approval of transfer of ticenses for KGMB-AM-TV, Honolulu; KHBC-AM-TV, Hilo; KMAU-TV, Wailuku. 
2248 "Third Honolulu Sale Gets FCC Approval," Broadcasting, 68, no. 19 (May 10, 1965): 54 .

Reports FCC approval of sale of stations KGMB-AM-TV, Honolulu; KHBC-AM-TV, Hilo; KMAUTV, Wailuku, by Honolulu Star-Bulletin to A. L. Glasman family; recaps earlier sale of KONA-TV and of Kaiser stations KHVH-AM-FM-TV, Honolulu, and KHVO-TV, Hilo, to Lawrence S. Berger.

2249 "Heftels Become Sole Owners of KGMB, KPUA," S-B, February 26, 1972, A-6: 3.

Cecil L. Heftel and his wife, Joyce, bought out other stockholders of Hilo radio station KPUA and Honolulu's KGMB radio and television outlets.

\section{$K H A W-T V$}

See KHON-TV

\section{KHET-TV}

KHET, Honolulu's educational television channel owned by Hawaii Public Broadcasting Authority, began operations April 15, 1966; also operates KMEB-TV, Wailuku, Maui, which began operations September 22, 1966. For citations see section titled EDUCATIONAL MEDIA - Television.

\section{KHON-TV}

KHON-TV began operations in Honolulu December 15, 1952. KHON-TV also operates KAII-TV in Wailuku, Maui (November 19, 1958-) and KHAW-TV in Hilo, Hawaii (November 27, 1961-). Previous call letters of KHON-TV were: KPOA, KONA-TV; of KAII-TV: KALA-TV; of KHAW-TV: KALU-TV.

2250 "KPOA Asks TV License; Could Start by May of '51," $S-B$, November 16, 1950, 8: 4 .

Article says FCC holding back on TV licenses for Hawaii. KPOA planning to use mostly mainland programs, airmailed to Hawaii, but also produce some local programs.

2251 "TV Freeze May be Lifted; 3 Local Firms May Apply," $S$ - $B$, February 29, 1952, 3: 1 .

Pacific Frontier Broadcasting Company (KULA), Island Broadcasting Company (KPOA), and Radio Honolulu Ltd. (no call letters), say they will file TV channel application with FCC.

2252 “Two Isle TV Applications Are Filed," S-B, June 5, 1952, 1: 3.

Advertiser Publishing Co. Ltd. (Channel 4), Royaltel of Honolulu (Channel 2), applied to FCC for TV permits; KULA radio station in same process.

2253 "Station KPOA Files for Video Channel Sought by 'tiser," $S$ - $B$, July 7, 1952, 1: 5 .

Island Broadcasting Co. (KPOA) also applies for Channel 4.

2254 “Radio Honolulu Ltd., Gets City's Second TV License," $S-B$, October 24, 1952, 1:1.

Announces building plans. 
2255 Brosnan, John. "Honolulu Stations in Race to be First on Air With TV,' $S$ - $B$, November 11, 1952, 1:7.

KGMB announced December 1, 1952, as target date to start operations, while KONA's starting date uncertain.

2256 “Radio Honolulu Gets Special TV Permit," $S$-B, November 14, 1952, 1: 3.

FCC grants temporary permit for TV operation.

2257 “First TV Test Patterns Are Screened Here,"' $A D V$, November 18, 1952, 6: 8.

Announces KONA-TV test successful.

2258 "KONA-TV Plans to Go on Air Very Soon,"' $A D V$, November 11, 1952, 1: 3.

Radio Honolulu Ltd., television announcement.

2259 “KONA-TV Plans Daily Programs by End of Week," $S$ - $B$, December 8, 1952, 1: 1 .

Short announcement.

2260 “KPOI, Advertiser Buy KONA-TV Plant," $A D V$, March 10, 1953, $1: 1$.

Announcement that KONA-TV will be purchased by local buyers.

2261 “KONA-TV Sale OK, to Go on Air June 17," $A D V$, June 4, 1953, 1: 2.

Radio Honolulu, Ltd., owned by the Advertiser Publishing Company and Island Broadcasting Company, gain control of KONA-TV.

2262 “KONA-TV Inaugural Program June 24," $A D V$, June 14, 1953, 1: 3.

Announcement that Channel 11 starting operations.

2263 “FCC Approves KONA Switch to Channel 2," $A D V$, June 23, 1955, A-1: 7.

KONA-TV has FCC approval for switching channels and doubling its station's power.

2264 “'KONA-TV Shows Move to Powerful Channel 2,' $S$ - $B$, October 22, 1955, 6: 3.

Article reviews technical changes in KONA-TV station.

2265 "KONA's Programs Rate Tops in 'Pulse' Survey," $A D V$, April 13, 1956, A-10: 6 .

Pulse survey revealed that KONA-TV had eight programs in the "top 15" programs on Oahu since their power boost; last year KONA-TV had one program in the "top 15."

2266 "KONA-TV First on the Air in Hawaii," $A D V$ (Centennial Edition), July 1-7, 1956, I-24: 3.

Article reviews first TV broadcast in Hawaii, held in a Honolulu radio station on November 17, 1952, and official debut for local TV watchers held December 11, 1952.

2267 “'KONA-TV Sale Set for About \$3 Million,” $S-B$, October 7, 1964, 1: 1.

Reports planned sale of Honolulu television station KONA-TV and its repeater stations on Maui, Kauai, and Hawaii.

2268 “Crosley Invades Washington,” Broadcasting, 68, no. 18 (May 3, 1965): 64.

Roundup story on sales transactions; includes notice of FCC approval of sale of KONA-TV in Honolulu, KALA-TV in Wailuku, and KALU-TV in Hilo, by Radio Honolulu, Inc., to Communications Honolulu, Inc., owned by DeSales and Paulette B. Harrison. 
2269 “'KHON Owner Involved in 3-way Merger,"' $S$ - $B$, November 17, 1967, A-13: 3.

FCC approved merger of three companies involved in TV station; new name to be Pacific and Southern Broadcasting Company, Inc.; stations involved are KHON-TV in Honolulu and its satellite stations, KAII-TV in Wailuku, KHAW-TV in Hilo, and mainland radio stations.

2270 “KHON-TV Sale is Official,” $S-B$, January 19, 1973, B-5: 2.

The FCC approved sale of KHON-TV by Pacific and Southern Broadcasting to the McCoy Broadcasting Co. The McCoy company also owns KAII-TV, Maui; KHAW, Hilo; and K-78AR, Kauai.

\section{KHVH-TV \\ See KITV \\ KHVO-TV}

See KITV

$K I K U-T V$

KIKU-TV began operations in Honolulu July 4, 1962. Previous call letters of KIKUTV were KTRG-TV.

2271 “Authorization is Given for Fourth TV Station,"' $S$ - $B$, April 27, 1962, 1: 1.

FCC approves station owned by Hawaiian Paradise Park Corporation; call letters KTRG-TV. Station planning 7 hours of programming daily as a start.

2272 Darr, Bert. "Honolulu's Fourth TV Station, KTRG-TV, Goes on Air Tonight,' $S$ - $B$, July 4, 1962, 42: 5.

Announcement of new TV station, Channel 13; article briefly outlines history of other Honolulu TV stations.

2273 “'Bureau Criticizes Language Survey," Broadcasting, 72, no. 15 (April 10, 1967): 80.

Reports recommendation by FCC Broadcast Bureau that proposed sale of KTRG-TV, Honolulu, by Hawaiian Paradise Park Corp. to Friendly Broadcasting Co. be disapproved; Bureau critical of survey to demonstrate need for Japanese- and Filipino-language programming.

2274 “'Nod Goes to Eaton for Honolulu Sale," Broadcasting, 73, no. 5 (July 31, 1967): 37.

Reports recommendation of an FCC hearing examiner that approval be granted to proposed sale of KTRG-TV, Honolulu, by Hawaiian Paradise Park Corp. to Friendly Broadcasting Co.

2275 “'KTRG-TV Sold to Ohio Corporation,” $A D V$, September 23, 1967, A-2: 7.

Announces Friendly Broadcasting Company purchased KTRG-TV station; previous owners, Watumull Broadcasting Company, will continue to manage it.

2276 “'KIKU to Stress Japanese Shows," $A D V$, October 5, 1967, B-5: 4.

Announces that KTRG-TV (Channel 13) was purchased by Richard Eaton, who will change call letters to KIKU-TV; plans English and Japanese language programming.

2277 “'He's Got Us All Wired for Sound,' $S$ - $B$, August 27, 1974, D-8: 1.

Feature on Allen Roycraft's association with 13 AM, two FM radio stations, and KIKU-TV as chief engineer. 


\section{KITV}

KITV began operations in Honolulu April 16, 1964. KITV also operates KHVO-TV in Hilo, Hawaii (May 15, 1960-). Some of KITV's programming is rebroadcast to KMVI-TV (December 4,1955-), a separately owned station in Wailuku, Maui. Previous call letters of KITV were: KULA; KHVH-TV.

2278 "Further Study of Television Here," S-B, December 1,1950, 11: 4.

Revicws KULA radio station's plans for TV station.

2279 "TV Freeze May be Lifted; 3 Local Firms May Apply," S-B, February 29, 1952, 3: 1 .

Pacific Frontier Broadcasting Company (KULA), Island Broadcasting Company (KPOA), and Radio Honolulu Ltd. (no call letters), say they will file TV channel applications to FCC.

2280 "KULA Manager May Seek Ban on T.H. Land Levee to Mutual," $S$ - $B$, June 6, 1952, 1: 3; $A D V$, June 7, 1952, 3: 3.

Reports KULA and Mutual Telephone Company conflict on TV land lease.

2281 "KULA Attorney, Land Official Will Meet to Study Land Case," S-B, June 9, 1952, 1: 5 .

Concerns KULA land case.

2282 "4th Application for TV Station Scheduled Today," S-B, July 1, 1952, 7: 1.

Pacific Frontier Broadcasting Co. (KULA) has applied for Channel 2; Radio Honolulu, Ltd., planning to apply for Channel 11 .

2283 "American Broadcasting Files for TV Channel 4 With FCC," $S$-B, April 8, 1953, 8: 1 ,

Company that purchased station KULA will apply for Channel 4 also.

2284 "2 Honolulu Firms Ask Delay in Hearings for TV Channel 2," S-B, May 27, 1953, 1: 1 .

Pacific Frontier Broadcasting and Royaltel of Honolulu ask for delay since they are considering applying for joint use of Channel 2 .

2285 "KULA-TV Expected to be Broadcasting by First of 1954," S-B, September $10,1953,6: 6$.

Short announcement for KULA-TV; RoyalTel's application for Channel 2 has been postponed by FCC.

2286 "RoyalTel Quits Television Bid on Channel 2," $A D V$, October 8, 1953, 1: 3.

RoyalTel withdraws application for Channel 2.

2287 "Third TV Station Here to Go on Air Officially April 16," S-B, March 16, 1954, 22: 1 .

Reviews schedule of start of broadcasting by Pacific Frontier Broadcasting Company's KULA-TV.

2288 "KULA Television Goes on Air Over Channel 4," ADV, April 17, 1954, A-6: 1 .

Reviews opening of third television station in Hawaii. 
2289 Johnson, Robert. "Kaiser to Start New Hotel, Color TV; Work to Begin Next Wednesday," $S-B$, August 29, 1956, 1: 4.

Announces Henry J. Kaiser plans for hotel and color TV and radio broadcasting station in Honolulu.

2290 "Kaiser Gets Ball Rolling on His Color TV Station," $A D V$, September 20, 1956, C-1: 3.

Reviews technical information on TV station.

2291 "F.C.C. Okays Kaiser Television Station: Islands Will Get Color TV Soon," $S-B$, April 8, 1957, 1: 6.

Announcement that KHVH-TV (Channel 13) will go on air soon; however, KHVH radio station-the tenth in Honolulu-had to stop operations pending investigation into charges that ten radio stations are "too much." Television station is scheduled to broadcast 12 hours per day with two hours being in color.

2292 "Kaiser TV Station Forecasts First Island Shows in Color," S-B, May 6, 1957, 5: 1 .

Reports that an estimated 2,500 persons saw the first color TV show in Honolulu. Programming was on film.

2293 "Station Spokesman Says Color TV is Here to Stay Despite Slow Start," $S-B$, January 17, 1958, 18: 5 .

KHVH-TV official apologized for small number of color TV programs shown on station. Also, survey of color TV sets in Hawaii.

2294 "Kaiser Buys KULA-TV for $\$ 685,000$ : Deal Subject to Approval by F.C.C.," $S$ - $B$, May 8, 1958, 1: 8 .

Reports that until sale is final KHVH-TV will broadcast on Channel 13, then will transfer to Channel 4.

2295 "Kaiser's Station KHVH Will Import \$250,000 'TV Station on Wheels'," $S-B$, January 24, 1960, 9: 1 .

Reports first mobile video-tape unit in Hawaii.

2296 Turner, Charles. "Kaiser Sells KHVH in \$4 Million Deal," $A D V$, October 8, 1964, A-1: 1; A-8: 6 .

Pacific Broadcasting Company purchased KHVH; third Hawaiian television station to be sold in a 5month period, leaving only one station with original owners.

2297 Bruckner, Doug. "It's All on the Cutting Room Floor," Hawaii Journalism Review, 2, no. 1 (January 1972), not paged.

Reviews problems of designing a daily TV news show for Hawaii, based on KHVH-TV experience.

2298 "KHVH-TV Sold to New Orleans Company," $S-B$, November 16, 1972, F-9: 1 .

Starr Broadcasting Group will purchase KHVH-TV in summer 1973. Satellite KHVH station in Hilo, KHVO-TV, is included. 


\section{KMAU-TV}

See KGMB-TV

$K M E B-T V$

See KHET-TV

KMVI-TV

KMVI-TV began operations in Wailuku, Maui, December 4, 1955. A large amount of its programming comes from separately owned KITV in Honolulu.

2299 “Maui News to Seek Permit For Haleakala TV Station,” $A D V$, April 9, 1955, A-1: 3 .

Maui Publishing Company applies to FCC for Channel 12 (KMVI-TV); would be affiliated with KONA-TV in Honolulu.

2300 “'New Maui TV Station Approved," $A D V$, May 27, 1955, B-5: 6.

FCC approval of Maui Publishing Company application for Channel 12.

$$
\text { KONA-TV }
$$

See KHON-TV

KPOA

See KHON-TV

KPUA-TV

See KGMB-TV

KTRG-TV

See KIKU-TV

KULA

See KITV 


\section{Johnston Island}

NEWSPAPERS, PERIODICALS

2301 The Breeze. 1948?- . Daily newssheet in English.

\section{RADIO BROADCASTING}

2302 "Special Broadcast from Johnston Is.," PIM, 23, no. 2 (September 1952): 114.

Reports plans for test transmissions from Armed Forces Radio Service station WVTV. 


\section{Midway Island}

\section{TELEVISION}

2303 "They've Got Television on Midway Now," PIM, 29, no. 9 (April 1959): 121. Reports installation of U.S. Armed Forces Television facility. 


\section{Nauru}

NEWSPAPERS, PERIODICALS

2304 THE BULLETIN. 1971 — . Biweekly in English published by Republic of Nauru. Succeeded News Bulletin (1965-1971), published biweekly by government; Nauru News (1954-1965), a weekly published by administration.

2305 CENTRAL PACIFIC POST. Brisbane. 1969-?

2306 GOVERNMENT GAZETTE. See Nauru (Republic) Government Gazette.

2307 NAURU GOVERNMENT GAZETTE. See Nauru (Republic) Government Gazette.

2308 NEWS BULLETIN. See The Bulletin.

2309 NAURU NEWS. See The Bulletin.

2310 NAURU (REPUBLIC) GOVERNMENT GAZETTE. Nauru. 1968-. Weekly. Supersedes Nauru Government Gazette (1949-January 1968); generally weekly. Supersedes Government Gazette (1921-1949?), irregular. Supplement issued occasionally. Published by Government Printer.

2311 NAURU TIMES. Nauru. 1947-? Weekly.

2312 PINNACLE PRESS. 1967-? Weekly in English.

FREEDOM OF THE PRESS/BROADCASTING

2313 “BBC Not Welcome in Nauru," PIM, 42, no. 2 (February 1971): 40.

Reports refusal of Nauru government to issue entry permit to BBC team to film observance of anniversary of Nauruan independence and scenes of everyday life.

\section{THE PRESS}

2314 “The Education of Nauruans," PIM, 8, no. 3 (October 1937): 49.

Notes publication of Nauruan Scouter by Nauru Education Director in conjunction with Boy Scout movement; contains some general news. 
2315 "Islands Newspapers: How War and Socialism Killed Territories Journals," PIM, 17, no. 9 (April 1947): 59.

Notes publication of Nauru Times, weekly newssheet.

2316 “Nauru's Pools Not Yet Off the Ground," PIM, 40, no. 3 (March 1969): 31. Postscript to article on sports reports appearance of two issues of Central Pacific Post, a newspaper for Nauru printed in Brisbane.

\section{RADIO BROADCASTING}

2317 “Broadcasting Station for Nauru," PIM, 26, no. 2 (September 1955): 157.

Cites reports of plans for small station on Nauru.

2318 “In a Nutshell," PIM, 36, no. 5 (May 1965): 15.

Reports capital cost of $£ 25,000$ for Nauru radio station approved by Australian Minister of Territories.

2319 “' 'Good Morning, This is Radio Nauru'," PIM, 39, no. 8 (August 1968): 32. Reports opening of Radio Nauru.

2320 “Nauru Radio Station Hours Listed,” PICN, 4, no. 4 (September 1974): 13. 


\section{New Caledonia}

\section{INDEXES, GUIDES, REFERENCE WORKS}

2321 O'Reilly, Patrick. Calédoniens Répertoire Bio-bibliographique de la NouvelleCalédonie. Publications de la Société des Océanistes no. 3. Paris: Musée de l'Homme, $1953.304 \mathrm{pp}$.

A biographical dictionary; includes journalists.

NEWSPAPERS, PERIODICALS

2322 ANDO MADÔ. Noumea. 1975—. Monthly. Published by Group 1878 in French and Houailou languages.

2323 AVANT GARDE. Noumea. -1975-. Monthly? Published by L'Union Progressiste Multiraciale.

2324 LE BULLETIN DU COMMERCE DE LA NOUVELLE CALÉDONIE ET DES NOUVELLES-HÉBRIDES. See Les Nouvelles Calédoniennes.

2325 BULLETIN OFFICIEL DE LA NOUVELLE-CALÉDONIE. 1853-1907. Monthly.

2326 LE CAILLOU: UNE CALÉDONIE POUR TOUS LES CALÉDONIENS. Noumea. 1973? - Bimonthly in French.

Economic and news magazine.

2327 LES CALÉDONIENS. Noumea. April? 1975-. Weekly in French. Published by M. J. Caillard.

2328 CICIQADRY. Noumea. 1972 - Monthly in French and Lifou languages.

2329 CORAIL. Noumea. 1961?-1966. Published twice a month in French.

2330 LE COURRIER ILLUSTRÉ DE LA NOUVELLE CALÉDONIE. Noumea. October $1878-1879$. 
2331 FETUUAHO: ÉTOILE DU MATIN. Noumea. 197?—. Monthly in French and Wallesian.

2332 FRANCE AUSTRALE. Noumea. 1889—. Daily in French.

2333 LA FRANCE AUSTRALE DiMANCHE. Noumea. 1969-June 30, 1974. Weekly in French.

2334 HEBDOMADAIRE. Noumea. 197? - Weekly.

2335 INFORMATIONS. Noumea. July 1, 1965-March 1967. Monthly in French. Published by Bureau de Presse.

2336 ILLUSTRÉ DE LA NOUVELLE CALÉDONIE. See Le Courrier Illustré de la Nouvelle Caledonie.

2337 LE JOURNAL CALEDONIEN. See Nouveau Journal Caledonien.

2338 JOURNAL OFFICIEL DE LA NOUVELLE-CALÉDONIE ET DÉPENDANCES. Noumea. October 2, 1959_- Originally titled Le Moniteur Impérial de la Nouvelle-Caledonie et Dépendances (for first 118 issues), then Le Moniteur de la Nouvelle Calédonie (-1886). Official gazette published semimonthly in French until February 1939, then weekly.

In 1862 general news items were introduced in gazette. Available on microfilm, Pacific Manuscripts Bureau.

2339 KANAK. Noumea. 1969-1973? Published twice weekly in French.

2340 MONITEUR IMPERIAL. See Journal Officiel de la Nouvelle-Calédonie et Dépendances.

2341 LE MONITEUR DE LA NOUVELLE-CALÉDONIE ET DÉPENDANCES. See Journal Officiel de la Nouvelle-Calédonie et Dépendances.

2342 NOUMEA BEACH PRESS. Noumea. February 1972-? Monthly in French and English.

2343 NOUMEA-SOIR. See Les Nouvelles Calédoniennes.

2344 NOUVEAU JOURNAL CALÉDONIEN. Noumea. February 27/March 5 , 1974_—? Weekly in French. Succeeded Le Journal Caledonien (1964-74).

2345 LES NOUVELLES CALÉDONIENNES. Noumea. 1974? - Published daily in French. Succeeded Noumea-Soir (1972?-74); Le Bulletin du Commerce de la Nouvelle Calédonie et des Nouvelles Hébrides (1859-1972?).

2346 REVEIL CANAQUE. Noumea. April? 1971-1974? Monthly, published by Union Multiraciale de Nouvelle Calédonie.

2347 SUD PACIFIC. Noumea. 1958-March 1974. Monthly in French.

2348 L'UNITE. Noumea. July 1976_- Weekly in French.

2349 LA VOIX DU CAGOU. Noumea. 196?-1975. Weekly in French.

2350 WAYAGUI. Noumea. 1969_. Monthly in French and Maie language. 


\section{CINEMA}

2351 “Film May be Shot in New Caledonia," PIM, 28, no. 10 (May 1958): 65.

French producer M. Decharme in New Caledonia looking over settings for film.

\section{LEGAL ISSUES}

2352 “Deputy Wins Libel Suit,” PIM, 27, no. 2 (September 1956): 77.

Reports judgment against France Australe in favor of a member of Parliament.

\section{THE PRESS}

2353 "From Notes Made in New Caledonia," PIM, 11, no. 5 (December 1940): 27, 29,31 .

Some references to the lack of French newspapers.

2354 Robson, R. W. "From Notes Made in Viti Levu and New Caledonia," PIM, 25, no. 5 (December 1954): 80-81, 129.

Descriptive story contains references to France Australe and its publisher.

2355 "100 Ans de Journalisme: Que se Passait-il en Europe et Surtout en France?" Corail, 51 (January 17, 1963): 14-19.

Article gives historical information on newspapers in French colonies.

2356 “Australian Press Hurts Noumeans' Feelings," PIM, 39, no. 7 (July 1968): 67.

Article reviews press tensions between Noumean and Sydney newspapers and certain radio stations concerning nonattendance of the Noumean press at a military parade.

2357 "New Caledonia Tourist Paper Bites the Dust," PIM, 40, no. 3 (March 1969): 45.

Notes the demise of Noumea Holiday after first issue.

2358 “Battle for the 'Bulletin',' PIM, 41, no. 8 (August 1970): 126.

Reports contention for control of Bulletin du Commerce between independent nickel miners and the Société le Nickel; also information on France Australe.

2359 Thompson, Virginia, and Richard Adloff. The French Pacific Islands: French Polynesia and New Caledonia. Berkeley: University of California Press, 1971. 539 pp.

Occasional mention of New Caledonia periodicals in connection with political activities and in historical references.

2360 Rousseau, Helen. "No Medal for Record Breakers," PIM, 42, no. 10 (October 1971): 64-5.

Article reports at least 17 newspapers and political newsshects currently being published in New Caledonia, including Canaque Awakening, The Caledonian Inland, Le Caldoch, and the new Les Nouvelles.

2361 "Voix du Cagou Closes Down," PIM, 46, no. 10 (October 1975): 28.

Once-popular weekly newspaper closes; newspaper reported under police investigation. 
2362 Wright, Glen. "A Shout of Joy and a Cry of Pain,"' Index on Censorship, 5, no. 4 (Winter 1976): 49-53.

Article on development of press in Pacific includes information on first private newspaper in New Caledonia, (Le Courrier) Illustré de la Nouvelle Calédonie, published in 1878 and 1879.

2363 “New Voice," PIM, 47, no. 9 (September 1976): 31.

Reports new Noumea weekly, $L$ 'Unite (Unity).

\section{RADIO BROADCASTING}

2364 "Broadcast for New Caledonia Residents," PIM, 7, no. 5 (December 1936): 66.

Reports plans for Australian Broadcasting Commission broadcasts to New Caledonia.

2365 “From Notes Made in New Caledonia,"' PIM, 11, no. 5 (December 1940): 27, 29,31 .

Contains some references to lack of newspapers and reliance on radio broadcasts for news.

2366 “New Radio Station in Noumea,” PIM, 14, no. 3 (October 1943): 12.

Reports establishment by American Red Cross of radio station to broadcast to U.S. military forces.

2367 Lader, Lawrence. "Island Programs: Notes on the Army-Operated Network in the Pacific Battle Zone," NYT, December 17, 1944, II-9: 3.

Programming and operations of American forces stations in New Caledonia, the Solomon Islands, the New Hebrides, and New Zealand.

2368 “'Changes in Island Broadcasts," PIM, 24, no. 3 (October 1953): 87.

Frequency changes in several areas, including New Caledonia.

2369 “'Broadcasting in the Pacific," $S P B, 6$, no. 4 (October 1956): 41-45, 56.

Describes broadcasting facilities in New Caledonia and elsewhere.

2370 "New Broadcasting Station for Noumea," PIM, 29, no. 7 (February 1959): 79.

Reports Noumea station's change from shortwave to medium wave.

2371 “Radio Noumea 'Might Suffer Interference'," $P I M, 31$, no. 5 (December 1960): 128 .

On possible interference from a New Zealand Broadcasting Service transmitter.

2372 “'Have You Picked Up Radio Noumea?” PIM, 41, no. 5 (May 1970): 38.

Note on Radio Noumea's expansion of service and installation of transmitter on St. Marie island.

\section{SATELLITE COMMUNICATION}

See also Pacific Islands General

2373 "Un Satellite pour Les Télécommunications de la CPS," France Australe, January 10, 1974, pp. 8-9.

Installation of experimental telecommunication station and PEACESAT Project described; map showing satellite coverage. 
2374 "Hier Aprés-Midi a la C.P.S. Reussite Totale pour la Premiére Liaison Téléphonique Par Satellite," France Australe, January 11, 1974, p. 7.

Discusses New Caledonia-Hawaii link in PEACESAT system; activities; costs.

2375 "French to Introduce Satellite News Soon," PICN, 5, no. 4 (December 1975):

5.

New Caledonian offshore islands expected to have television broadcasts made available via satellite by mid-December.

\section{TELEVISION}

2376 "New Caledonia, Tahiti to Have TV, Too," PIM, 35, no. 11 (November 1964): 63-64.

French government plans for installation of television stations discussed.

2377 "France Gets a Move On (No One Knows Why) With Noumea's Television," PIM, 36, no. 7 (July 1965): 51.

Discusses reasons for government haste in building a television station and resistance to it.

2378 “Australian TV Beats the Local Variety to Noumea's Sets," PIM, 36, no. 11 (November 1965): 40.

Reception of Australian television broadcasts in New Caledonia.

2379 “'It's All 'Go' For French Pacific TV,” PIM, 36, no. 12 (December 1965): 8.

Information on television in New Caledonia and French Polynesia; speculates on cost of licenses.

2380 “TV Extension,” PIM, 40, no. 9 (September 1969): 161.

Reports new TV relay station at Mont Do opened July 14; article relates that television operates about $31 / 2$ hours per day with mainly Paris-originated programs.

2381 "Caledonia Politician Goes on Television-For the First Time," PIM, 41, no. 4 (April 1970): 103.

Caledonian deputy to National Assembly allowed on Noumea television for first time; previously, politicians denied use of television because they were not members of national parties constituted in metropolitan France.

2382 "Television for the Loyalties," PIM, 46, no. 11 (November 1975): 80.

Reviews plans to extend TV coverage to offshore islands. 


\section{New Hebrides}

INDEXES, GUIDES, REFERENCE WORKS

2383 O’Reilly, Patrick. Hébridais Répertoire Bio-bibliographique des NouvellesHébrides. Publications de la Société des Océanistes no. 6. Paris: Musée de l'Homme, 1957. $289 \mathrm{pp}$.

A biographical dictionary; includes journalists.

NEWSPAPERS, PERIODICALS

2384 BRITISH NEWSLETTER. See New Hebrides News.

2385 LE BULLETIN. See Nabanga.

2386 BULLETIN D' INFORMATION. See Nabanga.

2387 BULLETIN D'INFORMATION DE LA RÉSIDENCE DE FRANCE AUX NOUVELLES-HÉBRIDES. See Nabanga.

2388 LE BULLETIN DU COMMERCE DE LA NOUVELLE CALÉDONIE ET DES NOUVELLES-HÉBRIDES. Noumea. 1859-72? Semiweekly, 1859-June 30, 1886; daily thereafter; in French. Available on microfilm, Pacific Manuscripts Bureau.

2389 CORAIL. Noumea. 1961?-1966. Published twice a month in French.

Magazine with news and feature articles; distributed in New Hebrides and New Caledonia.

2390 JOURNAL OFFICIEL: GAZETTE. Port Vila. June 1927—. Monthly.

2391 KOUSURATA. Port Vila. 1974-1975? Monthly in French and English. Predecessor was New Hebrides' Nakamal (1971-74), a monthly published by Société de presse et d'éditions néo-hébridaise.

Three issues of Kousurata published. 
2392 NABANGA. Vila. April 1975-. Biweekly in French and Bichelamar, with occasional English. Published by Service d'Information, Résidence de France. Originally titled Bulletin d'Information de la Résidence de France Aux NouvellesHébrides (1962-April 1975); Bichelamar edition titled Bulletin d'Information (1961January 1974), then Le Bulletin (January 1974-April 1975), issued monthly.

2393 NASONAL PATI NIUS. Vila. 1976- Biweekly in Bichelamar.

2394 LE NÉO-HÉBRIDAIS: JOURNAL FRANÇAIS INDÉPENDANT, POLITIQUE, AGRICOLE ET COMMERCIAL. Port Vila 1909-1942. Monthly; frequency varied. Available on microfilm at University of Hawaii.

2395 NEW HEBRIDEAN VIEWPOINTS. Vila. 1971-. Official publication of the New Hebrides National Party. Quarterly in English and Bichelamar.

2396 NEW HEBRIDES BRITISH SERVICE GAZETTE. Port Vila. March 26, 1968 - Irregular until 1971, then monthly. Previous official gazette was Western Pacific High Commission Gazette (1915-1967), published in Suva, and containing ordinances, administrative changes, etc., for Great Britain's Pacific Colonies: New Hebrides, Gilbert and Ellice Islands, Fiji, British Solomon Islands. Issues of 1940-42 available on microfilm at University of Hawaii.

2397 NEW HEBRIDES' NAKAMAL. See Kousurata.

2398 NEW HEBRIDES NEWS. Vila. 1973? - Biweekly in English and Bichelamar. Published by Information Department, British Residency. Succeeded the biweekly British Newsletter (1955-1973).

2399 WESTERN PACIFIC HIGH COMMISSION GAZETTE. See New Hebrides British Service Gazette.

\section{GOVERNMENT AND INTERNATIONAL AGENCY REPORTS}

2400 Great Britain. British Residency. Information Department. Report. 1971-.

\section{CINEMA}

2401 Eaton, A. M. "Santo Becomes a Cinema Town," PIM, 19, no. 6 (January 1949): 50-53.

Reviews opening of cinema in Santo, New Hebrides.

2402 "French Film Brings Criticism," PIM, 19, no. 9 (April 1949): 54.

Reviews local criticisms of film shown in Vila and Santos.

2403 Regenvanu, Sethy. "New Hebrides Censorship," PIM, 45, no. 9 (September 1974): 25, 29-30.

Letter to PIM editor reported on history of film censorship by Censorship Board.

2404 “Censorship Exchange," PICN, 5, no. 2 (June, 1975): 3.

Presents letters to the editor of PIM on film censorship in the New Hebrides. 


\section{THE PRESS}

2405 “N. Hebrides Paper Suspended,” PIM, 15, no. 9 (April 1945): 8.

Reports suspension of the weekly Le Néo-Hébridais for censorship reasons.

2406 “'100 Ans de Journalisme: Que se Passait-il en Europe et Surtout en France?'” Corail, 51 (January 17, 1963): 14-19.

Article gives some historical information on newspapers in French colonies.

2407 “'New Hebrides Round-Up,” PIM, 36, no. 4 (April 1965): 16.

Reports British Newsletter, produced by the British Residency, will now be distributed every two weeks; previously had been monthly or bimonthly.

2408 “New Hebrides Gets A Political Voice," PIM, 42, no. 10 (October 1971): 45-47.

Reports August appearance of New Hebridean Viewpoints, a quarterly produced entirely by New Hebrideans; also Nakamal (Meeting House), a monthly first out in July.

2409 “News Emphasizes Features, Background,” PICN, 4, no. 3 (May 1974): 11.

Discusses editorial policy, staff, printing of New Hebrides News, published by British Residency.

2410 “New Magazine Appears,”' PICN, 4, no. 4 (September 1974): 13.

Discusses problems on the monthly magazine, Kousurata, devoted to cultural and travel subjects.

2411 “Changes With Islands Press,” PIM, 45, no. 11 (November 1974): 10.

Reports changes concerning Kousurata.

2412 “Travel Magazine Kousurata, Folds,” PICN, 5, no. 1 (February 1975): 15.

Husband and wife editing team fold travel and art magazine after three issues, citing production costs and failure to attract advertising or readership. Also reported in PIM, 46, no. 2 (February 1975): 15.

2413 Matas-Kelekele, Kalkot. “The White Man's Burden,” PIM, 47, no. 7 (July 1976): 23-24.

Reports on Le Néo-Hébridais, a planter's newspaper.

\section{PRINTING}

2414 Ferguson, John A. A Bibliography of the New Hebrides and A History of The Mission Press. 3 volumes. Sydney: Privately printed, 1917, 1918, 1943. 36, 52, 47 pp.

Each volume gives a general bibliography and history of the press. Volume 1: Aneityum, Fituna, and Erromanga, 1849-1909; Volume 2: Tanna, Aniwa, and Efate, 1845-1915; Volume 3: Nguna-Tongoa, Makura, Emao, Epi, Paama, and Ambrym, 1873-late 1920s.

\section{RADIO BROADCASTING}

2415 “"News Broadcast in New Hebrides," PIM, 8, no. 12 (July 1938): 29.

Reports broadcasts of local news, copra prices, and ship movements by an individual radio operator.

2416 Frater, Maurice. " 40 Years in the New Hebrides," PIM, 10, no. 7 (February 1940): 36-40.

Article by a 40 -year veteran of missionary work includes a section on the impact of radio on New Hebrideans. 
2417 Lader, Lawrence. "Island Programs: Notes on the Army-Operated Network in the Pacific Battle Zone," NYT, December 17, 1944, II-9: 3.

Discusses programming and operations of American forces stations in the New Hebrides, New Caledonia, the Solomon Islands, and New Zealand.

2418 "In A Nutshell," PIM, 36, no. 9 (September 1965): 13.

Announces New Hebridean radio station officially opened in September.

2419 “New Hebrides to Go On Air," PIM, 37, no. 8 (August 1966): 86.

Announces British and French Administrations will start joint broadcasting services in August; plans for a 45-minute broadcast four days per week.

2420 "'Aid to Developing Countries," Educational Television International, 1, no. 1 (March 1967): 50-54.

Lists British financial and personnel aid to broadcasting and information services, 1964 to June 1966, with reference to New Hebrides.

2421 “Radio Vila Broadcasts More," PICN, 4, no. 1 (August 1973): 14.

Information on schedule, program content, and personnel of New Hebrides Broadcasting Service.

2422 McNeil, John. "Broadcasting in the New Hebrides," $S P B, 24$, no. 1 (1974): 23-24.

A short article detailing the history of broadcasting in the New Hebrides and present difficulties, mainly funding.

2423 “'Radio Vila Keeps Cyclone Pamela Watch," PICN, 4, no. 3 (May 1974): 11.

Discusses role of radio staff during hurricane watch.

2424 "Radio Vila to Explain Political, Social Changes," PICN, 5, no. 1 (February 1975): 15.

Reports initiation of political programs to familiarize listeners with constitutional and social changes.

\section{SATELLITE COMMUNICATION}

See also Pacific Islands General

2425 "Discussion Through Satellite," British Newsletter, May 16, 1972, p. 6.

Reviews satellite link between students at University of the South Pacific and University of Hawaii in which New Hebridean student participated.

2426 “PEACESAT Expands," PICN, 5, no. 3 (September 1975): 2.

New terminal for PEACESAT communication system began operation in Port Vila July 14, 1975. 


\section{Niue}

\section{NEWSPAPERS, PERIODICALS}

2427 NIUE ISLAND GAZETTE. Alofi. 1966-. Official gazette; published irregularly; in English and Niue languages.

2428 NIUE NEWSLETTER. Alofi. October 21, 1953-February 15, 1966. Generally published biweekly in English and Niuean by Resident Commissioner's Office. Available on microfilm at University of Hawaii.

2429 TOHI TALA NIUE. Alofi. 1953-. Biweekly in Niuean, 1953-1965; weekly in Niuean and English from 1966-1976; biweekly from May 1976 on. Present publisher: Information Office of the Niue Government; previously, Community Development Office, Niue Government.

\section{CINEMA}

2430 " 'Free-for-All' Censorship Comes to an End on Niue," PIM, 36, no. 11 (November 1965): 87.

Reports new law restricting those who might attend censorship screenings of films.

2431 Brown, J. Edward. "'Tarzan the Ape Man'- Who Brings Back Fond Memories," PIM, 41, no. 5 (May 1970): 85.

Reviews popular films viewed in Niue. Article mentions February 1949 as date of first commercial film viewed in Niue.

2432 Anaki, Dean. "Spoiling Niue's Name," PIM, 41, no. 7 (July 1970): 35.

Letter to PIM editor criticizes J. Edward Brown's article on Niue's commercial film activity.

\section{COMMUNICATION RESEARCH}

2433 Carney-Rowan, Sandra. "Niue: Voices of Change. A Study of the Role of Communications in Population Change on Niue." Honolulu: East-West Center, Communication Institute, $1973.23 \mathrm{pp}$.

Traces the historical development of mass media on Niue Island and the impact of media on social and demographic change. 


\section{EDUCATIONAL MEDIA}

2434 Thornton, Jack. "School Journals for Polynesia," PIM, 22, no. 9 (April 1952): 66-67.

Describes literature produced by School Publications Branch, New Zealand Education Department, for distribution in Niue and other island areas; discusses editing, production, and distribution.

\section{GOVERNMENT INFORMATION ACTIVITIES}

2435 “Tohi Tala Niue Update,” PICN, 4, no. 2 (December 1973): 12.

On the editorial policy, staff, circulation, and history of the information office of Niue.

2436 Carney-Rowan, Sandra. "Niue Information Office Covers a Referendum," PICN, 5, no. 1 (February 1975): 5.

Describes activities of Niue information office in months preceding September 1974 referendum on internal self-government.

\section{RADIO BROADCASTING}

2437 “'Broadcasting in the Pacfiic,"' $S P B, 6$, no. 4 (October 1956): 41-45, 56.

Describes broadcasting facilities in Niue and other island areas.

2438 “There's a Bright New Night Life on Niue," PIM, 39, no. 4 (April 1968): 61.

Reports government purchase of radios for resale to island residents to promote listening to new radio station.

2439 Coleman, H. A. "Radio Broadcasting in Niue," $S P B, 19$, no. 1 (1969): 31-35.

Discusses history of Radio Niue, listenership survey, plans for expansion.

2440 "Tuning In on Niue," New Zealand Listener (Wellington), no. 1552 (July 1969): 4.

Reviews impact of radio on Niue life.

2441 Douglas, Hima. "Radio Broadcasting in Niue," SPB, 24, no. 2 (1974): 29-31.

Review of introduction of regular radio broadcasting in Niue in late 1960 s. Article condensed in $A B U$ Newsletter, no. 108 (September 1974): 23-24.

\section{SATELLITE COMMUNICATION}

See also Pacific Islands General

2442 Spooner, R. G. Satellite Station-ZKNA. Annual Report to Director of Education, June 4, 1975. Niue Government. 8 pp.

Reports beginning operations of satellite station on Niue, staff, license, publicity and programming, participants, benefits of PEACESAT programs, statistics, and evaluation and recommendations.

\section{TELEVISION}

2443 “'Niue's Only Telly Fan,” PIM, 42, no. 9 (September 1971): 43-45.

Short item on the owner of the only television set on Niue and his reception from Hawaii and American Samoa. 


\section{Norfolk Island}

NEWSPAPERS, PERIODICALS

2444 NORFOLK ISLAND GAZETTE. See Norfolk Island Government Gazette.

2445 NORFOLK ISLAND GOVERNMENT GAZETTE. Kingston?, Norfolk Island. January 22, 1937__. Published irregularly. Previous title: Norfolk Island Gazette (1937-1942). Microfilm copy available at University of Hawaii.

2446 NORFOLK ISLAND MONTHLY NEWS. See The Norfolk Islander.

2447 NORFOLK ISLAND NEWS. See The Norfolk Islander.

2448 NORFOLK ISLAND NEWS. n.s. May 26, 1975-January 12, 1976. March 1976_. Published weekly (1975-January 1976), then monthly (March 1976-).

2449 NORFOLK ISLAND NEWS EDITION. See The Norfolk Islander.

2450 NORFOLK ISLAND NOTICES AND NEWS. See The Norfolk Islander.

2451 NORFOLK ISLAND PIONEER. 1880s? Copies held in Mitchell Library, Sydney.

2452 NORFOLK ISLAND TIMES. See The Norfolk Islander.

2453 NORFOLK ISLAND WEEKLY. See The Norfolk Islander.

2454 NORFOLK ISLAND WEEKLY NEWS. See The Norfolk Islander.

2455 THE NORFOLK ISLANDER. August 6, 1965-. Weekly in English edited and published by Tom and Tim (Mr. and Mrs.) Lloyd. Paper originally established as Norfolk Island Weekly News (May 27-October 14, 1932), available on microfilm, Pacific Manuscripts Bureau; Norfolk Island Monthly News (1933?), Norfolk Island Times (May 31, 1933-September 25, 1935), incomplete set available on microfilm, Pacific Manuscript Bureau; Norfolk Island Weekly (January 22, 1937-November 26, 1943); Norfolk Island News Edition (June 17, 1949-1951); Weekly Island News (October 5, 1951-1952); Norfolk Island Notices and News (August 7, 1958-October 1958); Norfolk News (October 16, 1958-July 29, 1965), published by administration. 
2456 NORFOLK NEWSLETTER. Canberra. July 1971-March 1974. Monthly. Published by Australian Department of External Territories (July 1971-December 1972) and by Department of the Capital Territory (February 1973-March 1974).

\section{THE PRESS}

2457 "Newspaper for Norfolk Island," PIM, 3, no. 1 (August 1932): 11.

Notes establishment of Norfolk Island Weekly News.

2458 “Norfolk Island Weekly Times," PIM, 5, no. 10 (May 1935): 17.

Mentions an article about the Norfolk Island Times which was published in the Sydney Morning Herald.

2459 "Norfolk Island Knows The News Now," PIM, 7, no. 12 (July 1937): 44.

Reports establishment of Norfolk Island Weekly to succeed earlier newspaper, Norfolk Island Times.

2460 “'Norfolk Island's New Newspaper," PIM, 19, no. 12 (July 1949): 36.

Reports paper started by (A. S.) Gazzard (the Norfolk Island Weekly) in late 1930s ceased publication during war; reviews Norfolk Island News Edition, a weekly started in June.

2461 “All The News Fit To Print," PIM, 29, no. 2 (September 1958): 82.

Brief notice of Norfolk Island Notices and News, first published by the government of Norfolk Island in August 1958.

2462 “Travel," PIM, 36, no. 5 (May 1965): 127.

Announces weekly newspaper, The Norfolk Islander, will be published by Tom Lloyd-the first Norfolk Island printer; currently island is served by Norfolk News, a weekly administration news sheet.

\section{3 “In A Nutshell," PIM, 36, no. 8 (August 1965): 16.}

Reports Norfolk Islander's first issue due in August; paper will be 16-20 pages. Norfolk News will cease publication.

2464 “Folded," PIM, 45, no. 7 (July 1974): 33.

Notice of closing of Norfolk Newsletter, which was published by the Australian Department of the Capital Territory.

2465 “Norfolk Island News Makes Debut," PICN, 5, no. 3 (September 1975): 1, 7.

Reviews weekly tabloid newspaper, first published on May 26, 1975.

2466 “Tom Lloyd Notes Role of Press on Norfolk," PICN, 5, no. 3 (September 1975): 6.

Review of ideas of Tom Lloyd, co-editor and publisher of The Norfolk Islander.

\section{RADIO BROADCASTING}

2467 "No More Isolation: What Pacific 'Listeners', Want-Noises of the City," PIM, 1, no. 10 (May 1931): 9.

Short rhapsodic piece by Norfolk Island correspondent extolling the joys of having a radio to break the sense of isolation.

2468 “NI's Radio Station Under Fire," PIM, 33, no. 1 (August 1962): 131.

Reports Norfolk Island Administration planning to extend broadcasting service; international news now is the reading of $\mathrm{ABC}$ broadcasts from previous evening. 
2469 "In a Nutshell," PIM, 35, no. 1 (January 1964): 116.

Reports radio station VL2NI increased in power in November 1963; radio station rebroadcasts Radio Australia news followed by the local news on Monday to Friday mornings.

2470 “Jolly Roger Flies Over Norfolk,” PIM, 37, no. 12 (December 1966): 17.

Reports unofficial radio broadcasting on Norfolk in October 1966.

2471 "Frantic Phil Socks It to 'Em," PIM, 40, no. 2 (February 1969): 37.

Reviews history of Norfolk Island radio station; announces a Broadcasting Board will soon manage station.

\section{SATELLITE COMMUNICATION}

See also Pacific Island General

2472 “Norfolk Service Club Eyes Satellite Link," PICN, 4, no. 4 (September 1974):

12.

Norfolk Island Lions Club expresses interest in obtaining pan-Pacific satellite link.

\section{TELEVISION}

2473 "First Television Picked Up on Norfolk Island," PIM, 35, no. 1 (January 1964): 40.

Owner of Norfolk Island's only television set receives programs from Australia. 


\title{
Ocean Island
}

\author{
NEWSPAPERS, PERIODICALS
}

2474 PAPER NAUTILUS. April 1967-? Monthly in English.

THE PRESS

2475 “And Now a Newsletter from Ocean Island," PIM, 38, no. 6 (June 1967): 38. Information on a monthly newsletter, Paper Nautilus; publishes overseas and local news, sports, poetry and stories, reviews, movie program, local tide information. 


\section{Papua New Guinea}

\section{INDEXES, GUIDES, REFERENCE WORKS}

2476 Papua New Guinea. Administrative College. Government Publications of Papua New Guinea: A Quarterly List of Titles Received by the Library of the Administrative College of Papua New Guinea.1968-. University. Library. Current New Guinea Periodical Publications: A Preliminary Checklist. 1968.15 pp.

2478 Papua New Guinea Handbook, 8th ed. Sydney: Pacific Publications, 1976.

\section{BIOGRAPHIES}

2479 “Gordon Thomas, NG's Veteran Talk-Talker, Passes On,” PIM, 37, no. 8 (August 1966): 9-10.

Obituary of Gordon Thomas (1890-1966), former editor of Rabaul Times.

2480 Thomas, Edward Llewellyn Gordon. "Rabaul-1942-1945." Available on microfilm, Pacific Manuscripts Bureau.

An account of four years as a prisoner of war of the Japanese written by editor of Rabaul Times.

2481 Miscellaneous papers. January 23, 1942-June 3, 1966. Available on microfilm, Pacific Manuscripts Bureau.

Thomas was editor of Rabaul Times, 1925-27 and 1933-42; papers contain writings concerning his captivity in World War II, correspondence about Emma Kolbe; originals deposited at Department of Pacific History, Australian National University.

\section{NEWSPAPERS, PERIODICALS}

2482 ARAWA BULLETIN. Arawa, Bougainville. December 1971? - In English. Published twice a month up to 1976, now weekly.

2483 AUSTRALIAN DIGEST. See Australian Government Digest. 
2484 AUSTRALIAN GOVERNMENT DIGEST. Canberra. 1973—. Previously title varied: Australian Government News (January 1969-1971); then Australian Digest (1971-1973), which was published bimonthly in English. Pidgin-language edition titled Nius Long Gavman Bilong Australia (January 1969-1971), was distributed quarterly.

2485 AUSTRALIAN GOVERNMENT NEWS. See Australian Government Digest. 2486 AUSTRALIAN EXTERNAL TERRITORIES. Canberra. 1961-1972. Frequency varied. Titled varied: Australian Territories (1961-1970).

Contains articles on Northern Territory, Norfolk Island, and Papua New Guinea.

2487 AUSTRALIAN TERRITORIES. See Australian External Territories.

2488 BLACK AND WHITE. Port Moresby. December 1966-1969. Monthly.

2489 BOUGAINVILLE NEWS. Kieta. July 1970_. Monthly.

2490 BRITISH NEW GUINEA GOVERNMENT GAZETTE. See Papua and New Guinea Gazette.

2491 BUKA NEWS. Bougainville. 1948-? In Pidgin.

2492 FOCUS NEW GUINEA. Port Moresby. April 1971-? A monthly in English.

Politics and news magazine.

2493 GARAMUT. Lae. October 11, 1947-? Frequency undetermined. Published in Pidgin by Department of Education.

2494 GOVERNMENT GAZETTE; BRITISH ADMINISTRATION OF GERMAN NEW GUINEA. Rabaul. October 1914-November 1919. Monthly. Title varied in 1918 to Rabaul Gazette. Available on microfilm, Pacific Manuscripts Bureau.

2495 HARI DINA. June 1950-? Monthly in Pidgin. Published by the Hanuabada Social Club in Pidgin.

Provides news, public health, and education articles.

2496 HIRI. Konedobu. January 1976_. Monthly publication of the Office of Information.

Distributed overseas to provide general information about Papua New Guinea.

2497 INSIDE MORESBY. See Inside New Guinea.

2498 INSIDE NEW GUINEA. Boroko. 1969?-1972? Weekly. Title varied to Inside Moresby in 1969.

2499 KIETA NEWS. Bougainville. 1928? Mimeographed newspaper published at Kieta Radio Station. Other publication details unavailable.

2500 KUNDU. Vunapope, New Britain. May 1968-January 1969. Published monthly by the Catholic Mission Press in Pidgin and English.

2501 LAE COURIER. See Papua New Guinea Post-Courier.

2502 LAE NIUS. Lae. 1974_ _ Published twice weekly in English.

General news concerning Lae and Morobe Province. 
2503 LAGASAI. Kavieng, New Ireland. 1947-48. Weekly in Pidgin. Partial set of issues available on microfilm, Pacific Manuscripts Bureau.

2504 LAUNUAT. See Launuat-Lagasai.

2505 LAUNUAT-LAGASAI. Kavieng, New Ireland. January 1972-1973? Bimonthly in Pidgin. Published by Department of Social Development and Home Affairs. Previously titled Launuat (1970-1971), with Pidgin and English articles.

2506 MOROBE NEWS. Wau, Rabaul, Lae. January 1941-January 1942. Weekly. 2507 MORESBY ARMY NEWS SHEET. 1941-194? A weekly published by the Army Education Service.

2508 NEW GUINEA AND AUSTRALIA, THE PACIFIC AND SOUTH-EAST ASIA. Sydney. 1965-. Quarterly in English. Published by Council on New Guinea Affairs.

2509 NEW GUINEA HIGHLANDS BULLETIN. Goroko. 1960-1971? Quarterly. Issues for 1960-1969 are held by University of Queensland, Brisbane and by University of Papua New Guinea.

2510 NEW GUINEA TIMES-COURIER. See Papua New Guinea Post-Courier.

2511 NEWSBEAT. Rabaul. February 1970 — Monthly in English.

A news journal with some political articles.

2512 NEWS REVIEW: PAPUA-NEW GUINEA. 1971-? Frequency not determined. In English. Published by Independent New Guinea News Service.

2513 NIEUW GUINEA STUDIEN. Den Haag. January 1957-October 1962. A quarterly publication. Succeeded Tijdschrift "Nieuw-Guinea" (June 1936-March 1956), a bimonthly (frequency varied).

2514 NILAIDAT. Boroko. 1968?-1972. Monthly.

A student paper at University of Papua and New Guinea.

2515 NIUS BILONG YUMI. Konedobu. 1959—. Semimonthly in Pidgin. English-language edition also, titled Our News. Published by Papua New Guinea Office of Information.

2516 NIUS LONG GAUMAN BILONG AUSTRALIA. See Australian Government Digest.

2517 NU GINI TOKTOK. Port Moresby. October 1962-September 1970. Monthly in Pidgin. Incorporated Pidgin English News, (publishing details not available).

2518 OUR NEWS. See Nius Bilong Yumi.

2519 PAPUA AND NEW GUINEA AGRICULTURAL GAZETTE. See Papua New Guinea Agricultural Journal.

2520 PAPUA AND NEW GUINEA AGRICULTURAL JOURNAL. See Papua New Guinea Agricultural Journal. 
2521 PAPUA AND NEW GUINEA GAZETTE. Port Moresby. 194?-September 15, 1975. Weekly; irregularly published. Previously titled: Territory of Papua Government Gazette (September 1906-December 1940), available on Pacific Manuscripts Bureau microfilm; British New Guinea Government Gazette (January 1903-August 1906), available on Pacific Manuscripts Bureau microfilm.

2522 PAPUA AND NEW GUINEA NEWS. 1968? Biweekly. Other publication details unavailable.

2523 PAPUA AND NEW GUINEA NEWSLETTER. Canberra. 1967-1973. Published biweekly by the Australian Department of External Territories.

2524 PAPUA AND NEW GUINEA VILLAGER. Port Moresby. 1950-May 1960. A monthly publication of the Department of Education.

2525 PAPUA NEW GUINEA AGRICULTURAL JOURNAL. August 1971- A quarterly. Title varied to Papua and New Guinea Agricultural Journal. Succeeded Papua and New Guinea Agricultural Gazette (19?-1941; 1953?-196?).

2526 PAPUA NEW GUINEA POST-COURIER. Port Moresby. June 30, 1969 -. Published five days a week in English. The Papua New Guinea Post-Courier was created by the merger of the South Pacific Post (September 1950-June 1969), published tri-weekly in Port Moresby, and the New Guinea Times-Courier (June 1959-February 1969), published weekly in Lae. Issues of the South Pacific Post are held by the University of Queensland, Brisbane. The New Guinea Times-Courier was created by a merger of the Rabaul Times (1925-January 1942; new series 1957-1959), published weekly in Rabaul and Lae, and the Lae Courier (1957?-1959), published weekly in Lae.

2527 PAPUAN COURIER. Port Moresby. January 1913-January 1917. Monthly. Succeeded Papuan Times and Tropical Advertiser (January 28, 1911-January 1917), monthly.

2528 PAPUAN TIMES. Port Moresby? 1948-? Weekly published by Kwato Extension Association.

2529 PAPUAN TIMES AND TROPICAL ADVERTISER. See Papuan Courier.

2530 PAPUAN VILlAGER. Port Moresby. February 1929-November 1941. Monthly. Published by the Government Printer. Collection at University of Papua New Guinea.

2531 PIDGIN ENGLISH NEWS. See Nu Gini Toktok.

2532 PNG NEWSLETTER. Konedobu. 1967—. Published biweekly by the Office of Information.

Contains political and economic news.

2533 RABAUL GAZETTE. See Government Gazette; British Administration of German New Guinea.

2534 RABAUL NEWS. September 21, 1946-1949? Weekly. 
2535 RABAUL RECORD. March 1916-1918. Monthly.

2536 RABAUL TIMES. See Papua New Guinea Post-Courier.

2537 SOUTH PACIFIC POST. See Papua New Guinea Post-Courier.

2538 TERRITORY OF PAPUA GOVERNMENT GAZETTE. See Papua and New Guinea Gazette.

2539 TIJDSCHRIFT “NIEUW-GUINEA.” See Nieuw Guinea Studien.

2540 TORRES STRAITS AND NEW GUINEA GAZETTE. Thursday Island. January 1888-1890? Weekly. Published by the Island News Company Ltd.

2541 TRANSMITTER. Port Moresby. August? 1975—. Published monthly by the National Broadcasting Commission of Papua New Guinea.

2542 UNI TAVUR. Port Moresby. 197? — . Frequency not available. Published by journalism students at the University of Papua New Guinea.

2543 UNITED NEWS. Port Moresby. October 1971-? Published twice a month in English, Pidgin and Motu by the United Party.

2544 WANTOK. Wewak. August 5, 1970-. Biweekly in Pidgin published by Wantok Publications, Inc. Became weekly in 1977 with editions in following languages: Ailans Nius, Madang Nius, Enga Nius, Sepik Nius.

\section{GOVERNMENT AND INTERNATIONAL AGENCY REPORTS}

2545 Territory of Papua and New Guinea: Miscellaneous Typescript Reports, 1952-1959. "Report on 'Mass Communications' to his Honor the Administrator and the Public Service Commissioner from Committee of Enquiry." Port Moresby, July 9, 1959. 84 pp. Pacific Manuscripts Bureau microfilm PMB 608, item three.

A report on the communication needs and existing services of Papua New Guinea; covers cinema, broadcasting, newspapers, and government public information activities.

2546 International Bank for Reconstruction and Development. The Economic Development of the Territory of Papua and New Guinea. Baltimore: Johns Hopkins Press, $1965.468 \mathrm{pp}$.

Report of an economic survey mission organized by the Government of Australia to undertake a general review of the economic potential of Papua New Guinea and make recommendations in planning a development program; chapter six, on manpower and education, discusses radio and television broadcasting.

2547-2557 Papua New Guinea. Office of the Minister for Information. Reports no. 1-11: P.N.G. Broadcasting Authority. Port Moresby: Department of Information and Extension Services. 1973.

2547 Report no. $1.18 \mathrm{pp}$.

Report on the setting up of a single broadcasting authority for PNG. 2548 Report no. 2. 13 pp.

Discussion of objectives of broadcasting in a developing country. 
2549 Report no. 3. 6 pp.

Report by Paulus Arek, Minister for Information, about his study of the broadcasting systems of Indonesia and Malaysia.

2550 Report no. 4. 60 pp.

Precis of submissions of members of the public, associations, and organizations concerning matters to be taken into account in establishing legislation for a PNG Broadcasting Authority.

2551 Report no. 5.4 pp.

Report by Paulus Arek, Minister for Information, on progress to date in planning a broadcasting authority for PNG.

2552 Report no. 6. 14 pp.

Report on existing educational programs, with recommendations for future programs.

2553

Report no. 7.10 pp.

Report on existing rural broadcasting programs, with recommendations for future programs.

2554 Report no. 8.27 pp.

Report on the development of news and current affairs programs.

2555 Report no. 9. 11 pp.

Report on the organization of religious broadcasting.

2556 Report no. $10.28 \mathrm{pp}$.

Report on visit of the Minister of Information on study tour of broadcasting in Wellington, New Zealand.

2557 Report no. $11.38 \mathrm{pp}$.

Report on technical services.

\section{CINEMA}

2558 Tolala. “Territories' Talk-Talk,” PIM, 17, no. 4 (November 1946): 37.

Reports documentary film "Native Earth" first National Film Production sponsored by Department of External Territories.

2559 “'Cheaper Movies for the Islands,”' PIM, 17, no. 8 (March 1947): 58.

Reviews plans of Australian headquarters of MGM to release movies to Pacific Islands, including PNG.

2560 “'Educational Film Screenings in Papua-New Guinea," Colonial Cinema, 6 (June 1948): 35-38.

2561 Halliday, L. "'How Our Films Can Influence Native Communities," PIM, 20, no. 7 (February 1950): 79-82.

Reviews how Hollywood films were accepted by people in various Pacific Islands, including PNG.

2562 “Cinema-Dancehall Opened with Religious Service," PIM, 25, no. 11 (June 1955): 107.

Announces new cinema in Vanau.

2563 "Samoan Setting for Film about Gilberts," PIM, 26, no. 2 (September 1955): 119.

Postscript to listed story is that "Walk into Paradise," produced by Chips Rafferty in New Guinea, was completed. 
2564 “Documentaries to be Made in P-NG," PIM, 26, no. 4 (November 1955): 32.

Australian Department of Interior Film Division producer, Maslyn Williams, is in PNG concerning making local films.

2565 “The Ten Tambus of Papua-New Guinea Film Censorship," PIM, 31, no. 1 (August 1960): 45, 47.

Discusses film censorship in New Guinea, including list of categories considered taboo by the Department of Native Affairs.

2566 "'P-NG Documentary Film to be Made This Year," PIM, 32, no. 1 (August 1961): 115 .

Commonwealth Film unit will make documentary film.

2567 “'Papua-New Guinea to Abolish Film Censorship," PIM, 32, no. 12 (July 1962): 143-44.

Reports arrangements for end of film censorship for Papua New Guineans.

2568 “Films on Australia's Territories," Australian Territories, 6, no. 2 (1966): 38-48.

Reviews documentary films on Australian Territories available for Commonwealth use.

2569 “'PNG Seeks Film,” PICN, 5, no. 3 (September 1975): 2.

Papua New Guinea Office of Information appeals for donations of motion picture film for library.

\section{COMMUNICATION RESEARCH}

2570 Farace, R. Vincent and Lewis Donohew. "Mass Communication in National Social Systems: A Study of 43 Variables in 115 Countries," Journalism Quarterly, 42, no. 2 (Spring 1965): 253-61.

New Guinea included among the 115 countries on which data is reported.

2571 Farace, R. Vincent. "A Study of Mass Communication and National Development,"' Journalism Quarterly, 43, no. 2 (Summer 1966): 305-13.

New Guinea included among countries furnishing data for study.

2572 Frazer, Thomas L. "A Study of Development, Format and Content of the $\mathrm{Nu}$ Gini Toktok, Neo-Melanesian Newspaper of New Guinea to April 13, 1966,' M.A. Thesis, Louisiana State University, 1969. Listed in Journalism Abstracts, 7 (1969): 101.

A review of issues of $\mathrm{Nu}$ Gini Toktok, and its predecessors from October 4, 1962, to April 13, 1966, indicated the newspaper possessed features characteristic of tabloid papers in Australia and that it was undergoing a period of trial and experimentation.

2573 Morris, R. J., M. Amos and E. Mosogo. "Radio Survey-Morobe." Studies in Communication; An Extension Project. Volume 1. Port Moresby: P-NG (Terr.) Department of Information and Extension Services. 1971. 28 pp.

A radio audience survey from Morobe District.

2574 Moulik, Rita, David Duiger, and Anna Poo. "A Study of Communication Networks in Two Papuan Villages.' Studies in Communication; An Extension Project. Volume 3. Port Moresby: P-NG (Terr.) Department of Information and Extension Services. 1971. 12 pp.

Study on the nature and extent of personal communication networks in two selected villages. 
2575 “A Pilot Study in Perception, Central District." Studies in Communication; An Extension Project. Port Moresby: P-NG (Terr.) Department of Information and Extension Services. 1971.28 pp.

Studied how factors such as age, education, sex, occupation, etc., affect people's interpretation or preference of audio-visual materials: styles of printing, preferences of line drawings, detailed line drawings, or photographs, etc.

2576 Wolfers, Edward P. “Non-traditional Campaign Media," Journal of Papua and New Guinea Society, 5, no. 1 (1971): 64-80.

Reviews the use of radio, newspaper, posters and leaflets, etc., by candidates in the 1968 House of Assembly elections in study of social implications of candidates' use of media.

2577 Gwyther-Jones, Roy E. "Study in Communication: Perception," Read, 6, no. 4 (October 1971): 28-32.

Condensation of a series of studies in communication conducted by the Papua New Guinea Department of Information and Extension Services in 1970.

2578 Carney, Sandra. "Broadcast Communication in Papua New Guinea: Medium for Change," Unpublished manuscript. 1972. 22 pp. Available at University of Hawaii Library, Pacific Collection.

Reviews social-demographic, economic, and other factors in Papua New Guinea in respect to use of radio as a means for a variety of social, economic, political changes.

2579 Allen, Bryant J. "A Study of the Reception of Radio Messages in An East Sepik Village." Port Moresby: Department of Information and Extension Services, 1973. $15 \mathrm{pp}$.

Studies how radio messages are received and utilized in villages in PNG.

2580 Williams, D. R. "Science on Radio: A Report on a Survey into the Effectiveness of Four Programmes in the Australian Broadcasting Commission's 'Primary Science' Broadcast Series.' Konedobu: Papua New Guinea Department of Education, $1973.40 \mathrm{pp}$.

2581 National Broadcasting Commission. Program Analysis: NBC National and District Services. 3 pp. n.d. (1974?)

Ten tables of statistics from NBC survey: six tables on content of programs at district stations; three tables on content of programs on the national service; one table on local and overseas program services.

2582 National Broadcasting Commission of Papua New Guinea in association with Department of the Media, Australia. A Listener Sampling of South-East Buka Island, Bougainville District, Papua New Guinea, June 26 to July 2, 1974. A Report on The Findings of the Survey Team. 5 pp., with attachment: Comments and Suggestions, by Ray Newell, Director, Planning and Research Department of the Media, Australia. 5 pp.

Survey reviews demographic information; table of population, by age and sex; languages spoken by sample members; radio reception by national or district service; hours of broadcast of stations heard; methodology of survey; conclusions. Attachment reviews sampling and interviewing methods and problems with conclusions on penetration of media on lifestyle of residents. 
2583 “Our News Surveys 'Reading Audience'," PICN, 5, no. 4 (December 1975): 14.

Comprehensive questionnaire carried in June 15 issue of Our News to attempt a better understanding of its readership.

2584 Noble, Grant, and John Morea. “Effects of Comic Books and Picture-going on Deviant Behavior in Papua New Guinea: A Preliminary Survey,' Psychological Services Report Papers, Paper 207: Influence of Media Violence, July 1976, 26 pp.

Study of amount and type of comics and films which 15-year-old high school students of both sexes were seeing and reading, and how other students evaluated these subjects on basis of socio-metric questionnaire. Results suggest that mass media violence has little influence in Papua New Guinea and that children who are already violent seek out violent mass media.

\section{EDUCATION AND TRAINING OF COMMUNICATORS}

2585 Rangatan, Christian. “Journalist Works at U.N.," Our News, 10, no. 7 (April 1968): 6 .

Reviews training program and work of the writer, a journalist from Lemakot, New Ireland.

2586 "Learning to be Broadcast Officers," Our News, 10, no. 8 (April 1968): 4.

Reviews training program for broadcast officers at the Department of Information and Extension Services.

2587 Gwyther-Jones, Roy E. "Christian Communications Commission," Read, 5, no. 2 (April 1970): 31-32.

Short report on the first meeting of the Christian Communications Commission, February 4-6, 1970; commission was organized to develop and coordinate training programs in Papua New Guinea.

2588 “They Want Media for the Message," PIM, 41, no. 11 (November 1970): 36.

Christian Communication Commission criticizes churches for not making good use of communication facilities and not encouraging the training of Papua New Guineans in their use.

2589 Australian School of Pacific Administration. Practical Communicators' Course Handbook, no. 1-4 (1973), 8-10 pp.

Handbooks used in training courses for officers of the Department of Information and Extension Services of Papua New Guinea.

2590 Watts, Frank. "ABC Activities in the Training of Overseas Educational Broadcasters," Educational Broadcasting International, 6, no. 3 (September 1973): 145-47.

Describes training programs conducted by Australian Broadcasting Commission, 1967-1972; trainees from Papua New Guinea and other Pacific Islands areas.

2591 International Training Institute, Middle Head Centre. Communication Media Support Services Course, 1974. 10 pp.

Course material for training of officers in clerical support services of communication media institutions, particularly those of the Papua New Guinea National Broadcasting Commission.

2592 “NZBC Helps Pacific Students of Journalism,"' $A B U$, no. 105 (June 1974): 16.

Eight students in broadcast journalism from PNG and the Solomon Islands have worked in New Zealand radio newsrooms under foreign aid program. 
2593 “PNG Broadcast Training," PICN, 4, no. 4 (September 1974): 7.

Notice of scheduled broadcast training program sponsored by the South Pacific Commission.

2594 Hosking, R. J. "A Training Course for Trainers," $A B U$, no. 110 (December 1974): 15-17.

Describes basic training course in radio broadcasting held in Port Moresby.

2595 Tedder, James L. O. "Production Training for the Solomons," $A B U$, no. 110 (December 1974): 17-18.

Describes radio production course conducted by Norman McBain of Unesco.

2596 "New Zealand Gives Aid to Train Journalists," PICN, 5, no. 1 (February 1975): 18 .

New Zealand government contributes NZ $\$ 60,000$ to University of Papua New Guinea for establishment of a one-year diploma course in journalism.

2597 “PNG/Solomons News,” PICN, 5, no. 1 (February 1975): 15.

Four-week course to train broadcasters to teach other persons broadcasting skills, held under the auspices of Unesco ABU regional project in Papua New Guinea, reviewed.

2598 “ABU Publishes Training Manual,” PICN, 5, no. 2 (June 1975): 5.

Asian Broadcasting Union publishes Broadcasters Reference Manual for Papua New Guinea National Broadcasting Commission.

2599 "Casserly Conducting Broadcasting Training," PICN, 5, no. 3 (September 1975): 2.

Fr. Pat Casserly, former head of Radio Department, Catholic Communication Institute of Ireland, seconded for five years to train Catholic broadcasters in the Pacific; training given in Papua New Guinea.

2600 “'Eleven Commission Journalists Receive Journalism Diploma," Transmitter, no. 7 (February 1976): 6.

NBC cadet journalists and five from Office of Information are graduated from the University of Papua New Guinea's year-long journalism diploma course; names of graduates given.

2601 “UPI (UPNG) Offers Communication Diploma," Transmitter, no. 7 (February 1976): 5.

University of Papua New Guinea offers a diploma in mass communications for first time.

\section{EDUCATIONAL MEDIA}

\section{Radio}

2602 Grenfall, William J. "Broadcasting in Papua and New Guinea," in Radio in Fundamental Education in Underdeveloped Areas. Paris: Unesco, 1950, pp. 22-24.

Article reviews history of radio broadcasting in PNG from 1940s and the plans of the Australian authorities for broadcasting development there.

2603 “New ABC Broadcast to P-NG Schools,"' PIM, 24, no. 2 (September 1953): 91.

Reports inauguration of weekly in-school educational broadcasts for schools in Papua New Guinea via stations in Port Moresby.

2604 “'Sing a Song of Papaws,” PIM, 34, no. 5 (December 1963): 85.

Reports on Radio Rabaul pre-school activities such as teaching English to children. 
2605 Goodman, L. R., ed. Broadcasting to Schools for Primary Grades. Papua and New Guinea. Education Department. 1965. 96 pp.

A teacher's booklet explaining the use of radio programming for elementary school programs to assist in expanding students' knowledge about the world.

2606 Goodman, L. R. "Education by Radio in Papua and New Guinea: The Australian Broadcasting Commission's Contribution to Social Progress in a Developing Country," EBU Review, Part B, 111 (November 1968): 30.

2607 South Pacific Commission. Regional Training Seminar on Educational Broadcasting: Report and Recommendations. Noumea: South Pacific Commission, 1970. $105 \mathrm{pp}$.

Report on a conference at Suva, Fiji, May 20-June 2, 1970; discusses status of educational broadcasting and makes recommendations regarding authority and operations, language teaching, use in schools, teacher training, and community education; summarizes papers based on experience in Papua New Guinea, Fiji, and the Cook Islands.

2608 Brockhall, J. F. "Radio as an Agricultural Extension Aid in Papua New Guinea," $S P B, 20$, no. 3 (1970): 39-41, 52.

Reviews problems in using radio to assist agricultural extension officers; tables list languages used at each radio station. Reprinted in $A B U$ Newsletter, no. 76 (August 1971): 10-15.

2609 Halesworth, Brian. "Radio Broadcasts for Schools-Some Lessons Learnt," Educational Television International, 5, no. 1 (March 1971): 56-59.

Discusses aspects of writing, producing, and utilizing educational radio programs, based on author's experience in Papua New Guinea.

2610 "Radio-The Cinderella Medium," Educational Television International, 5, no. 3 (September 1971): 189-91.

Discusses some advantages of using radio for educational purposes; includes example in Papua New Guinea.

2611 Jeffery, Peter. "A Radio and Loudspeaker Combination for Schools in Papua New Guinea," Educational Television International, 5, no. 4 (December 1971): 282-85.

Describes receiving equipment used in a system for school broadcasts.

2612 Australian Broadcasting Commission. "Schools Broadcast Seminar, Balob Teachers College, Lae." Report prepared for the Schools Broadcast Seminar at Balob College, Lae, Papua New Guinea, March 1972.

\section{Television}

2613 "New Guinea Aghast at The Cost of Educational TV," PIM, 37, no. 4 (April 1966): 17-18.

Report on various aspects of introduction of ETV in PNG by Professors Derek Broadbent and Douglas Brooke highly criticized in article as too expensive and grandiose.

\section{FREEDOM OF THE PRESS/BROADCASTING}

2614 "In Grip of Canberra: Papua and Publicity," PIM, 6, no. 9 (April 1936): 4.

Reports protests by Papuan Courier against regulations prohibiting the Papua administration from releasing stories or information to newspapers. 
2615 "PIM Editor Not Allowed to Visit Australian Territories," PIM, 16, no. 7 (February 1946): 36.

Editorial note appended to a letter to the editor; reports R. W. Robson denied permission of the government to visit Australian territories.

2616 Robson, R. W. “Censored!” PIM, 16, no. 9 (April 1946): 26-27.

Describes wartime censorship imposed on the press by Australian authorities.

2617 “Press Censorship for NG?" PIM, 20, no. 3 (October 1949): 15.

Reports only department heads in the Papua New Guinea administration are permitted to make statements to the press.

2618 "P-NG Burnt Offerings to the God UNO," PIM, 27, no. 2 (September 1956): 20.

Editorial comment on the Patricia Robertson case; criticizes government public information policies, claiming officials are most concerned about window-dressing for the United Nations.

2619 "Savage Gaol Sentence for Incautious Woman Teletypist," PIM, 27, no. 2 (September 1956): 19-20.

Discusses case of Patricia Robertson, Papua New Guinea Administration employee in local post office, sentenced to three months in jail for "disclosing the contents of an official radiogram" to a Sydney newspaper; Robertson was part-time correspondent of Sydney Sun and filed story containing information about beheadings in a tribal murder that was not in the official news release but was known to her through her official position.

2620 Inder, Stuart. "Seeing the News Through the PRO's Issue Spectacles," PIM, 27, no. 3 (October 1956): 20, 146-47.

Critical article on Papua New Guinea administration public information practices: "A continuous record of mishandling, general abuse and petty bias. . . " Cites examples of suppression; attributes practices to Port Moresby fear of Canberra and Canberra fear of United Nations Trusteeship Council.

2621 “Supreme Court Halves Severe Sentence,” PIM, 27, no. 3 (October 1956): 20.

Reports Supreme Court decision to reduce by half the sentence of Patricia Robertson, convicted of disclosing details of an administration telegram to a newspaper.

2622 "Problems of Film Censorship and Radio Broadcasting," PIM, 31, no. 7 (February 1961): 80.

Reports existing film censorship for Melanesians and developments in types of radio broadcasting.

2623 “' 'Pravda' Man Barred from New Guinea,' The Times (London), March 13, 1964, 12: 5 .

Reports Russian correspondent refused permission to visit New Guinea; no official reason given; government understood to believe Pravda should not be allowed to gather material to support editorial policy hostile to Australia's work in New Guinea.

2624 Nixon, Raymond B. "Freedom in the World's Press: A Fresh Appraisal with New Data," Journalism Quarterly, 42, no. 1 (Winter 1965): 3-14, 118-19.

Data for study includes New Guinea among the 117 countries surveyed.

2625 Chatterton, Percy. "Some Thoughts on the Freedom of New Guinea's Press (and Radio)," PIM, 40, no. 10 (October 1969): 41-43.

Editorial discusses the barring of New Guinea's only newspaper, the Post-Courier, from the House of Assembly press gallery as a possible threat to freedom of the press; comments on government control of the radio system. 
2626 Ryan, John. "Challenges to Privileges Committee," PIM, 40, no. 9 (September 1969): 39, 136.

Post-Courier refused to apologize for repeating text of Maori Kiki's statements that were issued in Australia concerning representation of planters in the House of Assembly; Post-Courier's reporters were to be excluded from the rest of the sessions in the House.

2627 . “P-NG's 'Sunny' Democratic Future Takes a Tumble,"' PIM, 40, no. 10 (October 1969): 31-2, 135.

Continues report of Post-Courier press ban in PNG House of Assembly.

2628 “ 'Expat' Journalists Restricted in Papua New Guinea," PICN, 5, no. 1 (February 1975): 18.

Papua New Guinea government tightens laws on migrants, including expatriate journalists and others who produce newspapers and radio programs.

2629 “'TV Team Denied Bougainville Entry," PICN, 5, no. 4 (December 1975): 15.

Australian Broadcasting Commission television team prevented from entering Bougainville, according to Post-Courier.

2630 “NBC Suppressing News?” Transmitter, no. 7 (February 1976): 7.

Reviews article from the National Review of Melbourne, February 6, 1976. NBC was silent when PNG newspaper-readers anxiously awaited news of the secessionist riots in Bougainville.

2631 “TV Team No Go on Bougainville," Transmitter, no. 7 (February 1976): 8.

Australian Broadcasting Commission TV team prevented from entering Bougainville, ostensibly for failing to meet visa requirements. Political implications reviewed.

\section{GOVERNMENT INFORMATION ACTIVITIES}

2632 Kassa (pseud.). "Radio and Paper Bombers," PIM, 16, no. 12 (July 1946): 38-39.

Describes propaganda activities of Far Eastern Liaison Office in Japanese-occupied New Guinea during World War II.

2633 Freund, A.P.H. “Coast Watchers in New Guinea Jungles," PIM, 17, no. 5 (December 1946): 33-36.

Article contains information on broadcasts by former administration officers during World War II to provide information to those in enemy-occupied territory.

2634 Inder, Stuart. "Wanted: Fewer Official Handouts, and More Background Facts," PIM, 26, no. 1 (August 1955): 69-71, 73-74.

Analysis and comment on coverage of news in Papua New Guinea; includes critique of government public relations practices.

2635 Robson, R. W. "South Pacific Governments and Their Press Relations," PIM, 27, no. 3 (October 1956): 17-18.

Editorial contrasting government public relations offices of Fiji (good) and Papua New Guinea (bad); accuses Papua New Guinea officials of using public relations office as a shelter.

2636 “New Guinea Film is Worth It," PIM, 28, no. 9 (April 1958): 71.

Review of "Papua and New Guinea," a film about Australian government aid to New Guineans.

2637 “The Job of an Information Centre," PIM, 30, no. 6 (January 1960): 121.

Discusses decision to establish United Nations Information Centers in or near New Guinea. 
2638 "What is the Sound of One Hand Clapping?" PIM, 30, no. 7 (February 1960): 23.

Comment on the need for a United Nations Information Center in New Guinea.

2639 “New Guinea In Need of Public Relations," PIM, 33, no. 5 (December 1962): 13.

Comment on the handling of New Guinea news by the Australian press; opines that New Guinea should have a full-time press officer.

2640 Baker, J. C. "The Political Education Program of the Papua-New Guinea Administration," in The Politics of Melanesia: Papers Delivered at the Fourth Waigani Seminar, ed. Marion W. Ward. Canberra: Research School of Pacific Studies, Australian National University, 1970, pp. 36-44.

A government administration training officer describes the administration's education program, including the publication and broadcasting activities of the Department of Information and Extension Services.

2641 “PNG Opens Overseas Information Office," PICN, 5, no. 1 (February 1975): 18.

PNG's first overseas information office opens in Sydney.

2642 Smales, Gus. "PNG Government Takes Over the Pressman's Job But . . . ," PIM, 46, no. 4 (April 1975): 12-13.

Reviews newswriting problems.

2643 “PNG Information," PICN, 5, no. 3 (September 1975): 7.

Brian Amini, a Papua New Guinean, named director of the government's Information Office.

2644 “Communication Committee Formed," Transmitter, no. 7 (February 1976): 1.

Reports formation of the Communication Coordination Committee for integration of media resources for national development; functions reviewed.

2645 Hungerford, Brian. "How the CCC was Born and What It Means," Transmitter, no. 7 (February 1976): 2.

Reviews setting up the Communication Coordination Committee (CCC) to assist extension broadcasting and other media coordinate their efforts in national development, teaching, and planning.

2646 “Magazine Promotes Our Image,” Transmitter, no. 7 (February 1976): 5.

Office of Information has started a monthly publication-HIRI-with overseas distribution aimed at providing factual articles for people interested in PNG.

2647 "Communication Committee Formed in Papua, New Guinea," $A B U$, no. 121 (March 1976): 21.

Government of Papua New Guinea sets up committee to encourage cooperation among mass media and organizations that need media support for developmental projects.

\section{THE PRESS}

\section{General}

2648 A'Beckett, Arthur W. "The Colonial Press," Proceedings of the Royal Colonial Institute, 38 (1906-1907): 54-91.

Lists New Guinea newspapers but deals mainly with those in Australia, New Zealand, and Canada. 
2649 Kluckhorn, Frank L. "Newspapers Follow Our Men Into Jungle; Army Publishes World Events, Features," NYT, April 3, 1944, 8: 4.

Describes publications of U.S. military forces in New Guinea.

2650 "Islands Newspapers: How War and Socialism Has Killed Territories Journals," PIM, 17, no. 9 (April 1947): 59.

Blames lack of newspapers in Papua New Guinea on war and continuing attacks on private business by Australian government.

2651 "New Weekly Newspapers in Islands," PIM, 21, no. 7 (February 1951): 35.

Notes government administration welcomes for newspapers in Papua New Guinea and Western Samoa.

2652 "Frantic Headlines for New Guinea Occurrences," PIM, 23, no. 11 (June 1953): 123-25, 127.

Criticism of Australian press for sensationalized treatment of various events in New Guinea.

2653 “Rabaul Wants More Australian Papers," PIM, 27, no. 12 (July 1957): 25.

Reports discussion at Rabaul Town Advisory Council concerning availability of Australian newspapers.

2654 "Not a Number to Call Their Own," PIM, 28, no. 9 (April 1958): 25.

Short article about lack of home newspaper and mail delivery in Port Moresby and in Suva, Fiji, because of absence of street numbers.

2655 "Australian Press Under Fire in New Guinea," PIM, 29, no. 12 (July 1959): 119,121 .

Notes complaints of New Guinea residents about treatment of news from New Guinea in Australian press; coverage said to be slanted and sensationalized to aggravate racial prejudice.

2656 "The Press In On the Outer," PIM, 31, no. 4 (November 1960): 35.

Note on poor facilities for press in new Legislative Council chambers at Port Moresby.

2657 "Press and the Papuan Pastor," PIM, 32, no. 12 (July 1962): 23-24.

Criticism of Australian press handling of news from Papua New Guinea.

2658 “Anger in New Guinea Over Newspaper Sensationalism," PIM, 33, no. 5 (December 1962): 9.

Discusses concern of European residents of New Guinea about stories in Australian press to effect that New Guineans are dissatisfied with and dislike Europeans.

2659 Galis, K. W. Nieu-Guinea Journalistiek. Bijdragen tot de Taal-, land- en volkenkunde, 's-Gravenhage, d. 199, 2 e afl., 1963, pp. 188-200.

Lists newspapers and periodicals that are from or about West New Guinea.

2660 "Big Press Corps Now Covers New Guinea," PIM, 35, no. 3 (March 1964): $71-72$.

Notes assignment of correspondents by several Australian newspapers and Australian Broadcasting Commission.

2661 "Gordon Thomas, NG's Veteran Talk-Talker Passes On," PIM, 37, no. 8 (August 1966): 9-10.

Obituary of Gordon Thomas (1890-1966), former editor of Rabaul Times. 
2662 Bowman, D. N. “The Press,” Kumul, 1, no. 6 (February 1968): 11.

Concerns newspaper court reporting.

2663 Inder, Stuart. "Editorial," PIM, 39, no. 7 (July 1968): 15-16.

Editorial reviews criticisms of press coverage of Papua New Guinea.

2664 Murray, J. K. "In Retrospect-Papua-New Guinea 1945-1949 and Territory of Papua and New Guinea 1949-1952," Australian Journal of Politics and History, 14, no. 3 (December 1968): 320-41.

Reviews newspaper and broadcasting situation.

2665 Barnes, C. E. "The Wayward Press? Thoughts on the Context . . ," New Guinea, Australia, the Pacific and South-East Asia, 4, no. 4 (December 1969January 1970): 73-74.

Australian Minister of State for External Territories criticizes Australian press for tendency to judge Papua New Guinea on Australian terms; argues Papua New Guinea press should consider the context in which it operates when criticizing government and exercise discretion on statements that could be malicious or untrue.

2666 Voutas, A. C. "Elections and Communications," in The Politics of Melanesia: Papers Delivered at the Fourth Waigani Seminar, ed. Marion W. Ward. Canberra: Research School of Pacific Studies, Australian National University, 1970, pp. 494-508.

A member of Papua New Guinea House of Assembly describes communication problems associated with political organization and electioneering.

2667 Stephen, David. A History of Political Parties in Papua New Guinea. Melbourne: Lansdowne Press, 1972. 178 pp.

Contains scattered references to newspapers, journalists, and party publications.

2668 Franklin, Karl J. “Why a Newsheet?”' Read, 7, no. 1 (January 1972): 22-24.

Missionary relates experiences in producing weekly newssheet in Usa village.

2669 Fitzgerald, John A. Untitled paper prepared for South Pacific Editors' Conference, Suva, Fiji, July 30-August 5, 1972. Honolulu: East-West Center, Communication Institute, $1972.8 \mathrm{pp}$.

Discusses role of news media in Papua New Guinea and their shortcomings, including lack of PNG staff and training and difficulties in gathering news; recommends development of training in places other than Australia.

2670 Sapias, Austin. "Media in Emerging World." Paper prepared for South Pacific Editors' Conference, Suva, Fiji, July 30-August 5, 1972. Honolulu: EastWest Center, Communication Institute, 1972. 3 pp.

Outlines some problems faced by Papua New Guinea and argues that the media-press and radio-have not been fully utilized to the people's advantage; urges more emphasis on public education by mass media.

2671 "Bitter Attack on Australian Press," Tonga Chronicle, November 29, 1973,

2: 2.

Reports Papua New Guinea Chief Minister Michael Somare's criticism of Australian press articles indicating that PNG citizens before independence were "primitives" and would harm the expatriates remaining in the country after independence. 
2672 “'Sapias Named Press Secretary," PICN, 4, no. 2 (December 1973): 12.

Notes Austin Sapias, staff member of Post-Courier, became Press Secretary to the Chief Minister of Papua New Guinea.

2673 Woolford, Don. "Blacks, Whites ... and the Awful Press," New Guinea and A ustralia, the Pacific and South-East Asia, 8, no. 4 (January 1974): 4-26.

Study based on research in the two main commercial newspapers of Papua New Guinea, Papuan Times, later Courier, 1911-17/1917-42, and Rabaul Times, 1925-42, and, to a lesser extent, in the Rabaul Record, 1916-18, and Papuan Villager, 1929-40; outlines ownership and history of newspapers in Papua New Guinea; argues main papers were primarily concerned with advancing the views of the white commercial sector; reviews opinions reflected in and advanced by the papers, especially regarding Papuans and New Guineans, the administration, and the Australian government.

2674 Coppell, W. G. "When the Pen Helped the Sword to Win the War in PNG," PIM, 45, no. 12 (December 1974): 51-52.

Discusses World War II newspapers in Papua New Guinea.

2675 Smales, Gus. “PNG Government Takes Over the Pressman's Job But . . . ,' PIM, 46, no. 4 (April 1975): 12.

Reviews press problems in Papua New Guinea.

\section{Bisnis}

2676 “' 'Bisnis' in New Guinea,”' PIM, 40, no. 12 (December 1969): 143.

Reports new newsletter to give information on the functions of the Business Advisory Services; Bisnis will have some Pidgin articles.

\section{Black and White}

2677 Chatterton, Percy. "Some Thoughts on the Freedom of New Guinea's Press (and Radio)," PIM, 40, no. 10 (October 1969): 41-3.

Article on freedom of the press reports Black and White, which stopped publication recently, sometimes laid itself open to charge of contempt of parliament.

\section{Bougainville News}

2678 Griffin, James. "Bougainville-Secession or Just Sentiment," Current Affairs Bulletin, 48, no. 9 (February 1, 1972): 258-80.

Includes references to Bougainville News, monthly newspaper, and its publisher, Barry Middlemiss.

\section{Buka News}

2679 “'Keen Rivalry Between Pidgin Newspapers," PIM, 19, no. 12 (July 1949): 35.

Describes Buka News, Bougainville, and three other Pidgin newspapers.

\section{The Councillor}

2680 “New Magazine for P-NG Councils,” PIM, 41, no. 3 (March 1970): 119.

Notes first appearance of The Councillor, official journal for members of local councils.

\section{Garamut}

2681 "Niuspepa Bilong Yupela: Welcome to the Lae Garamut," PIM, 18, no. 4 (November 1947): 60.

Reports appearance of Garamut, published in Pidgin at Lae by Department of Education. 
2682 “Tropicalities," PIM, 18, no. 4 (November 1947): 50.

Column of miscellaneous items devotes several paragraphs to comment on Garamut.

2683 “Keen Rivalry Between Pidgin Newspapers," PIM, 19, no. 12 (July 1949): 35.

Describes Garamut and three other Pidgin newspapers.

\section{Guinea Gold}

2684 Wallace, Paul J., comp. Guinea Gold: History, 1942-1946. Sydney: P. J. Wallace, $1971.32 \mathrm{pp}$.

Short history of the newspaper, Guinea Gold, published by the Australian army in New Guinea, November 19, 1942, to June 30, 1946.

\section{Hari Dina}

2685 Territory of Papua and New Guinea. Department of Education. "Hari Dina: A New Guinea News Sheet,' SPB, 1, no. 4 (October 1951): 35-38.

Describes history, contents, production of a monthly vernacular publication produced in a village near Port Moresby.

2686 "A Vernacular Newspaper in New Guinea (the Hari Dina)," Colonial Review, (March 1952): 144-45.

\section{Helper}

2687 Horne, Shirley. "Newspapers of New Guinea: Torch and Helper, Read, 2, no. 3 (July 1967): 3-4.

Background sketch of two religious publications designed to furnish Papuans reading material in English.

\section{HIRI}

2688 “'Hiri, a New Voice from PNG," PIM, 47, no. 4 (April 1976): 23.

Reviews new monthly magazine published by Papua New Guinea government.

\section{Kieta News}

2689 "Big News is Read in Far-off Isles," NYT, May 13, 1928, X-2: 1.

Radio officer at Kieta, Bougainville, monitors world news and publishes it in mimeographed newspaper, Kieta News.

2690 “Where Jungle's Events are News," NYT, September 15, 1929, IX-18: 4.

Describes and quotes from Kieta News, mimeographed newspaper published at Kieta radio station, Bougainville.

\section{Lae Nius}

2691 "Changes with Islands Press," PIM, 45, no. 1 (November 1974): 10.

Announces first appearance of Lae Nius, English-language weekly.

2692 “ 'Little Papers' in PNG Prosper,” PICN, 5, no. 3 (September 1975): 8.

Review of Lae Nius and Wantok. 


\section{Lagasai}

2693 “'Keen Rivalry Between Pidgin Newspapers," PIM, 19, no. 12 (July 1949): 35.

Describes Lagasai, published at Kavieng, and three other papers.

\section{Morobe News}

2694 “'Morobe News Moves to Lae,’'PIM, 12, no. 4 (November 1941): 36.

Reports move of Morobe News from Morobe to Lac following relocation of seat of government administration.

2695 "Confusion in N. Guinea: Effect of Hurried Move From Rabaul and the Cloud's Silver Lining," PIM, 12, no. 5 (December 1941): 2.

Contains references to effect on Morobe News of moving administrative center from Rabaul to Lae.

2696 “Islands Newspapers Suspended,” PIM, 12, no. 9 (April 1942): 30.

Reports suspension of Morobe News and other papers because of war.

2697 Tolala. “Territories Talk-Talk,"' PIM, 16, no. 8 (March 1946): 66.

Reports move of S. Richardson, previously of the Morobe News at Wau and Lae, to Picton Post.

2698 “Newspaper Service in Papua-New Guinea," PIM, 17, no. 1 (August 1946): 66.

Public notice placed by publishers of Morobe News and other newspapers suspended by war; notes lack of printing facilities.

\section{Moresby Army News Sheet}

2699 “'Port Moresby's News Sheet,"' PIM, 13, no. 4 (November 1942): 29.

Brief article on the Moresby Army News Sheet, published by the army in Australian New Guinea.

\section{New Guinea Courier}

2700 “'Lae Welcomes 'New Guinea Courier',' PIM, 28, no. 11 (June 1958): 137.

Short item on establishment of New Guinea Courier.

\section{New Guinea Times-Courier}

2701 “Newspaper Organization in Papua-New Guinea," PIM, 30, no. 1 (August 1959): 128.

Reports discontinuance of the South Pacific Post-owned Rabaul Times and Lae Courier and establishment of New Guinea Times-Courier. Staff from defunct newspapers will continue operations, mail news stories to Port Moresby paper; new paper will be distributed in Lae and Rabaul.

2702 "Melbourne Group Moves into Papua-New Guinea Newspaper El Dorado," PIM, 36, no. 3 (March 1965): 131, 133-34.

Reports purchase by Herald and Weekly Times, Ltd., of controlling interest in South Pacific Post, Times-Courier, and Nu Gini Toktok; history of newspapers in Papua New Guinea; list of shareholders.

2703 “Tropicalities," PIM, 36, no. 3 (March 1965): 21.

Reports on the quality of the South Pacific Post and the Post's 'younger sister' the Lae New Guinea Times-Courier.

2704 “And Two More Bow Out,” PIM, 36, no, 4 (April 1965): 23.

Notes departure of editor of New Guinea Times-Courier. 


\section{Nu Gini Toktok}

2705 Tolala. “'Territories Talk-Talk,” PIM, 33, no. 4 (November 1962): 61.

Reviews first issue of $\mathrm{Nu}$ Gini Toktok from Rabaul; use of "phonetic" spelling of Pidgin criticized as not uniform. Tolala reports that when he tried to introduce Pidgin in the Rabaul Times in the 1930s, government officials criticized the idea and he couldn't do it.

2706 “Melbourne Group Moves into Papua-New Guinea Newspaper El Dorado," PIM, 36, no. 3 (March 1965): 131, 133-34.

Reports purchase of controlling interest in Nu Gini Toktok by Herald and Weekly Times, Ltd.

\section{Our News}

2707 “'Folded," PIM, 45, no. 7 (July 1974): 33.

Reports curtailment of Our News.

\section{Pangu Pati Nius}

2708 Ryan, John. “P-NG's Month in the Political Pressure-Cooker," PIM, 40, no. 3 (March 1970): 29.

Announces Pangu Party will soon publish Pangu Pati Nius, a monthly in Pidgin and English with some Motu. First printing is planned at 5,000 copies.

\section{Papua and New Guinea Agricultural Journal}

2709 “'Agricultural Gazette from P-NG," PIM, 24, no. 2 (September 1953): 127.

Notes resumption of Papua and New Guinea Agricultural Gazette, discontinued upon outbreak of World War II.

2710 “Journal Crushes Time Barrier,” PIM, 29, no. 3 (October 1958): 79.

Short article on delays in publication of Papua and New Guinea Agricultural Journal.

\section{Papua New Guinea Post-Courier}

2711 “Post-Courier Publishes Independence Souvenir,'” PICN, 5, no. 3 (September 1975): 6 .

Special issue printed to celebrate independence day.

2712 "Post-Courier Tops Pacific Island Circulation," PICN, 5, no. 4 (December 1975): 14.

Reports paper's circulation of 22,340, said to be highest in South Pacific.

\section{Papuan Courier}

2713 “The 'Papuan Courier'," PIM, 6, no. 2 (September 1935): 16.

Reports purchase of virtually all stock by $\mathrm{E}$. A. James, editor and publisher.

2714 “'Islands Newspapers Suspended,' PIM, 12, no. 9 (April 1942): 30.

Reports suspension of Papuan Courier and other newspapers because of war.

2715 “Newspaper Service in Papua-New Guinea," PIM, 17, no. 1 (August 1946): 66.

Public notice placed by publishers of Papuan Courier and other newspapers suspended during war notes lack of printing facilities. 
2716 “"The Day 'The Courier' Died," PIM, 28, no. 6 (January 1958): 80-82.

Brief history of E. A. James and the Papuan Courier, published at Port Moresby; emphasizes James's challenge of radio license fees and critical articles that preceded army takeover of his facilities in January 1942.

\section{Papuan Times and Tropical Advertiser/Papuan Times}

2717 “In Contrast to the Villager," $P I M, 45$, no. 5 (May 1974): 85.

Reports that the monthly Papuan Times and Tropical Advertiser, published from 1911 to 1912 in Port Moresby, was the first commercial newspaper in New Guinea; it became the Papuan Times in January 1913.

\section{Papuan Times, n.s.}

2718 “In Contrast to the Villager," PIM, 45, no. 5 (May 1974): 85.

Reports the title of Papuan Times has been used twice for newspapers in New Guinea; first for a monthly published from 1913 to 1917; later for a weekly published by the Kwalo Extension Association in 1948.

\section{The Papuan Villager}

2719 Nelson, H. "The Papuan Villager: A National Newspaper," Papua and New Guinea Society, 2, no. 1 (1968): 79-85.

Reviews history of The Papuan Villager, which began publishing in February, 1929, to assist Papuans in developing national spirit; newspaper ceased publication in 1941 .

2720 Coppell, W. G. "The Papuan Villager: A Milestone and a Memorial to a Scientist," PIM, 45, no. 5 (May 1974): 83-85.

History of development of early newspapers in Papua New Guinea.

\section{Pisin Pepa}

2721 “VE-Day Announced in Pidgin,"’ PIM, 15, no. 12 (July 1945): 60.

Describes May 9, 1945, issue of Pisin Pepa, journal of the Pacific Islands Regiment, a New Guinea battalion, written in Pidgin.

\section{Rabaul News}

2722 “Tropicalities," PIM, 17, no. 12 (July 1947): 43.

Reviews types of articles and the use of Pidgin in Rabaul News.

2723 “Keen Rivalry Between Pidgin Newspapers," PIM, 19, no. 12 (July 1949): 35.

Describes Rabaul News and three other Pidgin newspapers.

\section{Rabaul Times}

2724 "Confusion in N. Guinea: Effect of Hurried Move From Rabaul and the Cloud's Silver Lining," PIM, 12, no. 5 (December 1941): 2.

Contains references to the effects of moving the administrative center from Rabaul to Lae on Rabaul Times.

2725 “Islands Newspapers Suspended," PIM, 12, no. 9 (April 1942): 30.

Reports suspension of Rabaul Times and other newspapers because of war. 
2726 “Newspaper Service in Papua-New Guinea," PIM, 17, no. 1 (August 1946): 66.

Public notice placed by publishers of Rabaul Times and other newspapers suspended during war; notes lack of printing facilities.

2727 Mouton, Jean Baptiste Octave. Personal and Business Papers. 1911-1948. Pacific Manuscripts Bureau microfilm.

Mouton (1866-1946) was owner of the Rabaul Times; papers include correspondence with the paper's manager, J. Hoogerwerff, and its editor, Gordon Thomas, and Mouton's "Memories" in English and French.

2728 “New Newspaper Building for Rabaul," PIM, 27, no. 6 (January 1957): 33.

Short article on new building to house a newspaper and printing enterprise planned by a Ko Kupu and Rabaul group; notes South Pacific Post, Ltd., of Port Moresby to begin publishing Rabaul Times in January 1957.

2729 “Publication of Rabaul Newspaper," PIM, 27, no. 7 (February 1957): 16.

Corrects information regarding publication of Rabaul Times in article published in preceding PIM.

2730 Tolala. "Territories Talk-Talk," PIM, 27, no. 7 (February 1957): 27.

Notes revival of Rabaul Times; gives brief history of original Rabaul Times, 1925-42.

2731 “"Territories Talk-Talk," PIM, 27, no. 9 (April 1957): 25.

Reports appearance of first issue of revived Rabaul Times; reminisces about administration pressures on staff of original paper of that name.

2732 "Newspaper Organization in Papua-New Guinea," PIM, 30, no. 1 (August 1959): 128.

Reports discontinuance of Rabaul Times and Lae Courier and establishment of New Guinea TimesCourier.

\section{Rigu Karamut}

2733 Griffin, James. "Bougainville-Secession or Just Sentiment," Current Affairs Bulletin, 48, no. 9 (February 1, 1972): 258-80.

Contains references to publication of Rigu Karamut, a newspaper by students at Rigu, near Kieta.

\section{South Pacific Post}

2734 “New Newspaper Published in P. Moresby," PIM, 21, no. 3 (October 1950): 18.

Notes first appearance of twice-weekly South Pacific Post; comment on lack of newspapers in Papua New Guinea.

2735 "More Printing-Publishing Service for Growing Territories," PIM, 30, no. 4 (November 1959): 19.

On the merger of South Pacific Post, Ltd., Papua New Guinea publishers, and Pacific Publications Printing Ltd., of Suva.

2736 "Melbourne Group Moves into Papua-New Guinea Newspaper El Dorado," $P I M, 36$, no. 3 (March 1965): 131, 133-34.

Reports purchase of controlling interest in South Pacific Post by Herald and Weekly Times, Ltd.; history of newspapers in Papua New Guinea; list of shareholders. 
2737 “Tropicalities," PIM, 36, no. 3 (March 1965): 21.

Reports on the quality of the South Pacific Post and the Post's 'younger sister' the Lae New Guinea Times-Courier.

2738 “And Two More Bow Out," PIM, 36, no. 4 (April 1965): 23.

Notes departure of editor of South Pacific Post.

2739 "What's the Value of 'Post' Shares?" PIM, 36, no. 8 (August 1965); 129-30.

Reports value of shares of South Pacific Post, Ltd.

\section{Tolai News}

2740 "New Newspaper for the Tolais of New Guinea," PIM, 32, no. 11 (June 1962): 126-27.

Notes appearance of monthly Tolai News.

2741 “Tolai News," PIM, 33, no. 2 (September 1962): 43.

Reports publishing details of Tolai News, bi-lingual (Tolai-English) newspaper from Rabaul.

\section{Torch}

2742 Horne, Shirley. "Newspapers of New Guinea: Torch and Helper," Read, 2, no. 3 (July 1967): 3-4.

Background sketch of two religious publications designed to furnish Papuans reading material in English.

\section{Torres Straits Pilot and New Guinea Gazette}

2743 Coppell, W. G. "Rise and Decline of the Thursday Island Press," PIM, 44, no. 12 (December 1973): 47-51.

Discusses the local and "international" coverage of the Torres Straits Pilot, first commercial newspaper in the New Guinea area, beginning in the late $1880 \mathrm{~s}$; lengthy quotations.

\section{Wantok}

2744 “' 'Wantok' Will Tell the News in Pidgin,” PIM, 40, no. 6 (June 1969): 39.

Reports plans for a Pidgin newspaper, Wantok, to be published twice monthly at Wewak.

2745 Goodey, R. P. "Wantok: The First Year," Read, 6, no. 4 (October 1971): 16-17.

Discusses problems of publishing a newspaper in a developing country; written by editor of Wantok, fortnightly paper in Melanesian pidgin published by Roman Catholic Bishops' Conference.

2746 “' 'Little Papers' in PNG Prosper," PICN, 5, no. 3 (September 1975): 8.

Review of Wantok and Lae Nius.

\section{PRESS/BROADCASTING ORGANIZATIONS}

2747 Takeuchi, Floyd. "PNG Journalists Form New Association," PICN, 6, no. 4 (December 1976): 8-9.

Reports establishment of interim journalists association; 42 journalists and media personnel met in Port Moresby August 24 to start organization. 


\section{PRINTING}

2748 “Mission Printers: Good Work by Lutherans in New Guinea," PIM, 4, no. 9 (April 1934): 18.

Describes output of the Lutheran Mission Printery.

2749 “Papuan Mission Printery,” PIM, 23, no. 1 (August 1952): 83.

Reports installation of new printing equipment at the Roman Catholic Mission on Yule Island.

2750 Papua New Guinea (Terr.) Government Printing Office. A Short History of the Government Printing Office, 1888-1973. Port Moresby, 1971. 15 pp.

\section{RADIO BROADCASTING}

2751 “Wireless License Fees: Papuan Courier Makes Strong Protest," PIM, 4, no. 11 (June 1934): 9.

Quotes Papuan Courier editorial against renewed government demands for payment of license fees by radio listeners in Papua.

2752 “Radio Fees in Papua: Courier Editor Fights Federal Prosecution," PIM, 5, no. 6 (January 1935): 4.

Reports court decision in favor of the editor of the Papuan Courier, who refused to pay radio license fee.

2753 “Islands Broadcasting: Plans by A.W.A.," PIM, 5, no. 10 (May 1935): 5.

Reports Amalgamated Wireless (Australasia), Ltd., dispatch of equipment to establish broadcasting station at Port Moresby.

2754 “'Big Ben in Central Papua," PIM, 5, no. 12 (July 1935): 27.

Feature story on listening to shortwave broadcasts from Great Britain.

2755 “Radio Stations for Pacific: Broadcasts from Suva and Pt. Moresby," PIM, 6, no. 3 (October 1935): 28.

Reports new Amalgamated Wireless broadcast station at Port Moresby nearing completion.

2756 “New Broadcasting Station Opened: 4PM Port Moresby Now in Operation," PIM, 6, no. 4 (November 1935): 75.

Notes opening of first commercial broadcasting station in the South Pacific.

2757 “'Radio News in Motuan," PIM, 14, no. 9 (April 1944): 7.

Reports station 9PA, Port Moresby, plans daily 15-minute broadcast news summaries in Motuan dialect.

2758 “'Papua Chats,'” Newsweek, 24, no. 23 (December 4, 1944): 102.

Describes Geoffry Baskett's one-man operation of 9PA, Port Moresby, which broadcasts 20 minutes a day, three days a week, to 100 receivers.

2759 “'Broadcasts for Papuans: Good Work Through 9PA," PIM, 16, no. 1 (August 1945): 21-22.

Describes development of broadcast programs in Motuan dialect over Port Moresby station.

2760 “Tropicalities," PIM, 16, no. 10 (May 1946): 38.

Reports newscasts in Motuan and Pidgin languages to be broadcast over former army radio station. 
2761 “ABC Radio Station for New Guinea,” PIM, 16, no. 12 (July 1946): 46.

Reports plans of Australian Broadcasting Commission to establish radio stations in New Guinea.

2762 "Voice of New Guinea: Australia Announces Radio Coverage of Her Territories," PIM, 17, no. 1 (August 1946): 12.

Reports Australian Broadcasting Commission plan to install six radio transmitters in Papua New

Guinea; gives background of first station, 9PA in Port Moresby, which provided news broadcasts in

Motuan languages in 1944.

2763 “'Broadcasts for Natives: Plans in Samoa and New Guinea," PIM, 17, no. 8 (March 1947): 58.

Reports plans for use of radio broadcasts for government information programs.

2764 "'Radio for the People: New Installations for Port Moresby," PIM, 18, no. 2 (September 1947): 77.

Reports plans to improve Australian Broadcasting Commission broadcasts in New Guinea.

2765 “Pro-Red Commentary from Port Moresby Radio Station," PIM, 18, no. 10 (May 1948): 23.

Port Moresby correspondent criticizes Australian Broadcasting Commission commentary on foreign affairs broadcast by Port Moresby station.

2766 "Better Radio for N. Guinea: New Shortwave Station at Port Moresby," PIM, 18, no. 12 (July 1948): 55 .

Reports formal opening of Australian Broadcasting Commission shortwave station VLT, which rebroadcasts programs of medium wave station 9PA, Port Moresby.

2767 “'Pidgin Broadcasts from 9PA,'” PIM, 19, no. 3 (October 1948): 89.

Reports addition of half-hour daily broadcast in Pidgin to schedule that includes broadcasts in Papuan languages.

2768 “Radio Receivers for Native Broadcasts," PIM, 19, no. 11 (June 1949): 64.

Reports issuance to Education Departments of radio receivers to enable listeners to hear broadcasts from Port Moresby.

2769 “New Manager for 9PA,” PIM, 21, no. 3 (October 1950): 10.

Profile of Roy Glenister, Australian Broadcasting Commission manager in New Guinea.

2770 “'Short Wave Radio,” PIM, 23, no. 9 (April 1953): 99.

Reports new frequencies in use for shortwave broadcasts from Port Moresby.

2771 “Residents Want Quantity as Well as Quality," PIM, 25, no. 9 (April 1955): 135.

Reports appeal by members of Territorial Legislative Council for expanded news service on Australian Broadcasting Commission station at Port Moresby; editorial statement appended.

2772 “Broadcasting in the Pacific," $S P B, 6$, no. 4 (October 1956): 41-45, 56.

Describes broadcasting facilities in various Pacific Islands areas, including PNG.

2773 “Few Natives Can Enjoy New Guinea Native Radio Sessions," PIM, 27, no. 10 (May 1957): 38-39.

Discusses lack of electricity as an impediment to widespread reception of radio programs; suggests that in view of amounts being spent to develop programming, efforts should be made to provide simple receivers to villages and to make others available at low cost. 
2774 "Now Might Be a Good Time for a Review of Papua New Guinea Radio SetUp,' PIM, 28, no. 5 (December 1957): 99, 101.

Discusses need for revamping Australian Broadcasting Commission Radio Service in Papua New Guinea; outlines criticism of service and suggests improvements.

2775 “They Want Their News More Often," PIM, 29, no. 2 (September 1958): 61, 63.

Discusses controversy over whether Australian Broadcasting Commission station at Port Moresby should broadcast a noon news bulletin.

2776 “'Suggested Local Broadcast for New Guinea D.C.'s,'” PIM, 30, no. 1 (August 1959): 125 .

Reports the advocacy of the District Commissioner of the Tolais of local radio broadcasts to improve relations.

2777 "Problems of Film Censorship and Radio Broadcasting," PIM, 31, no. 7 (February 1961): 80.

Reports existing film censorship and developments in types of radio broadcasting; article reports station 9PA has staff of four Europeans and 12 Melanesians, and broadcasts in English, Pidgin and Motu languages to an estimated 26,000 listeners.

2778 Channell, Douglas. “Pop Tunes are Preferred,” PIM, 31, no. 9 (April 1961): 47.

Channel replies to February 1961 PIM article on radio broadcasting.

2779 “'Rabaul-At Last-Gets Its Own Radio Station,” PIM, 32, no. 3 (October 1961): 116-117.

Reports establishment of a radio station at Rabaul, broadcasting in Tolai, Pidgin, and English.

2780 The World News in Pidgin,' PIM, 32, no. 9 (April 1962): 116.

Reports plans of Father Francis Mihalic to organize a news service in Pidgin.

2781 “Big Papua-New Guinea Expansion in Broadcasting Services," PIM, 32, no. 11 (June 1962): 140.

Discusses plans of the Papua New Guinea Administration and the Australian Broadcasting Commission to expand broadcast services to cover the entire territory and to produce programs in the vernacular languages.

2782 "Papua-New Guinea on Threshold of Dramatic New Radio Development," PIM, 33, no. 7 (February 1963): 33, 35, 37, 39.

Describes improvements made in equipment and programming of the radio systems in New Guinea and discusses acceptance of radio by various tribes.

2783 “In a Nutshell,” PIM, 33, no. 8 (March 1963): 133.

Reports new radio station (VL9CD) in Wewak opening soon.

2784 “'They Listen to Radio Peking," PIM, 33, no. 8 (March 1963): 6.

Reports some Papua New Guinea listeners prefer Radio Peking to the Australian Broadcasting Commission station at Port Moresby.

2785 “'Radio Rabaul Gives Them What They Want,"' PIM, 33, no. 10 (May 1963): $23,25$.

Discusses programs broadcast by Radio Rabaul. 
2786 “'In a Nutshell," PIM, 33, no. 11 (June 1963): 127.

Reports Wewak radio station (VL9CD) very popular; radio sets have been installed at several centers.

2787 “ABC Studios on Schedule,” PIM, 34, no. 5 (December 1963): 20.

Short note on completion of Australian Broadcasting Commission studio at Port Moresby.

2788 “'In a Nutshell,” PIM, 35, no. 9 (September 1964): 119.

Reports opening of new station at Daru (VL8VD) soon; also new studio in Port Moresby opened in September.

2789 Papua-New Guinea. (Terr.) Department of District Administration. Radio Rabaul VL9BR. 1965. 12 pp.

Text in Pidgin.

2790 “ABC Uncertainty Over Role in New Guinea," PIM, 36, no. 3 (March 1965): 26-27.

Discusses Australian Broadcasting Commission consideration of whether to remain in Papua New Guinea and expand services or withdraw and let the Administration radio system take over broadcasting services.

2791 Gibson, J. A. "Radio and Its Functions in Australian Territories," Australian Territories, 5, no. 2 (March 1965): 17-23.

Reviews history of radio since 1945 with emphasis on its use in education, information dissemination, and social contacts.

2792 MacKay, Ian K. "Administration Broadcasting in Papua and New Guinea," Australian Territories, 7, no. 1-3 (1967): 29-32; 7, no. 4-6 (1967): 32-36; 8, no. 1 (1968): 35-38.

Three articles on development of Administration broadcasting in Papua New Guinea; map; illustrations.

2793 “'Radio Bougainville Opens,” Our News, 10, no. 10 (May 1968): 6.

Reviews opening of Administration's eighth broadcasting station, at Kieta.

2794 “'Commercial Broadcasting,"' Papua and New Guinea News, 2, no. 9 (May 2, 1968): 7.

2795 Barrett, Donald. "Administration Radio Out of Tune with Times," South Pacific Post, June 24, 1968, p. 7.

2796 “Future of Broadcasting in Territory," Papua and New Guinea News, 2, no. 13 (June 27, 1968): 9.

2797 Schwimmer, Z. "What are the Objectives of Broadcasting in Papua-New Guinea?" Papua and New Guinea Journal of Education, 5 (June 1968): 48-51.

Reviews value of broadcasting to villagers as seen by anthropologist who observed which programs were liked and understood best by villagers.

2798 “M.H.A. Commends Radio Service," Papua and New Guinea News, 2, no. 14 (July 11, 1968): 6.

2799 "Radio Helps to Bridge the Gap," Papua and New Guinea News, 2, no. 16 (August 8, 1968): 3-4. 
2800 “'Radio Broadcasts Assist Economy," Papua and New Guinea News, 2, no. 17 (August 22, 1968): 3-4.

2801 “Joint Radio Station at Lae by 1970," Papua and New Guinea News, 2, no. 18 (September 5, 1968): 9.

2802 “'Radio Station at Kundiawa Planned," Papua and New Guinea News, 2, no. 19 (September 19, 1968): 6-7.

2803 Arua, Boe. "The ABC in Papua and New Guinea," Australian External Territories, 8, no. 5 (October 1968): 19-29.

Reviews importance of Australian Broadcasting Commission to Papua and New Guinea, with details on specific programs for different audiences.

2804 Murray, J. K. “In Retrospect-Papua-New Guinea 1945-1949 and Territory of Papua and New Guinea 1949-1952," Australian Journal of Politics and History, 14, no. 3 (December 1968): 320-41.

Paper for second Waigani Seminar on the history of Melanesia; includes a short section on broadcasting.

2805 MacKay, Ian K. “'Broadcasting in Papua and New Guinea,' Gazette, 15, no. 4 (1969): $241-48$.

Description of the Australian Broadcasting Commission and Papua New Guinea Administration broadcasting services.

2806 Salisbury, Richard F. Vunamami: Economic Transformation in a Traditional Society. Berkeley: University of California Press, 1970. 389 pp.

Contains references to the impact of radio.

2807 Young, Susan. “Churches Ask for Their Own PNG Radio Station," PIM, 41, no. 3 (March 1970): 136.

Describes efforts of churches of Papua New Guinea and the Solomon Islands to make extensive use of modern communication, including pressing the Australian government for a franchise to permit establishment of broadcasting stations.

2808 “Footnotes," PIM, 41, no. 4 (April 1970): 45.

Reviews the broadcasting language policies of the Australian Broadcasting Commission and the PNG Administration.

2809 “Papua-New Guinea Radio Priorities," PIM, 41, no. 5 (May 1970): 147.

Lists towns in New Guinea where Administration believes radio stations should be built.

2810 “Sweet Reason,” PIM, 42, no. 1 (January 1971): 73.

Radio survey results show listeners would like to hear women radio announcers; Madang and Morobe will soon have government radio stations.

2811 “Nutshell," PIM, 42, no. 2 (February 1971): 39.

Reports construction starting on radio station at Alotau in Milne Bay District.

2812 “In a Nutshell," PIM, 42, no. 12 (December 1971): 33.

Announces that Australian government has decided that a single broadcasting authority should be established in PNG before independence. 
2813 Chatterton, Percy. "Fight for Independent Broadcasting in Papua New Guinea,' PIM, 43, no. 5 (May 1972): 49, 51.

Short history of broadcasting in Papua New Guinea; discusses report by a study group created by the Australian government to explore establishment of a Papua New Guinea Broadcasting Commission.

2814 Sapias, Austin. "Media in Emerging World," Paper prepared for South Pacific Editors' Conference, Suva, Fiji, July 30-August 5, 1972. Honolulu: EastWest Center, Communication Institute, 1972. 3 pp.

Outlines some problems faced by Papua New Guinea and argues that the press and radio have not been fully utilized to the people's advantage; urges more emphasis on public education by mass media.

2815 Naylor, Malcolm. "The ABC in Papua New Guinea: How It Works," SPB, 23, no. 1 (1973): 42-45.

Surveys Australian Broadcasting Commission radio activities in Papua New Guinea with emphasis on programming. Reprinted in ABU Newsletter, no. 98 (August 1973).

2816 “'Modem Tok Tok," PIM, 44, no. 2 (February 1973): 131.

Reports installation of a radio station at Kundiawa, Chimbu, to broadcast programs in Pidgin and vernacular.

2817 “'Radio Station Opened," PIM, 44, no. 3 (March 1973): 19.

Photo story reports radio station in Western Highlands just opened, bringing number of government stations to 12 .

2818 “Radio Stations a 'Sounding' Board," Papua New Guinea Post-Courier, April 2, 1973, 11: 1.

Quotes Papua New Guinea Minister of Information as saying government radio stations can be a sounding board for popular grievances.

2819 Wilcox, Dennis L. "Radio: Its Nation Building Role in New Guinea," Gazette, 19, no. 2 (1973): 107-16.

Reviews difficulties of communication in Papua New Guinea; evaluates Australian Broadcasting Commission and Papua New Guinea Administration radio services and describes their operations; discusses ramifications for other developing countries.

2820 MacKay, Ian K. "The Challenge of the 'Seventies' in PNG," $S P B, 23$, no. 3 (1973): 20-24.

Review of radio broadcasting history in Papua New Guinea.

2821 Carney-Rowan, Sandra. "Interview with Richard Rider: How Can Mass Media Best Serve Different Cultures?’ PICN, 4, no. 2 (December 1973): 4.

Interview with media researcher on field work in Papua New Guinea; emphasizes development and use of broadcasting.

2822 Hadlow, Martin. "A Brief Review of Broadcasting at the Village Level in Papua New Guinea.' Honolulu: East-West Communication Institute, 1974. 10 pp.

Review of history of government broadcasting service in PNG with organizational and technical in formation about district stations as well as programming information.

2823 Hosking, R. J. N.B.C. Broadcasters Reference Manual. Port Moresby: PNG National Broadcasting Commission. 1974.

General and technical information on broadcasting. 
2824 Jackson, Keith. "Radio and Development-The Importance of Listener Access." National Broadcasting Commission Information Paper No. 9. No date (1974?). 7 pp.

Reviews importance of two-way communication between authorities and radio audience toward solving community problems and assisting development. Example of "Dissoo" radio program in Senegal is outlined as well as several participatory radio programs in PNG, "Kivung Bilong Wailis," "Askim na Bekim," etc., show two-way conversation programs can be popular and functional in defining and solving social problems.

2825 “'Liaison Officer for PNG/BC,” $A B U$, no. 102 (March 1974): 36.

Article reviews career of Ian MacKay, Papua New Guinea's ABU Liaison Officer.

2826 MacKay, Ian K. "Broadcasting in Papua New Guinea," $A B U$, no. 102 (March 1974): 5-7.

Reviews history of radio broadcasting in PNG.

2827 "'The Head of the ABU's Newest Member," $A B U$, no. 102 (March 1974): 35-36.

Article reviews career of Sam Piniau, chairman of the PNG National Broadcasting Commission.

2828 Allan, Bryant. "A Study of the Reception of Radio Messages in an East Sepik Village." Port Moresby: Department of Information and Extension Services, 1975. $15 \mathrm{pp}$.

Study of radio reception and use in New Guinean villages.

2829 MacKay, Ian K. "Year of Change for PNG Broadcasting," PICN, 5, no. 1 (February 1975): 16-17.

After one full year of broadcasting, the PNG National Broadcasting Commission has made many changes from its original modeling of the Australian programming system to program for the needs of the Papua New Guinean people; reprint from Papua New Guinea Post-Courier.

2830 '"PNG Radio Develops Active Feedback," PICN, 5, no. 1 (February 1975): 18.

Reviews paper by Martin Hadlow on the effectiveness of radio in the villages of Papua New Guinea.

2831 “Deputy Chairman in Papua New Guinea," $A B U$, no. 113 (March 1975): 31.

Morea Toua appointed deputy chairman of the National Broadcasting Commission; Chris Rangatan acting as director of news and current affairs. NBC gradually developing a network of district stations broadcasting in local languages.

2832 “Somare Controls NBC in Reshuffle," PIM, 46, no. 4 (April 1975): 12.

Personnel changes in news service in PNG.

2833 Woolford, Don. “ . . . How Will the National Radio Fare?” PIM, 46, no. 4 (April 1975): 13, 83.

Papua New Guinea government planning to become more closely involved in news dissemination.

2834 MacKay, Ian K. "Forty Years of Broadcasting in Papua New Guinea," Media Asia, 2, no. 3 (1975): 147-155.

Reviews history of Papua New Guinea radio broadcasting: early programming, wartime activities, development of Government Broadcasting Service in 1961, and formation of the National Broadcasting Commission in 1973. 
2835 “PNG Broadcasting Needs," PICN, 5, no. 3 (September 1975): 3,

6.

Reviews report by Ian MacKay, assistant to the chairman, National Broadcasting Commission of PNG; discusses the requirements of PNG broadcasting, the regulatory and operative powers, and evaluation and research projects.

2836 “'He Was the First Papuan Announcer," PIM, 46, no. 10 (October 1975): 59.

Reviews early career of Morea Hila, a broadcaster for Armed Forces Broadcasting Station 4PM in Port Moresby in 1944.

2837 MacKay, Ian K. "How Radio Came to the Islands," PIM, 46, no. 10 (October 1975): 58-59.

Reviews early history of PNG radio broadcasting.

2838 “ABU Secretariat Established,” PICN, 5, no. 4 (December 1975): 14.

National Broadcasting Commission of Papua New Guinea established Asian Broadcasting Union Secretariat in June.

2839 “'Somare Views ‘News as News',” PICN, 5, no. 4 (December 1975): 14.

Reviews views of Prime Minister Michael Somare on the role of the radio in maintaining national solidarity.

2840 Papua New Guinea National Broadcasting Commission. We the People: The Great Commercial Broadcasting Debate. 1976.

Collection of letters written by the public to the National Broadcasting Commission concerning the introduction of radio advertising.

2841 National Broadcasting Commission. "Low Cost Radio Receivers." Board Information Brief no. 18. February 1976. 1 pp.

Reviews National Broadcasting Commission's search for company to mass produce a low-cost radio receiver for PNG.

2842 “New Minister Wants Changes," Transmitter, no. 7 (February 1976): 5.

Press conference of Dr. Reuben Taureka, minister for information and broadcasting.

2843 “Taureka Talks About Radio," Transmitter, no. 7 (February 1976): 1, 14.

Minister for information and broadcasting, Dr. Reuben Taureka, calls for introduction of listener talk-back programs on provincial radio stations; excerpts from an interview with Taureka are included.

2844 "UNESCO Experts Here to Investigate Broadcasting Proposals (and Other UN News)," Transmitter, no. 7 (February 1976): 3, 4.

Three-man mission from Unesco in PNG to assist the NBC plan major operational changes; aims of the Unesco Mission listed.

\section{SATELLITE COMMUNICATION}

See also Pacific Islands General

2845 “Pacific Network for Satellite," PICN, 2, no. 2 (August 1971): 16-17.

Describes preparations for installation of PEACESAT terminals in Papua New Guinea and Fiji.

2846 Lebasa, Biga. "An Education Via Satellite," Papua New Guinea PostCourier, March 30, 1973, 17: 1.

Feature article on the overall operations of the PEACESAT project and of the Papua New Guinea terminal. 
2847 Engee, P. “The Drum," Papua New Guinea Post-Courier, April 2, 1973, $3: 7$. Column partly devoted to plans for a member of the newspaper's staff to take part in a press conference via satellite.

2848 "PEACESAT and National Development," Transmitter, no. 7 (February 1976): $11,12$.

Reviews the VICSAT (village communication satellite) project in PNG. The PEACESAT system, using small ground terminal, was demonstrated in a village.

\section{TELEVISION}

2849 “'TV for Moresby?” PIM, 26, no. 5 (December 1955): 37.

Notes plans of Wireless Institute of Australia to install experimental television transmitter at Port Moresby.

2850 “Territory Should Look into Television," PIM, 36, no. 1 (January 1965): 48.

Short report of the recommendation of the World Bank that television stations should be built in Papua New Guinea.

2851 “Assembly Asks: Where Does New Guinea Go From Here?" PIM, 36, no. 2 (February 1965): 11-12.

Reports PNG House of Assembly calls for Commission of Inquiry about TV in the Territory.

2852 "Findings on Papua New Guinea Television Due Soon," PIM, 37, no. 1 (January 1966): 20.

Describes activity of Commission of Inquiry into television in Papua New Guinea.

2853 “New Guinea Aghast at the Cost of Educational Television," PIM, 37, no. 4 (April 1966): 17, 19, 23.

Reports results of feasibility study of television for Papua New Guinea; summarizes and criticizes main points of report. Conclusions of original report were that due to its expense, the introduction of television could not be justified except for school or extramural educational use.

2854 “'Report on Television for Papua and New Guinea," A A ustralian Territories, 6, no. 3 (June 1966): 38-44.

Summarizes the findings of the Commission of Inquiry into television.

2855 Jeffery, Peter. "Educational Television in Teacher Education in Papua New Guinea,'" Educational Television International, 4, no. 4 (December 1970): 262-64.

Describes use of closed-circuit television in teacher training programs at Port Moresby Teachers' College and the University of Papua New Guinea. 


\section{Pitcairn}

NEWSPAPERS, PERIODICALS

2856 PITCAIRN ISLAND MISCELLANY. April 16, 1959-. Monthly in English.

THE PRESS

2857 “Can Any Editor Beat This?” PIM, 35, no. 3 (March 1964): 89.

A note on the circulation of Pitcairn Island Miscellany.

2858 Ibbotson, Peter. "Pitcairn Island's Press," Worldwide Newspaper Collecting and Press History, 1, no. 1 (October-December 1970): 13-14.

\section{RADIO BROADCASTING}

2859 “"Pitcairn Calling!” PIM, 8, no. 8 (March 1938): 40.

Describes plan for installation of temporary broadcasting station on Pitcairn for American radio manufacturers.

2860 “'Pitcairn Islanders Talk to US by Radio Tonight," $N Y T$, April 6, 1938, 19: 2. National Broadcasting Company to broadcast program from Pitcairn Island relayed by shortwave.

2861 “"Radio on Pitcairn Upsets Its Youth," $N Y T$, May 24, 1938, 21: 5.

Engineers returning from setting up radio station on Pitcairn say radio communication has made some young people restless.

\section{2 “New Radio Station for Pitcairn,”' PIM, 31, no. 1 (August 1960): 118.}

Reports Pitcairn will soon have 250-watt station, with Thomas C. Christian as radio operator. At present radio for island under control of Governor of Fiji, but radio contacts made via Rarotonga, Cook Islands.

2863 “'Pitcairn Island Feels the Tread of V.I.P. Feet," PIM, 39, no. 4 (April 1968): 85.

Contains short note on former resident returning from Los Angeles with plans for opening a radio station. 


\title{
Solomon Islands
}

\author{
INDEXES, GUIDES, REFERENCE WORKS
}

2864 University of the South Pacific. Solomon Islands Center. Solomon Islands Research Register. Annually since 1972.

Lists completed and ongoing research concerning the Solomon Islands.

NEWSPAPERS, PERIODICALS

2865 BRITISH SOLOMON ISLANDS PROTECTORATE GAZETTE. See Solomon Islands Gazette.

2866 BRITISH SOLOMON ISLANDS PROTECTORATE NEWS SHEET. See Solomon News Drum.

2867 BSI NEWS SHEET. Honiara. See Solomon News Drum.

2868 B.S.I.P. NEWS SHEET. Honiara. See Solomon News Drum.

2869 CENTRAL DISTRICT NEWS. Honiara. 195?-7? Monthly in English. Title varied to Central Solomons News.

2870 CENTRAL SOLOMONS NEWS. See Central District News.

2871 EASTERN NEWS. KiraKira? -1967-. Monthly in English.

2872 KAKAMORA REPORTER. Honiara. March 1970-1975. Monthly in English and Solomon Islands Pidgin.

2873 MALAITA NEWS LETTER. Auki. 1965-7? Monthly in English.

2874 PREVIEW. THE SOLOMON ISLANDS BROADCAST SERVICE. Honiara. July/August 1967—. Bimonthly in English. 
2875 SOLOMON ISLANDS GAZETTE. Honiara. 1975? - Official gazette, issued twice monthly. Previously titled: British Solomon Islands Protectorate Gazette (1968-74). Previous official gazette for the Solomon Islands was the Western Pacific High Commission Gazette (1915-1967), published in Suva, which contained ordinances, administrative changes, etc., for Great Britain's Pacific Colonies: New Hebrides, Gilbert \& Ellice Islands, Fiji, and the British Solomon Islands.

2876 SOLOMON NEWS DRUM. Honiara. February? 1975 — . Weekly publication in English, published by the Solomon Islands Information Service. Title varied: British Solomon Islands Protectorate News Sheet (1955-65); B.S.I.P. News Sheet (1966-71); BSI News Sheet (1972-December 1974), published biweekly in English.

2877 WESTERN DISTRICT NEWS. Gizo. 1970-? Bimonthly in English.

2878 WESTERN PACIFIC HIGH COMMISSION GAZETTE. See Solomon Islands Gazette.

\section{GOVERNMENT AND INTERNATIONAL AGENCY REPORTS}

2879 British Solomon Islands. Department of Post and Telecommunications. Annual Report. Honiara, 1964 -

2880 Kittermaster, A. M. A Report on Information and Broadcasting Services in the Solomon Islands. Commissioned by the Ministry of Overseas Development. September 1970. $109 \mathrm{pp}$.

Report examines policy and organization of official information services in the Solomons and assesses their effectiveness. Sections include: information and broadcasting services; assessment of services; priorities of use of media; information services department; broadcasting information; audio-visual services.

\section{CINEMA}

2881 “Surprise! Surprise!” PIM, 32, no. 5 (December 1961): 115.

Nippon Television Network Corporation (NHK) made TV film "Guadalcanal Today" early this year; film "sensation" in Tokyo.

2882 "Pruning the Tree of Life," PIM, 45, no. 6 (June 1974): 16.

Reports Censorship Board in Honiara cut out offensive portion of movie.

\section{COMMUNICATION RESEARCH}

2883 Kent, Graeme. "Educational and Communications Research, the Place of School Broadcasting by Radio in the Curriculum of Developing Areas: The Solomon Islands." M.Phil. Thesis, University of Southhampton, 1973.

Author interviewed primary-school teachers in the Solomon Islands.

2884 "Communication and National Development in the Solomon Islands.” M.A. Thesis, University of Birmingham, England, 1975.

\section{EDUCATION AND TRAINING OF COMMUNICATORS}

2885 “'SIBS Training Program 'Success'," PICN, 5, no. 3 (September 1975): 7.

Reports four-week training program for Solomon Islands Broadcasting Service. 


\section{EDUCATIONAL MEDIA}

\section{Radio}

2886 “'Solomons Schools Broadcasts," PICN, 2, no. 2 (August 1971): 19.

Information on hours, personnel, programming of Solomon Islands educational radio broadcasting.

2887 Kent, Graeme. "Hello Back There!" Educational Television International, 5, no. 4 (December 1971): 272-74.

Describes teachers' reactions to radio programs broadcast to schools.

\section{FREEDOM OF THE PRESS/BROADCASTING}

2888 "My Lady Nicotine is the Solomons' Ex-screen Star," PIM, 44, no. 9 (September 1973): 43.

Cigarette advertising banned.

2889 “Muzzling Solomons Newsmen,” PIM, 45, no. 6 (June 1974): 9.

Background on government decision to ask for review of all material prior to publication or broadcast.

\section{THE PRESS}

2890 “Army Has Daily in Solomons," NYT, January 17, 1944, 6: 2.

American soldiers in Solomon Islands publish a mimeographed daily newspaper, Torokina Times.

2891 “The Missing 5,000: Latest Development of a Press-made Mystery," PIM, 20, no. 2 (September 1949): 29.

Reviews problems caused by incorrect newspaper story.

2892 Raraka, Henry. Untitled paper prepared for South Pacific Editors' Conference, Suva, Fiji, July 30-August 5, 1972. Honolulu: East-West Center, Communication Institute, 1972. $2 \mathrm{pp}$.

Discusses situation of the press in the Solomon Islands and development of the Kakamora Reporter; asserts development of a Melanesian press is necessary and desirable for national unity and self-identity.

2893 “'A Drum Beat,"' PIM, 46, no. 2 (February 1975): 13.

Announces BSI News Sheet, published by Solomon Islands Information and Broadcasting Services, ceased publication with December 20 issue; new government-run paper will be the Solomon News Drum.

2894 “'Will BSI Hear a 'Boom'?’' PIM, 46, no. 4 (April 1975): 18.

Solomon News Drum will be first Solomon Islands weekly newspaper.

2895 “Government Starts Weekly in Solomons,"' PICN, 5, no. 2, (June 1975): 5.

Solomon News Drum, published by the Solomons Information Service, made its appearance in February 1975.

2896 Richstad, Jim. "Kakamora Reporter to Resume?"' PICN, 6, no. 1 (March 1976): 4 .

Kakamora Reporter, mimeographed newspaper from Solomon Islands, may resume publication in mid-1976, dependent on solution of economic problems.

2897 “Solomons' Kakamora Reporter Dies," PIM, 47, no. 10 (October 1976): 31.

Reports paper edited by Henry Raraka has closed down. 


\section{PRINTING}

2898 “Mission Printing: Excellent Quality of Work," PIM, 3, no. 12 (July 1933): 6. Notes receipt of samples of printing done by Melanesian Mission Press, Guadalcanal; items printed include a Mota-language newspaper, O Sala Ususur.

2899 "Mission Printer and Press Return to Solomons," PIM, 22, no. 12 (July 1952): 101 .

Reports resumption of activities of Melanesian Mission Press, closed in 1942.

2900 “Mission Printing Press Tackles Big Job,” PIM, 25, no. 2 (September 1954): 147.

Reports completion of printing in Bogotu language of the Church of England prayer book and a hymnal by the Melanesian Mission Press.

2901 “They'll Learn How to Print Their Own,” PIM, 29, no. 11 (June 1959): 135.

Reports a Honiara plant will train islanders to use small offset presses to produce forms, textbooks, and pamphlets.

2902 “'Solomons Printers Run Short of Paper,' PICN, 4, no. 3 (May 1974): 8. Reviews Fiji Times article that described paper shortage in Solomon Islands' printery.

\section{RADIO BROADCASTING}

2903 “Extraordinary Radio Tax in Solomons," PIM, 5, no. 2 (September 1934): 10.

Letter to editor from Solomon Islands planter regarding collection of radio tax to support general revenues; editorial comment appended.

2904 “Absurd B.S.I. Radio Regulations,” PIM, 5, no. 7 (February 1935): 44.

Discusses enforcement of radio license fee although the territory operates no radio service.

2905 Lader, Lawrence. "Island Programs: Notes on the Army-Operated Network in the Pacific Battle Zones," NYT, December 17, 1944, II-9: 3.

Programming and operations of American forces radio stations in the Solomon Islands and elsewhere.

2906 “BSIP Government Uses Radio,” PIM, 18, no. 4 (November 1947): 81.

Reports limited use of government radio communication station for local news broadcasts.

2907 “'Honiara Radio Schedules," PIM, 22, no. 5 (December 1951): 117.

Schedule and frequency of the limited broadcasting being done by government radio communication station at Honiara.

2908 “'Honiara Experiments with Broadcasting," PIM, 22, no. 11 (June 1952): 114.

Reports experiments with medium-wave broadcasts by Honiara station; doubts about development.

2909 "Self-help in Honiara: Local Residents Run the Broadcasting Station," PIM, 23, no. 4 (November 1952): 57.

Reports VQO, Honiara, started operations in September; programming includes recorded music, sports and live items from local performers.

2910 “'Honiara Radio," PIM, 24, no. 4 (November 1953): 62.

Notes completion of one year of operation of the volunteer-run Honiara broadcasting station.

2911 “'BSIP Broadcasting Improvements," PIM, 26, no. 7 (February 1956): 95.

Notes operation of new shortwave transmitter at Honiara. 
2912 “The Voice of the Solomons," PIM, 26, no. 11 (June 1956): 119.

Reports request for a grant for construction of a government radio station.

2913 “Broadcasting in the Pacific," $S P B, 6$, no. 4 (October 1956): 41-45, 56.

Describes broadcasting facilities in the Solomon Islands and elsewhere.

2914 “'Stronger Radio Transmission from Honiara," PIM, 27, no. 2 (September 1956): 41.

Reports Honiara radio station, BSIP, almost completed.

2915 Metcalfe, John R. Articles on the Solomon Islands. n.d. Available on microfilm, Pacific Manuscripts Bureau.

Metcalfe, an Australian missionary to the Solomon Islands from 1920 to 1957, wrote articles and broadcast scripts for the Australian Broadcasting Commission.

2916 “'More Broadcasts from BSIP,” PIM, 29, no. 7 (February 1959): 63.

Reports extension of hours and installation of new equipment at Honiara radio station.

2917 "'More and Better Radio in the Solomons," PIM, 31, no. 10 (May 1961): 129-30.

Solomon Islands Broadcasting Service extends service and makes technical improvements.

2918 “Aid to Developing Countries," Educational Television International, 1, no. 1 (March 1967): 50-54.

Lists British financial and personnel assistance to broadcasting and information services in other countries, 1964 to June 1966, with reference to Solomon Islands.

2919 “"595 Radios Presented,” PIM, 40, no. 10 (October 1969): 119.

Photo announcement that Foundation of the Peoples of the South Pacific presented 595 radios to the Solomon Islands.

2920 Miki, William. "The World News in Pidgin English," $A B U$, no. 93 (March 1973): 15-17.

Problems of broadcasting news in Pidgin English in the Solomon Islands.

2921 Tedder, James L. O. “An Expert Visits the Solomons," $A B U$, no. 98 (August 1973): 5-6.

Reports visit of general manager of Melbourne's commercial station $3 \mathrm{KZ}$ to Solomon Islands to assist with development of commercial radio.

2922 . "The Solomon Islands Information and Broadcasting Services-the Broadcasting Section," SPB, 23, no. 4 (1973): 27-32.

Surveys the development of radio broadcasting in Solomon Islands and describes programming and facilities.

2923 "Liaison Officer for Solomon Islands," $A B U$, no. 120 (February 1976): 32.

Richard Hosking is head of Solomon Islands Broadcasting Service (SIBS); article sketches career.

2924 Solomon Islands. Broadcasting Service. SIBS, The Solomon Islands Broadcasting Service: The Solomon Islands Only Advertising Medium. Honiara, Government Printer. n.d. 3 pp. 


\section{Tonga}

NEWSPAPERS, PERIODICALS

2925 CHRONICLE. See Tonga Chronicle.

2926 FETU'U 'O TONGA (Star of Tonga). Nuku'alofa. 1869. Quarterly in Tongan, published by the government.

2927 KALONI KALI TONGA. See Ko E Kalonikali Tonga.

2928 KO E BOOBOO. 1874-82? Monthly in Tongan. Photostatic copies available at Central Archives of Fiji.

2929 KO E BO`OBO`OI. See Tonga Government Gazette.

2930 KO E KALONIKALI TONGA. Nuku'alofa. June 19, 1964-. Weekly, in Tongan; published by Government of Tonga. Title varied: Kaloni Kali Tonga.

2931 KO E TAIMI O TONGA. March 1882-? Tongan-language edition of Tonga Times started.

2932 NIU VAKAI (The Lookout Cocoanut Tree). Nuku'alofa. October 1881-8? Monthly in English.

2933 TAUMUA LELEI. Nuku'alofa. June 1929-October 1939. Monthly, in Tongan; published by Bishop Joseph Blan, S.M., vicar apostelic of the Tongan Islands. Available on microfilm, Pacific Manuscripts Bureau.

2934 TONGA CHRONICLE. Nuku'alofa. June 19, 1964—. Weekly, in English; published by Government of Tonga. Title varied to Chronicle.

2935 TONGA GOVERNMENT GAZETTE. Nuku'alofa. 1876? - . Annually, in Tongan and English. Superseded Ko e Bo'obo'oi (1875-77) Issues for 1968-72 available on microfilm from Photographic Service, New York Public Library.

2936 TONGAN DAILY NEWS. Nuku'alofa. -1959-. News sheet of Tongan court proceedings.

2937 TONGAN TIMES. January 1876-? Monthly in English. 


\section{CINEMA}

2938 “Tonga in Cinerama," PIM, 28, no. 2 (September 1957): 115.

Reports Dudly Film Corporation expected soon for filming; local activities in preparation.

2939 “Japanese TV Team Films Tonga,” PIM, 32, no. 11 (June 1962): 29.

Reports film team from Japan's Nippon Television Network Corporation (NHK) working on TV film in Tonga.

2940 “The Censor Moves In," PIM, 42, no. 4 (April 1971): 32.

Reports Tonga's Board of Censors recently banned 20 out of 220 films brought into the Kingdom during 1970 because of their sexual context; article reviews censorship guidelines.

2941 “Tonga's Film Ban,” PIM, 43, no. 4 (April 1972): 125-26.

Reports banning of six films.

2942 "Film Grading Next Year," Tonga Chronicle, December 19, 1974, 1: 4.

Reviews film-censorship issue; new regulations being considered that would restrict certain films to persons over age 18 or 21 .

\section{COMMUNICATION RESEARCH}

2943 Barney, Ralph D. "Mass Media Roles in Development: A Descriptive Study from Four Developing Areas," Gazette, 19, no. 4 (1973): 222-38.

A study involving the developmental-news content of six newspapers, including the Tonga Chronicle; content analysis produced little evidence of systematic inclusion of development-oriented material in any of the papers.

\section{EDUCATION AND TRAINING OF COMMUNICATORS}

2944 Hugh, E. I. "Tonga: Territorial Training Courses in Agricultural Extension Methods," SPB, 23, no. 1 (1973): 25.

Describes first training course offered in Tonga for agricultural extension personnel.

2945 “Tonga, Western Samoa, Tahiti Get Look at Video Tape," PICN, 4, no. 2 (December 1973): 3.

Describes a travelling videotape-recording training program conducted by Christian Education and Communications Program.

2946 McBain, Norman. "Training in the Pacific," $A B U$, no. 100 (January 1974): 27-28.

Report on broadcast training courses sponsored by Unesco and the South Pacific Commission cenducted in Tonga and elsewhere in 1973.

EDUCATIONAL MEDIA

Radio

2947 “'Schools Broadcast From ZCO Tonga," PIM, 32, no. 6 (January 1962): 113.

Short report on plans for educational broadcasts by Tongan Broadcasting Commission.

\section{FREEDOM OF THE PRESS/BROADCASTING}

2948 "Paper is Upheld in House," Tonga Chronicle, July 11, 1969, p. 3.

Tonga Chronicle's man-in-the-street column challenged and defended in Parliament. 
2949 “'Don't See Eye to Eye on Paper," Tonga Chronicle, July 18, 1969, pp. 1, 8.

Discusses controversy over nature of information published by Tonga Chronicle, including statements of government authorities and parliamentary motions.

2950 “Press Freedom Could Lead to Anarchy," PIM, 40, no. 10 (October 1969): 47-48.

Reports resentment of members of Tonga parliament at criticism appearing in government-subsidized newspapers; proposals for government censors to work at the newspaper and the government-owned radio station.

2951 “Survey of Government Control of Media," PICN, 2, no. 2 (August 1971): $1-4$.

Summarizes the results of a survey by Ralph D. Barney on mass media and leadership attitudes in Tonga, Fiji, and American and Western Samoa.

2952 McClelland, Robert. “A Private and Free Press in Tonga." Working paper prepared at East-West Communication Institute, Honolulu, 1973. 4 pp.

Author reviews problems and conditions encountered in two years as editor of government-owned Tonga Chronicle, including questions of censorship, official direction, and pro-government bias.

2953 "Freedom of the Press," Tonga Chronicle, May 14, 1974, 2: 1.

Editorial defending the actions of the newspaper.

\section{LEGAL ISSUES}

2954 “A 15-year-old Schoolgirl Speaks and Shakes Some Tongan Nobles," PIM, 44, no. 10 (October 1973): 5.

Reports threat of lawsuit against Tonga Chronicle for printing a speech contest entry that called for more democracy in Tonga.

2955 “The Press and the Courts," PICN, 4, no. 3 (May 1974): 2.

Reviews libel case involving a letter to the editor involving a member of the Tongan Legislative Assembly.

\section{THE PRESS}

2956 “"Notice: Offenders Beware," PIM, 30, no. 1 (August 1959): 141.

Short item reporting publication of court proceedings in Tongan Daily News.

2957 “'Tonga Hopes to Improve Its News Service,’ PIM, 30, no. 10 (May 1960): $125,127$.

Reports addition of new equipment to improve news sheets distributed by Tongan government news service.

2958 “Tonga Plans Its First Newspaper,’ PIM, 33, no. 11 (June 1963): 57.

Tongan government plans to publish weekly newspaper.

2959 “"From the Island's Press," PIM, 35, no. 7 (July 1964): 29.

First copies of Tonga's new weekly newspaper sold out rapidly; including 600 copies of Englishlanguage edition and 5,000 copies of Tongan-language edition. 1,000 copies of Tongan-language edition saved for distribution to other islands. Article includes information on early Tongan newspaper, Koe Fetuu O Toga, which appeared in 1869. 
2960 "Work Starts on $£ 170,000$ Hotel in Nukualofa," PIM, 35, no. 8 (August 1964): 21.

Article also reports Tonga's newspaper came under criticism in Parliament because of its publication cost.

2961 "Tonga: Future of the Press," Tonga Chronicle, July 18, 1969, pp. 4, 5.

King Taufa'ahau interviewed on journalism in Tonga and the Tonga Chronicle.

2962 Schwartz, Richard. "Report on the Chronicle to the Government of Tonga." July 1969. $23 \mathrm{pp}$. Available at East-West Center, Communication Institute, Honolulu.

Report on the operations of the Tonga Chronicle prepared by a Peace Corps volunteer editorial adviser; examines editorial, circulation, printing, and advertising operations and makes recommendations.

2963 "Stops Work on the Chronicle," Tonga Chronicle, August 29, 1969, p. 2.

Chronicle staff writer, S. M. Magisi, refused to work following differences with government officials on salary, work, and editorial conditions.

2964 McClelland, Robert S. "The Tonga Chronicle." Paper prepared for South Pacific Editors' Conference, Suva, Fiji, July 30-August 5, 1972. Honolulu: EastWest Center, Communication Institute. 7 pp.

An interview with the King of Tonga regarding the role of the press in Tonga and the official attitude toward the administration's relationship with the Tonga Chronicle; covers press law, private enterprise, Parliament, newspaper's direction; overview of organization and administration of the Chronicle.

2965 "Developing the Press in Developing Tonga," Tonga Chronicle,

March 15, 1973, p. 3.

Article reviews Tonga's Development Plan 1970-75 and the low priority given to development of information services, such as radio and newspaper and stresses the key role of information services in development.

2966 "The Tonga Chronicle, 1970-72." Working paper prepared at East-West Communication Institute, Honolulu, 1973.76 pp.

McClelland describes his two years as editor of the Tonga Chronicle; covers staff and administration; distribution; relations with the government and royal family; innovations.

2967 “Tonga Papers Enter 10th Year," PICN, 4, no. 1 (August 1973): 16.

Anniversary statement by editor of Tonga papers on the role and future of newspapers in Tonga.

2968 Barney, Ralph D. "An Early Public War of Words in Pacific Politics: Tonga, 1860-1890,' Journal of the Polynesian Society, 83, no. 3 (1974): 349-60.

Describes attempts to establish newspapers in Tonga from 1860 to 1890 . Papers reviewed include Fetu'u'o Tonga (Star of Tonga), Ko e Boobooi (Tonga Times); article reviewed in PICN, 5, no. 2 (June 1975): 5.

2969 “Fonua Reviews Papers' Progress," PICN, 4, no. 3 (May 1974): 2.

Interview with editor of Tonga Chronicle; emphasizes public participation in his paper, editorial policy, and circulation.

2970 "Siosiua Fonua Appointed Editor," PICN, 4, no. 3 (May 1974): 2.

Brief background on new editor of Tonga Chronicle. 
2971 “Editorial Adviser for Chronicle," Tonga Chronicle, July 18, 1974, 10: 4.

Chronicle staff joined by Neville Peat, New Zealand Volunteer Service Association volunteer.

2972 “'Tonga News," PICN, 5, no. 1 (February 1975): 11.

Personnel changes on Tonga Chronicle.

2973 McClelland, Robert. "What Sort of Newspaper for Tonga?” Tonga Chronicle, March 29, 1975, p. 5.

Stresses function of newspaper in Tongan society and how the paper must rely on the goals of the society in guiding its development. As a weekly publication, newspaper must stress national development information rather than current news. Problems are the lack of training for newspaper staff and downgrading of the journalism profession relative to government positions.

\section{RADIO BROADCASTING}

2974 “"News and Notes from Tonga," PIM, 1, no. 10 (May 1931): 8.

Contains complaints about the caliber of official news broadcasts by government radio station; better news said to be available faster from outside Tonga.

2975 “Broadcasting Service for Tonga," PIM, 37, no. 12 (July 1957): 59.

Reports revival of interest in establishing a radio broadcasting station in Tonga.

2976 “Broadcasting Station for Tonga,” PIM, 28, no. 8 (March 1958): 131.

Reports decision of Tongan government to build a radio station by 1959.

2977 “'Work Starts Soon on Tonga Radio," PIM, 29, no. 1 (August 1958): 139.

Short note on construction of Tongan radio station.

2978 “'Broadcasts Soon,” PIM, 30, no. 10 (May 1960): 47-48.

Short article on soon-to-be completed broadcasting station.

2979 “A Gift for Tonga's Broadcast Station," PIM, 30, no. 11 (June 1960): 131.

Reports gift of transcription equipment and records.

2980 “Tonga Broadcasting Soon, Plus Radio Aids," PIM, 31, no. 2 (September 1960): 128.

Completion of Tonga broadcasting station near.

2981 “Tonga will Operate a Broadcasting Station Soon," PIM, 31, no. 7 (February 1961): 127.

Reports arrival of European personnel to operate Tonga broadcasting station, plans of government to import transistor radios to sell at low price.

2982 “Tonga is Now on the Air," PIM, 31, no. 8 (March 1961): 117.

Reports initiation of broadcasting by new station at Nuku'alofa.

2983 “'Tonga Radio Has 'Excellent' Cover,' PIM, 31, no. 9 (April 1961): 65.

Notes official opening of Tonga broadcasting station $\mathrm{ZCO}, \mathrm{Nuku}$ 'alofa, and describes programming and coverage.

2984 “'Power of Advertising Proved in Tonga," PIM, 31, no. 12 (July 1961): 134.

Short report on the results of advertising on Tongan radio.

2985 “A Big Day for Tonga,’ PIM, 32, no. 1 (August 1961): 61-63.

Article announces opening of station ZCO; staffed by Tongans and New Zealanders. 
2986 “'It's Like Licking Four Ice Creams at Once," PIM, 34, no. 1 (August 1963):

74.

Reports popularity of a Radio Station ZCO broadcaster, who speaks four languages.

2987 “'In a Nutshell,” PIM, 34, no. 3 (October 1963): 123.

Reports radio station being built on Niuafo'ou; original station destroyed in 1946 volcanic eruption.

2988 "Man Behind the Call of the Friendly Islands," PIM, 35, no. 2 (February 1964): 56.

Reviews career of R. Geoff Haggett, first manager of Tonga Broadcasting Commission.

2989 “Aid to Developing Countries,' Educational Television International, 1, no. 1 (March 1967): 50-54.

Lists British financial and personnel assistance to broadcasting and information services in other countries, 1964 to June 1966, with reference to Tonga.

2990 Wendt, Sue. “Less English for Fiji Radio-And No TV?'” PIM, 41, no. 3 (March 1970): 32.

Article on radio broadcasting in Fiji reports Radio Tonga the most listened-to external station in Fiji.

2991 “'Radio Tonga May Go Independent,” PICN, 4, no. 1 (August 1973): 16.

Brief note on possibility of independent status for Radio Tonga; new manager sought.

2992 “Tonga Manager Post Vacant After First Search,"' PICN, 4, no. 2 (December 1973): 12.

Describes difficulties of filling position of manager of Radio Tonga.

2993 “'Tonga's Broadcasting Head,” $A B U$, no. 102 (March 1974): 39.

'Uliti Palu, acting manager of the Tonga Broadcasting Commission, visited the Asian Broadcasting

Union's Sydney office; article reviews his career.

2994 "'Radio Foundation Member Retires," Tonga Chronicle, August 15, 1974, 3:

2.

Reviews career of 'Uliti Palu, a founder of Radio Tonga in 1961, who held many posts in news reporting and management.

2995 “BBC Man Joins Radio Tonga," Tonga Chronicle, September 5, 1974, 3: 1.

Reviews career of David Porter, new manager of Radio Tonga.

2996 “' 'Barney' Calls it a Day,” Tonga Chronicle, February 27, 1975, 3: 1.

Reviews career of Herbert Barnard, retiring from British Colonial Service; he was announcer of "Bits \& Pieces" program over radio station.

2997 “'Independence for TBC," $A B U$, no. 117 (July-August 1975): 19-20.

Tonga Broadcasting Commission became an independent statutory body on July 1, 1975. Previously TBC was a public service unit of Tongan government. Article reviews consequences of this change and some highlights of Tongan broadcasting. Article reviewed in Pacific Islands Communication Newsletter, 5, no. 4 (December 1975): 11.

2998 “New Broadcasting Manager for Tonga,” PICN, 6, no. 2 (June 1976): 1, 2.

Sione Tu'itavaka Fusimalohi named manager of the Tonga Broadcasting Commission 


\section{SATELLITE COMMUNICATION}

See also Pacific Islands General

2999 “Talking by Satellite," Tonga Chronicle, April 27, 1972, p. 12.

Article reviews inauguration of University of the South Pacific's satellite station.

3000 Blundell, Margaret. "PEACESAT and The Smaller Terminals: To Big Brother with Love.' Paper prepared for the Users of PEACESAT Conference, April 28-May 2, 1975, East-West Center, Communication Institute, Honolulu. 3 pp.

Tonga PEACESAT terminal manager reviews problems in network's programming, especially concerning small-island users. Author suggests late-evening conferences on topics of great interest to many listeners.

\section{TELEVISION}

3001 “'Samoa Prepares for Its (Educated) Goggle Box,"' PIM, 33, no. 2 (September 1962): 53-4.

Article about introduction of TV into American Samoa relates that government officials in Western Samoa and Tonga have had informal talks about TV reception for their islands.

3002 “NHK Considering Television Aid in Tonga," PICN, 4, no. 3 (May 1974): 11.

Outlines proposed communications development in Tonga, including Japanese offer to introduce television.

3003 "TV Station for Western Samoa? KVZK-TV Offer," PICN, 6, no. 2 (June 1976): 1 .

Reviews exploratory discussions concerning gift of unused TV station in American Samoa to Western Samoa. KVZK considering similar offer to Tonga. 


\title{
Trust Territory of the Pacific Islands (Micronesia)
}

\author{
INDEXES, GUIDES, REFERENCE WORKS
}

3004 Index to the Micronesian Reporter. Saipan: Education Department, Trust Territory of the Pacific Islands, $1974.85 \mathrm{pp}$.

Indexes Micronesian Reporter from March 1956 to third quarter, 1974, and the predecessor Micronesian Monthly, November 1951 to March 1956.

3005 Namposhi Kenkyūkai. Union Catalogue of Books and Periodicals on Southeast Asia Written in European Languages Kept in the Major Institutions in Japan: Humanities and Social Sciences. Tokyo: Society of South Asian Studies, $1955.336 \mathrm{pp}$.

3006 United States. Navy Department. Administrative Organization and Personnel of the Japanese Mandated Islands. Washington, 1944. $26 \mathrm{pp}$.

3007 Civil Affairs Handbook: Mandated Mariana Islands. OPNAV 5OE-8. Washington, 1944. $205 \mathrm{pp}$.

3008 Civil Affairs Handbook: Marshall Islands Statistical Supplement.

Washington, 1944. $38 \mathrm{pp}$.

Communication data on page 20.

3009 Handbook on the Trust Territory of the Pacific Islands: A Handbook for Use in Training and Administration. Washington, 1948. $305 \mathrm{pp}$.

A survey of the history and conditions of Micronesia for military administrators; contains brief information on communication, especially radio. P22-1. Washington: Government Printing Office, 1946. 113 pp.

Prepared for guidance of U.S. military government officers in 1943; communication facilities information on pages 83-84. 
3011 United States. Trust Territory of the Pacific Islands. Public Information Office Library. Recent Acquisitions. Monthly since January 1967.

3012 United States. Trust Territory of the Pacific Islands. Truk District Handbook of Information. $1967.85 \mathrm{pp}$.

Includes short section on radio facilities, including station WSZC.

3013 Yap District Handbook of Information. 1970. 55 pp.

Includes section on communications department; reviews radio station development.

\section{NEWSPAPERS, PERIODICALS}

3014 ACTION BULLETIN. See Micronesian Independence Support Committee. Bulletin.

3015 BUCKETS. Koror, Palau District, Caroline Islands. March 10, 1952—? Weekly.

3016 CAROLINES OBSERVER. Colonia, Yap Islands. December 1976-. Biweekly in English and Yapese.

3017 DIDIL A CHAIS. Koror, Palau District, Caroline Islands. April 1968January? 1972. Frequency varied, in English and Palauan. Published by Palau Community Action Agency.

3018 ENNANE. Majuro, Marshall Islands. 1976. Weekly in Marshallese, published by Micronitor News and Publishing Company.

3019 ESG NOTES. Saipan, Mariana Islands. 1975?- . Biweekly, published by Department of Public Affairs, Trust Territory.

A summary of news and events related to the Trust Territory's Education for Self-Government program.

3020 FREE PRESS. Saipan, Mariana Islands. November? 1974—. Irregular.

3021 FRIENDS OF MICRONESIA. Berkeley, California. 1971-Fall 1974. Frequency varied, then quarterly.

3022 HEADS AND HANDS. Majuro, Marshall Islands. October 1949-1951? Monthly; in Marshallese and English; published by Department of Education. Earlier paper, Shipwreck (?-August 1949?), published by Civil Administration Unit.

3023 HIGHLIGHTS. Saipan, Mariana Islands. 1966-. Biweekly in English; published by U.S. Trust Territory government.

3024 I GASETA. Saipan, Mariana Islands. March 1974-75? Weekly in Chamorro and English.

3025 LOAN EBEYE RANKIN. Ebeye, Marshall Islands. -197?- Frequency not determined. In Marshallese.

3026 LOAN RAN KEIN. Majuro, Marshall Islands. 1953?-54? Frequency not determined. In Marshallese. Published by the Education Department. 
3027 MAJURO TIMES. Majuro, Marshall Islands. December 1952?-56? Frequency varied, generally biweekly.

3028 MARIANAS BULLETIN. Saipan, Mariana Islands. January 1967-May 1968. Weekly publication by the District Administration. Previously titled: Marianas Panorama (1965-January 1967).

3029 MARIANAS PANORAMA. See Marianas Bulletin.

3030 MARIANAS VARIETY \& NEWS AND VIEWS. Saipan, Mariana Islands. March 16, 1972 - Weekly in English. Predecessor was Micronesia Star (February 20, 1971-February 19, 1972), a weekly.

3031 MARSHALL ISLANDS JOURNAL. Majuro, Marshall Islands. December 14, 1965-January 1969. Weekly in English and some Marshallese.

3032 MARSHALL ISLANDS JOURNAL, n.s. Majuro, Marshall Islands. October 1976 - First triweekly, then semiweekly in Marshallese; published by Micronitor News and Publishing Company.

3033 MARSHALL ISLANDS OBSERVER. Majuro, Marshall Islands. December 12, 1960-63? Weekly published by the Education Department.

3034 MET PORAUS. Moen, Truk District, Caroline Islands. 1967-197? Weekly in Trukese and English. Previous paper titled: Truk Tide (1952-September 29, 1967), published biweekly in English with some articles in Trukese.

3035 MICRO SCOPE. Saipan, Mariana Islands. 1968?-69?

3036 MICRONESIA STAR. See Marianas Variety \& News and Views.

3037 MICRONESIA TIMES. Chalan Kanoa, Saipan, Mariana Islands. May 6, 1965 — ? Weekly. Titled also: Micronesian Times.

3038 MICRONESIAN FREE PRESS. Tinian, Mariana Islands. January 1969-? Monthly.

3039 MICRONESIAN INDEPENDENCE SUPPORT COMMITTEE. BULLETIN. Honolulu, Hawaii. November 10, 1975-. Monthly. Title varies to: Action Bulletin.

3040 MICRONESIAN INDEPENDENT. Majuro, Marshall Islands. December 1974- Weekly in Marshallese and English. Previously titled Micronitor (February 1970-December 1973), published weekly.

3041 MICRONESIAN MONTHLY. See Micronesian Reporter.

3042 MICRONESIAN NEWS SERVICE. Saipan, Mariana Islands. 1968?-? At head of title: $M N S$. News releases concerning Micronesia.

3043 MICRONESIAN REPORTER. Saipan, Mariana Islands. November 1951 - Frequency varied; now published quarterly in English by the U.S. Trust Territory of the Pacific Islands Government. Previously titled: Micronesian Monthby (1951-56). 
3044 MICRONESIAN STAR. See Marianas Variety \& News and Views.

3045 MICRONESIAN TIMES. See Micronesia Times.

3046 MICRONITOR. See Micronesian Independent.

3047 MNS. See Micronesian News Service.

3048 MOGETHIN. Yap, Western Caroline Islands. January 26-July 31, 1968. Frequency varied. In English and Yapese. Published by Good News Press.

3049 NANYŌ MAINICHI SHIMBUN. Saipan, Mariana Islands. January? 1942June 11, 1944. Daily in Japanese. Microfilmed issues of March 28 to June 11, 1944, available at Library of Congress.

3050 NANYŌ SHIMPO. Palau, Caroline Islands. 1943?-44? Daily? in Japanese. Library of Congress has microfilmed issues of December 4, 1943-July 9, 1944.

3051 OUTRIGGER. Agana, Guam. 1969?-70? Publication varied. Produced by Micronesian students at the University of Guam.

3052 PALAU NEWS. Koror, Palau District, Caroline Islands. 1952?-? Frequency not determined. In Palauan.

3053 PALAU POST. Koror, Palau District, Caroline Islands. 1962?-? Frequency not determined.

3054 PONAPE-PER. Ponape, Caroline Islands. 1958?-February 1967. Weekly in English. Published by the District Administration, Ponape, Caroline Islands.

3055 RAI REVIEW. Yap, Western Caroline Islands. 1963?-February 1968. A weekly in Yapese and English published by the District Administration, Yap, Western Caroline Islands.

3056 SENYAVIN TIMES. Ponape, Eastern Caroline Islands. February 1967-72. Biweekly in English and Ponapean. Published by Ponape Community Action Agency.

3057 SHIPWRECK. See Heads and Hands.

3058 SIMPUNGUN CHUUK. Moen Island, Truk District, Eastern Caroline Islands. April? 1950-5? Weekly in Trukese.

3059 TAMILANG. Yap, Western Caroline Islands. 1960-6? Frequency not determined. In Yapese and English.

3060 TIA BELAU. Koror, Palau District, Western Caroline Islands; then Guam, then Palau. June 28, 1972-75? Frequency varied, last published as a monthly. In Palauan and English.

3061 TRUK REVIEW. Truk, Caroline Islands. 1957-6? Monthly in Trukese and English.

3062 TRUK TIDE. See Met Poraus.

3063 YOUNG MICRONESIAN. Honolulu. January 1971-December 1972? Publication varied, usually monthly. Published by Micronesian students in Hawaii. 


\section{GOVERNMENT AND INTERNATIONAL AGENCY REPORTS}

3064 Hall, Edward T., and Karl J. Pelzer. The Economy of the Truk Islands: An Anthropological and Economic Survey. Honolulu: U.S. Commercial Company, 1946. $116 \mathrm{pp}$.

Recommendations include one for establishing a vernacular newspaper for Truk.

3065 Japan. South Seas Bureau. Annual Report to the League of Nations on the Administration of the South Sea Islands Under Japanese Mandate. Tokyo, 1921-1938.

3066 Oliver, Douglas L. Planning Micronesia's Future: A Summary of the United States Commercial Company's Economic Survey of Micronesia. 1946. Cambridge: Harvard University Press, 1951. 94 pp. Rpt., Honolulu: University of Hawaii Press, 1971.

Discussion of communication needs on pages $81-83$.

3067 United States. Department of State. Annual Report to the United Nations on the Administration of the Trust Territory of the Pacific Islands. Washington, 1948 -.

Prepared by the Navy Department until 1952.

3068 United States. High Commissioner. Annual Report of the High Commissioner of the Trust Territory of the Pacific Islands to the Secretary of the Interior. Washington, 1952 -

3069 United States Commercial Company. Economic Survey of Micronesia, 16 vols. Honolulu: United States Commercial Company, 1946.

Report prepared for the U.S. Navy by the U.S. Commercial Company, a subsidiary of the Reconstruction Finance Corporation. General social and demographic information; brief mention of communication capacities and personnel.

\section{CINEMA}

3070 Takeuchi, Floyd. "Jen etal in mubi (Let's go to the movies)," PICN, 6, no. 1 (March 1976): 9.

Describes thriving movie-going activities in Majuro, Marshall Islands, based on statistics gathered by writer.

\section{COMMUNICATION RESEARCH}

3071 Hitchcock, David I., Jr. "Information and Education for Self-Government in Micronesia." U.S. Department of State, Foreign Service Institute, Senior Seminar in Foreign Policy, 16th Session, 1973-74. 43 pp.

Focuses on the role of mass media in developing political consciousness; includes portions of more than 100 interviews conducted in Micronesia, the United States, and Japan. Study reviewed in two parts in PICN, 4, no. 4 (September 1974): 11-12; 5, no. 1 (February 1975): 7-8.

3072 Smith, Dan. "Television in the Marianas," Micronesian Reporter, 22, no. 1 (1974): 8-12.

Reports the findings of a study of the effects of four years of television on the people of Saipan, Marianas Islands; deals with the amount of time spent viewing television, number of families with television sets, how television is judged as a source of information, and effects of television on attitudes. 
3073 Carney, Sandra. "Airways of Micronesia: A Study of Radio Broadcasting in the U.S. Trust Territory of the Pacific Islands." Available at East-West Center, Communication Institute. May 1974. 19 pp.

A study of the social impact of radio broadcasting on select Micronesia cultures.

3074 "Study to Examine TV's Effects on Micronesian Children," PICN, 5, no. 1 (February 1975): 6.

Article, based on the 1973-74 annual report of the Markle Foundation, describes the study of influence of television on children in three developing areas, including children in Micronesia.

\section{EDUCATION AND TRAINING OF COMMUNICATORS}

3075 "Radio, TV News Training Discussed on PEACESAT," PICN, 4, no. 2 (December 1973): 5-6.

Deals with satellite training discussions with participants from Micronesia, New Zealand, Fiji, and Hawaii.

3076 “Radio Workshops," PICN, 4, no. 2 (December 1973): 11.

Brief article on training materials, objectives for radio production workshops held in Micronesia under the auspices of the Catholic Radio Production Center.

3077 University of Guam. Language Arts Division. "A Proposal for Interdisciplinary Study of Communication." Submitted to the Gannett Foundation July $15,1974.32 \mathrm{pp}$.

Discusses journalism training needs in Guam and Micronesia with detailed proposal for a journalism program at the University of Guam.

3078 Takeuchi, Floyd. "TT Journalism Training Scarce," PICN, 6, no. 2 (June 1976): 3, 6 .

Article reviews comments of Steve Woodworth and Elias Thomas of Saipan concerning low priority of journalism training in the Trust Territory administration and offers suggestions to improve training.

\section{EDUCATIONAL MEDIA}

3079 Platt, William J., and Philip H. Sorensen. Final Report: Planning for Education and Manpower in Micronesia. Menlo Park, California: Stanford Research Institute, $1967.212 \mathrm{pp}$.

Contains considerable detail on Micronesian manpower and education structure. Chapter on "Adult and Continuing Education" contains short review of public information services.

3080 Summary Report: Planning for Education and Manpower in Micronesia. Menlo Park, California: Stanford Research Institute, 1967. 26 pp.

3081 Scripts of Education for Self-Government Radio Broadcasts. Trust Territory of Pacific Islands, Task Force on Education for Self-Government. Published by Headquarters, Department of Public Affairs, Saipan. February 1974. 25 pp.

3082 Engle, Murry. "Paper Bridges for Far-Flung Islands," $S$ - $B$, March 26, 1975, F-1: 1 .

Reports on English-language teaching program in Micronesia which utilizes cut-out newspaper photos and other materials that students organize into their own newspaper. 


\section{FREEDOM OF THE PRESS/BROADCASTING}

3083 "Territory Now Open to Newsmen," Micronesian Monthly, 1, no. 2 (December 1951): 2.

Press release, December 5, 1951, says Territory no longer closed to the press; change-over in staff and shortages of transportation and quarters cited as reasons for former ban.

3084 Uherbelau, Victorio. "Micronesia Lacks an Independent Press," PIM, 40, no. 7 (July 1969): 42-43, 45.

Discusses the need for a free press in Micronesia uncontrolled by the U.S. Trust Territory administration; includes information on newspapers publishing in Micronesia; discusses problems that have retarded development of a free press.

3085 Uludong, F. T. "Micronesia Has Freedom of the Press Case," $A D V$, January 21, 1972, A-19: 1 .

Reviews case of Michael Malone, editor of Micronesia Star, published in Saipan. Notes taken by Malone while interviewing seamen charged with a crime at sea ordered turned in to the government.

3086 “Micronesian Press Freedom," PICN, 5, no. 3 (September 1975): 4.

Reviews Marshall Islands delegate Carl Heine's statements on press freedom in the recent Micronesian Constitutional Convention on Saipan; review of Marianas Variety columnist's statements on a friend's draft of the Constitution, done in a humorous manner; and a review of an editorial from the July 4 , 1975, Marianas Variety.

3087 Takeuchi, Floyd. "Prospects for a Free Private Press in Micronesia: Cautious Optimism," PICN, 6, no. 1 (March 1976): 1, 5, 6.

Discusses changes in press systems in Micronesia due to the first Micronesian Constitution, proposed November 1975; various professionals give their opinions.

\section{GOVERNMENT INFORMATION ACTIVITIES}

3088 "Basilius Named Information Chief," PICN, 4, no. 4 (September 1974): 13.

Reports appointment of Bonifacia Basilius to the directorship of the Trust Territory Public Information Division.

3089 “New MNS Chief Named; Anderson joins 'Voice'," PICN, 5, no. 1 (February 1975): 6.

Francisco S. Rosario of Saipan named bureau chief of Micronesian News Service, replacing Jon Anderson, who joined Voice of America in Washington, D.C.

3090 "The Press and Bureaucracy-Editorial from the Marianas Variety," PICN, 5, no. 1 (February 1975): 9.

Editorial criticizes director of Trust Territory Health Services for avoiding questions posed by Variety reporters; lists other examples of noncooperation by officials.

3091 "TT Administration Holds Weekly Press Conference," PICN, 5, no. 4 (December 1975): 12.

Trust Territory government has instituted formal press conferences, apparently in response to criticism from the local press.

\section{NEWS AGENCIES}

3092 “New MNS Chief Named; Anderson Joins 'Voice'," PICN, 5, no. 1 (February 1975): 6.

Announces appointment of Francisco S. Rosario as head of Micronesian News Service, replacing Jon A. Anderson. 


\section{THE PRESS}

\section{General}

3093 Kulz, H. “Die Presse in den deutschen Kolonien," Koloniale Monatsblatter, June 1914.

3094 Lange, Fritz. "Zur Geschichte des Pressenwessens in den deutschen Kolonien," Zeitungswissenschaft, 6 (1929).

3095 Embree, John F. "Military Government in Saipan and Tinian," Applied Anthropology (Human Organization), 5, no. 1 (Winter 1946): 1-39.

Contains brief reference to locally produced newspapers under military government.

3096 Richard, Dorothy E. United States Naval Administration of the Trust Territory of the Pacific Islands, 3 vols. Washington: Office of the Chief of Naval Operations, U.S. Navy Department, 1957. 767, 573, 1340 pp.

Volume three contains brief references to mimeographed weekly papers published by the civil administration.

3097 Kahn, E. J., Jr. “A Reporter at Large: Micronesia,” New Yorker, 42, no. 16 (June 11, 1966), pp. 42 ff.; no. 17 (June 18, 1966), pp. 42 ff.; no. 18 (June 25, 1966), pp. $56 \mathrm{ff}$.

Includes account of journalism in Trust Territory and Guam in mid-1960s.

3098 A Reporter in Micronesia. New York: W. W. Norton and Co., 1966. $313 \mathrm{pp}$.

Journalistic account of conditions in the U.S. Trust Territory of the Pacific Islands and Guam in the mid-1960s; includes description of the state of publishing, enumerating periodicals and occasionally referring to editorial positions.

3099 Yim, Evelyn. “The Press in Micronesia." Undergraduate research paper. May 15, 1968. Copy in Pacific Collection, Hamilton Library, University of Hawaii. 18 pp.

Describes Micronesian social conditions and position of newspapers in major island groups. Reviews eight major periodicals in Trust Territory and the idea for a "United Micronesian Press" to consolidate islands newspapers into a regional press.

3100 Quigg, Philip W. "Coming of Age in Micronesia," Foreign Affairs, 47, no. 3 (April 1969): 493-508.

Includes a brief sketch of the press in Micronesia.

3101 "Guam Papers Seek Marianas Business," Pacific Daily News, March 31, 1973 , p. 25.

Reports application by Guam Publications, publisher of Guam's two daily newspapers, to do business in the Trust Territory and eventually to print a Marianas edition of one of the Guam newspapers.

3102 “Micronesia Roundup,” PICN, 4, no. 3 (May 1974): 10.

Reviews status of communication media in the U.S. Trust Territory of the Pacific Islands.

3103 Hitchcock, David I. “Micronesian Media: A 1974 View," PICN, 4, no. 4 (September 1974): 11-12.

Reviews the history and use of radio and television in Micronesia in relationship to the issue of "Education for Self-Government." (Part 1 of two-part series.) 
3104 "Micronesian Media: Part II-Newspapers," PICN, 5, no. 1

(February 1975): 7-8.

Condensed from a study by David Hitchcock, article reviews four newspapers in Micronesia; covers circulation figures, types of coverage, competition from papers flown into region from elsewhere. Papers studied are: Marianas Variety \& News and Views, I Gaseta, Tia Belau, and the Micronesian Independent.

\section{Buckets}

3105 “New Koror Newssheet," Micronesian Monthly, 1, no. 5 (March 1952): 26.

Notes appearance of first issue of The Buckets, published weekly at Koror, Palau.

\section{Free Press}

3106 "Changes with Islands Press," PIM, 45, no. 11 (November 1974): 10.

Notes changes at Free Press, Saipan.

\section{Gaseta}

3107 “New Weekly, I Gaseta, Appears," PICN, 4, no.1 (August 1973): 11.

Notes appearance of new Saipan paper, edited by Victor Pangelinan.

\section{Majuro Times}

3108 “Majuro Times Revived," Micronesian Monthly, 4, no. 1 (January-February 1956): 16.

Notes renewed publication of Majuro Times in Marshall Islands.

\section{Marianas Variety \& News And Views}

3109 "Variety Changes Due," PICN, 4, no. 2 (December 1973): 11.

Brief article on editorial policy, staff of Marianas Variety, Saipan.

3110 Pangelinan, Vic. Untitled paper prepared for South Pacific Editors' Conference, Suva, Fiji, July 30-August 5, 1972. Honolulu: East-West Center, Communication Institute. 3 pp.

Discusses news distribution in U.S. Trust Territory of the Pacific Islands and status of governmentcontrolled news media versus private newspapers, with particular reference to Marianas Variety.

3111 “Anderson Reflects on Press Development," PICN, 4, no. 3 (May 1974): 10.

Reprints views of Marianas Variety columnist after one year of contributing columns to the paper.

3112 "Variety Strengthens Coverage, Improves Format," PICN, 5, no. 2 (June 1975): 8.

Column by Marianas Variety writer discusses format changes at the paper and increased journalistic responsibilities.

\section{Met Poraus}

3113 “'Newspaper Merger Planned,’ PICN, 2, no. 2 (August 1971): 13.

Brief notice of proposed merger of Met Poraus, Truk, and Micronitor, Marshall Islands.

\section{Micronesian Daily News}

3114 “Marshallese Edition Published," PICN, 5, no. 1 (February 1975): 6.

Announces publication of Ennane, a newspaper in Marshallese, by Micronitor News and Printing. 


\section{Micronesian Independent}

3115 “Newspaper Merger Planned," PICN, 2, no. 2 (August 1971): 13.

Brief notice of proposed merger of Met Poraus, Truk, and Micronitor, Marshall Islands.

3116 “Independent Promises Micronesia-Wide Coverage," PICN, 4, no. 3 (May 1974): 10.

Details of name change, editorial policy, staff of Micronesian Independent, formerly Micronitor.

\section{Micronesian Reporter}

3117 “Index Published for Micronesian Reporter," PICN, 5, no. 4 (December 1975): 6.

Index to Micronesian Reporter issued by Trust Territory government; includes predecessor, Micronesian Monthly.

\section{Pacific Daily News/Pacific Dateline}

(The defunct Pacific Dateline had a special Saipan edition)

3118 "Guam Paper, Micronesia Congress in News Agreement," PICN, 4, no. 1 (August 1973): 5-6.

Gives details of news agreement between Congress of Micronesia and the Guam newspapers, Pacific Daily News and Pacific Dateline, and background on disagreement.

3119 “Newspaper Competition in Saipan," PICN, 4, no. 1 (August 1973): 12.

Discusses unsuccessful efforts of Guam Publications, Inc., to obtain permission to do business in Saipan.

3120 "Saipan-Guam Situation," PICN, 4, no. 2 (December 1973): 10.

Commentary on efforts of Guam's Pacific Daily News to expand operations to Saipan, Mariana Islands.

\section{Ponape-Per \\ Senyavin Times}

3121 “Publication of Ponape-Per," PIM, 38, no. 4 (April 1967): 27.

Announces Ponape-Per, oldest continuing publication in the Trust Territory, stopped on February 17 when Senyavin Times started.

\section{Tia Belau}

3122 “' 'Pressure' Cited in Closure of Palau Paper," PICN, 4, no. 1 (August 1973): 11.

Gives background of closure of the biweekly Tia Belau on Palau and move to Guam.

3123 "Tia Belau Seeks Financial Assistance," PICN, 5, no. 4 (December 1975): 12.

Paper was not published for six months while waiting for new printing press; lack of other equipment and financial problems have hampered operations. 


\section{Young Micronesian}

3124 “" 'Young Micronesian' Magazine Hits Report," S-B, April 10, 1971, A-8: 2.

Magazine published by local Micronesian students printed parts of a 1963 American government report, known as the Solomon Report, after its author's name, reviewing annexation and development plans that author says are "to colonize and annex Micronesia."

\section{PRESS/BROADCASTING ORGANIZATIONS}

3125 “Press Club Considered," PICN, 4, no. 4 (September 1974): 13.

Reports efforts to form press club or possibly a news association at Saipan, Mariana Islands.

\section{PRINTING}

3126 Alden, John E. "A Press in Paradise: The Beginnings of Printing in Micronesia," Papers of the Bibliographical Society of America, 38, no. 3 (1944): 269-83.

History of the establishment of the first printing press in Micronesia, at Ponape in the Caroline Islands, by missionaries of the American Board of Commissioners for Foreign Missions in 1856; includes list of publications printed at Ponape, 1856-1859.

\section{RADIO BROADCASTING}

\section{7 “Davis Confers on Guam," NYT, August 14, 1944, 3: 5.}

Reports establishment of a shortwave radio station, WXLB, at Saipan, Mariana Islands, to serve U.S. military forces.

3128 "Radio WSZO Ushers in New Era in Marshalls," Micronesian Monthly, 2, no. 10 (October 1953): 20.

Reprint of article from Majuro Times on the commissioning of the first Trust Territory government radio station.

3129 “Micronesia to Have Commercial Radio," PIM, 24, no. 8 (March 1954): 87.

Reports authorization of construction of a commercial radio broadcasting station to supplant the existing armed forces station.

3130 "The Voice of the Marshall Islands," Micronesian Reporter, 4, no. 2 (1956): 18.

Describes Marshallese-language programming of WSZO.

3131 "Broadcasting in the Pacific," SPB, 6, no. 4 (October 1956): 41-45, 56.

Describes broadcasting facilities in the U.S. Trust Territory of the Pacific Islands and other Pacific areas.

3132 Richard, Dorothy E. United States Naval Administration of the Trust Territory of the Pacific Islands, 3 vols. Washington: Office of the Chief of Naval Operations, U.S. Navy Department, 1957. 767, 573, 1340 pp.

Volume three contains brief reference to a short-lived Armed Forces Radio Service station on Truk.

3133 “'Station WSZO Broadcasting,"' Micronesian Reporter, 7, no. 3 (1959): 6-8.

Short history of WSZO; information on staff and audience and effects on local population.

3134 "First Commercial Radio Station on the Air," Micronesian Reporter, 10, no. 2(1962): 20.

KVZA, Moen Island, Truk District, licensed to broadcast. 
3135 “'Radio Coming Up," Micronesian Reporter, 11, no. 1 (1963): 20.

Reports resumption of broadcasting by WSZO after extended period during which a new station was built; notes plans for other stations.

3136 "Grant-in-Aid Authorized for Ponape Broadcast Station," Micronesian Reporter, 11, no. 3 (1963): 8.

Reports grant made to Ponape District Legislature for construction of a radio station.

3137 "Headquarters Broadcast Center Begins Operation," Micronesian Reporter, 11 , no. 4 (1963): 6.

Describes operation of central depository and reproduction unit for radio broadcast tapes.

3138 “" 'The Voice of Yap' Completes TT's Broadcast Network," Micronesian Reporter, 13, no. 1 (1965): 8.

Reports the opening of station WSZA.

3139 LaForrest, James R. "To Keep the Public Informed," Micronesian Reporter, 14, no. 1 (1966): 14.

Short summary of growth of station WSZO.

3140 "Trust Territory Radio Stations Locally Designed," $S B A$, January 5, 1969, E-2: 5 .

Construction of two Trust Territory radio stations on Saipan and Majuro will begin early in year; scheduled for completion April 1969.

3141 Quigg, Philip W. "Coming of Age in Micronesia," Foreign Affairs, 47, no. 3 (April 1969): 493-508.

Includes a brief sketch of the press and broadcasting in Micronesia.

3142 Satō, Katsuzō. "Parao hōsōkyoku shi" [A history of the Palau radio station], NHK bunken nempo [Annual bulletin of NHK radio and television culture research], (1971): 255-70.

A historical account of Japanese broadcasting activities in Micronesia, centering on the activities of NHK station JRAK, Koror, Palau, established in 1941; contains data on radio usage in Micronesia in the 1930s and 1940s; an English abstract of the article appears in Hidetoshi Kato, ed., Japanese Research on Mass Communication: Selected Abstracts (Honolulu: University Press of Hawaii, 1974), p. 110.

3143 Nippon hōsō kyōkai. Sōgō hōsō bunka kenkyūjo. Hōsō shi henshū shitsu [NHK Radio and Television Culture Research Institute, Broadcasting History Compilation Office]. Parao hōsōkyoku [The Palau broadcasting station]. Hōsō shiryō shū 5 [Broadcasting historical records collection no. 5]. Tokyo: Nippon hōsō kyōkai, n.d. 506 pp.

Contains a history of the Japanese broadcasting station at Palau, 1941-1944, and a collection of historical materials related to the station, including official documents, excerpts from diaries and memoirs, newspaper and periodical articles, and statistical material on the station's facilities, operations, and staff; with photos and maps.

3144 “'Radio Majuro Report,"' PICN, 2, no. 2 (August 1971): 8.

Describes WSZO, Majuro, Marshall Islands, its staff, and programming.

3145 “TT Broadcasting," PICN, 2, no. 2 (August 1971): 19-20.

A report on Trust Territory radio broadcasting, staff, training, expansion. 
3146 Donchin, Gwyneth. "Broadcasting at the Birth of a New State-Micronesia." Paper presented to the International Symposium on Broadcasting in the Pacific Nations, San Francisco, April 21-22, 1972.

3147 Callison, George T. "Broadcasting in the Trust Territory of the Pacific Islands," $A B U$, no. 82 (March 1972): 9-12.

Describes operations, programming, staff training, and plans of the broadcasting stations operated by the Trust Territory government.

3148 “Commercial Radio Application," PICN, 4, no. 1 (August 1973): 13.

Reports application by Micronesian Broadcasting Corporation for permit to build a private radio station at Saipan, Mariana Islands.

3149 “New Name for TT Broadcasting," PICN, 4, no. 1 (August 1973): 13.

Notes adoption of name Micronesian Broadcasting Service.

3150 “'Broadcast Chief Named,"' PICN, 4, no. 2 (December 1973): 10.

Reports appointment of Elias H. Thomas as chief of Broadcast Division of the U.S. Trust Territory of the Pacific Islands.

3151 "MBS Radio-The Bridge Which Links 100 Islands," $A B U$, no. 104 (May 1974): 19.

Reviews Micronesian Broadcasting Service.

3152 “Micronesia Roundup,” PICN, 4, no. 3 (May 1974): 10.

Reviews status of mass media in the U.S. Trust Territory of the Pacific Islands.

3153 Smith, Dan. “Marshall Island's Radio Boosts Power," PICN, 6, no. 2 (June 1976): 4.

Power increase to $10 \mathrm{kw}$ allows listeners in outer islands to listen to WSZO on pocket radios rather than radios with external antennas.

3154 Thomas, Elias. “Marianas Broadcasting Fate Uncertain," $P I C N, 6$, no. 2 (June 1976): 10, 12.

Reviews uncertain status of radio station KJQR, owned by the Trust Territory of the Pacific Islands, as a result of separation of the Northern Marianas from the rest of the Trust Territory of the Pacific Islands.

\section{SATELLITE COMMUNICATION}

See also Pacific Islands General

3155 “Saipan Joins University's Pan-Pacific Radio Network," $A D V$, April 18, 1973: F-12.

Reviews entry of Saipan into PEACESAT system.

3156 “Micronesia Becomes Affiliated with PEACESAT," Highlights, May 1, 1973, pp. 1-2.

Satellite station at Saipan begins operation. Article reviewed in PICN, 4, no. 1 (August 1973): 11.

3157 “Radio, TV News Training Discussed on PEACESAT," PICN, 4, no. 2 (December 1973): 5, 6.

Three teleconferences over PEACESAT discussed training for radio and television news personnel, with participants from New Zealand, Micronesia, Fiji, and Hawaii. 
3158 "PEACESAT Exchanges Pacific Area News," Pacific Daily News, June 28, 1974, 26: 4.

Reviews satellite-based Pacific News Exchange, which Saipan has joined.

3159 "PEACESAT Programs Start on Saipan Monday," Pacific Daily News, July 20, 1974, 21: 1 .

Reviews satellite program.

3160 Callison, George T. "PEACESAT: Communication by Satellite for Micronesia." Micronesian Reporter, 22, no. 4 (1974): 38-42.

Review of PEACESAT projects at Micronesian terminals.

3161 Takeuchi, Floyd. "Micronesians Set PEACESAT First," PICN, 5, no. 4 (December 1975): 3.

Students from Pacific Islands attending Hawaii institutions of higher education questioned their elected representatives in Saipan via PEACESAT satellite conference.

\section{TELEVISION}

3162 “Micronesia Roundup," PICN, 4, no. 3 (May 1974): 10.

Reviews status of mass media in the U.S. Trust Territory of the Pacific Islands.

3163 Smith, Dan. "Television in the Marianas," Micronesian Reporter, 22, no. 1 (1974): 8-12.

Reports findings of a study of the effects of four years of television on the people of Saipan; discusses viewing habits, attitudes toward television, effects of television on attitudes.

3164 “Palau to Get Cable TV," PICN, 5, no. 2 (June 1975): 8.

Micronesian National Communication Network, Ltd., owned by five Palauans, will operate a cable television system on Palau; first broadcast expected October 1975.

3165 “New Saipan TV Studio," PICN, 5, no. 3 (September 1975): 4.

WSZE, Saipan's only television station, expected to send a stronger signal from its new facilities.

3166 “'Saipan TV Woes Never Seem to End," PICN, 5, no. 4 (December 1975): 8.

Marianas Variety reports the only TV station in Saipan has problems with poor signal. 


\section{Tuvalu}

(The Ellice Islands separated from the Gilbert Islands in October 1975 and became Tuvalu. Full separation occurred in January 1976. Information concerning both island groups is listed under each name.)

\section{NEWSPAPERS, PERIODICALS}

3167 ATOLL PIONEER. Tarawa. September 7, 1972—. Weekly in English and Gilbertese. Published by Information Division, Gilbert Islands. Incorporated Tero (Gilbert Islands paper) in May 1974; incorporated Valo (September 16, 1965-May 1974), a biweekly in Ellice and English, in May until September 1974, when the Tuvalu reporters transferred to Funafuti. Superseded Colony Information Notes (1963-1972), weekly in English; News from The Gilbert and Ellice Islands Colony (1955-1962), monthly in English. Frequency varied in early years.

3168 BANAN TUNGAVALU. JOURNAL OF THE TUNGAVALU SOCIETY. Tarawa. 1974 - Monthly in Gilbertese and English.

Contains general news.

3169 COLONY INFORMATION NOTES. See Atoll Pioneer.

3170 GILBERT AND ELLICE ISLANDS COLONY GAZETTE. Tarawa. 1968-1975. Official gazette; published monthly with legal supplements. Previous legal gazette was Western Pacific High Commission Gazette (1914-1967) which included ordinances, administrative changes, etc., for the Gilbert and Ellice Islands, Fiji, British Solomon Islands, and New Hebrides, while each island group was part of Great Britain's Pacific Colonies.

3171 NEWS FROM THE GILBERT AND ELLICE ISLANDS COLONY. See Atoll Pioneer.

3172 TALA O TUVALU. Tarawa. 1945-1964. Monthly in Ellice. Published by Gilbert and Ellice Islands Information Department.

3173 TERO. See Atoll Pioneer.

3174 TUVALU NEWS SHEET. Funafuti. January 1976? — . Biweekly in English and Ellice. Published by the Broadcasting Information Office. 
3175 VALO. See Atoll Pioneer.

3176 WESTERN PACIFIC HIGH COMMISSION GAZETTE. See Gilbert and Ellice Islands Colony Gazette.

\section{GOVERNMENT AND INTERNATIONAL AGENCY REPORTS}

3177 Kittermaster, A. M. "A Report on Information and Broadcasting Services in the Gilbert and Ellice Islands." London. Commissioned by the Ministry of Overseas Development. July 1970. 69 pp.

Report describes and assesses broadcasting services, departmental structure and staff, programming, information services, community development and communication services; role of information and broadcasting.

\section{EDUCATION AND TRAINING OF COMMUNICATORS}

3178 Watts, Frank. "ABC Activities in the Training of Overseas Educational Broadcasters,"' Educational Broadcasting International, 6, no. 3 (September 1973): 145-47.

Describes training programs conducted by Australian Broadcasting Commission, 1967-1972; trainees from Gilbert and Ellice Islands and other Pacific areas.

\section{GOVERNMENT INFORMATION ACTIVITIES}

3179 “'Sail Ho," PIM, 15, no. 8 (March 1945): 24.

Notes publication by Fiji government information office of a news magazine titled Sail Ho for the Gilbert and Ellice Islands.

3180 “GEIC Produces Local News Bulletin,” PIM, 25, no. 9 (April 1955): 87.

Notes appearance of monthly news bulletin published by GEIC government in English; joins two news sheets being published in local languages.

3181 "NZBC Officer for Gilbert and Ellice Islands," $A B U$, no. 82 (March 1972): 50 .

Reports that Howard Gough has been seconded to Unesco as broadcasting training expert to plan and conduct radio training courses in the Gilbert and Ellice Islands.

3182 “Newsletters Appear for Executive Officers," PICN, 5, no. 1 (February 1975): 9.

First edition of Teitei, a newsletter for Island Executive Officers, issued by the district office at Tabiteuea North in the Gilbert and Ellice Islands.

\section{RADIO BROADCASTING}

3183 "GEIC Broadcasting Service Progresses," PIM, 26, no. 2 (September 1955): 24.

Reports new building completed for Radio Tarawa (VTW); station broadcasts about one hour a day.

3184 MacDonald, Barrie. "Local Government in the Gilbert and Ellice Islands, 1892-1969,'” Journal of Administration Overseas, 10, no. 4 (October 1971): 280-93; 11, no. 1 (January 1972): 11-27.

Part two contains passing reference to unsatisfactory use of broadcasting and written propaganda in explaining 1966 local government ordinance. 
3185 Gough, Howard. "A Place Where Radio Means Everything," $A B U$, no. 91 (January 1973): 3-6.

Discusses use of radio in improving communication in Ellice Islands; information on classes to improve writing of broadcast messages and use of radio in inter-island communication.

3186 "Gilberts and Tuvalu Strengthen Radio Signal," PICN, 5, no. 4 (December 1975): 9 .

Installation of new studio center at Funafuti improves broadcast reception.

3187 "GEIBS becomes GIBS," $A B U$, no. 119 (January 1976): 6.

Major changes for the Gilbert and Ellice Islands Broadcasting Service in January 1976 due to independence of Ellice Islands. New radio station for Tuvalu; staff changes announced. Article reviewed in PICN, 6, no. 2 (June 1976): 7.

\section{SATELLITE COMMUNICATION \\ See also Pacific Islands General}

3188 "Links into Satellite," PICN, 5, no. 1 (February 1975): 9.

Announces beginning of operation of Tarawa satellite communication terminal. 


\section{Wallis and Futuna Islands}

NEWSPAPERS, PERIODICALS

3189 BULLETIN D'INFORMATION (du) TERRITOIRE DES ILES WALLIS ET FUTUNA. 1964-1971. Monthly; somewhat irregular. In French and Wallisien. Also issued a Wallisien (Uea) language edition, publishing details unavailable.

3190 FETUUAHO: LE PREMIER JOURNAL DU PACIFIQUE EN LANGUE POLYNESIENNE. Nouméa, June 1973_. Published in Wallisien language.

3191 JOURNAL OFFICIEL DU TERRITOIRE DES ILES WALLIS ET FUTUNA. Mata-Utu. 196? — - Official gazette; published monthly in French.

3192 MALAMA-FOOU. Wallis and Futuna. 1975_. Monthly. Published in Futunan and French.

\section{PRINTING}

3193 O'Reilly, Patrick. "Premiers Travaux des Presses de la Mission Catholique a Wallis (1845-1849)," Journal de la Société Océanistes, no. 19 (1963): 119-28.

\section{RADIO BROADCASTING}

3194 “'Television for the Loyalties," PIM, 46, no. 11 (November 1975): 80.

Mentions that Wallis and Futuna will soon be able to receive medium-wave radio; previously could only receive short-wave. 


\section{Western Samoa}

NEWSPAPERS, PERIODICALS

3195 APIA ADVERTISER. Apia. March 29, 1967-? Weekly in Samoan and English. Superseded Samoana (May 1960-March 1967). Incorporated The Sentinal (October 1961-February 1962), published in Vaimea, in 1962.

3196 APIA BEACH PRESS. Apia. April 1972-? Monthly in English.

3197 APIA EDITION. See Samoa Times. n.s.

3198 APIA WEEKLY. Apia. June 4, 1971-197? Weekly in Samoan and English.

3199 APIA WEEKLY. n.s. Apia. 1975-1976. Weekly.

3200 O LE SAVALI. See Savali.

3201 O LE SULU SAMOA. Salua. July 1890 - Monthly in Samoan; frequency varied.

Missionary journal with news and information.

3202 NEW ZEALAND SAMOA GUARDIAN. See Samoa Guardian.

3203 PACIFIC STAR. Apia. 1969-197? A weekly in Samoan and English.

3204 PUBLIC RELATIONS DIVISION. See Weekly Newsletter.

3205 ROYAL GAZETTE. Apia. 1892-1893. Official gazette.

3206 SAMOA BULLETIN. See Samoa Times. n.s.

3207 SAMOA GUARDIAN. Apia. May 26, 1927-February 20, 1930? Opposition newspaper; published in Auckland under title New Zealand Samoa Guardian (May 193?-1932?).

3208 SAMOA HERALD. Apia. July 1932?-? Weekly.

3209 SAMOA TIMES. Apia. April 1901-February 1930. Biweekly (1901-02), then weekly. Title varied: Samoanische Zeitung (April 1901-January 1915). In English and German from 1901-1917. 
3210 SAMOA TIMES. n.s. Apia. June 23, 1964- Weekly in Samoan and English. In 1967 absorbed Samoa Bulletin (November 1950-May 1967), a weekly in Samoan and English with Samoan-language title: Tusitala Samoa. For a time had editorial offices and different editions for American and Western Samoa. For a time from June 30, 1970, Western Samoa's edition titled Apia Edition.

3211 SAMOAN REPORTER. Upolo. March 1845-1862? Published twice yearly by the Mission of the London Mission Society.

3212 SAMOANA. See Apia Advertiser.

3213 SAMOANA-HERALD. Apia. November 1974-1976. Weekly.

3214 SAMOANISCHE ZEITUNG. See Samoa Times.

3215 SAMOANISCHES GOUVERNMENTS-BLATT. Apia. 1900-1914. Official gazette of the German Administration.

3216 SAVALI. Apia. September 1, 1905—. Monthly until about 1970, then biweekly. First in Samoan, now Samoan and English. Title varied: $O$ Le Savali. Published by Prime Minister's Department, Government of Western Samoa.

In January 1970, newspaper's style changed to include educational and informational articles and pictures.

3217 THE SENTINAL. See Apia Advertiser.

3218 SOUTH SEA STAR. Apia. 1971 — . Weekly in Samoan and English.

3219 TUSITALA SAMOA. See Samoa Times.

3220 WEEKLY NEWSLETTER. Apia. November 20, 1964-197? Suspended between October 1966-January 1967. Published in English by Public Relations and Publicity Division, Prime Minister's Department, Government of Western Samoa. First edition titled: Public Relations Division.

3221 WESTERN SAMOA GAZETTE. May 1920 - Official gazette started by New Zealand Administration and continuing with same title by Western Samoan Government. Irregular in Samoan and English. Issues for 1965-1972 available on microfilm from New York Public Library Photographic Service.

3222 WESTERN SAMOA MAIL. Apia. 1901-March 28, 1942. Weekly.

\section{GOVERNMENT AND INTERNATIONAL AGENCY REPORTS}

3223 New Zealand. Department of Island Territories. Report on Western Samoa, 1920/21-1960. Annual.

Chapter on transportation and communications; statistics on radio broadcasting, etc.

\section{CINEMA}

3224 Hall, Mordaunt. " "Nanook' Producer Here with Samoan Film Study," NYT, March 1, 1925, VII, 5: 1.

Feature article on the making of a film in Samoa. 
3225 “Samoan Setting for Film About Gilberts," PIM, 26, no. 2 (September 1955): 119.

Reports British film company, Lawrie Productions, will produce film "A Pattern of Islands" in Western Samoa for economic reasons.

3226 “The Censor Moves In," PIM, 42, no. 4 (April 1971): 32.

Reports revival of Censorship Committee, established in 1960 but rarely used until recently.

3227 “Sex Films, Long Hair, Upsetting Samoa MPs," PIM, 43, no. 1 (January 1972): 99.

Reports comments of members of Western Samoan Parliament on desired film censorship. Article states incoming films are censored twice: in country of origin, and then by Western Samoan Censorship Committee.

3228 "You Can Show It Like It Is But Not in Western Samoa," PIM, 43, no. 2 (February 1972): 61.

Discussion of film censorship.

3229 “'Sex Scares Samoa's Politicians,"' PIM, 43, no. 6 (June 1972): 22-23.

Discusses the zeal of censors in banning sex films.

3230 “'Blood, Sex and All That," PIM, 44, no. 5 (May 1973): 13.

Reports continuing bad relations between Western Samoan Censorship Committee and theater owners.

\section{COMMUNICATION RESEARCH}

3231 Keesing, Felix M., and Marie M. Keesing. Elite Communication in Samoa: A Study of Leadership. Stanford: Stanford University Press, 1956. 328 pp.

Case study of communication in Samoa, with particular emphasis on how elites communicate in different social situations; describes role of mass media in traditional communication systems.

3232 Pitt, David. Tradition and Economic Progress in Samoa: A Case Study of the Role of Traditional Social Institutions in Economic Development in Western Samoa. Oxford: Clarendon Press, 1970. 295 pp.

Deals with mass media in Western Samoa on pages $223 \mathrm{ff}$.

3233 "Survey of Government Control of Media," PICN, 2, no. 2 (August 1971): $1-4$.

Summarizes results of a survey by Ralph Barney on mass media and leadership attitudes in Western Samoa, American Samoa, Fiji, and Tonga.

3234 Barney, Ralph D. "Mass Media Roles in Development: A Descriptive Study from Four Developing Areas," Gazette, 19, no. 4 (1973): 222-38.

A study of the developmental news content of six newspapers, including Samoa Times and Pacific Star; content analysis revealed little evidence of systematic inclusion of development-oriented material in any of the six.

\section{EDUCATION AND TRAINING OF COMMUNICATORS}

3235 “Open Communication is Vital," PICN, 3, no. 1 (July 1972): 3.

Discusses needs and best methods of communication for agricultural officers. 
3236 McBain, Norman. "Extensive Training for Asian Broadcasters," $A B U$, no. 89 (October 1972): 17-21.

Describes training course in basic radio production and presentation organized by Unesco and Asian Broadcasting Union held in Apia in June 1972.

3237 Watts, Frank. "ABC Activities in the Training of Overseas Educational Broadcasters," Educational Broadcasting International, 6, no. 3 (September 1973): $145-47$.

Describes training conducted by Australian Broadcasting Commission 1967-1972; trainees from Western Samoa and other Pacific areas.

3238 "Tonga, Western Samoa, Tahiti Get Look at Video Tape," PICN, 4, no. 2 (December 1973): 3.

Describes travelling videotape recording training conducted by Christian Education and Communications Program.

3239 McBain, Norman. "Training in the Pacific," $A B U$, no. 100 (January 1974): 27-28.

Report on broadcast training courses sponsored by Unesco and the South Pacific Commission conducted in Western Samoa and elsewhere in 1973.

3240 "UNESCO Expert to Apia Post," PICN, 5, no. 2 (June 1975): 6.

Rural broadcasting expert Graham Thomas posted to Western Samoa for training program stressing education and information programming and production.

3241 Madison, Curt. "Apia Radio Center Opens," PICN, 5, no. 4 (December 1975): $1,4$.

Reviews Unesco Western Samoan Broadcast Training Project to train young adults in all phases of program production, with emphasis on village needs and news.

\section{EDUCATIONAL MEDIA}

Newspapers

3242 Thornton, Jack. "School Journals for Polynesia," PIM, 22, no. 9 (April 1952): 66-67.

Describes literature produced by School Publications Branch, New Zealand Education Department, for distribution in Western Samoa and other island areas; discusses editing, production, distribution.

\section{Radio}

3243 Educational Broadcasts to Samoan Village Schools. Technical Paper No. 14. Noumea: South Pacific Commission, $1951.7 \mathrm{pp}$.

A report on work to supplement classroom teaching by use of educational broadcasts prepared by the territorial education department of Western Samoa; describes development and content of broadcasts.

3244 Beeby, Clarence E. Report on Education in Western Samoa. Wellington: Government Printer, 1954. 39 pp.

Report presented to the New Zealand House of Representatives by the Department of Island Territories; contains some references to use of radio in education.

3245 Rankin, R. F. "How the Broadcast Lesson Overcomes Teacher Shortage," PIM, 26, no. 9 (April 1956): 89-91, 93.

Describes staffing, curriculum, conduct of programs broadcast; finds educational radio, with proper techniques, very effective. 
3246 "School Broadcasting in Western Samoa," Overseas Education (London), 28, no.3 (October 1956): 128-30.

Stresses that school broadcasting system proven effective in raising standards of education in its six years of operation; reviews system, programming.

3247 Hayden, Howard. "On the Quality of Education in the South Pacific," International Review of Education, 27, no. 2 (1971): 165-81.

A survey of South Pacific education systems and their problems; some reference to educational radio in Western Samoa.

\section{FREEDOM OF THE PRESS/BROADCASTING}

\section{8 "Suppression of the Mau Newspaper," PIM, 4, no. 7 (February 1934): 31.}

Reports official announcement declaring New Zealand Samoa Guardian a seditious newspaper and prohibiting its receipt in Western Samoa.

3249 "Should Speech be Free? Samoans Beg to Differ," PIM, 33, no. 9 (April 1963): 75-77.

Discusses speech in which Prime Minister criticizes newspapers and expresses view that freedom of speech should apply only to the matais, or chiefs.

3250 "Mataafa Threatens to Ban Newspapers in Western Samoa," PIM, 34, no. 1 (August 1963): 7-8.

Reports threats of Prime Minister to close Samoa Bulletin and Samoana due to their criticisms of the government.

3251 “Press Freedom in Samoa," PIM, 35, no. 3 (March 1964): 29.

Letter to editor regarding a United Nations report on government administration of Western Samoa published by Samoana against the wishes of the government.

3252 “Politicians Ban 2AP News," Apia Advertiser, December 6, 1967, p. 1.

Daily bulletin of local news from $2 \mathrm{AP}$ abruptly taken off the air due to political pressure from cabinet minister.

3253 "2AP Refuses to Broadcast Samoa Times Statement," Samoa Times, April 21-27, 1972, p. 1.

Only radio broadcasting station in country, 2AP, refused to broadcast Samoa Times statement about chief justice's office and its terms, in reply to the Prime Minister's article in Samoa Times and speech over radio.

3254 Va'a, Felise. "Island Press Disturbed by 'Invisible Censorship'," PIM, 43, no. 6 (June 1972): 32.

Reports government not now providing enough news releases, which hinders the local paper in providing news stories.

3255 Tuimavave, Tumele. “Under Fire," PIM, 43, no. 9 (September 1972): 121.

Letter to editor criticizes Felise Va'a's June 1972 article published in Pacific Islands Monthly. Tuimavave states that press freedom in Western Samoa now is better than in past.

$3256 \mathrm{Va}$ 'a, Felise. "On Freedom and Truth in Western Samoa," PIM, 43, no. 10 (October 1972): 30.

Va'a's critical reply to Tumele Tuimavave's letter to PIM editor, which was published in September 1972. 
3257 “Island Press Disturbed by Invisible Censorship," PIM, 43, no. 6 (June 1973): 32.

Discusses tension between Western Samoan newspapers, especially Samoa Times, and government.

\section{LEGAL ISSUES}

3258 “'Samoan Libel Action," PIM, 2, no. 10 (May 1932): 21.

Reports unsuccessful attempt of boxing promoter to win libel judgment against Samoa Herald.

3259 “Libel Case Fails: MLA vs. 'Samoa Bulletin'," PIM, 27, no. 9 (April 1957): 142-43.

Reports successful defense against libel suit brought by legislator against Samoa Bulletin.

3260 "Western Samoan Newspapers Go to Court," PIM, 31, no. 7 (February 1961): 121 .

Notes libel suit brought against Samoa Bulletin by Samoana.

3261 “Judgment in Samoan Newspaper Suit," PIM, 31, no. 9 (April 1961): 120-21.

Reports decision in suit involving Samoana and Samoa Bulletin.

\section{THE PRESS}

\section{General}

3262 Grattan, F.J.H. An Introduction to Samoan Custom. Apia: Samoa Printing and Publishing Company, 1948. $189 \mathrm{pp}$.

Note on page 142 lists vernacular publications then appearing.

3263 “New Weekly Newspapers in Islands," PIM, 21, no. 7 (February 1951): 35.

Notes agreement of government to distribute as yet untitled Samoan newspaper.

3264 Davidson, J. W. Samoa mo Samoa: The Emergence of the Independent State of Western Samoa. Melbourne: Oxford University Press, 1967. $467 \mathrm{pp}$.

A study of transition and political evolution in Western Samoa as a result of contact with the Western world; references to activities of various journalists and newspapers including New Zealand Samoa Guardian, Samoa Guardian, Samoa Bulletin, Samoa Times, Savali, Western Samoa Mail.

3265 Gilson, R. P. Samoa 1830 to 1900: The Politics of a Multi-Cultural Community. Melbourne: Oxford University Press, 1970. $457 \mathrm{pp}$.

Contains occasional references to positions taken on political issues by Samoan newspaper editors; bibliography provides good guide to manuscripts and official documents.

3266 Alailima, Leota Pita. "The Role of the Media in Economic and Social Development in Western Samoa." Paper prepared for South Pacific Editors' Conference, Suva, Fiji, July 30-August 5, 1972. Honolulu: East-West Center, Communication Institute, $1972.3 \mathrm{pp}$.

Paper stresses need of editor to understand his country's economic and social development plans; paper's role in promoting economic and social development in relation to the social customs of Western Samoa.

3267 “Paper Shortage Hits," PICN, 4, no. 4 (September 1974): 14.

Notes difficulties caused by newsprint shortage in Western Samoa. 


\section{Apia Advertiser}

3268 “" 'Samoana' Dies; New Paper Born,” PIM, 38, no. 4 (April 1967): 9.

Notes closing of Samoana due to stock dispute; information on new weekly paper, Advertiser.

Apia Weekly. n.s.

3269 Va'a, Felise. "Freedom to Perish," PIM, 47, no. 6 (June 1976): 12.

Reports financial difficulties have caused Apia Weekly, publishing for over a year, to cease.

\section{New Zealand Samoa Guardian}

3270 "Independent Paper Starts in Samoa," NYT, June 12, 1927, II-20: 3.

Reports appearance of Samoa Guardian; opposition paper.

3271 “Mr. Nelson Re-states Attitude of Mau," PIM, 3, no. 1 (August 1932): 26-27.

Letter from O. F. Nelson refers to his connection with the New Zealand Samoa Guardian.

3272 Correspondence of O. F. Nelson, January 16, 1928-April 21, 1933. Available on microfilm, Pacific Manuscripts Bureau.

Correspondence with H. E. Holland, leader of the New Zealand Labor Party, and with Nelson's wife, Rosabel, contains scattered references to New Zealand Samoa Guardian.

3273 "The Mau Cases in Samoa," PIM, 4, no. 7 (February 1934): 29, 31.

Describes sedition trial of O. F. Nelson; contains references to expenditures for the New Zealand Samoa Guardian, with which Nelson was connected. The New Zealand Samoa Guardian was banned from Western Samoa by a government order in 1933 as a "seditious" newspaper.

\section{Pacific Star}

3274 “Pacific Star Continued," Pacific Star, August 19, 1970, p. 1.

\section{Samoa Herald}

3275 "Samoa Herald: G. W. Griffith Assumes Editorship," PIM, 3, no. 7 (February 1933): 32.

Brief background of G. W. Griffith.

3276 "The Samoa Herald," PIM, 6, no. 5 (December 1935): 53.

Announces change of management of Samoa Herald, which reverted to previous owner, Samoa Times Printing and Publishing Company, after 16 months under G. W. Griffith.

\section{Samoa Times}

3277 “Weekly Paper for W. Samoa," PIM, 21, 4 (November 1950): 9.

Reports Samoa Times, new bi-lingual weekly paper, was first printed November 3.

3278 “'Samoan MLA's Resent Newspaper's Attacks," PIM, 22, no. 10 (May 1952): 95.

Criticizes Samoa Bulletin for coverage of the Samoan Legislative Assembly.

3279 Materials on Current Social, Economic, and Political Problems in Western Samoa, as Seen From Editorials and Correspondence in the Samoa Bulletin (1956-1957). Microfilm in Hamilton Library, University of Hawaii. 
3280 “Feelings Boil in Newspaper War," PIM, 30, no. 2 (September 1959): 51.

Reports former editor and directors of Samoa Bulletin having journalistic "hot-war" over issue of shortage of doctors.

3281 “The Role of the Press in Samoa," PIM, 32, no. 7 (February 1962): 23-24.

Discusses lack of interest in Western Samoa's Independence Day by the international press; gives some information on Samoa Bulletin.

3282 "Western Samoa Head Criticizes the Critics," PIM, 33, no. 7 (February 1963): 127.

Reports radio speech of Prime Minister Mataafa which criticized staffs of Samoa Bulletin and Samoana over their criticisms of government.

3283 “Island Newspaper to Change Hands," PIM, 37, no. 8 (August 1966): 145.

Discusses plans of owner of Samoa Bulletin to sell paper.

3284 “'Samoa-wide Newspaper is Created,"' $S$ - $B$, May 6, 1967, B-16: 3.

Samoa Times, Pago Pago, announces plans to merge with Samoa Bulletin, Apia; owners of former $S a$ moana involved; resulting paper to be known as Samoa Times.

3285 “Two Samoas Get Their First Joint Newspaper," PIM, 38, no. 6 (June 1967): 32.

Reports merger of Samoa Bulletin, Apia, and Samoa Times, Pago Pago.

3286 "S-B Subsidiary Has Option to Purchase Samoa Paper," $S-B$, August 21, 1970, 2: 1 .

Guam Publications, Inc., enters into option agreement to buy majority stock in Samoa Times.

3287 “'Samoa Newspaper Moves,” PIM, 41, no. 10 (October 1970): 109-110.

Discusses plans of Guam Publications, subsidiary of Honolulu Star-Bulletin, to buy majority control of Samoa Times; dispute between Samoa Times' two editors on where paper should be printed; history of the paper.

3288 "People," PIM, 41, no. 9 (September 1971): 93.

Reports Peter Creevey resigned as Managing Editor of Samoa Times; he was also Managing Editor of the old Samoa Bulletin before it merged with the Times.

3289 "'Samoana-Herald Appears; Times Ready for New Edition," PICN, 5, no. 1 (February 1975): 11.

Article includes note about Samoa Times; it was considering introducing a second edition.

\section{Samoana}

3290 "The Role of the Press in Samoa," PIM, 32, no. 7 (February 1962): 23-24.

Discusses lack of interest in Western Samoa's Independence Day by the international press; gives some information on Samoana.

3291 "Western Samoa Head Criticizes the Critics," PIM, 33, no. 7 (February 1963): 127.

Reports radio speech of Prime Minister Mataafa which criticized staffs of Samoa Bulletin and Samoana over their criticisms of government.

3292 “ 'Teach Yourself’ Editor Beats the Gun,” PIM, 33, no. 11 (June 1963): 25.

Reports Samoana published details of government report before government released it; reviews paper's history. 
3293 “Press Freedom in Samoa,” PIM, 35, no. 3 (March 1964): 29.

Letter to editor reports that after Samoana published an unreleased government report, the Samoana's editor, Bob Rankin, has been investigated by government.

3294 “Newspaper World Abuzz,” PIM, 37, no. 2 (February 1966): 14.

Describes dispute among shareholders of Samoana.

3295 “Island Newspaper to Change Hands," PIM, 37, no. 8 (August 1966): 145.

Includes information on dispute between stockholders of Samoana.

3296 “'Samoa-wide Newspaper is Created," $S-B$, May 6, 1967, B-16: 3.

Samoa Times, Pago Pago, announces plans to merge with Samoa Bulletin, Apia; owners of recently closed Samoana involved; resulting paper to be known as Samoa Times.

3297 “ 'Samoana’ Dies; New Paper Born,” PIM, 38, no. 4 (April 1967): 9.

Notes closing of Samoana due to stock dispute; information on new weekly paper, Advertiser.

\section{Samoana-Herald}

3298 “Samoana-Herald Appears; Times Ready for New Edition." PICN, 5, no. 1 (February 1975): 11.

Samoana-Herald, a weekly started by former members of the South Sea Star, begins publication.

3299 Va'a, Felise. "Freedom to Perish," PIM, 47, no. 6 (June 1976): 12.

Reports that financial difficulty has caused the demise of Samoana-Herald, published for over two years.

\section{Savali}

3300 “Being Educated for Independence," PIM, 30, no. 7 (February 1960): 22.

Notes changes in content and publication schedule of Savali, monthly newspaper published by government of Western Samoa.

3301 “New Look for Samoan Paper,"' PIM, 30, no. 7 (February 1960): 121.

Short item on changes in government newspaper, Savali.

\section{Western Samoa Mail}

3302 “'Samoan Newspaper Suspends," PIM, 12, no. 10 (May 1942): 17.

Reports suspension of Western Samoa Mail.

3303 “'About Islands People," PIM, 15, no. 9 (April 1945): 4.

Notes sale of Western Samoa Mail, by proprietor J. W. Liston to Samoa Printing and Publishing Co., formed by E. F. Paul.

\section{PRINTING}

3304 Churchill, W. "The Earliest Samoan Prints," Journal of the Polynesian Society, 24 (1915): 65-68.

Discusses missionary printed materials of the period 1836-1839.

3305 Goodall, Norman. A History of the London Missionary Society, 1895-1945. London: Oxford University Press, 1954. $640 \mathrm{pp}$.

Contains references to mission printing activities on pages 363-364. 


\section{RADIO BROADCASTING}

3306 “Apia Broadcasting Station," PIM, 2, no. 5 (December 1931): 41.

Reports opening of privately owned broadcasting station.

3307 "Radio in Samoa," PIM, 3, no. 6 (January 1933): 5.

Report on number of radio listeners and revenues from radio-telegraph business.

3308 “No German Broadcasts," PIM, 7, no. 8 (March 1937): 51.

Short report from correspondent denying Samoa listening to attacks on British rule from German stations.

3309 "Samoa Startled," PIM, 10, no. 6 (January 1940): 7.

Samoa residents reported startled by Nazi reports of unrest in Samoa.

3310 “Radio Broadcasts for Western Samoa," PIM, 17, no. 3 (October 1946): 31.

Reports plans of Western Samoa administration to create a Samoan Broadcasting service and to install receivers and loudspeakers in villages.

3311 "Broadcasts for Natives: Plans in Samoa and New Guinea," PIM, 17, no. 8 (March 1947): 58.

Discusses plans of government to use broadcasts for informational programs.

3312 “For Apia's New Broadcasting Station," PIM, 18, no. 5 (December 1947): 36.

Reports appointment of officer-in-charge of radio station being built for Samoan government by New Zealand Broadcasting Service.

3313 “Apia Radio Now Part of Samoan Life,” PIM, 19, no. 2 (September 1948): 6. Short item on the programming and popularity of station $2 \mathrm{AP}$.

3314 Rose, A. H. T. "Radio in Samoa," New Zealand Listener (Wellington), 21, no. 525 (July 15,1949$): 7$.

3315 "W. Samoa Legislative Assembly Keenly Debates Territory Affairs," PIM, 20, no. 5 (December 1949): 66-67, 69-70.

Short reference to discussion of interest in programming on government radio station.

3316 Grenfall, William J. "Broadcasting in Western Samoa," in Radio in Fundamental Education in Underdeveloped Areas. Paris: Unesco. 1950. pp. 73-82.

Reviews history of broadcasting since 1948, including special programs; organization of station for two languages, statistics on usage.

3317 “Broadcasting in W. Samoa," PIM, 23, no. 4 (November 1952): 66.

Reports radio very popular with Western Samoans; Legislative Assembly meetings and spiritual music led list of popular programs.

3318 "W. Samoa Testing on Short-Wave," PIM, 23, no. 10 (May 1953): 38.

Notes test broadcasts conducted by $2 \mathrm{AP}$, Apia, on shortwave; will parallel medium-wave broadcasts.

3319 “Apia Short-Wave Transmissions,” PIM, 24, no. 1 (August 1953): 114.

Notes delay in test broadcasts.

3320 "Western Samoa Testing New Short Wave Channels," PIM, 24, no. 2 (September 1953): 45.

Reports test broadcasts by Samoan Broadcasting Service on shortwave intended to improve coverage. 
3321 “Changes in Islands Broadcasts," PIM, 24, no. 3 (October 1953): 87.

Roundup of frequency changes for shortwave broadcasts.

3322 Thornton, Jack. “Retirement of Popular Radio Man,” PIM, 25, no. 11 (June 1955): 62 .

Sketch of Desmond Fahey, superintendent of telecommunication station at Apia; includes some background of development of broadcasting service at $2 \mathrm{AP}$.

3323 “'Broadcasting in the Pacific," $S P B, 6$, no. 4 (October 1956): 41-45, 56.

Describes broadcasting facilities in various Pacific Island areas.

3324 "Samoan Listeners Also Cheat," PIM, 30, no. 3 (October 1959): 117.

Reports Samoans' failure to pay radio license fees.

3325 “West Samoan Station Gets More Power," PIM, 32, no. 1 (August 1961): 7.

Notes installation of new transmitter at Afiamalu.

3326 Netram, Salma. "The Samoan Broadcasting Service," $A B U$, no. 72 (April 1971): 5-8.

Describes development and history of Samoan Broadcasting Service; information on operations, programming, plans for expansion.

3327 “2AP Prepares for Second Channel,” PICN, 5, no. 1 (February 1975): 11.

Station 2AP missing studio-transmitter link needed to start broadcasting.

\section{TELEVISION}

3328 “Samoa Prepares for Its (Educated) Goggle Box," PIM, 33, no. 2 (September 1962): 53-4.

Article about introduction of TV into American Samoa relates that government officials in Western Samoa and Tonga have had informal talks about TV reception for their islands.

3329 Rankin, R. F. “Western Samoa Cautious Over Neighbor's TV," PIM, 35, no. 12 (December 1964): 51, 53.

Discusses Western Samoan interest in American Samoan television system.

3330 "Race is on for First Samoan TV Sets," PIM, 36, no. 1 (January 1965): 17.

Notes good reception of television signals from American Samoa in Apia and controversy over duty to be paid on television sets.

3331 Madison, Curtis. "Samoan Television: A Questionable Gift," PICN, 6, no. 2 (June 1976): 5.

Reviews problems inherent in Western Samoan Government's accepting television from American Samoa; would require American television equipment to be used.

3332 “Television Station for Western Samoa? KVZK-TV Offer," PICN, 6, no. 2 (June 1976): 1.

American Samoa TV equipment, no longer used due to cutbacks in educational television project, offered to Western Samoa; offer to Tonga in very preliminary stage. 


\section{INDEX}

Numbers refer to entries, not to pages.

A'Beckett, Arthur W., 623
ABU Newsletter, 49
ABU Technical Review, 50
Action Bulletin, 3039
Adams, Charles, 1969
Adamski, Mary, 1584
Adloff, Richard, 908
Advertiser, 299
Agar, T. C., 592
Ka Aha Elele, 1144

Alailima, Leota Pita, 151, 152, 156, 3266

Ke Alakai o Hawaii, 1129

Alden, John E., 3126

Allen, Bryant J., 2579

Allen, Gwenfread, 1487, 1488

Allen, Riley H., 1375, 1485, 1612, 1831

Allo Tahiti, 805

Aloha, 1111

Ke Aloha Aina, 1130

Aloha Broadcasting Corp., 2152

Aloha Daily News, 1647

Altonn, Helen, 353

Amalgamated Wireless (Australasia), Ltd., 170, 696-705, 710, 711, 2753, 2755

Amalu, Sammy, 2048

American Federation of Radio and Television Artists, 2055, 2061, 2107

American Newspaper Guild, 1527, 1531

American Samoa, Department of Education, 316, $317,325,331,341$; Governor, 318, 416; Office of Samoan Information, 381, 396, 398, 419

Amerika Samoa, 300

L'Ami des Tahitiens, 806

Amini, Brian, 2643

Amos, M., 2573

Anaki, Dean, 2432

Anderson, Burt, 2186

Anderson, Jon A., 380, 3092

Anderson, William A., 1406
Ando Madô, 2322

Anglade, Michel, 910, 912, 928

Another Voice, 1131, 1648

Anthony, J. Garner, 1489

Anthony, James, 628

Apia Advertiser, 3195,3268

Apia Beach Press, 3196

Apia Edition, 3210

Apia Weekly, 3198, 3199, 3269

Apple, Margaret, 2014

Te Ara o Oteania, 807

Te Ara Raa, 856

Te Aratai, 808, 907

Arawa Bulletin, 2482

Arek, Paulus, 2549, 2551

Armstrong, Dianne, 1425

Army Navy Veteran Review, 1111

Arua, Boe, 2803

Arvidson, K. O., 779

Asia-Pacific Broadcasting Union, 49, 50, 142, $2597,2598,2838$

Associated Press, 1558, 1816

Atoll Pioneer, 932, 949

ATS (Applications Technology Satellite), 216, $217,219,220,222,235,237,242,253,264,277$, $2137,2143,2144$

Ke Au Hou, 1184

Ke Au Okoa, 1308

Auckland Journal, 108

Aurora Hawaiiana, 1281

Austin's Hawaiian Weekly, 1135

Australian Broadcasting Commission, 594, 735, $743,2364,2580,2603,2606,2612,2629,2631$, $2660,2761,2762,2764-2766,2769,2771,2774$, $2775,2781,2784,2787,2790,2803,2805,2808$, $2815,2819,2915$

Australian Digest, 2484

Australian External Territories, 2486

Australian Government Digest, 2484 
Australian Government News, 2484

Australian National Commission for Unesco, 1

Australian School of Pacific Administration, 59, 2589

Australian Territories, 116, 2486

Avant Garde, 2323

Baker, Byron, 2190

Baker, J. C., 2640

Baksh, S., 524

Balk, Alfred, 1955, 1960

Ballou, H. M., 1977

Balob Teachers College, 2612

Banan Tungavalu, 933

Barber, Richard J., 1414, 1418

Barker, Alport, 654, 655

Barnard, Herbert, 2996

Barnes, Bruce, 1523

Barnes, C. E., 2665

Barney, Ralph D., 23, 71-73, 215, 322, 588, 2968

Barrett, Donald, 2795

Barton, Hugh, 1093

Basilius, Bonifacia, 3088

Baskett, Geoffry, 2758

Bassett, W. K., 1800-1802

Beacon, 1111, 1136, 1649

Beales, Peter, 458

Beeby, Clarence E., 3244

Bell, Janet E., 1627

Belshaw, Cyril, 748

Bennett's Own, 1210

Benson, Bruce, 246, 247, 249, 1784, 1865, 2112

Benstead, Gilda, 786

Berger, Lawrence S., 450-452, 455, 456, 2053, 2070

Berkowitz, David A., 224

Berry, Paul C., 326

Big Islander, 1924

Bingham, Hiram, 1972

Bishop, Carolyn, 342

Bishop, Robert, 342

Bisnis, 2676

Bitterman, Mary, 1479

Black, Cobey, 1376

Black and White, 2488, 2677

Blair, William M., 388

Blankenburg, William B., 1958

Bleek, William H. I., 163

Blickhahn, Harry, 1719

Blundell, Margaret, 276

Bondu, Melchoir, 1919

Borreca, Richard, 1589

Borrows, Edwin G., 1657

Borsch, Ferd, 2057

Boswell, Douglas, 2218

Bougainville News, 2489, 2678

Bowman, D. N., 2662

Bowman, Pierre, 1636, 2082, 2224

Boyack, James, 909, 911,928

Boyer, Jack, 1996

Bracken, Lawrence, 419

Bradley, Harold W., 1614

The Breeze (Hawaii), 1650

The Breeze (Johnston Island), 2301

Briggs, Asa, 202
British Broadcasting Corp., 184, 202, 800, 2313 British New Guinea Government Gazette, 2521

British Newsletter, 2398, 2407

British Solomon Islands, Dept. of Post and Telecommunication, 2879

British Solomon Islands Protectorate Gazette, 2875

British Solomon Islands Protectorate News Sheet, 2876

Broadbent, Derek, 2613

Brockhall, J. F., 2608

Brooke, Douglas, 2613

Brosnan, John, 2158, 2159, 2238

Brown, Don B., 1926

Brown, J. Edward, 506, 2431, 2432

Bruckner, Doug, 2202, 2297

BSI News Sheet, 2876

B.S.I.P. News Sheet, 2876

Buckets, 3015, 3105

Buick-Constable, L. M., 92

Buka News, 2491, 2679

The Bulletin (Nauru), 2304

Le Bulletin (New Hebrides), 2392

Bulletin Commercial, 810

Bulletin d'Information de la Residence de France aux Nouvelles-Hebrides, 2392

Bulletin d'Information du Territoire des Iles Wallis et Futuna, 3189

Bulletin du Comité Pouvanaa, 808

Bulletin du Commerce de la Nouvelle Calédonie et des Nouvelles Hebrides, 2345, 2358

Bulletin du Rassemblement Democratiques des Populations Tahitiennes, 808

Bulletin du Vicariat, 529

Bulletin of the Pan Pacific Union, 1111, 1640

Bulletin Officiel de la Nouvelle-Calédonie, 2325

Bulletin Officiel des Établissements Français de l'Océanie, 811

Burk, Gay, 1467

Burrell, Shelley, 2089

Burris, Jerry, 1507, 1591, 1696, 2225, 2226

Byers, Burton $\mathrm{H}_{\text {, , }} 2132$

Bystrom, John W., 217, 222, 225, 229, 230, 237 , $258,262,266,267,274,290,293,294,2147$

Cablecom-General, Inc., 2213

Cabrinha, A. M., 1562

Le Caillou, 2326

Le Caldoch, 2360

The Caledonian Island, 2360

Les Calédoniens, 2327

Callison, George T., 268, 3147, 3160

Camp, Inc., 2230

Le Canard Tahitien, 812,903

Capitol Correspondents' Association (Hawaii), 1948

Carano, Paul, 1069

Carib, Ralph, 357

Carlson, Douglas, 1590, 1595

Carmichael, Dan, 1646

Carney-Rowan, Sandra, 1420, 2433, 2436, 2578. 2821, 3073

Carolines Observer, 3016

Carter, G. R., 1977

Carter, J. O., 1607 
Carter, John, 139

Case, Howard D., 1610

Casey, Brian, 1495

Casserly, Pat, 2599

Catholic Herald, 1138, 1678-1680

Catholic Radio Production Center, 3076

Caton, Nancy, 1091

Central District News, 2869

Central Pacific Post, 2305, 2316

Chang, Kuo-sin, 1661

Channell, Douglas, 2778

Chaplin, George, 354, 355, 1570, 1580, 1593, 1792

Chapman, Ronald, 1868

Chase, Martyn, 372

Chatterton, Percy, 2625, 2813

Cheifet, Stewart, 379

Chock, Lun, 1655

Christian, Thomas C., 2862

Christian Communications Commission, 2587, 2588

Christian Education and Communications Program, 893

Christian Radio Missionary Fellowship, 186

Chun, Chee Kwon, 1654

Chung Hua Hsin Pao, 1139, 1661

Churchill, W., 3304

Ciciqadry, 2328

Cirino, Robert, 1644

The Citizen, 1339, 1662, 1897

Clark, F. P., 1079

Cleland, Lindsay, 2

La Cloche, 813

Cockcroft, John, 757, 758

Codding, George A., Jr., 194

Coffman, Tom, 1639

Cole, Allan V., 86

Coleman, H. A., 2439

Coll, Raymond, 1749, 2169

Collado, Doroteo M., 1911

Collins, K. G., 719

Colony Information Notes, 932, 949

Commercial Hawaii, 1237

Commercial Times, 1340

Communication, 1142

Communications Honolulu, Inc., 2268

Communications Satellite Corp. (COMSAT), 2183-2185, 2189

Communico, Inc., 2086

Community Review, 1143, 1665

La Concierge, 814, 898

Congress of Micronesia, 1075

Conroy, F. Hilary, 1877, 1878

Constructionnaire, 961

The Convention, 1144

Cook Islands Gazette, 464

Cook Islands News, 465, 483, 484, 486, 488

Cook Islands Photo News, 467

Cook Islands Radio Manufacturing Cooperative Society, Ltd., 510

Cook Islands Review, 467, 481, 482, 485

Coombs, Philip H., 328

Cooney, Stuart, 347

Copley Press, Inc., 1776, 1777, 1782, 2064

Coppell, William G., 3, 463, 475, 487, 489, 2674, 2720, 2743
Corail, 2329

Cormack, James E., 479

Costa, Abelina M., 225, 2123

Costa, Benet, 1923

Coughlin, Dianne, 1648

Coulter, John W., 1654

Council on New Guinea Affairs, 2508

The Councillor, 2680

Courrier de Tahiti, 815

Le Courrier des E.O.F., 816

Le Courrier Illustré de la Nouvelle Calédonie, 2330,2362

Crane, Ezra, 1944

Cranfield, C. A., 672

Creamer, Beverly, 233, 2216

Creevey, Peter, 3288

Crozier, Mary, 193

Cunningham, James F., 1800, 2108, 2109

Cutting, Alan, 224

Daily Bulletin, 1230, 1868

Daily Hawaiian, 1147

Daily Hawaiian Herald, 1148

Daily Herald, 1146

Daily Honolulu Press, 1149

Daily Pali Press, 1370, 1701, 1703

Daily Post-Herald, 1203

Damon, Ethel M., 1377

Damon, Samuel C., 1377

Daniel, Lark, 375

Danielsson, Bengt, 905

Darlow, T. H., 164

Darr, Bert, 2272

Davidson, J. W., 3264

Davies, F. R. J., 473

Davis, Eleanor H., 1378

Day, A. Grove, 1379, 1988, 1993, 1996, 1999, 2015

Les Débats, 817

Les Dégats Libérés, 818

DeMello, Milton, 333, 378

The Democrat, 1152

Democratic News, 490

La Dépêche de Tahiti, 819, 892, 904, 910, 912

Derrick, R. A., 626

Desha, Eddie, 1736

De Young, John E., 94, 602

Diamond, A. I., 520

Dibble, Sheldon, 1971

Dickson, Diane, 4

Didil A Chais, 3017

Dispatcher, 1153

Dixon, J. B., 1898, 1924

Donchin, Gwyneth, 3146

Donham, Buck, 1506, 1581

Donohew, Lewis, 2570

Dordick, H. S., 1409

Dornbusch, Charles E., 6

Dossor, Carol, 4

Douglas, Himalea, 212, 2441

Duiger, David, 2574

Duisiga, 530, 632, 633

Duncan, Hobert E., 1496-1499

Dunlap, Sky, 1556

Du Teil, Claude, 1949

Dutton, Meiric K., 1380, 2000 
East-West Communication Institute, 7, 53, 121$127,278,1412$

Eastern News, 2871

Eaton, A. M., 2401

Eaton, Richard, 2273-2276

Ebara, Hachirō, 1884

Ebrey, Mark, 653

L'Écho, 820

L'Echo de Tahiti, 821, 822

Echo du Lagon, 823

Échos de Polynésie, 825, 903,904

Échos de Tahiti, 824

Echos of Polynesia, 826

Economic Salon, 1158

Economic World, 1158

Educational TV Foundation of Hawaii, 1941-1943

Edwards, Edwin R., 1871

Eguchi, George, 1713

Eigsti, Steve, 458

Electronic Industries, Ltd., 793

Ka Eleele, 1273

Ka Eleele Poaopo, 1273

Ka Eleele Poakolu, 1273

Elkin, A. P., 118

Ellis, William, 914

Embree, John F., 3095

Emery, Walter B., 203

Emmett, Brian P., 583

Engee, P., 2847

Engle, Murray, 2074, 3082

Engledow, Ed., 396-398

Engler, Nicholas A., 235

Ennane, 3018, 3114

L'Equite, 827

Erakrik, Judah, 204

ESG Notes, 3019

Evening Bulletin, 1230, 1868

Evinger, Jane, 280, 1473

Ewing, William, 1376, 1831

Fa'alopo, Fa'alepo, Jr., 323

Fa'asamoa Pea, 301, 420

OFacho, 1160

Fahey, Desmond, 3322

Failauga Samoa, 395

Farace, R. Vincent, 2570, 2571

Farrington, Elizabeth (Mrs. W. R.), 1834-1836

Farrington, Wallace R., 1375, 1381, 1934

Fasi, Frank F., 1492, 1493, 1508-1513, 1515-1517, $1520,1587,1589-1600,1646,1853,1948$

Fawcett, Denby, 1785

Le Fei, 828

Feliciano, Grace, 2227

Feng, Ai-chün, 1660

Feng, Tzu-yu, 1658

Ferguson, John A., 2414

Fern, C. J., Jr., 1673

Fern, Stewart, 1699, 1700

Te Fetia Aratai, 829

Fetuuaho: Étoile du Matin, 2331

Fetu'u'o Tonga, 2926, 2959, 2968

Fiedler, Martha L., 339

Fiji, Broadcasting Commission, 582, 709-712, $717,719-724,727-731,733-736,738,741,745$, $747,749,752,753,755,757-773$; Broadcasting
Review Committee, 583; Central Archives, 521525

Fiji Argus, 532

Fiji Beach Press, 533, 634, 635

Fiji Catholic Gazette, 569

Fiii Film and Photo News, 535

Fiii Gazette and Central Polynesian, 544

Fiji Guardian, 538, 636-639

Fiji Holiday, 539

Fiji Information, 540

Fiii Nation, 541

Fiji National Training Council, 597, 599

Fiii Police Magazine, 640

Fiji Press Club, 692

Fiji Royal Gazette, 544

Fiji Samachar, 545, 641

Fiii Sandesh, 546

Fiji Sport, 547

Fiji Sun, 548, 591, 642-653

Fiji Television, Ltd., 794

Fiji Times, 549, 590, 591, 609, 654-676

Fiii Tourist Gazette, 551

Fiji Vritant, 552

Fiii Woman and Home, 553

Fijian Weekly News and Planters' Journal, 554, 677

Fisher, Gerald P., 1705

Fitzgerald, John A., 2669

Flores, Joseph, 1020, 1021, 1070, 1089

Focus New Guinea, 2492

Fogel, Howard H., 673

Fong, Alison, 788

Fonua, Siosiua H., 100, 2969, 2970

Ford, Alexander H., 1640

Foreign Broadcast Information Service, 9

Fornander, Abraham, 1378

4PM, 2756, 2836

4TO, 171, 176, 177

France Australe, 2332, 2352, 2354, 2358

France A ustrale Dimanche, 2333

Frankel, Chuck, 2183

Franklin, Karl J., 2668

Frater, Maurice, 2416

Frazer, Thomas L., 2572

Frear, Walter F., 1616

Free Press, 3020, 3106

Freund, A. P. H., 2633

Friedman, Bruno, 96, 257

The Friend, 1111, 1161, 1603, 1666-1668

Friendly Broadcasting Co., 1575-1577, 2273-2275

Friendly Isle News, 1162, 1669

Friends of Micronesia, 3021

Fujii, Jocelyn, 2087

Fusimalohi, Sione T., 2998

Galis, K. W., 2659

Gandhi, Nat, 629

Gannett Co., 1072, 1073, 1857-1859, 1862

Garamut, 2493, 2681-2683

The Garden Island, 1163, 1670-1676

Garden News, 1374

Garth, Arthur, 1942

Gauguin, Paul, 830, 841, 858, 900, 905

Gee, Harriet, 1600

Gereben, Janos, 2039 
Gibbings, Robert, 63

Gibson, J. A., 2791

Gibson, R. P., 3265

Gilbert and Ellice Islands Colony Gazette, 936

Gilbert Islands Broadcasting Service, 958

Gilbert Islands Gazette, 936

Glasman, A. L., 2248

Glatzer, Hal, 2113

Glenister, Roy, 2769

Glimpses, 963

Good News Press, 3048

Goodall, Norman, 3305

Goodell, Dale, 2140

Goodey, R. P., 2745

Goodman, L. R., 2605, 2606

Goodwin, W. P., 91

Gordon, J., 1405

Gordon, Morton J., 1450

Goss, J. W., 385, 387, 388

Gough, Howard, 944, 3185

Government Gazette (Nauru), 2310

Government Gazette; British Administration of German New Guinea, 2494

Grace, Donald J., 1414

Grace, Louis K., 1734

Grattan, F. J. H., 3262

Gray, John A. C., 395

Greene, Arthur A., 416

Greer, Richard A., 394, 1624

Grenfall, William J., 2602, 3316

Grey, George, 163

Griffin, James, 2678

Griffin, John, 250, 329

Griffith, G. W., 3275, 3276

Grimes, Paul, 109, 1963

Guam, University of, 999, 1001, 1095

Guam Advertiser, 965, 1016

Guam Bulletin, 966, 1017

Guam Daily Mirror, 967

Guam Daily News, 983, 1008, 1018-1024, 1070

Guam Echo, 969

Guam Examiner, 970

Guam News, 983, 1018-1024

Guam News Letter, 972, 1025-1040, 1067

Guam Profile, 973

Guam Publications, Inc., 440, 441, 1014, 1015 , $1070,1071,1601,3101,3118-3120$

Guam Recorder, 960, 974, 975, 1041-1069, 1077

Guam Times Weekly, 976

Guam Villager, 977

Guam Weekly Bulletin, 978

Guam Weekly Examiner, 979

Le Guepes, 830, 900, 905

Guinea Gold, 2684

Gulick, Sidney L., 1653

Gwyther-Jones, Roy E., 2577, 2587

Haas, Anthony, 486

Hadlow, Martin, 291, 2822, 2830

Ka Hae Hawaii, 1165, 1166

OKa Hae Katolika, 1167

OKa Hae Kiritiano, 1168

Hagadone Newspapers, 1706

Haggett, R. Geoff, 2988

Haimanava, 1169
Halesworth, Brian, 2609, 2610

Hall, Edward T., 3064

Hall, George, 345

Hall, Mordaunt, 3224

Hall, Roy J. D., Jr., 348

Hallard, Marie, 1904

Halliday, Lex, 65

Hamilton, Thomas H., 1962

Handy, Willowdean C., 1107

Hanley, Anthony, 241, 253, 269, 277, 516

Harada, Wayne, 2067, 2192

Harding, George L., 916, 917

Hardy, Thornton S., 1381

Hari Dina, 2495, 2685, 2686

Harms, L. S., 237, 1414, 1523

Harrison, DeSales, 2268

Hatanaka, Yuriko, 1889

Haugen, Keith, 1786

Hawaii, Department of Education, 1108-1110, $1437,1439,1442,1443,1478$; Governor's Advisory Committee on Educational Television, 1435, 1436; Legislative Auditor, 1444, 1445, 2225; Public Broadcasting Authority, 1478; U.S. Military Governor, 1482, 1489, 1490, 1494; University, 45, 217, 219, 221, 225, 227, 228, 246, $247,253,258,270,271,274,282,372,1440$, $1478,1507,2112,2113,2115,2132,2140,2143$, 2425

Hawaii, 1111, 1170, 1171

Hawaii AFL News, 1172

Hawaii Agriculture, 1111

Hawaii Business, 1173

Hawaii Business News, Ltd., 2080

Hawaii Catholic Herald, 1138, 1678-1680

Hawaii Chinese Journal, 1174

Hawaii Chinese Weekly, 1175

Hawaii Democrat, 1176

Hawaii Educational Association, 1460, 1463

Hawaii Farm \& Home, 1111

Hawaii Farm Monthly, 1177, 1681

Hawaii Farm Science, 1111

Hawaii Free People's Press, 1178

Hawaii Free Press, 1178, 1682

Hawaii Herald (Hilo), 1180

Hawaii Herald (Honolulu), 1182, 1683

Hawaii Hōchi, 1182, 1385, 1399, 1626, 1683-1694

Hawaii Holomua, 1183, 1184

Hawaii Journalism Review, 1185

Hawaii Kukala Pili Aupuni, 1187

Hawaii Labor News, 1188

Hawaii Library Association, 1111

Hawaii Mainichi Shinbun (Hilo), 1189

Hawaii Mainichi Shinbun (Honolulu), 1190

Hawaii Media, 1191

Hawaii Medical Journal, 1111

Hawaii Military Sun Press, 1192

Hawaii News, 1562

Hawaii News Service, 1695

Hawaii Newsmen's Association, 1946, 1947

Hawaii Newspaper Agency, 1769, 1770, 1773

Hawaii Newspaper Guild, 1524, 1527, 1530, 1532, 1557,1559

Hawaii Newspaper Publishers Association, 1419 , $1556,1944,1945$

Hawaii Observer, 1193, 1696 
Hawaii Post, 1203

Hawaii Press Newspapers, 1534, 1535, 1552, $1697-1706$

Hawaii Progress Holomua, 1195

Hawaii Puka La Holomua, 1196

Hawaii Residents' Association (Imua), 1402

Hawaii Sentinel, 1197

Hawaii Shinpō, 1198

Hawaii Sports Magazine, 1199

Hawaii Sportsman, 1111

Hawaii Star, 1228, 1707, 1708

Hawaii State Newspapers, 1697, 1698

Hawaii Kai Sun Press, 1186

Hawaii Times, 1202, 1387, 1563, 1574, 1709-1717

Hawaii Tribune-Herald, 1203, 1557, 1562, 1718 1730

The Hawaiian, 1204

Hawaiian-American 1205

Hawaiian Broadcasting System, 2156, 2171, 2235 , 2243, 2244

Hawaiian Commerical Journal and Maritime Report, 1206

Hawaiian Digest, 1111

Hawaiian Gazette, 1207

Hawaiian Historical Society, 1113

The Hawaiian Luminary, 1972

Hawaiian Paradise Park Corp., 1575-1577, 2271. 2273-2275

Hawaiian Spectator, 1208

Hawaiian Star, 1230, 1868

Hawaiian Teamster, 1201

Hawaiian Telephone Co., 2181-2183, 2185, 2186, $2188,2189,2198,2210$

Hawaiian Times, 1210

Hayden, Howard, 477

Haydon, John M., 373, 374, 383, 390, 391, 393 , $399-415,461,462$

Heads and Hands, 3022

Hebdomadaire, 2334

Hedstrom, I. M., 745

Heftel, Cecil L., 2056

Heftel Broadcasting Corp., 2058

Hein, Gerald F., 235

Heine, Carl, 3086

Heldt, Fred, 1676

Helper, 2687

Helton, William 226

Henderson, John W., 11

Henry, Albert, 490

Herald, 1211

Herald and Weekly Times, Ltd., 675, 2702

Hercules Broadcasting Co., 2079

Hervey, W. D., 1995

Hewitt, Arthur R., 12

Hewlett, Frank, 373, 1804

Highlander, John P., 2042-2044

Highlights, 3023

Hila, Morea, 2836

Hill, William, 1724, 1729

Hilo Daily Tribune, 1203

Hilo Rain, 1213

Hilo Times, 1214

Hilo Tribune, 1203

Hindi Journalists Union, 693

Hiri, 2496, 2646, 2688
Hitchcock, David I., Jr., 3071, 3103, 3104

Ho, Chinn, 1838, 1839, 1843, 1850

Ka Hoaloha, 1217, 1734

Hogue, Charles E., 1989

Ka Hoku Loa o Hawaii, 1218, 1735

Ka Hoku o Hawaii, 1219, 1736

Ka Hoku o ka Pakipika, 1220

Ka Hoku Pakipika, 1221

Hollinger, Fin, 2041

Holmes, Jean, 1674

Holmes, Lee M., 1103

Ka Holomua, 1222

Home Rula Republalika, 1223

Honda, Edwin, 2217

Honolulu, 1111, 1224, 1738

Honolulu Advertiser, 13, 1112, 1225, 1382, 1391, $1399,1407,1411,1510,1529,1532,1536-1551$, $1553,1554,1559-1561,1564,1565,1567-1572$, $1580,1583,1591-1593,1596-1600,1626,1739$ $1796,2002,2018,2252-2268$

Honolulu Chamber of Commerce, 1438

Honolulu Chronicle, 1363, 1923

Honolulu Community Media Council, 1510 , 1949-1968

Honolulu Daily Times, 1227

Honolulu Mercury, 1111

Honolulu Press Club, 1622, 1623

Honolulu Record, 1228, 1797-1814

Honolulu Republican, 1229

Honolulu Star-Bulletin, 13, 119, 1112, 1230, 1399, $1403,1404,1407,1411,1485,1493,1496-1499$. $1508,1513,1514,1530,1531,1533,1537-1550$, $1553,1554,1559,1560,1573,1584-1591,1594$, $1595,1598,1599,1626,1644,1815-1871,1981$, 1987,1991

Honolulu Times, 1231

Hoogerwerff, J., 2727

Ka Hoolaha Manaoio, 1232

Hooper, Paul F., 1640

Hormann, Bernhard L., 1401, 1677

Horne, C. Silvester, 915

Horne, Shirley, 2687

Hosking, Richard J., 2594, 2823, 2923

Hostetler, Harold, 1649, 1947

Hosting and Purchasing, 60, 634, 635

Howell, Beatrice, 2004

Hoyt, Helen P., 1383, 2001

Hsin Chung Kuo Jih Pao, 1233, 1872-1876

Hugh, E. I., 2944

Hull, George C., 1651

Hulsen, Al, 1431

Hungerford, Brian, 2645

Hunnewell, James P., 1973

Hunt, James, 1112

Hunt, John, 759, 762

Hunter, Charles H., 1113, 1114, 1915

Hunter, Gene, 1637, 1955, 2092, 2181

Hunter, Pat, 457

Hwang, John C., 1447-1449

I Gaseta, 3024, 3104, 3107

Ibbotson, Peter, 2858

Ici Tahiti, 831, 903

Illustré de la Nouvelle Calédonie, 2336

IL WU Reporter, 1234 
L'Indépendant, 832

Independent, 1235

Independent New Guinea News Service, 2512

Inder, Stuart, 133, 136, 139, 2620, 2634, 2663

Indian Times, 678

Information Bulletin, 974, 1067

Informations, 2335

Inside Moresby, 2498

Inside New Guinea, 2498

International Bank for Reconstruction and Devel opment, 2546

International Longshoremen's and Warehousemen's Union (ILWU), 1402, 1561, 1618, 1805 1806,2022

International News Service, 1822

International Training Institute, 2591

International Typographical Union, 1528, 1555

Ioi Karanga, 463, 479

Island Broadcasting Co., 2251, 2253, 2261

The Islander, 1111, 1236

Itukutuku, 555

Jabulka, Jan, 1613

Jackson, Frances, 1969

Jackson, Keith, 2824

Jacoby, Alfred, 909

Jagriti, 556

Jai Fiji, 557

James, E. A., 2713, 2716, 2752

Japan, South Seas Bureau, 3065

Jardin, M. G., 1998

Jarves, James J., 1388, 1389

Jeffery, Peter, 2611, 2855

Jenkins, D. L., 14

Jitsugyō no Hawaii, 1237, 1896, 1897

John Hutton Corp., 2106

John Walton Enterprises, 2064

Johnson, Robert, 2289

Johnson, Rubellite K., 1115, 1116

Johnstone, Ian A., 208, 210, 273, 296

Jones, Bob, 1505, 1635, 1787, 1957, 2200

Jones, Kathleen, 1468

Le Journal Calédonien, 2344

Le Journal de Papeete, 833

Le Journal de Tahiti, 834, 902

Journal of the Pan-Pacific Research Institute, 1111

Journal Officiel de la Nouvelle-Calédonie et Dépendances, 2338

Journal Officiel de la Polynésie Française, 835

Journal Officiel du Territoire des Iles Wallis et Futuna, 3191

Journal Officiel: Gazette, 2390

JRAK, 3142, 3143

Julich, Reinhold W., 1997

Kagihara, Diane L., 1631

Kahn, E. J., Jr., 1022, 3097, 3098

Kahnert, Friedrich, 328

KAHU, 2045-2047

Ke Kahunaao, 1238

KAII-TV, 2269, 2270

Kaimuki Chronicle, 1363

Kaiser, Henry J., 2053, 2069, 2289-2292, 2294 2296
Kaiser Industries Corp., 2205, 2206

Kakamora Reporter, 2872, 2892, 2896, 2897

KALA-TV, 2268

Kaloni Kali Tonga, 2930

KALU-TV, 2268

Kanak, 2339

Kaser, Tom, 359, 360, 366, 386, 1951

Kashiwahara, Ken, 1503, 1948

$K a ' u$ News, 1240

Kauai Herald, 1211

Kawahara, Kimie, 1889

$\mathrm{KCCN}, 2048$

Keesing, Felix M., 3231

Kent, Graeme, 2883, 2884, 2887

KFOA-FM, 2029, 2106

KGMB, 2049-2058

KGMB-TV, 1459, 1463, 2231, 2234-2242, 22452248

KGTF, 1003-1005

KGU, 1386, 2018, 2032, 2059-2064

KHAI, 2065, 2066

KHAW-TV, 2269, 2270

KHBC, 2050-2053

KHBC-TV, 2242, 2244-2248

KHET-TV, 1447-1449, 1471, 1472, 1478, 1479

KHON, 1561

KHON-TV, 2269, 2270

KHPR, 1430

KHSS-FM, 2067

KHVH, 2053, 2068-2073

KHVH-TV, 2289-2298

KHVO-TV, 2298

Ke Kiai, 1242

Ke Kiai o ka Lahui, 1243

Kie, Kathleen A., 1523

Kieta News, 2499, 2689, 2690

KIKI, 2074, 2075

Ke Kilohana o ka Malamalama, 1244

Kim, Hyðn-gu (Henry C.), 1384

Kim, Hyung-chan, 1117

Kim, Wðn-yong (Warren Y.), 1902, 1903

Kimura, Yukiko, 1891

King, J. P., 382-389, 418, 429

King, Ron, 2074

King, Samuel P., 1589, 1590

King, Samuel W., 1455

Kingzett, Jim, 390, 391

Kinjo, Chinyei, 1929

KIPA, 2076

KISA, 2077, 2078

Kittelson, David, 1969, 2016

Kittermaster, A. M., 942, 2880

KITV, 2298

KJQR, 3154

KKUA, 2079

KLEI, 2080-2082

Klopf, Donald W., 2042-2044

Kluckhorn, Frank L., 2649

KMAU-TV, 2243, 2245-2248

KMVI-TV, 2299, 2300

Knowlton, Edgar C.. Jr., 1916, 1917

Ko E Bo'obo'oi, 2935, 2968

Ko E Kalonikali Tonga, 2930, 2948-2950, 2952 2954, 2958-2964, 2966, 2967, 2969-2973

Ko E Taimi o Tonga, 2931 
Ko Hawaii Pae Aina, 1308

Ko Hawaii Ponoi, 1246

Kohala Midget, 1288

$\mathrm{KOHO}, 2042$

K(O)KUA Radio One Corp., 2079

Kona Echo, 1248, 1898, 1899

Kona Star, 1249, 1900

Kona Times, 1250, 1582

Kona Torch, 1251, 1901

Kona Tribune-Herald, 1367

KONA-TV, 1463, 2255-2268, 2299

Ke Koo o Hawaii, 1315

Kook Min Bo, 1254, 1255, 1384

Korean National Herald, 1254, 1255

Korean Pacific Weekly, 1348, 1255

KORL, 2083, 2084

Kousurata, 2391, 2410-2412

KPOA, 2250, 2251, 2253

KPOI, 2085-2089, 2260

KPUA, 2090, 2091

KQED, 1434

Kroepelien, Bjarne, 917

KTOH, 1670

KTRG, 2092-2098

KTRG-TV, 1575-1577, 2271-2276

KTUH, 2099-2103

KUAI, 2104, 2105

KUAM, 1091, 1093, 1097-1099

Kucera, Geoffry, 1439, 1440

KULA, 2046, 2251, 2252, 2278-2283

KULA-TV, 2278, 2279, 2282-2285, 2287, 2288, 2294

Kulz, H. 3093

KUMU, 2106, 2107

Ke Kuтu Hawaii, 1259

Ke Kumu Kamalii, 1260

Kundu, 2500

Kurrus, Ted, 352

Kuu Hae Hawaii, 1261

KVZA, 3134

KVZK-TV, 336, 460, 3003

Kwazan, 1262

KZOO, 2042

Ka La o Hawaii, 1263

Lader, Lawrence, 182

Lae Courier, 2526

Lae Nius, 2502, 2691, 2692

LaForrest, James R., 3139

Lagasai, 2503, 2693

Lahaina Sun, 1287

Lahui Hawaii, 1265

Lai, Kum Pai, 1652

Ka Lama Hawaii, 1266

Lamb, David, 377

Lambeth, Harry J., 2021

Ka Lanakila, 1267

Langdon, Robert, 907

Lange, Fritz, 3094

Lau, Chau-Mun, 1118

Ka Lau Oliva, 1268

Launuat-Lagasai, 2505

Lawn, Victor H., 747

Lawrence, C. C., 2075

Leab, Daniel J., 1554
Lebasa, Biga, 2846

Lee, H. Rex, 351-353, 356, 361, 371

Lee, John, 107, 587

Leeward \& Wahiawa Sun Press, 1360

Leeward Sun Press, 1270

Ka Lei Momi, 1284

Ka Lei Rose o Hawaii, 1272

Ka Leialii o Hawaii, 1273

Lenk, John, 1901

Ka Leo o Hawaii, 1274

Ka Leo o Hilo, 1275

Ka Leo o ka Lahui, 1276

Ka Leo o Molokai, 1162, 1904

Ka Leoiki, 1275

Leonard, Hugh, 761

Lerg, Winfried B., 22

Lerner, Daniel, 70, 74

Lester, R. H., 707

Levi, Lavea, 77

Li, E, K., 1872

Li, Ling-ai, 1874, 1876

Liang, Ch'i-Ch'ao, 1872

Liang, William W. Y., 1656

Le Libéral, 827

The Liberal, 1279

Lind, Andrew W., 1484

Lindsley, L. N., 1060, 1063

Lingenfelter, Richard E., 166

Liston, J. W., 3303

Litch, Ernest W., 1006, 1008

Livesey, Cris, 15

Livingston, Fred, 2081

Lloyd, Tom, 2455, 2462, 2466

Loan Ebeye Rankin, 3025

Loan Ran Kein, 3026

Lockley, Fred, 1982

Ka Loea Kalaiaina, 1280

London Missionary Society, 914, 915, 917, 3211, 3305

Long, Dwight, 885

Long, Oren E., 1763

Loomis, Albertine, 1990, 2009, 2015

Loomis, Elisha, 1612, 1975, 1976, 1990, 1997, 1999, 2009

Lueras, Leonard, 1734, 2037

Lum, Arlene, 1860

OL uso, 1281

O Luso Hawaiiano, 1281

Lutheran Mission Printery, 2748

Lyle, Jack, 328, 1409, 1468

Lynch, Russ, 1500, 2196

MacDonald, Alexander, 1615

MacDonald, Barrie, 956

MacDonald, N. R., 108

MacKay, Ian K., 211, 2792, 2805, 2820, 2825, $2826,2829,2834,2835$

Mackintosh, Stephen D., 1383

Madison, Curt, 3241, 3331

Magisi, S. M., 2963

Maharaj, Ambika, 766

Mahutariki, Marii, 488

Majuro Times, 3027, 3108

Ka Makaainana, 1283, 1284

Makino, Fred Kenzaburō 1385, 1687, 1688 
Makino, Michiye (Mrs. Fred K.), 1686, 1690, 1693

Malaita News Letter, 2873

Malama-Foou, 3192

Malone, Michael, 3085

Ka Manawa, 1285

Mander-Jones, Phyllis, 16

Maneki, Ray, 2047

Mann, Bill, 1431

Mansfield, Norma, 604

Marianas Bulletin, 3028

Marianas Panorama, 3028

Marianas Variety \& News and Views, 3030, 3086, $3090,3104,3109,3110-3112$

Markle Foundation, 3074

Marshall, J. J., 17

Marshall Islands Journal, 3031, 3032

Marshall Islands Observer, 3033

Marzen, Francis, 1680

Masland, Grant, 346

Mason, George, 1909

Te Mata-ara, 837

Matas-Kelekele, Kalkot, 2413

Matsunaga, Spark, 1474, 1475, 1633

Te Mau Opuaraa . . . Te Mau Faaotiraa, 838

Maude, H. E., 18

Maui Community College, 1420

Maui News, 1286

Maui Publishing Co., 1528, 2299, 2300

Maui Sun, 1287

Mauna Loa Broadcasting Corp., 1900

Mayer, Phil, 1430, 2034, 2193

Mayo, Donald S., 1387

Mazellier, Philippe, 904

McBain Norman, 85, 593, 2595

McClelland, Robert S., 2952, 2964-2966, 2973

McClung, David C., 1514, 1948

McCoy Broadcasting Corp., 2270

McDonald, Louise, 1636

McElrath, Robert L., 1561

McGrath, Thomas B., 1094

McIntosh, K. C., 1016, 1025

McKinney, Albert J., 1399

McMechan, Peter, 786

McMillan, Michael E., 23, 113, 451

McNeil, John, 2422

Mead, Margaret, 69

Melanesian Mission Press, 2898-2900

Mellen, George, 1883

Meller, Norman, 628

Messager de Tahiti, 835, 840, 906

Met Poraus, 3034, 3115

Metcalfe, John R., 2915

Metro-Goldwyn-Mayer, 66, 2559

Metzger, Don, 2064

Micronesia Star, 3030, 3085

Micronesia Times, 3037

Micronesian Broadcasting Corp., 3148

Micronesian Braodcasting Service, 3149, 3151

Micronesian Free Press, 3038

Micronesian Independence Support Committee, 3039

Micronesian Independent, 3040, 3104, 3115, 3116

Micronesian Monthly, 3043, 3117

Micronesian National Communication Network, Ltd., 3164
Micronesian News Service, 3042, 3092

Micronesian Reporter, 3004, 3043, 3117

Micronitor, 3040, 3115, 3116

Micronitor News and Publishing Co., 3018, 3032, 3114

Micro Scope, 3035

Mid-Pacific, 1111, 1289, 1640

Middlemiss, Barry, 2678

Middlesworth, Mike, 1869

Midget, 1288

Mihalic, Francis, 2780

Miki, William, 2920

Military Sun Press, 1192

Mills, J. Saxon, 102

Milz, Barbara, 1789

Min Sheng Daily News, 1658

Mink, Patsy T., 249

Misko, Carol, 254, 270

Missionary Review, 117

Mitchell Library, 19

Moffatt, Tom, 2085

Mogethin, 3048

Molokai Reporter, 1291, 1905

Ka Momi o Hawaii, 1292

Le Monde Pour Tous, 841, 900

Le Moniteur de la Nouvelle-Calédonie, 2338

Le Moniteur Impérial de la Nouvelle-Calédonie et Dépendances, 2338

The Monitor, 1293

Mookini, Esther K., 1119, 1732

Morea, John, 2584

Moresby Army News Sheet, 2507, 2699

Morita, Sakae, 1879

Morning Guide, 1149

Morning Star, 982

Morobe News, 2506, 2694-2698

Morris, Aldyth V., 1488

Morris, R. J., 2573

Morrissey, Penny, 2214

Morrow, Monte, 1702, 1704

Morse, Harold, 780

Moses, Charles, 207

Mosogo, E., 2573

Moss, Frederick J., 463

Mott, Frank L., 1737

Moule, H. F., 164

Moulik, Rita, 2574

Mouton, Jean Baptiste Octave, 2727

Muir, T., 511

Mulrony, M. A., 2019

Municipal Record, 1295

Murphy, Joe, 1074

Murrant, Jim, 676

Murray, J. K., 2664

Mutual Telephone Co., 2160, 2280

Na Mata, 559

Na Tovata, 541

Nabanga, 2392

Ka Na'i Aupuni, 1296

Nai Lalakai, 558, 679

Nakano, Suyeo, 1881

Nakasone, Henry I., 1402

Namposhi Kenkyúkai, 3005

Nand, G. R., 617 
Nanyō Mainichi Shimbun, 3049

Nanyō Shimpo, 3050

Nasonal Pati Nius, 2393

National Aeronautics and Space Administration (NASA), 216, 219, 222, 249

National Association of Educational Broadcasters, 343, 344, 367-370

National Association of Radio and Television Broadcasters, 2160

National Broadcasting Co., 2860

National Education Association, 1002

National Herald, 1297

National Labor Relations Board, 1525, 1526, 1533,2107

Nauru Government Gazette, 2310

Nauru News, 2304

Nauru Times, 2311, 2315

Nauruan Scouter, 2314

Naylor, Malcolm, 2815

Negus, Christine, 289

Nelson, H., 2719

Nelson, Lyle, 330, 1473

Nelson, O. F., 3271-3273

Le Néo-Hébridais: Journal Français Indépendant, Politique, Agricole et Commercial, 2394, 2405, 2413

Netram, Salma, 3326

New China Daily News, 1233, 1872-1876

New Era and Weekly Argus, 1299

New Guinea and Australia, the Pacific and Southeast Asia, 52

New Guinea Courier, 2700, 2701

New Guinea Highlands Bulletin, 2509

New Guinea Times-Courier, 2526, 2701-2704

New Hebridean Viewpoints, 2395, 2408

New Hebrides British Service Gazette, 2396

New Hebrides Broadcasting Service, 2421-2424

New Hebrides Nakamal, 2391, 2408

New Hebrides News, 2398, 2409

New Pacific, 1300

New Zealand, Broadcasting Commission, 87, 206 , 2592, 3312; Department of Island Territories, 469, 3223; University, 14

New Zealand Herald, 108

New Zealand Samoa Guardian, 3207, 3248, 3264, 3271-3273

Newbury, Colin W., 906

Newell, Ray, 2582

Newport, Tuck, 1512, 1513, 1645

News and Views, 561, 680

News and Views Bulletin, 304, 421

News Bulletin (American Samoa), 302, 322, 381, 398

News Bulletin (Nauru), 2304

News from Fiji, 540

News from the Gilbert and Ellice Islands Colony, 932

News Review: Papua-New Guinea, 2512

Newsbeat, 2511

Ni Bula Mai, 539

Nichols, Oscar, 1397, 1398

Nieuw Guinea Studien, 2513

Nilaidat, 2514

9PA, 2757-2759, 2762, 2766, 2767, 2769, 2777

Nipon Shuho, 1711
Nippon Hơso Kyőkai (NHK), 2939, 3002, 3142, 3143

Nippu Jiji, 1202, 1399, 1525, 1526, 1712-1714

Nisei, 1111

Niu Vakai, 2932

Niue Island Gazette, 2427

Niue Newsletter, 2428

Nius Bilong Yumi, 2515

Nius Long Gavman Bilong Australia, 2484

Nixon, Raymond B., 2624

Noble, Grant, 2584

Ka Nonanona, 1302, 1906

Norfolk Island Gazette, 2445

Norfolk Island Government Gazette, 2445

Norfolk Island Monthly News, 2455

Norfolk Island News, 2447, 2448, 2465

Norfolk Island News Edition, 2455, 2460

Norfolk Island Notices and News, 2455, 2461

Norfolk Island Pioneer, 2451

Norfolk Island Times, 2455, 2458, 2459

Norfolk Island Weekly, 2455, 2459, 2460

Norfolk Island Weekly News, 2455, 2457

The Norfolk Islander, 2455, 2462, 2463, 2466

Norfolk News, 2455, 2462, 2463

Norfolk Newsletter, 2456, 2464

Norris, Stephen S., 1407

Northcott, Dick, 786

Northrup, John, 428

Nose, Katashi, 220, 225, 237

Noumea Beach Press, 2342

Noumea Holiday, 2357

Noumea-Soir, 2345

Nouveau Journal Calédonien, 2344

Les Nouvelles, 842

Les Nouvelles Calédoniennes, 2345, 2360

Nouvelles Tahitiennes, 843, 844, 899

Nu Gini Toktok, 2517, 2572, 2705, 2706

Ka Nuhou, 1303, 1304

Ka Nuhou Hawaii, 1303

Ka Nupepa Aloha Aina, 1130

Ka Nupepa ka Oiaio, 1307

Ka Nupepa Kuokoa, 1308, 1907, 1908

Ka Nupepa Kuokoa Puka La, 1309

Ka Nupepa La Ko Hawaii Pae Aina, 1313

Ka Nupepa Poakolu, 1273

Ka Nupepa Puka La Aloha Aina, 1130

Ka Nupepa Puka La Kuokoa Me Ko Hawaii Pae Aina I Huila, 1313

O Le Fa'atonu, 302, 395

O Le Savali, 3216, 3264, 3300, 3301

O Le Sulu Samoa, 3201

O Sala Ususur, 2898

Oceania, 118

Oceania Daily News, 564, 681, 682

Oceanic Cablevision, Inc., 2213, 2222-2224

L'Océanie Française, 845, 846, 913

L'Océanie Française: Bulletin Mensuel du Comité de L'Océanie Française, 847

O'Connor, Owen, 15

Official and Commercial Record, 1314

Ke Ola o Hawaii (Hilo), 1316

Ke Ola o Hawaii (Honolulu), 1315

Oliver, Douglas L., 3066

Olkowski, Dennis A., 586, 773 
O'Reilly, Patrick, 63, 64, 694, 801-803, 905, 2321, 2383,3193

Organe du Liaison du Rassemblement, 808

Organe du Rassemblement, 808

O'Sullivan, Sherry, 442, 443, 445

Our News, 2515, 2583, 2707

Outrigger, 3051

Pacific American, 119, 120

Pacific and Southern Broadcasting Co., 2269, 2270

Pacific Broadcasting Co., 2296

Pacific Business News, 1317, 1909

Pacific Commercial Advertiser, 1225, 1380, 1386, 1390, 1739-1743

Pacific Courier, 1319

Pacific Daily, Ltd., 625

Pacific Daily News, 983, 1000, 1070, 1072-1075, 3118-3120

Pacific Daily News Service, 1601

Pacific Dateline, 984, 998, 1000, 1070, 1072-1075, 3118-3120

Pacific Features \& Sports, 1111, 1300

Pacific Frontier Broadcasting Co., 2251, 2282, 2284, 2287

Pacific Islands Communication Newsletter, 53, 121-127

Pacific Islands News Association, 53, 88, 127, 143-158, 599

Pacific Islands Trade News, 55

Pacific Journal, 985

Pacific Manuscripts Bureau, 21

Pacific Network, Inc., 2297

Pacific Press, Inc., 1070

Pacific Profile, 986

Pacific Publications Printing, Ltd., 135, 657, 663

Pacific Review, 565, 683

Pacific Science, 1111

Pacific Star, 3203, 3234, 3274

Pacific Sunday News, 983

Pacific Travel News, 56

Pacific Voice, 988

Pacific Weekender, 549

Pago Beach Press, 305

Palau Community Action Agency, 3017

Palau News, 3052

Palau Post, 3053

Pali Press, 1370, 1699, 1701, 1703

Palu, 'Uliti, 2994

Pan Pacific, 1111, 1289

Pan-Pacific Union, 160, 1640

Pang, Loretta O. Q., 1659

Pangelinan, Victor, 3107,3110

Pangu Pati News, 2708

Paper Nautilus, 2474, 2475

Papua and New Guinea Agricultural Gazette, 2525, 2709

Papua and New Guinea Agricultural Journal, 2525, 2710

Papua and New Guinea Gazette, 2521

Papua and New Guinea News, 2522

Papua and New Guinea Newsletter, 2523

Papua and New Guinea Villager, 2524

Papua New Guinea, Administrative College, 2476; Broadcasting Authority, 2547-2557; Communi- cation Coordination Committee, 2644, 2645, 2647; Department of District Adiministration, 2789; Department of Education, 2685; Department of Information and Extension Services, $2496,2515,2532,2573-2575,2577,2579,2586$, 2589, 2643, 2646; District Administration Broadcasting System, 2792, 2793, 2795, 28002802, 2805, 2808-2811, 2816-2819, 2822, 2834; Government Printing Office, 2750; Minister of Information, 2547-2557; National Broadcasting Commission, 2541, 2581, 2582, 2591, 2598, $2630,2813,2823,2824,2827,2829,2831,2832$, $2834,2835,2838,2840,2841,2844$; University, $2477,2596,2600,2601,2855$

Papua New Guinea Post-Courier, 2526, 26252627, 2711, 2712

Papuan Courier, 2527, 2614, 2673, 2713-2716, 2751, 2752

Papuan Times, 2528, 2718

Papuan Times and Tropical Advertiser, 2527, 2673, 2717

Papuan Villager, 2530, 2673, 2719, 2720

Paradise Magazine, 1323, 1910

Paradise of the Pacific, 1111, 1224, 1737

Park, Robert E., 1120

Parker, Edwin B., 1468

Patterson, Wayne K., 1117

Paul, E. F., 3303

PEACESAT (Pan Pacific Education and Communication Experiments by Satellite), 74, 80, $84,96,97,218-294,457,458,513,514,516$, $517,774,775,777-779,783,788,928,1095$, $1096,2111,2112,2114-2116,2119,2120,2124$, $2125,2127,2132,2133,2135,2137,2140-2142$, $2147,2373,2374,2425,2426,2442,2845-2848$, $3155-3161$

Peat, Neville, 2971

Peck, D. G., 746

Pelzer, Karl J., 3064

Pence, Martin, 1600

Périodique d'Information Publié par le Rassemblement, 808

Pernetta, Mary, 772

Le Petit Tahitien, 846

Les Petite Announces, 849

Les Petites Affiches de Tahiti, 850

Philippine-American Press, 1326, 1911-1913

Pidgin English News, 2517

PIM (Pacific Islands Monthly), 54, 128-139

Piniau, Sam, 2827

Pinnacle Press, 2312

Pisin Pepa, 2721

Pitcairn Island Miscellany, 2856-2858

Pitt, David, 3232

Plantation Health Bulletin, 1111

Platt, William J., 3079, 3080

PNG Newsletter, 2532

Polcyn, Kenneth A., 236

The Polynesian, 1327, 1388, 1389, 1757, 1914

Polynésie Française, 851

Ponape Community Action Agency, 3056

Ponape-per, 3054, 3121

Poo, Anna, 2574

O Popular, 1328

Poroi, Alfred, 904 
Port Moresby Teachers' College, 2855

Porter, David, 2995

Povai, 567, 684

Prakke, Henk, 22

Pratte, Paul A., 1491, 1848, 1849, 1870

Press Congress of the World (Hawaii), 159-162, 1931-1938

La Presse de Tahiti, 819, 852, 903, 904

Preview, 2874

Pua Mana, 1918

Public Opinion Bulletin, 304

Pukui, Mary K., 1731, 1732

Ka Puuhonua o Na Hawaii, 1329

Qalo, L. S., 523

Quigg, Philip W., 3100

\section{Rabaul Gazette, 2494}

Rabaul News, 2534, 2722, 2723

Rabaul Record, 2535, 2673

Rabaul Times, 2479-2481, 2526, 2673, 2705, 2724-2732

Radio Australia, 188, 200, 2468, 2469

Radio Honolulu, Ltd., 2251, 2252, 2254-2259, $2261,2268,2282$

Radio KHAI, Inc., 2065

Radio New Zealand, 183, 185, 189, 190, 195, 213, 214, 500, 503

Radio Preview, 568

Rai Review, 3055

Ramepa Api, 853

Ramsey, John, 1909

Rangatan, Christian, 2585, 2831

Rankin, Bob, 3293

Rankin, R. F., 337, 3245, 3246, 3329

Raraka, Henry, 2892, 2897

Read, John, 1679

Reed, Judith, 1733

Reed, Robert M., 1452

Reef, 854

Reeves, Earl, 1958

Regenvanu, Sethy, 2403

Reinecke, John E., 1812

Reitman, Edouard, 802

Te Repositori, 855, 913

Le Réveil, 856

Réveil Canaque, 2346, 2360

Reynolds, Donald W., 1727, 1728, 1730

Richard, Dorothy E., 3096

Richstad, Jim A., 23, 74, 113, 146, 237, 278, 458, $1414,1490,1494,1523,1952,1964,1965,1967$. 1968,2896

Rider, Richard, 2821

Rigu Karamut, 2733

Rivers, William L., 1956, 1958

The Roach, 1178, 1682

Robert Dollar Co., 1083, 1085

Roberts, Quincy F., 446

Robertson, Patricia, 2618, 2619, 2621

Robson, R. W., 129, 131, 132, 137, 610, 618, 619 , $621,656,2354,2615,2616$

Rodriguez, Virgilio B, , 1933

Rongo, 58, 140

Rosario, Francisco S., 3089

Rose, A. H. T., 3314
Rose, D. W., 1729

Rosen, Leon, 279

Rousseau, Helen, 2360

Royal Broadcasting Co., 2065

Royal Gazette, 3205

Royal Hawaiian Radio, Inc., 2106

RoyalTel, 2252, 2284-2286

Roycroft, Allen, 2034

Ryan, John, 2626, 2627, 2708

Sacred Heart Cathedral Gazette, 569

Saiki, Patsy S., 1211

Sail Ho, 685, 946

Saito, Shiro, 1122

Sakamaki, Shunzo, 1882

Sakamoto, Lawrence, 1694

Sales Builder, 1111, 1331

Salisbury, Richard F., 2806

Samaa Bulletin, 438, 439, 3210, 3250, 3259-3261, $3264,3278-3285,3288$

Samoa Guardian, 3207, 3264, 3270

Samoa Herald, 3208, 3275, 3276

Samoa Islands Monthly Journal, 307

Samoa News, 308, 309, 382-389, 422-430

Samoa Scene, 300

Samoa Times, 311, 437-441, 3209, 3210, 3234, $3253,3257,3264,3277,3284-3289$

Samoan Broadcasting Service, 3320, 3326

Samoan Information Bulletin, 395

Samoan Reporter, 3211

Samoan Sun, 312, 431-436

Samoana, 3195, 3250, 3251, 3260, 3261, 32903297

Samoana-Herald, 3213, 3258, 3298, 3299

Samoanische Zeitung, 3209

Samoanisches Gouvernments-Blatt, 3215

Sandwich Islands Gazette and Journal of Commerce, 1333, 1919, 1920

Sandwich Islands Mirror and Commercial Gazette, 1333

Sandwich Islands Monthly Magazine, 1334, 1921

Sandwich Islands News, 1335

Sapias, Austin, 2670, 2672

Sato, Jessie J., 1441

Satō, Katsuzō, 3142

Saturday Press, 1149

Savali, 3216, 3264, 3300, 3301

Sawyer, Beryl, 890, 891

Schmitt, Robert C., 1394, 1395, 2013

Schmolke, Michael, 22

Schneider, Emil A., 2188

Schramm, Wilbur, 327, 334, 335, 1468

Schutrumpf, E. D., 172

Schwartz, Richard, 2962

Schwimmer, Z., 2797

Scott, John A., 1861

Scott, Robert L., 1968

Scripps League' Newspapers, 1670, 1697, 1698 , 1701

Searles, P. J., 1046

Selle, Earl A., 2116

Senda, Warren, 378, 2217

The Sentinel, 3195

A Sentinella, 1281

Senyavin Times, 3056, 3121 
Servir, 881

A Setta, 1338

Seumahu, E. S., 259

Sexton, Marion, 1926

Shanti Dut, 570, 686

Sheldon, H. L., 1604

Sherman, Charles E., 142

Shimin, 1339, 1662, 1897

Shipwreck, 3022

Shōgyō Jihō, 1340

Shäkan Times, 1341

Si Togi, 859

Silva, Ernest, 2040

Simpich, Frederick, Jr., 1634

Simpungun, Chuuk, 3058

Sinclair, Gregg, 1465

Sitaram, K. S., 1477

Sizer, Theodore, 1388

Skornia, H. J., 344

Smales, Gus, 2642

Smith, Dan, 1003, 1004, 3072, 3153

Smith, Delbert D., 2124

Smith, Joseph, 1456

Smith, Lawrence R., 1994

Smith, W. G., 1743

Smyser, A. A., 1628, 1959

Snow, Edward C., 897

Sōga, Yasutarō, 1387, 1709-1711, 1715

Solomon Islands Broadcasting Service, 2885, 2917, 2920, 2922-2924

Solomon Islands Gazette, 2875

Solomon Islands Information and Broadcasting Services, 2893, 2895

Solomon News Drum, 2876, 2893-2895

Somare, Michael, 2671, 2832, 2839

Sorensen, Philip H., 3079, 3080

Le Sourire, 858, 900

South Pacific, 59

South Pacific, University of, 46, 224, 228, 252 $253,527,599,779,784,786-788,2425,2864$, 2999

South Pacific Action Network, 62

South Pacific Area News Service, 622

South Pacific Bulletin, 61

South Pacific Commission, 8, 24-28, 61, 85, 91, $93,95,192,205,208,210,212,285,296,784$, 1096, 2593, 3243

South Pacific Islands Business News, 60, 141

South Pacific Post, 2526, 2701, 2734-2739

South Pacific Post, Ltd., 2735, 2739

South Sea Star, 3218, 3298

South Seas Weekly, 571

Southern California, University of, 370

Spaulding, Thomas M., 2003

The Spokesman, 1342

Spooner, R. G., 2442

Stannage, John S., 736, 741

Star of the Pacific, 687

Starck, Kenneth, 1958

Starr Broadcasting Group, 2298

Steegmuller, Francis, 1389

Stenberg, Ernest W., 1985

Stephen, David, 2667

Stevens, Russell L., 1011

Stolz, Jack H., 340
Storm, Birch, 1892

Strange, Jerry D., 235

Sud Pacific, 2347

Sullam, Brian, 1397, 1398, 1508, 1520

The Sun, 1349

Sunday News, 572

Sunday Sun, 645, 649

Sunday Volcano, 1346

Suria, Sivia F., 422

Survey and Marketing Services, Inc., 1413, 14151417

Suva Times, 549

T'aep'yorngyang Chapchi, 1348

T'aep'yongyang Chubo, 1348

Tahiti Bulletin, 861, 909

Tahiti-France, 870

Tahiti, Les Nouveaux Objectifs, 863

Tahiti Magazine, 864, 903

Tahiti News and General Advertiser, 865

Tahiti Radio Club, 919-921

Tahiti Tourist Guide, 866, 867

Le Tahitien, 868, 869

Taillemite, Etienne, 804

Taiyō, 1349

Takeuchi, Floyd, 380, 2747, 3070, 3078, 3087, 3161

Tala o Tuvalu, 3172

Tala Samoa, 308

A Talanoa, 688

Tamarii Tahiti, 852

Tamashiro, John G., 1411

Tamilang, 3059

Tashima, Takumi, 1868

To Tatou Aveia, 880

Taumua Lelei, 2933

Taureka, Reuben, 2842, 2843

Tax Foundation of Hawaii, 1446

Taylor, Clarice, 1986

Taylor, Desmond M., 752, 753

Tea Vea o Te Hau No Tahiti, 871

Tedder, James L. O., 2595, 2921, 2922

Teissier, Raoul, 803

Teitei, 948

Tekaai, Timai, 148

Tenbruggencate, Jan, 1504

Tero, 939

Territorial Agencies, Ltd., 2154

Territorial Council on Educational Television, 1462,1942

Territorial Sun, 989, 1070

Territorial Surveys, 1400

Territory of Papua Government Gazette, 2521

This Month in Guam, 990

Thomas, Ralph, 2174

Thomas, E. L. Gordon, 2479-2481, 2558, 2697, 2705, 2727, 2730, 2731

Thomas, Elias H., 3078, 3150, 3154

Thomas, Graham, 3240

Thomas, William H., 338

Thompson, R., 75

Thompson, Virginia, 908

Thornton, Jack, 471, 618-621, 3322

3LO, 168

Thrum, Thomas G., 1742, 1931, 1932 
Thurston, Lorrin A., 416, 1386, 1390

Thurston, Lorrin P., 1567-1569, 1571, 1572, 1746, $1749,1779,1811$

Tia Belau, 3060, 3104, 3122, 3123

Te Tiarama No Te Mau Fenua Tahiti, 872

The Time, 1350

Today's News, 1203

Toganivalu, David, 112,616

Tohi Tala Niue, 2429, 2435

Tolai News, 2740, 2741

Toner, Tim, 1586, 1589

Tonga Broadcasting Commission, 2947, 29762983, 2988, 2991-2995, 2997, 2998

Tonga Chronicle, 2934, 2943, 2948-2950, 29522954, 2958-2964, 2966, 2967, 2969-2973

Tonga Government Gazette, 2935

Tongan Daily News, 2936, 2956

Tongan Times, 2931, 2937

Torch, 2742

Torea (Papeete), 873

Te Torea (Cook Islands), 463, 479, 489

Torokina Times, 2890

Torres Straits and New Guinea Gazette, 2540, 2743

Toua, Morea, 2831

Toyama, Tetsuo, 1662, 1897

Transmitter, 2541

La Tribune de Tahiti, 874

La Tribune Tahitienne, 875

Tropic Topics, 1352

Truk Review, 3061

Truk Tide, 3034

Trumbull, Robert, 111

Truth, 1353

Tsutsumi, Fred, 1814

Tudor, Judy, 30, 138, 632, 680

Tuimavave, Tumele, 3255, 3256

Turnbull, Phyllis, 31

Turner, Charles, 1632, 2296

Tusitala Samoa, 3210

Tuvalu Broadcasting and Information Service, 3187

Tuvalu News Sheet, 3174

TV\& Entertainment Week, 991

TV Guam, 992

Twain, Mark, 1616

Twigg-Smith, Thurston, 1536, 1567-1569, 1772

$2 \mathrm{AP}, 3252,3253,3310,3312-3314,3316-3320$, $3322,3326,3327$

Tzu Yu Hsia Pao, 1658

Uherbelau, Victorio, 3084

Uludong, F. T., 3085

Umatuna Si Yuus, 988

Underground Monthly, 314, 442-445

Underground Press, 314

Unesco, 32-39, 85, 101, 2595, 2597, 2844, 3240, 3241

Uni Tavur, 2542

A Uniao Lusitana-Hawaiiana, 1281

Union, 876

Union Internationale de Radio-Diffusion, 175

Union Multiraciale de Nouvelle Calédonie, 2346

Union Progressiste Multiraciale, 2323

L'Union Tahitienne, 877
L'Unite, 2348, 2363

United Chinese Press, 1139

United Japanese Society of Hawaii, 1893, 1895

United News, 2543

United Press International, 1602, 1637, 1816

United States, Department of State, 319, 3067; House Committee on Un-American Activities, 1797-1799, 1803; Library of Congress, 40-44; Navy Department, 3006-3010, 3067, 3069, 3096; Senate Committee on Interior and Insular Affairs, 320; Senate Committee on the Judiciary, 2022; Senate Internal Security Subcommittee, 1804; Trust Territory of the Pacific Islands, $3011-3013,3019,3023,3028,3043,3055,3067$, $3068,3081,3145,3147,3150,3151,3153,3154$

United States Commercial Company, 3064, 3066, 3069

UPW Organizer, 1922

Usher, Leonard G., 114, 149, 153, 155, 157, 284, $659,664,671,787$

Va'a, Felise, 379, 3254-3256, 3269

Vakalelewa Ni Pasifika, 565

Valo, 940

Van Til, William, 349

Vanua, 575

Te Vea Maohi, 878

Te Vea No Tahiti, 840, 879

Vérités, 881

VICSAT (Village Communication Satellite), 2848

Victory, 1211

VL8VD, 2788

VL9BR, 2789

VL9CD, 2783, 2786

VLT, 2766

VL2NI, 2469

Voice of Labor, 1358

Voice of the ILWU, 1357

La Voix de Papeete, 825

La Voix de Tahiti, 880

La Voix du Cagou, 2349, 2361

Volagauna, 576, 689, 690

Voutas, A. C., 2666

VQO, 2909, 2910

Le Vrai, 884

VRH, 727

VTW, 952

Vusoniwailala, Lasarusa, 209, 598, 631, 800

Wahiawa Sun Press, 1360

Waikiki Beach Press, 1361

Waikiki Chronicle, 1363

Waikiki-Kaimuki Chronicle, 1363, 1923

Wakukawa, Ernest K., 1712

Wall, Colman C., 677

Wallace, Paul J., 2684

Wantok, 2544, 2744-2746

Waqa, Luke, 612

Ward, Jim, 430

Ward, Marion W., 2640

Ware, Charles, 1793, 1794

Watts, Frank, 594

Watumull, David, 1575

Watumull Broadcasting Co., 2275

Wayagui, 2350 
Weekender, 468, 493, 494

Weekly Argus, 1299

Weekly Guardian, 564, 636-639, 681

Weekly Island News, 2455

Weekly Newsletter (Apia), 3220

Weekly Newsletter (Suva), 578

Weekly Roundup of News in Pictures, 491, 492

Weekly Times, 1341

Weinberg, Daniel E., 1408

Weiss, David, 1978

Wellington Polytechnic Institute, 87, 221, 226, $227,241,255,516$

Wendt, Sue, 2990

Wernet, Bob, 1502, 1860

West Hawaii News, 1366, 1924, 1925

West Hawaii Today, 1367

West Hawaiian Cable Vision, Ltd. 2220

Western District News, 2877

Western Herald, 549, 691

Western Pacific Herald, 549

Western Pacific High Commission Gazette, 581

Western Samoa Gazette, 3221

Western Samoa Mail, 3222, 3264, 3302, 3303

Western Telestations, Inc., 2070

Westervelt, W. D., 1974, 1975

White, Margaret, 252

Whitney, Henry M., 1380, 1382, 1605, 1739, 1742, 2000

Wiegand, John A., 336

Wilcox, Dennis L., 528, 2819

Wilcox, Paul, 2027

Wilkie and Co., 135

Williams, D. R., 2580

Williams, George, 758, 771

Williams, J. Grenfell, 90

Williams, Walter, 162, 1932, 1937

Windley, Larry, 2006, 2007

Windward Oahu Reporter, 1368, 1566, 1926-1928

Windward Press, 1369

Windward Publishing Co., 1663, 1664
Windward Sun Press, 1370

The Windword, 1371

Wireless Institute of Australia, 2849

Wise, C. M., 1995

Withers, W. Russell, Jr., 2046

Wolf, G., 47

Wolfe, George, 2173

Wolfers, Edward P., 2576

Wood, Donald N., 1439, 1451, 1453, 1454

Woodworth, Steve, 3078

Woolford, Don, 2673, 2833

Worldwide Publishing Co., 1647

Wright, Carl, 1664, 2216

Wright, Glen, 115

Wright, Theon, 1626

WSZA, 3138

WSZE-TV, 3165, 3166

WSZO, 3128, 3130, 3133, 3135, 3139, 3144, 3153

WVUV, 324, 448, 450-456

WVTV, 2302

WXLB, 3127

Wymer, Lubomyr, R., 1127

Yamato, 1202, 1711

Yamato Shinbun, 1202

Yank, 6

Yim, Evelyn, 3099

Yōen Jihō, 1374, 1929

Young, Susan, 2807

Young Micronesian, 3063, 3124

Youngblood, Ron, 2030

Yu, Arthur Y. C., 1410

Yuen, Paul C., 237

Yzendoorn, Reginald, 1919, 1979

Zalburg, Sanford, 1790

ZCO, 2947, 2976-2983, 2985, 2986

Zilen, Elizabeth, 338

ZJV, 701-704, 707, 715, 716 


\section{出 Production Notes}

This book was designed by Roger J. Eggers and typeset on the Unified Composing System by the design and production staff of The University Press of Hawaii.

The text and display typeface is English Times.

Offset presswork and binding was done by Halliday Lithograph. Text paper is Glatfelter P \& S Offset, basis 55 . 